UNIVERSIDADE DE SAO PAULO

\title{
O REAL E O IMAGINÁRIO NO BEXIGA: AUTOFAGIA E RENOVAÇÃO URBANA NO BAIRRO
}

\author{
FRANCISCO CAPUANO SCARLATO
}

Defesa de Tese para o titulo de Doutor, epresentada no Feculdade de Filosofia, Ciencies e Letros de USP Departamento de Geografia.

Orientador: Prof. Dr. Menoel Fernando Gongalves Seabra. 
Para você, querida irmā Egya, dedico este meu trabalho. Estou certo que a morte não será capaz de arrefecer 0 meu amor fraterno. 
1 PARTE

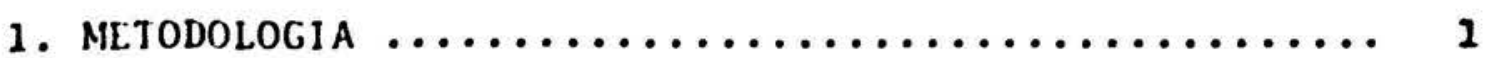

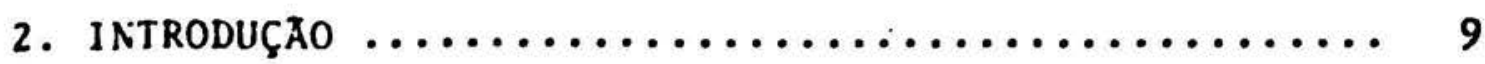

II PARTE

3. EVOLUÇAOO E AUTOFAGIA dO BEXIGA .............. 23

3.1. Dos Primórdios à Primeira Metade do Século XX. 36.

3.2. Bexiga - "Ano Zero" ................. 78

3.2.1. Tendências atuais nas formas de uso

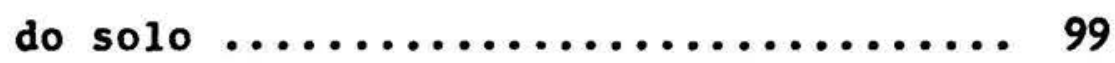

3.2.2. Em busca de um perfil demogräfico ..... 122

3.. 4 Unidade Quebrada ................... 130

3.3.1. Sobrevivências e mistificaçōes:

uma ideologia do "Bixlga" .......... 152

\section{PARTE}

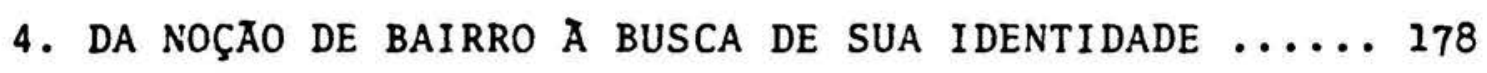
4.1. Unidade e Diversidade ................ 193 4.1.1. Estrutura e morfologia urbana ....... 197

IV PARTE

5. AS PROPOSTAS DE RENOVAÇÃO URBANA PARA 0 BAIRRO DO BEXIGA. 
Quero deixar, aqui, meus agradecimentos $\grave{a}-$ quelas pessoas que permitiram que este trabalho se concretizasse. Sem a preocupação de seguir uma sequência por ordem de importância, quero deixar minha memória seguir seu livre fluxo.

Ao companheiro, amigo e orientador, profes sor Manoel Seabra cuja presença e personalidade marcante , pessoa sempre comprometida com a seriedade do trabalho, es teja este no nível que estiver, quero expressar minha gratidão e respeito pelo seu trabalho como orientador, pela maneira segura e criteriosa como conduziu a realização des te nosso trabalho.

Aos amigos, Antonio Sampaio e Marina de Sampaio Goes, que gentilmente colaboraram na realização da primeira cobertura fotográfica do bairro do Bexiga, sem a qual nāo teríamos podido cumprir verdadeiramente uma das etapas do trabalho e a Sueli Angelo que nos permitiu entrar em contato com pessoas e instituições, fundamentais para nossa coleta de dados, meus agradecimentos.

Ao companheiro e amigo Nelson De La Corte, que com muita diligência realizou a cobertura fotogräfica que acompanha a presente tese, mais do que fotógrafo, foi ele, o companheiro, o geógrafo com o qual compartilhei observaçōes e anālises sobre a realidade do Bexiga durante nossas caminhadas pelo mesmo, fica aqui, a este grande ami go, meus sinceros agradecimentos. 
Nos colegas e amigos do lepartamento de Geografia, que de uma forma ou outra, através de uma palavra amiga me encorajaram para o término da presente tese, meus agradecimentos. Gostaria de expressar um agradecimento especial às colegas do Departamento, Ana Fani e Amélia, que num determinado momento de grande dificuldade colabora ram comigo no cumprimento de algumas tarefas de minha responsabilidade, estendendo-se o mesmo à Prof. Maria Elena R. Simielli.

A professora Marcia Gallo que gentilmente fez a revisão do presente texto e a Orita, que realizou com muita paciência os desenhos que acompanham o trabalho, meus sinceros agradecimentos.

Para minha mulher Eunice e às minhas fiThas, Tanieska, Karina e Alessandra, meus agradecimentos pela tolerância com que acompanharam a realização deste trabalho, quando então, roubei-lhes atenção e carinho.

Finalmente, aos membros da comunidade do Bexiga, cujos depoimentos estão aqui contidos e àqueles que ficaram no anonimato, fica mais uma vez expresso meus agradecimentos. 
I PARTE 
sa pesquisa, que vai aí relacionada:

1. NMHA MARZOLA - Bela Vista. DPli-PMSP, 2ă I.dição 1985.

2. Cela toledo luCenA - Bixiga, Amote Mio. Editora Pannartz. 1. Ed.. 198 , S. Paulo.

3. Idem, Bairro do Bexiga. A sobrevivencia cultural. Brasiliense. 19 , S. Paulo.

4. Haim Grunspun - Anatomia de um bairro. Livraria Ed. Cultura, 1. Ed., 1979, S. Paulo.

Com exceção da ûltima, as demais demonstram uma cuidadosa pesquisa bibliográfica de natureza historio gräfica. Aquela ủltima se apresenta mais como um livro de memórias vividas pelo autor no bairro, sendo também de gran de valia documental para o trabalho. Como obra inédita, con seguimos a pesquisa feita em 1985 pela IGEPAC (Inventārio Geral do Patrimônio Ambiental, Cultura e Urbano de S. Pau10). Secretaria Municipal da Cultura - DPH, sobre o títuloBela Vista. Esta obra pode ser considerada até então, uma das mais atualizadas feitas sobre o bairro da Bela Vista, a pós aqueles estudos feitos pela COGEP-PMSP no período de 1973/1974. Estes estudos apareceram no interior de Planos Diretores feitos sobre o bairro da Bela Vista com o seguinte titulo: PR-016, Bela Vista - 28-010, constituindo um con junto de sete volumes. Foi baseado nestes estudos que a COGEP-PMSP elaborou os dois projetos de urbanizaçāo para o bairro, assim intitulados: PR-016 - Grota da Bela Vista e Dossiê 038-2 - Projeto 13 de Maio, ambos no ano de 1975. Co mo $j a ̄$ assinalamos, o material veiculado pela imprensa em geral serviu-nos ao mesmo tempo de literatura crítica como também fonte primária da pesquisa. No momento que trabalhamos especificamente o universo do imaginārio, tivemos nesta última fonte um importante instrumento que nos permitiu a 
captaçōo do unjerso jdeológico que passa pelos discursos sobre o Bexiga.

Concluida esta parte dos estudos, procuramos elaborar as referentes às fontes primárias propriamente ditas, quando então estabelecemos a seguinte sequência:

a) Organização e estudos das informaçōes contidas em arquivos e instituiçōes.

b) Coleta de campo

b1) Levantamento das formas de uso do solo.

b2) Entrevistas com a população local.

b3) Cobertura fotogräfica dos equipamentos significati vos do bairro.

c) Pesquisa junto às mídias.

d) Palestras e conferências.

A) Instituições e arquivos

1. SINDUSCON-SP (Sindicato da Ind. da Cons trução Civil de Grandes Estruturas). Junto a esta instituição conseguimos, através da aplicação de um questionārio, in formações sobre o tipo de interesses e tendências da construção civil para o Bela Vista. Ao mesmo tempo realizamos u ma entrevista com um dos seus superintendentes.

2. EMBRAESP (Empresa Brasileira de Estudos de Patrimônio). A mesma forneceu-nos um relatório de todas as construções feitas no Bela Vista entre 1985 e 1987 , permitindo-nos registrar o padrāo de construçāo para o bairro e suas tendências nestes anos.

3. SODEPRO (Sociedade de Defesas das Tradiçōes e Progresso do Bela Vista). Fizemos uma entrevista com seu presidente para a verificação da forma de atuaçāo da 


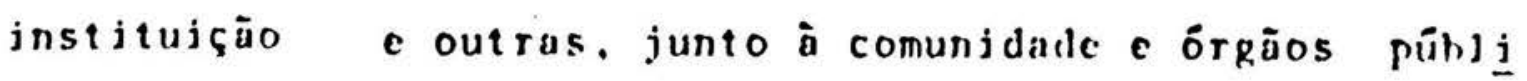
cos, tanto sobre o que está sendo fejto para a prescriasão do bairro, como também, para obter informaçōes históricas sobre o mesmo.

4. SEMPLA-PMSP (Secretaria Municiapl de Planejamento de Sāo Paulo). A mesma nos ofereceu valiosa contribuição sobre dados estatisticos a respeito do bairro, dados demográficos, renda, formas de uso para o período de 1980 a 1986. Nos arquivos desta Secretaria conseguimos cote jar um conjunto de leis e decretos sobre a ocupação do solo uso e parcelamento, ao mesmo tempo, localizar obras sobre todo o processo de tombamentos no bairro.

5. CONDEPHAAT. Junto ao mesmo foi aplicado um questionário para avaliarmos a importância do bairro no conjunto patrimonial de São Paulo e expectativa deste Conse tho em relaçāo ao mesmo.

6. SEHB-SP (Secretaria da Habitação e Desenvolvimento Urbano - SP). Em entrevista neste órgão consegui mos localizar um documento sobre a abertura de concurso público em âmbito nacional para a Renovação Urbana e Preserva ção do bairro do Bexiga.

7. DPH - PMSP (Departamento de Patrimônio Histórico da Prefeitura Municipal de São Paulo). Além da lo calizaçāo daquela obra inédita sobre o bairro da Bela Vista, conseguimos consultar a mapoteca, onde nos foi possivel identificar antigos mapas de São Paulo e posição do bairro no conjunto urbano. 
B) Coletas de bados

1. Além dos dados obtidos pela Base de Dados - PMSP sobre as formas de uso do solo no bela vistapro curamos elaborar nossa própria coleta, pois aqueles se refe rem a dados gerais sobre o bairro, quanto para nós se fazia necessário perceber as diferenciaçōes internas ao mesmo.Ape sar daqueles terem sido valiosos quando queriamos generalizaçōes sobre o Bela Vista como um todo, eles não se prestavam àquelas diferenciaçōes internas. Mesmo sendo dados trabalhados com critérios de levantamentos diferentes, eles permitiram grandes contribuiçōes. A Base de Dados trabalhou com os tipos de ocupaçōes em metros quadrados; nōs somente com a ocorrência dos fatos. Apesar das diferenças nos crité rios, percebemos que as relaçōes entre as grandezas se mantiveram próximas. Ex.

$\begin{array}{lcc}\text { Uso } & \text { Nossa Pesquisa } & \begin{array}{c}\text { Base de Dados- } \\ \text { PMSP }\end{array} \\ \text { Residencial } & 59,308 & 55,428 \\ \text { Comércio/serviço } & 37,088 & 44,048 \\ \text { Indústria } & 3,598 & 0,498\end{array}$

Este fato permitiu-nos grande margem de segu rança no trabalho com os dados.

De um universo total de 2.775 lotes da área de pesquisa, nós investigamos 1.584, correspondendo, portañ to, a 678 daquele universo. A escolha das ruas para o levan tamento foi feita de tal modo que toda a área da pesquisa ficasse bem contemplada pela coleta, mantendo-se um equilibrio entre as diferentes äreas do bairro. A base territorial para o registro das informaçōes foi o lote, registrandose para cada lote os värios usos encontrados para nossos ob 
jetivos, tendo sido importante, registrar, tanto a frequêrcia do fenómeno quanto a espacialidade. Quando o mesmo 10te apresentava mais de uma ocorrência, todas cram, pois, registradas. Não trabalhamos com o conceito de uso misto. pois este camuflaria os nossos objetivos. As ruas pesquisa das neste levantamento de uso do solo estāo apresentadas em carta que acompanha este trabalho (Fig. 1). Para facili tar a coleta e seu respectivo registro na planta do bairro foi estabelecida uma codificação numérica para as formas de uso. Os dados coletados foram analisados em sua frequên cia visando perceber a concentração ou não do uso. Assim, conseguimos constatar que o bairro apresentava internamente tendências espaciais diferenciadas. A partir daí, dividimos o bairro em āreas compartimentadas. Compartimentação esta sobre a qual esta fundamentada grande parte da pesqui sa. Nāo podemos dizer que este levantamento tenha revelado algo diferente que a nossa praxis jā nāo tivesse revelado; - que nos permitiu foi a comprovação cientifica, metódica, dando-nos segurança nas conclusões, permitindo, assim, no dizer de Humberto Eco "que outros continuem a tese para contestā-la ou confirmā-la".

\section{Entrevistas.}

Não foram muitas as entrevistas por nós rẹ lizadas. No total foram umas dez, na medida que jā havía mos localizado muitas e criteriosamente elaboradas pelo DPH-PMSP e contidas em seus arquivos. Para as nossas entre vistas procuramos selecionar algumas pessoas indicadas no próprio interior do bairro e que lä residissem há muito tem po. Cada discurso, depois de gravado, foi transcrito procu rando-se manter a fidelidade da forma apresentada. Estas 


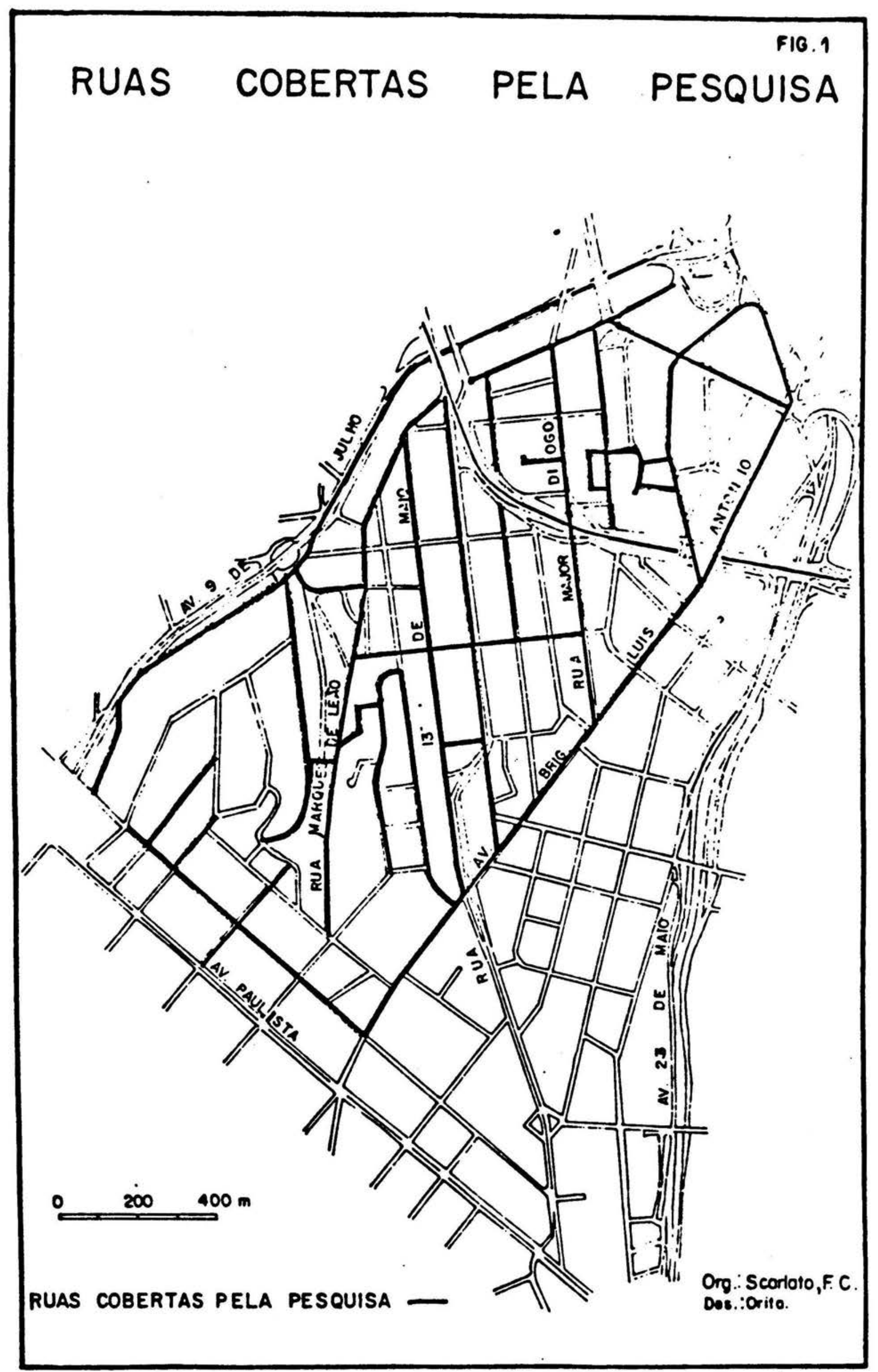


fontes foram muito importantes para trabalharmos com o unjverso da ideologia c do imaginário, temas fundamentais para nossa presente pesquisa.

\section{Cobertura Fotográfica}

Com a mesma procuramos deixar registrados os componentes básicos da morfologia urbana, como também, obter imagens dos pontos mais altos que possibilitassem uma visão completa do bairro - volume e forma do espaço edifica do, permitindo-nos documentar e analisar a distribuiçāo espacial do processo de adensamento, verticalização e alteraçōes provocadas pelas grandes vias que passaram a cortar o bairro. Entre as 190 fotos tiradas, selecionamos algumas pa ra integrar a tese. Estas fotos permitiram que percebesse mos fenômenos identificados cartograficamente.

4. Elaboraçāo cartográfica 
2. INTRODUÇA()

Ao caminharmos pelas ruas do Bexiga para rea lizar este trabalho de pesquisa tivemos que exorcizar todos os demônios da saudade e das paixões que nos ligam ao bairro. Não foi tarefa fácil. Em cada esquina e em cada casa uma lembrança. Lembrança da infância, da adolescência, viví das entre aqueles casarōes e ruas estreitas. 0 rigor de método, a clareza nos objetivos a serem alcançados e o compro misso com a verdade representam o melhor caminho para exorcizar o "pecado da paixão". Se, de um lado, a existência ví vida no bairro pode ser a garantia de um universo de informaçōes históricas, capaz de servir de guia para a colocação e elucidação de problemas desta realidade, também, pode de outro lado, implicar na necessidade de um esforço maior para ver de forma transparente esta mesma realidade:

"Eis porque cremos ser licito dizer que mesmo o mais experimentado e melhor dotado dos pesquisadores científicos não deve confiar unicamente na sua exćlusiva experiência, mes mo quando esta the haja permitido obter expressivos triunfos na descoberta de propriedade dos corpos e de leis da natureza, para, apoiado apenas sobre esta base necessāria, mas por si só insuficiente, permitir-se emitir opiniōes gerais, interpretativas doutrinārias, ignorando ou menosprezando 0 imenso esforço de esclarecimento racional que a filosofia vem secularmente produzindo. Precisa aproveitar o inapreciável capital representa do pela vivência direta da ação investigado- 
ra, fim de submetê-lo ao influxo lluminador do pensamento teórico que, unindo-se ao exercício da pesquisa, numa síntese lógica superior, chegará então a compor a correta doutrina da pesquisa cientifica". (Vieira Pinto, p. 5)

A História, compreendida dialeticamente, permite-nos ver a realidade de forma transparente sem que sejamos excluidos dela. Coloca-nos como agente ativo e pas sivo no processo. Ao invés de negar a nossa experiência, o valor da nossa ação, valoriza-a. Ela passa a ser mais do que uma teoria para ser a própria consciência da realida de. Quanto mais transparente for, maior será a garantia de alcançarmos aquela sintese lógica superior:

"A atividade teórica em seu conjunto - como ideologia e ciência - considerada também ao longo de seu desenvolvimento histórico, só existe por e em relaçāo com a prātica, já que nela encontra seu fundamento, suas fina lidades e seu critério de verdade..." (Sánches Vásquez, p. 203)

Assim, a pesquisa de campo, mais do que dados empíricos coletados, permite-nos, neste caso, uma mudança gradativa no nível de percepção e consciência do bairro. Permite ver as mudanças fisionômicas e culturais . Sei que este não é mais o "Velho Bexiga". Porém, cabe-nos provar o fato, atravēs da investigaçāo histórica, à qual nos propomos a partir de agora. Não vamos nos colocar no passado, mas trazê-10 como referência para perce bermos o que mudou e o que nāo mudou no tempo e no espaço. Assim, a realidade torna-se viva e dinâmica. A História torna-se processo dentro do qual poderemos nos situar, des tilando nossas ideologias abrindo-nos para a praxis: 
“...A praxis se nos apresenta como uma ativi dade material, transformadora c ajustada a objetivos. Fora dela, fíca a atividade teór ca que não se materializa, na medida em que é atividade espiritual pura. Mas, por outro lado, não hã praxis como atividade puramente material, isto é, sem a produção de finalida des e conhecimentos que caracteriza a atividade teórica. Isso significa que o problema de determinar o que é a praxis requer delimi tar mais profundamente as relaçōes entre teo ria e prática..." (Sánches Vazquez, p. 208)

Nosso propósito não é digressionar na História como mera atividade espiritual ou coletando material in formativo, mas empenharmo-nos num trabalho cujo objetivo é estar presente e participando nas transformaçōes do Bexiga.

O Bexiga real é o Bexiga histōrico, uma totą lidade concreta, transparente, onde podemos perceber suas contradiçōes fundamentais, sem aquelas mistificaçōes encontradas nos discursos dos "boêmios", jornalistas, escritores, pessoas interessadas em criar um mundo de fantasias para usufruirem benefícios econômicos ou então, em criar uma realidade espaço-temporal capaz de preservar-1hes a condiçāo existencial. Portanto, em oposição ao Bexiga real temos o imaginārio. Um mundo onde se finge que as coisas não muda ram; onde a ameaça do novo, que devora as tradiçōes e com elas a lógica de uma existência ten que ser destruída. Desta forma criam-se alegorias, roupas velhas penduradas ao lon go das ruas do bairro tentando criar uma atmosfera de italianidade: proposta para construção de grandes arcos, semethantes aos existentes nas cidades italianas, na tenta tiva de se manter vivo algo que nāo mais existe, tornandose mais um "ritual de mumificação" do que a garantia da per 
manência viva daquelas tradiçōes:

"Um novo espaço é construido, um velho espa ço assume uma nova dimensão de significado. Para que isto ocorra é necessário uma dimen são coletiva. Uma dimensão coletiva ligada a uma exigência de fundamentação, refunda mentação de valores". (Bettanini. p. 96)

0 que se pretende dentro deste mundo imaginário é esta fundamentação de valores. Porém, o que não percebem é que todas estas representações alegōricas não encontram mais legitimação na realidade coletiva do bairro, que é necessário se buscar novos fundamentos para explicar - atual bairro, cuja essência nāo é mais a mesma. Sobre a natureza deste processo de renovaçāo histórica, assim, se coloca Agnes Heller:

\footnotetext{
"...São elas os grandes túmulos da história mas igualmente seus berços. Em determinado ponto, estruturas que foram essenciais submergem nas profundidades, para ai continuarem uma vida inessencial do ponto de vista social global; e outras se elevam, passando da inessencialidade à significatividade..." (Heller, p. 3)
}

A essência do real no Bexiga deve ser busca da na maneira como esta sociedade está aí organizada. No nivel das suas condições concretas de existência, na divisāo social do trabalho, nas formas de uso do espaço, no desenho das ruas e casas:

"Maurice Halbwachs mostrou, do mesmo modo. - papel desempenhado pelo espaço na memória coletiva, papel esse que se explica pela 'a derência do grupo ao seu lugar' no espaço. pelo fato de ter o lugar 'recebido a marca do grupo' e de haver, assim, um 'espaço jurídico', um 'espaço econômico', um 'espaço religioso'..." (Cuvillier, p. 142) 
pede a mesma de propor soluçöes objetivas para sous probemas. Não șerá com roupas penduradas ao longo das vias públicas ou com projetos visando ressuscitar um italianismo a gonizante que se resolverāo os problemas básicos do Bexiga Salvar sua memória não significa fantasiar o bairro, criar uma atmosfera de "irrealidade". Isto nos leva a invocar o seguinte pensamento de Umberto Eco: "Mas ê' claro que esse corpo-a-corpo com a história, ainda que patético é injustí ficāvel, porque a histōria não se imita, se faz..." (Eco, p. 37). Nós, no processo da produção do conhecimento e consequentemente da realidade, não podemos escolher pela existência ou não da instância do imaginário na mesma, mas cabe-nos a possibilidade da crítica da história para criar a sua transparência.

Entre muitas citaçōes feitas pela imprensa sobre a realidade do Bexiga, repletas de romantismo e subjetividade, destacamos as seguintes: "...0 bairro da Bela Vista, carinhosamente chamado de Bexiga, vem resistindo ao tempo...", jornal 0 Estado de São Paulo - 14/7/87; "0 Bexí ga não precisa de muito dinheiro, nem deste negócio de zoneamento, que ninguém entende o que é. 0 necessārio é somente, que alguém inteligente resolva consertar um pouco as ruas, incentivar os proprietários a recuperarem seus imóveis, construir alguns estacionamentos...", declaração feita por um importante líder da comunidade do bairro ao jornal Shopping-News-City News - 30/8/87; "Que será do Bexiga? 0 bairro da Bela Vista está condenado, caso o projeto seja aprovado. "Como o Bela Vista, o nosso Bexiga, fica entre o Centro a Paulista, a Comissāo de Zoneamento entendeu que ele deve ter o mesmo adensamento da ärea central. E um raciocínio simplista. Não dá para aceitar uma 
argumentaçāo dessas. O pijxiga e um hairro tradicjonas da c dade, que ficará iguas ao centro. Toda sua tradição irá acabar, scrá expulsa pela valorização imobiliária" - jornal o Estado de São Paulo - 31/8/87; "Mas das velhas tradiçōes do Bexiga, isto $\bar{e}$, pois ainda restam, mais fortes que as $1 \mathrm{em}-$ branças, as memórias visuais: ruas estreitas e tortuosas. calçadas de paralelepipedos, postes enferrujados e velhos lampiōes a gás... balcōes e portões de ferro, janelas altas com bandeiras coloridas, persistem ainda, na memória audití va e olfativa, a recordação do ruído e dos cheiros inesquecíveis das macarronadas". "Memórias Visuais do Bexiga", jornal da Bela Vista, maio de 1978.

A sequência deste material publicado pela imprensa jornalística revela o tom apaixonado dos discursos quando falam do Bexiga. Em muitos momentos tem-se a impressão que as coisas do bairro pouco ou nada mudaram, que a preservaçāo daquilo que ainda sobrevive poderā ser facilmen te conseguida dependendo da força de vontade de algumas ins tituiçōes, instituiçōes estas que tambēm podem ser questionadas em sua existência. Sāo discursos ideológicos que deverão passar pelo crivo da nossa crítica histórica e geográfica para conseguirmos aquela transparência jā referida.

Nāo é somente a imprensa jornalística que trabalha com um nível ideológico de discurso. Um número relativamente grande de trabalhos de pesquisas, publicadas ou nāo sobre o bairro, utilizam este tipo de discurso. Podemos afirmar que tivemos acesso às principais obras escritas sobre o Bexiga. Poucas foram aquelas que se aproximaram da realidade objetiva do bairro. As criticas a estas obras serão feitas ao longo do trabalho e mais detjdamente na unida 
de - Sohrevivência c Mistificaçōes nas Tradiçōes: Uma ideo logia do "bixiga". F. cesta reabidade objetiva que procurare mos cercar.

0 tema da pesquisa 0 Real e 0 Imaginário no Bexiga: Autofagia e Renovação Urbana no Bairro , surgiu como uma preocupação nossa com os desencontros entre o estado e a sociedade no Brasil.

Conhecendo de perto a realidade do bairro. sua situação histórica dentro de São Paulo e o que vem sen do escrito sobre o mesmo, verificamos que existe um desencontro entre a realidade objetiva e os discursos ideológicos sobre o mesmo, tanto por parte dos poderes públicos co mo dos membros da comunidade. Esta realidade está,ca da vez mais, se tornando menos transparente. Os primeiros, criando projetos e mecanismos de intervenção no bairro de forma demagógica, revelando subliminarmente comprometimentos com segmentos da classe dominainte, interessados no potencial imobiliärio do mesmo; os segundos, lutando pela sobrevivência de suas tradiçōes e interesses ameaçados pelas transformações urbanas, revelando nesta luta que representam uma minoria fragilmente organizada para enfrentar o jogo do sistema. Aqueles representando a racionalidade e o poder: estes, o romântico, arrematando os destroços do nau frágio, entre destroços, além das tradiçōes, outros tipos de interesses individuais de natureza econômica, pouco transparentes no discurso em defesa daquelas tradiçōes. Aș sim, o bairro do Bexiga faz emergir as contradições entre - estado e a sociedade, o individual e o coletivo, o velho e 0 novo. 
" capitalismo "central" ou "petiférico" seja como uma realidade histórica concreta ou.como doutrina. revela-sí, em última instância, incapaz de propor solução para os grandes problemas sociais à medida em que perpetua a dominação de classe, matriz de todas as injustiças sociais. O urbanismo, como tentativa de ajustamento entre a sociedade e a cidade, criando formas saudáveis de convivência social, encontra sérios obstáculos no capitalismo. As melhorias con seguidas na qualidade de vida urbana, significam a exclusāo de uma parcela significativa dos benefícios criados.

Vivemos a realidade de uma sociedade capitalista. Dependente ou não, produz e réproduz tipos de relaçōes discriminatórias e segregadoras, variando de uma situa ção para outra na escala de grandeza e nāo de natureza nestas relaçōes. Isto nos leva a pensar o urbanismo capitalista como um instrumento nāo de superação das injustiças e conflitos urbanos, mas como uma forma de acomodação dos mes mos.

A realidade urbana do bairro do Bexiga é um desafio ao planejamento: preservar uma memória que se desfaz com os velhos casarōes ocupados por uma populaçāo que ontem foi o italiano e o oriundi, tão caros para as tradiçōes do bairro, vivendo lado a lado com os negros, definindo uma relaçāo por muitos considerada integradora, mas que, na verdade, guardava uma profunda marca de racismo. Hoje, al habitam simplesmente brasileiros, na maior parte homens pobres. tragados pela autofagia urbana de São Paulo. Os primeiros, outrora maioria, hoje se encontram reduzidos a quase minoria. Os imigrantes vindos de outras regiōes do Brasil e que se dirigiram para o bairro do Bexiga contribuiram 
para a perda de jelentidade cultural do mesmo. Hoje o "italianismo" do bairro é questionado: sobrevivendo em alguns setores comerciais como os restaurantes, padarias e festas religiosas como a de Nossa Senhora da Achiropita e São José. Os segundos, simplesmente chamados de nordestinos pelos primeiros, de forma discriminatória, ocupam a maior parte dos cortiços cujo número cresceu muito nos últimos anos.

O Bexiga estā em transe. Este fato aparece de forma pouco transparente nos estudos e projetos de reno vação feitos para o bairro. Intencionalmente ou não, parece-nos que estes projetos e estudos ignoram as profundas mutaçōes oçorridas no Bexiga. As transformaçōes irreversíveis pelas quais passou o bairro apresentam-se em descompasso com as propostas contidas nos projetos para a solu ção de seus problemas. Tocam na ponta do iceberg, subestimando problemas como: As condiçōes de deterioração das edificações, a força do poder econômico sobre os imóveis "prọ tegidos" pela Lei 28-200, a presença numericamente expressiva de uma populaçāo encortiçada, "desprotegida" pela lei e a mercê de açōes do poder público, a exemplo da ação da Prefeitura de São Paulo sobre os cortiços das ruas Jandaia e Assembléia, colocando na rua centenas de pessoas para no lugar realizar obras de paisagismo urbano. O Bexiga vive - transe de um sistema incapaz de suportar suas contradi ções bāsicas, onde os interesses do grande capital ditam as regras do sistema e onde as leis do capital definem a natureza da urbanizaçāo fazendo da cidade seu centro nervo so. Os problemas do Bexiga representam o microcosmo de um processo de urbanização que é universal ao capitalismo. Problemas semelhantes sāo vividos em outros bairros e cida 
des do sistema. A anarquia capitalista e "camisa de força do planejamento". fazendo com que o capitajismo viva cm constante transe, inviabilizando qualquer prática democrática de urbanismo. 0 "individualismo" como essência daquela anarquia, estará sempre favorecendo as classes dominantes na apropriação do espaço.

Dentro desta primeira visāo generalizadora da urbanizaçāo e do urbanismo como forma de intervenção e planejamento urbano, cabe-nos as perguntas: - Se a produ ção e reprodução do espaço urbano seguem as leis gerais da acumulação do capital, onde residirão as diferenças especí ficas de uma cidade em relação a outra? Devemos admitir que aquelas leis gerais que regem a evolução e transformação do sistema, portanto, sua essência, criem um mundo material onde as formas se diferenciem em função de uma cria tividade nascida das representaçōes ideológicas produzidas no ṕrocesso histórico? Valeria dizer que a produção econômica material representam instâncias que se desdobram em outras que chamaríamos de culturais e ideológicas. As primeiras representariam a essência e as segundas o contingen te da realidade.

Sabemos que a ideologia é a instância das representaçōes formais da realidade concreta, nascida das relaçōes concretas entre os homens. Quase sempre se abandonain no estudo das ideologias as bases geogrāficas nas quais foram produzidas. Como dissemos anteriormente, as ideolo gias são contingentes no processo histórico. Sua natureza está numa relaçāo direta com aquelas relaçōes que possuem uma espacialidade. Nos estudos de como nascem as ideologias, geralmente se invertem os papéis. 0 espaço geogräfico. 
que representa cm újtima instâncja uma natureza histórica, enquanto instância cconómica c material do real, aparece na maioria daqueles estudos como algo contingente a ideo logia como a essência do real.

Esquecem-se que as ideologias religiosas, po líticas, econômicas, estéticas, e outras mais, aparecem na hiştooria em certas condiçōes geográficas. Assim, sendo, o ponto de partida para a compreensão das mesmas é admitir que aquelas relaçōes concretas entre os homens das quais elas nascem são também definidas no e com o espaço geográfico. Cabe, portanto, na relação espaço geogrāfico e produ ção ideológica definirmos o que é essencial e contingente.

A dialētica não deve ser entendida como uma pasteurização da realidade, usada como instrumento de ataque contra esta preocupaçāo de diferenciaçāo do que é essencial e contin gente, tachando de "formalismo" tais preocupaçōes. Sem diferenciarmos estas categorias não poderemos entender os saltos qualitativos na mudança histórica e tão pouco tentar mos compreender a geografia e as ideologias. Devemos pensar o espaço geográfico não mais como o "palco" onde se produzem as mesmas, mas como uma instância determinante.

Para podermos assumir uma praxis geogräfica será necessārio superarmos todas estas questōes ou contentarmo-nos com a posiçāo de "fotōgrafos" da paisagem. Esta praxis passa pela compreensão de que o objetivo da Geografia - o espaço geogrāfico é um espaço produzido e "inten cional" e não simples suporte social. Somente quando conse guirmos dar vida ao objeto da nossa ciência, quando compre endermos que seu objeto tem uma História e percebermos a dimensão intencional do mesmo e que determina formas de re presentaçōes e ideologias que as pessoaś se "enclausuram"em 
representaçöes de espacos, é que poderemos como geógrafos propor cegir nas transformaçōes da realidade.

Neste universo de preocupações foi que surgiu o tema sobre o espaço geográfico do Bexiga, a busca de sua identidade geográfica. Quando conseguirmos perceber es ta "identidade" com todas suas contradiçōes, poderemos ter uma posição crítica sobre o futuro contido nos projetos elaborados para o bairro.

Assim dito, podemos partir mais objetivamen te para a formalização da tese da pesquisa. o bairro do Bexiga é reconhecido como um centro de tradições histōri cas relacionadas com a imigração italiana dentro da sociedade de São Paulo. Porém, estas tradiçōes e seu patrimônio arquitetônico e urbanístico encontram-se descaracterizados, definindo um novo perfil e uma nova identidade do bairro . A luta para sua preservação está condenada ao fracasso devido aos seguintes fatores: "Estágio avançado de deteriora ção da quase totalidade das antigas habitaçōes; Legislaçāo pública ineficiente na preservaçāo do conjunto dos bens culturais e arquitetônicos e incapaz de conter o poder eco nômico da urbanizaçāo capitalista brasileira; A fragilidade organizacional e pouca representatividade das entidades comunitārias que lutam para a preservaçāo das tradiçōes do bairro; A pouca transparência para os setores püblicos e da comunidade daquilo que sobreviveu do processo de metropolização que atingiu o bairro e efetivamente deva ser pré servado como memória histórica. Para finalizar devemos res saltar que a nova identidade e novo perfil do bairro, ou seja: as novas formas de uso e ocupação do solo no Bexiga, estāo cada vez mais distantes daquelas tradiçōes, que so- 
hrevivem ainda nas ideologias de escritores, pequenos nego cjantes que se beneficiam com a prescrvação das tradições c no coração de alguns saudosistas que ainda não percebe ram que estão "fora do lugar". "enclausurados" na ideologia do Bixiga.

A medida que a tese for comprovada, podere mos ver o Bexiga como, uma realidade transparente, permitin do uma praxis verdadeiramente transformadora não só do bairro, mas também, de outros níveis da realidade social. 
II PARTE 
3. EVOLUÇスO I: AUTOIACIA DO BAIRRO

"A sensibilidade, o pensamento, a consciência são os produtos mais elevados da matéria organizada de uma certa maneira..." (Lenine, p. 45).

Apesar de muitas mudanças sofridas na paisagem e formas de uso do solo urbano, o Bexiga ainda guarda lembranças deixadas do início do século $\mathrm{XX}$ : o traçado de suas ruas, a grande parte de suas edificaçōes, que apesar das alterações sofridas nas fachadas, foram mantidas em suas estruturas, ou seja: nas relaçōes existentes entre o lote a planta. As funçōes econômicas que atualmente estão ocupando o bairro - atividades de serviços ligados ao lazer - contribuiram para a descaracterização de uma grande parte das fachadas originais destas edificaçōes. Os propritários, ao alugarem os imóveis para estas novas atividades, raramente demonstravam nesta transação alguma preocupação com a preservaçāo das características originais destas edificaçōes, sendo comum entre eles considerarem as alteraçōes das fachadas, adaptadas às novas funçōes, como "benfeitorias", valorizando os imóveis para a exploraçāo econômica . Sobre os imóveis "reformados", na passagem das chaves, pode riam cobrar melhores aluguéis. A partir da década de setenta, quando o bairro foi invadido por bares de encontro, casas de diversōes noturnas, etc, a descaracterizaçāo foi for temente acentuada e nāo se presenciou qualquer forma de par ticipaçāo do poder público na preservaçāo paisagística do 
bajrro. Os proprictários, cmbalados por "gordos" alugués . cntregaram os imóveis aos cmpresärios para as meraçōes das antigas fachadas, em muitos casos, inclusive, para alteraçōes das plantas originais. Cabe-nos lembrar aqui, a anālise feita por Cervellati e Scannavini:

"O paralelismo e a estreita interdependen -
cia entre o desenvolvimento das forças pro-
dutivas e o desenvolvimento urbano, dão lu-
gar a uma cidade que vai perdendo cada vez
mais os caracteres de organização coletiva,
para converter-se em algo cada vez mais re-
lacionado com o modelo de produção capita-
lista." (Cervellati e Scannavini, p. 125)

Sabemos que o grande capital financeiro imo biliário desempenha um papel importante nas transformaçōes do espaço urbano de qualquer cidade capitalista, porém,não devemos substimar a açāo da pequena burguesia e mesmo, do proletariado enquanto "classe em si" desprovida de uma consciência histórica de classe, neste processo desenfreado de transformaçōes urbanas. A deterioração dos velhos casarōes, 'ho- je transformados em cortiços, revela a natureza especulatí va da ação daqueles proprietārios que, enquanto aguardam a valorização do terreno, vivem da renda de aluguéis, criando uma cadeia de sublocações. Desta forma a deterioração física das edificaçōes torna-se quase inevitável. Por outro lado, pequenos proprietários e assalariados, vendo a perspectiva de obterem através de aluguéis uma renda complemen tar ao salärio, passam a alugar os pavimentos inferiores de frente para a rua para atividades de serviços e mesmo industriais, como pequenas oficinas de marcenaria, conser tos em geral e para aquelas atividades ligadas à vida noturna do bairro. Qualquer açāo planejadora sobre o espaço 
urbano capitalista terá que enfrentar sempre ação da pequena burguesia e de um proletariado que para poder sobreví verem ou melhorarem sua condição de existência terão que entrar no jogo da especulaçāo imobiliária capitalista. No Bexiga, povoado desde períodos antigos por uma população de pequenos artesãos e trabalhadores autônomos, estas relaçōes acabam sendo reforçadas, principalmente entre seus mais antigos moradores, hoje os grandes defensores das tradiçōes do bairro. Conciliar as exigências de lei de zoneamento, no caso, aquelas estabelecidas pela 28-200, com os interesses econômicos da população, torna-se difícil.

O Bexiga, ainda hoje, é ocupado em grande parte por edificaçōes baixas, sobrados. e casas terreas. Suas ruas e quarteirōes, seu traçado viārio nos dias de hoje, seguem bem de perto a planta original do bairro, aquela do século XIX, quando se iniciou o loteamento do mesmo. As grandes obras de engenharia alteraram as relaçōes de circulação de muitas ruas, chegando mesmo, a obstruir . algumas delas. Porém, as consequências para o bairro foram mais pela intensificação dos fluxos do que pela mudança das rotas que caracterizavam os antigos eixos implantados pelo projeto original. Deve-se acrescentar o grande elevado que foi construido sobre a rua Santo Antonio com a implantaçāo do "Anel de Estacionamento do Centro 1".

Para una melhor compreensāo da atual geogra- fia do Bexiga, faz-se necessārio analisar sua inserção no processo de expansāo urbana da cidade de São Paulo a partìr do século XVIII, quando históricamente tivemos as primeiras referências sobre o bairro indicando sua localizaçāo e rela çōes dentro da cidade. 
I.m Saint llijajre (liagens à Provincla de São Paulo), localizamos os anos de 1789-1792 como o registro mais antigo do nome Bexiga, referindo-se à área ocupada hoje pelo bairro. liesta época tanto a economia de são paulo como sua urbanização situavam-se dentro de marcos pouco expressivos, comparativamente aos centros dinámicos da economia colonial brasileira. Diferentemente daqueles centros, voltados para uma economia de natureza exportadora, a cidade de São Paulo, com menor dinamismo, vivia mais em função de uma economia articulada internamente do que, como as demais, em função dos grandes mercados de exportação agríco 1a. Para Caio Prado Junior, a questão se coloca da seguinte forma:

"A descoberta do ouro em Minas Gerais, pouco depois seguida pela de Goiás e Mato Grosso. representa a meta final do esforço tenaz dos paulistas durante quase dois séculos, voltado ao reconhecimento de todo o território que havia de constituir o Brasil de hoje, e à procura de metais preciosos. Realizado este fim, São Paulo encerra sua obra e entra numa fase de prolongada estagnação. Não só interrompe sua expansão colonizadora, despovoa-se... O século XVIII é um período em que toda a atividade da colônia está canalizada para as minas; a agricultura decai enormemen te, mesmo no Norte, onde florescer com tanta pujança no século anterior. Esta fase de atividade extrativa quẹ nāo dava margens para outras ocupaçōes, ou dava-a em proporções muito pequenas, só se interrompe com o esgotamento, aliás prematuro, das mina. Isto mais ou menos pelos fins do século XVIII...0 início do século XIX, marca por conseguinte - abrir de um período de reorganizaçāo econômica. A colonizaçāo do território paulista, sua ocupação e exploração, estacionaria e 
mesmo em regresso durante ó periodo preceden te, sc intensifica não so nas zonas já penctradas, mas nas demais que restavam por desbravar..." (Caio Prado Jr., p. 32)

Desta forma vimos que a força econômica de São Paulo dentro da sociedade agrário exportadora brasileira inicia-se verdadeiramente a partir do século XIX, o que não nega o fato de São Paulo durante a fase da mineração, ter definido sua hinterland, enquanto um "espaço marginal" na época. Somente a partir do século XIX é que a economia paulifta, com o café, se projeta como centro dinâmico da economia brasileira.

0 crescimento do bairro dentro da cidade de São Paulo esteve circunscrito a esta mudança no ritmo do crescimento econômico da cidade. Nas referências feitas por Saint Hilaire na obra citada, o bairro do Bexiga aparece co mo um espaço externo ao centro urbano de São Paulo; uma por ta de entrada e de saída para os caminhos em direção ao interior e litoral da província. Enquanto a cidade viveu o sé culo XVIII, poucas foram as mudanças verificadas nas funçōes e no espaço físico do "Piques".

A partir do início do século XIX, quando começaram a se verificar mudanças significativas na economia brasileira, retomando-se o processo de crescimento da econo mia agrärio-exportadora, dinamizando-se novamente a produ çāo agrícola no Brasil, Sāo.Paulo passou a despontar como uma das regiōes mais promissoras para a nova fase, seja através da produçāo canavieira ou do café, tornando-se este último a grande riqueza nacional, colocando São Paulo, a partir de então, na vanguarda do processo de crescimento na cional. 
Até os fins do século XVIIJ, a cldade de São Paulo representava um espaço urbano de pequena signjficação: "A situação pouco se modificou até os últi mos anos do século XVIII. Mas sobretudo no começo do setecentismo - em torno de 1720 era por isso ainda bastante reduzida a área da cidade. 0 seu núcleo urbanizado se concen trava todo no triângulo, cujos vértices lembrou Alcantara Machado - ficavam as igrejas de São Francisco, 'de São Bento e do Carmo. $\lambda$ esquerda do Anhangabaú e à direita do Tamanduatei. na "banda do além" eram os campos de criaçāo; os currais de gado, as " matas do Caaguaçu e do Ipiranga, as chācaras e as casas de campo..." (Marzola, p. 20).

As terras nas quais se situava o Bexiga, ficavam na "banda do além". O Bexiga nasceu de uma daquelas chácaras localizadas ao redor do centro da cidade. Com o crescimento econômico da província, verificado a partir da segunda metade do século XIX, a mancha urbana, o espaço edi ficado da cidade foi se estendendo. A planta levantada em 1810 pelo capitão dè engenheiros Rufino J. Felizardo e Cos t'a (Fig. 2) permite-nos identificar aquele que foi 0 marco inicial do bairro - o Piques - ponto de partida para ocupaçōes posteriores das "colinas do Bexiga" (Para os antigos moradores do atual Bela Vista, Piques é sinônimo do Bexiga, também chamado de "Baixo Piques").

O lugar representou um ponto importante para a cidade. São Paulo na época encontrava grande dificuldade para o abastecimento de água para a população. 0 Piques, on de hoje se localiza o 19 rgo da Memória com sua pirâmide,fun cionava como um ponto de abastecimento de água coletada do "Tanque do Reuno" localizado ao longo do vale do Saracura no lugar onde hoje se encontra aproximadanente a rua Major Quedi 


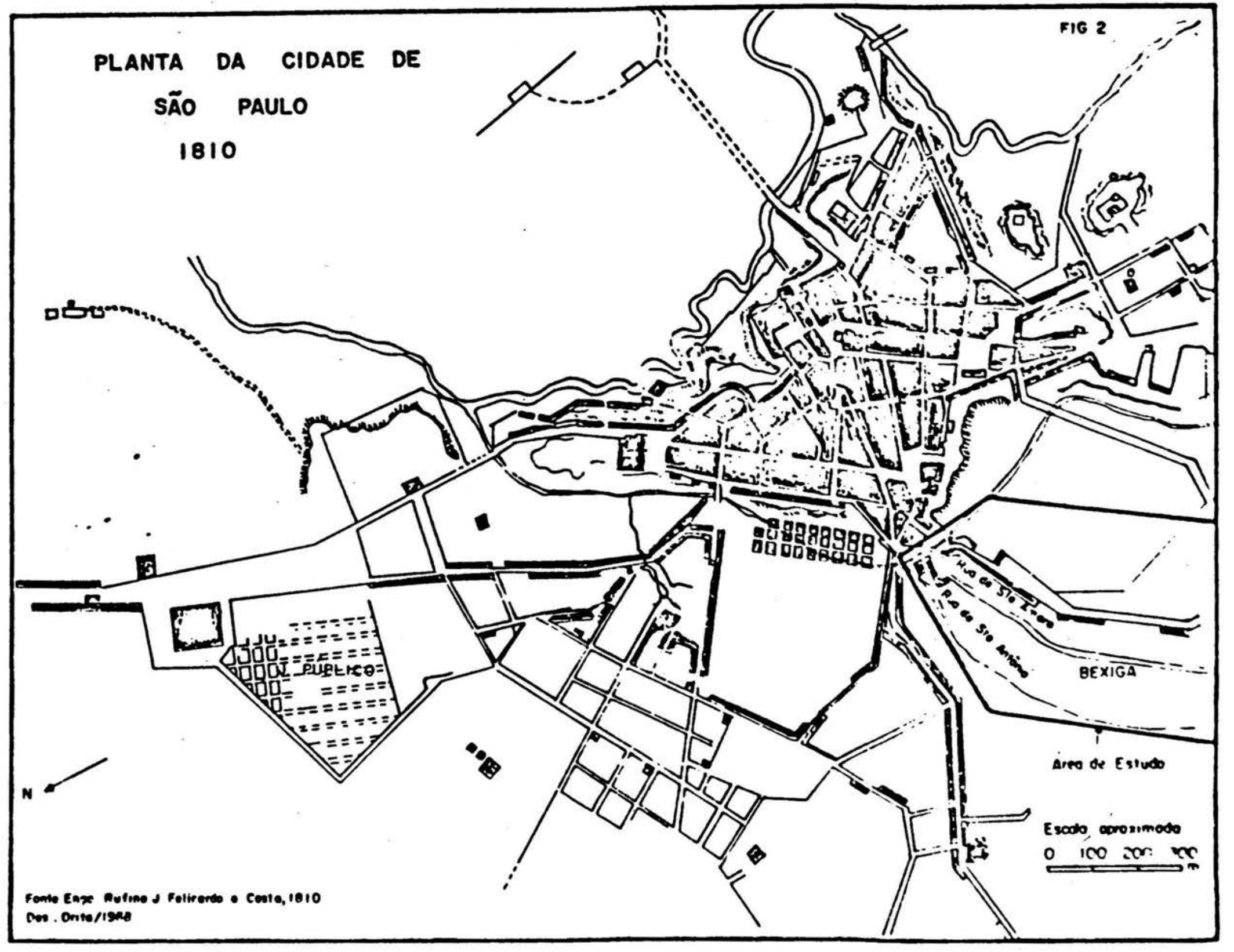


Nho: talvez o "Baixo l'jques" tenha surgido para djferenciar a par te majs bajxa do vale, onde hoje está localizada a praça das bandeiras, daquela parte mais elevada junto ao obelisco do largo da Memória na rua Quirino de Andrade. A praça das Bandeiras, ou "Baixo Piques", também era chamada de "Largo do Bexiga".

A referida planta não nos revela a presença de qualquer processo de urbanização entre o montante do ria cho Anhangabaú - Alto Caaguaçu - correspondendo hoje ao espigão onde está localizada a av. Paulista e vale do Saracura, hoje av. Nove de Julho. Esta área compreendida entre os dois riachos corresponde ao atual bairro da Bela Vista, antigamente "Chācara do Bexiga" (Fig. 3). Esta chācara esta va localizada nos "campos do Bexiga" em terras do Barão de Limeira :

"A área do atual bairro do Bexiga, que compreende a região próxima à av. Paulista, tem remotas origens. Em 1559 estas terras perten ceram ao sítio do "Capāo", de Antonio Pinto, que recebia este nome devido à importante floresta multissecular que coroava o espigão ...Entretanto, a existêncià do nome Bexiga relacionado a um espaço geográfico é do período entre 1789 e 1792 . Em 1819, a chácara pertencia a Antonio Bexiga. Nela Saint Hi laire, o viajante francês, se hospedou por duas noites, em viagem a Sāo Paulo. Posteriormente, foi propriedade de Tomás luiz Alvares (Tomás Cruz), e por volta de 1850 foi vendida à firma Antonio José Leite Braga \& Cia. Imbuido pela febre de urbanização, que contagiava a metrópole no último quartel do século XIX, Antonio J.L. Braga promoveu a demarcação, abertura de ruas e iniciou a ven da de terrenos da chácara". (Lucena, p. 20) 


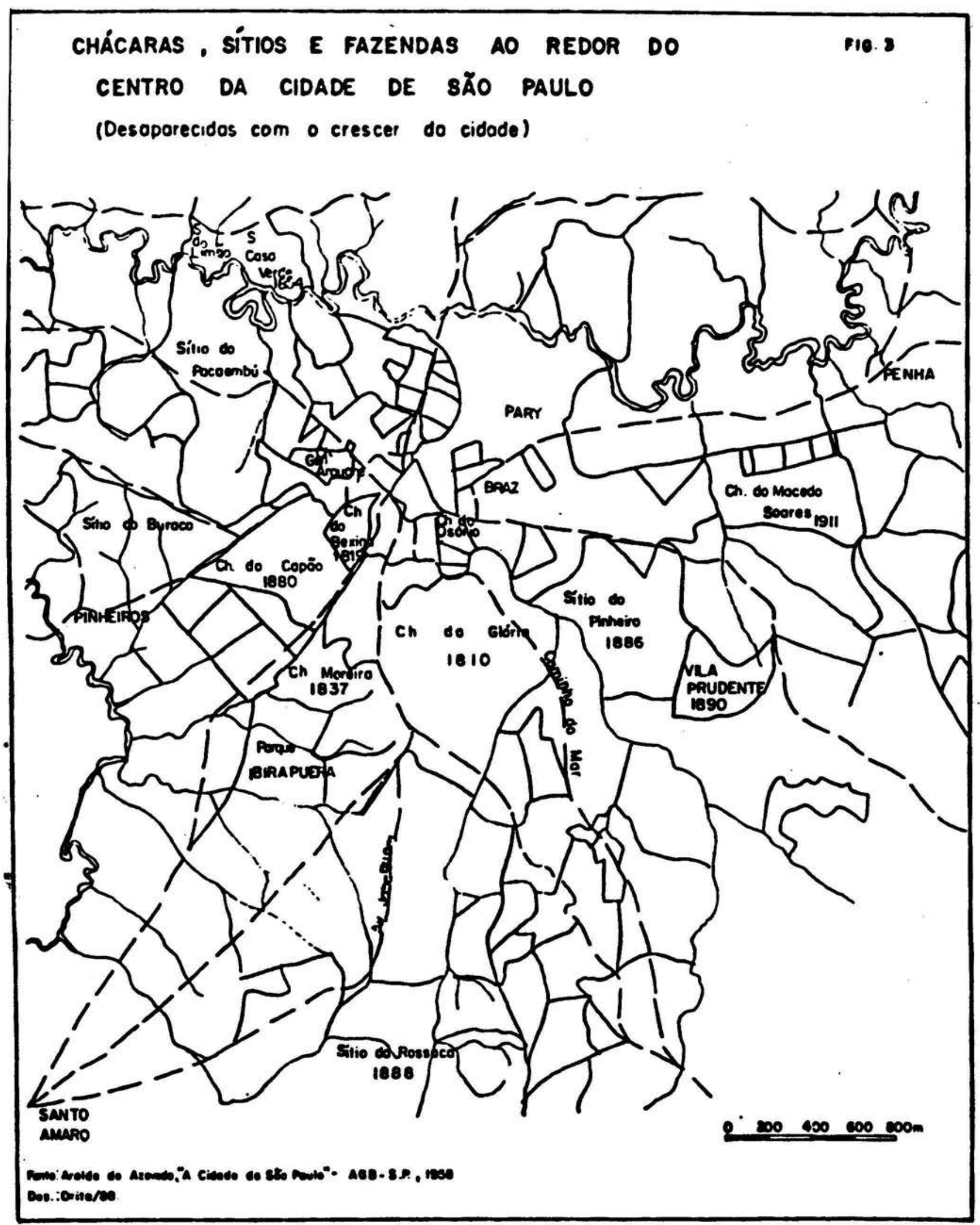


O Piques era o único lugar da "Chácara do Bexiga" segundo a planta, que apresentava sinais de ocupaçāo neste início de século $X 1 X$. Devemos lembrar que a atua) rua Santo Amaro, que já recebia este nome na época, importantc eixo de urbanização do bairro, compreendia, também, a área do Piques. Ai, segundo Saint-Hilaire, localiza va-se a hospedaria do proprietário da "Chácara do Bexiga". Assim, se colocou Saint-Hilaire:

"Entrei na cidade, a 20 de outubro de 1819 , por uma rua larga... Entraram os meus burros num pātio lamacento valado de um lado, cercado de outro por umas casinholas cujas portas abriram para este terreno, tantas quantas destinadas aos hóspedes. Bexiga alu gava o pasto mediante o pagamento de um vin tém (12 cêntimos) por noite e cabeça de ani mal, ficando o viajante dispensado de qualquer pagamento pela sua hospedagem". (SaintHilaire)

0 vazio urbano entre o "Alto Caaguaçu" e 0 "Saracura" contrastava com a tendência que a urbanização tomava em direção à rua da Consolação, outro importante ca minho em direção ao interior da província. Assim, o Piques, apresentava-se como um ponto de confluência das prin cipais rotas de ligaçāo da cidade. Daí saiam importantes caminhos de ligaçāo da cidade com o resto da província: a rua Santo Amaro, ligando a cidade ao litoral de Santos. Es ta rua também foi chamada de rua do "Curral", nela estava instalado o curral do Conselho que também servia de matadouro público, tendo sido citada em 1822 duas vezes: no mapa da cidade de São Paulo de Affonso A. de Freitas e na obra de Gaspar Bayron, intitulada "Ruas Principais de São Paulo". Além da rua da Consolação que ai se iniciava com 
- nome de largo da Memórja, tínhamos, também sajndo do piques, o "caminho do vaie do Anhangabaú" ou Caaguaçu. Outro importante vale era o Saracura, tributário do Caagaçu, que mais tarde, como já dissemos se transformou na atual av. Nove de Julho.

Até a segunda metade do século XIX, antes do grande crescimento que a cidade sofreria como resultado do surto do café, o bairro do Bexiga, hoje Bela Vista, resumia-se àquelas poucas edificaçōes da rua Santo Amaro e largo do Bexiga. A medida que se consolidou a economia do café e com ela o crescimento da demanda de mão-de-obra, re sultou na crise do trabalho escravo. As novas relaçōes de trabalho assalariado, após a segunda metade do século XIX impuseram-se, determinando toda uma política de estímulo à entrada de imigrantes para trabalharem como homens livres e assalariados. As novas relações capitalistas passaram a criar novos mecanismos no processo de urbanização estimu lando um intenso processo de especulação imobiliária. Iniciou-se, assim, em São Paulo a "anarquia urbana" capitalis ta :

"Dir-se-ia uma epidemia de urbanização, na opinião de Pierre Moonbeig, quando a cidade passa brusvamente entre 1890 e 1900 , de 65 mil para 240 mil habitantes. Crescendo repentinamente, um tanto ao sabor dos interes ses de vendedores de terrenos, a cidade carece, com urgência de um plano de urbanização: 'No norte da cidade, a epidemia de urbanizaçāo propagou-se a partir da Estaçāo da Luz, Santa Ifigênia, Campos Elíseos, Bar Funda e Bom Retiro desenvolviam-se tāo depressa como Brás. Os bondes Nothamnn e Glete em 1872, facilitaram-1he o acesso, melhor ainda, ofereceram aos fazendeiros, ter 
renos afostados no centro urbano para o esta bejecimento de um bajrto novo, de artérias bem traçadas, com verdadcitas avenidas e bas tante espaço para construir luxuosamente. conforme o fosto do dia; era o bairro dos Campos Elíseos, colonizado pelas melhores fa milias paulistanas. Ao longo e de ambos os lados as vias férreas abriram-se ruas popula res na Barra Funda e no Bom Retiro (18841886) pela reforma e prolongamento das ruas Helvétia e José Paulino. A conquista da Várzea encentou-se com as primeiras casas do $\mathrm{Pa}$ ri e do Canindé. Por seu lado, na margem direita do Tiête, o bairro de Santana conserva todo o seu ar camponês e quase não perturbava o seu isolamento". (Mendes Torres, p.111)

Neste surto de urbanização apontado por Monbeig, o bairro do Bexiga foi se estruturando. Segundo Cé1ia Toledo Lucena, (Bixiga - Amore Mio): "em 1878 teve inicio o processo de arruamento e venda parcelada de lotes (Jor nal da Província de São Paulo - 28/8/79 anunciava esta venda)". Nesta época, teve início o arruamento das ruas Santo Antonio (antigo vale do Anhangabaū), rua Major Quedinho, rua Major Diogo; rua 13 de Maio (antiga rua Celeste), rua da Aboliçāo (misericórdia), av. Brigadeiro luiz Antonio (como caminho para Santo Amaro) e da rua Martiniano de Carvalho (onde está hoje localizada a Vila Itororō). Em 1910, o bair ro do Bexiga jā estava caracterizado como um lugar de italianos.

Na obra de Ernani Silva Bruno é possivel encontrarmos indicadores que revelam a importância da localização do Piques para a circulação urbana de São Paulo. Estú dando os meios de transportes e caminhos na São Paulo colonial, assim se refere ao lugar: 
"A planta de Sĩo Paulo de $1880-1870$ de Afon so $A$. de Preitas assinalava a existencia de um pouso ou rancho, um pouco além da ponte do Ferrão, na futura av. Rangel Pestana ... Do outro no Bexiga...o do Bexiga e Lava pés, observou Vieira Bueno, que eram os mais frequentados por serem procurados pelas tropas que passavam para Santos. 0 pasto do primeiro desses ranchos era 'o do vas to esvalvado e acidentado campo do Bexiga' ... Em 1861 - pedia a municipalidade auxi lio ao governo da província para o prolonga mento da rua da Casa Santa (do Riachuelo) até o largo do Bexiga que podia ser conside rado continuação da estrada de campinas para Santos, 'evitando assim que as tropas transitem pelo centro da cidade'...Uma tentiva para diminuir a intensidade do tráfego de cargueiros na parte central da cidade que dava margem a tantas reclamaçōes." (SiI va Bruno, p. 597)

Esta posiçāo de entrada para a cidade permí tiu que aí se desenvolvessem as seguintes atividades:

"Ainda em 1877 eram realizadas, no largo do Bexiga, feiras de madeira... Acudiam nessas ocasições à cidade cerca de 300 carros de boi, conduzindo madeira, enquanto outros carregavam, também de Santo Amaro e de Itapecerica, lenha e pedra de cantaria... Além do local de feiras de madeira, e de pouso de tropas vindas do interior, no periodo de 1840 a 1860 o largo do Bexiga foi o local escolhido para o estabelecimento de companhias circenses ou de companhias de cavalinhos, muito frequentes na época... No 1argo, junto ao obelisco do Piques. rcalizaram-se uma vez por semana, concorridos leilōes de escravos... Ainda em 1830,toda a carne consumida na cidade de São Paulo, vinha do ma- 
tadouro existente na ladefra de Santo Amaro... I:m 1852 injciou-sc a construção de um novo matadouro, entre as ruas Humaitá c pitangui... O matadouro não demorou por ali senāo um quarto de século, até 1877 . pois continuava poluindo o córrego do Anhangabaú, - que fez com que a Câmara Municipal resol vesse acabar com esse matadouro e construir um novo em Vila Mariana..." (Marzola, p. 52)

O processo de urbanização do Bexiga teve efe tivamente seu início a partir de 1880 , como tivemos oportunidade de registrar pelo anúncio no Jornal da Província de São Paulo de 28/8/89, quando começaram os loteamentos e arruamento do bairro. Acabava na cidade de São Paulo o "ciclo dos trovadores para começar o da indústria". "Caiam as rótú las, as mantilhas, arruavam-se o Campo do Chā, 0 Bexiga". I niciavam-se para a cidade e para o bairro, grandes transformaçōes. Até 1912, o bairro guardou. o nome do Bexiga; a partir de então passou a chamar-se Bela Vista criando grande celeuma entre seus moradores.

\subsection{Dos Primórdios à Primeira Metade do Século XX}

Pela análise de Caio Prado Jr. os bairros de São Paulo cresciam sem qualquer plano de conjunto, como obra do acaso, como fruto de especulaçōes com terrenos. Uma das intervençōes públicas importantes, para mudanças no per fil arquitetônico da cidade, foram as disposiçōes do Código de Posturas de 1875, proibindo construçōes de casas de meia água e do sótāo de cumieira para frente. Assip na cidade,pe la riqueza do café e com a entrada de imigrantes italianos. os "capomastri", como māo-de-obra qualificada"para a nascen 
tc indústria da construsão civil, cresceram os sobrados c palacetes aristocráticos. Para construção de muitas casas novas, contaram os moradores de São Paulo com a colabora çāo de arquitetos e empreitciros italianos. A expansão urbana acelerada de São Paulo criava um quadro difuso, pouco harmonioso: "...essa falta de estilo harmônico não produ zia boa impressão" - escrevia Maurício Lamberg em 1887." (Silva Bruno, p. 930)

São Paulo assumia ares de cidade européia. principalmente italiana: "O tipo comum de construçōes - as sinalava em 1894 o viajante Mácola - era os das cidades italianas das províncias" (Idem, p. 933).

O crescimento econômico e a consolidação das novas relaçōes capitalistas na cidade fazia da mesma a expressāo da segregação espacial do sistema. Os bairros cresciam demonstrando a dominação de classe. Bairros elegantes em constraste com os bairros proletários de "beira de estrada". A ferrovia criava ao longo do seu trajeto indústrias e vilas operárias. O Brás, Barra Funda, Ipiranga, Moóca, etc, foram profundamente marcados pela expansāo fer roviāria. Passaram a ser caracterizados tipicamente como bairros proletārios.

Em 1910, inaugurava-se o bairro do Jardim América. A av. Paulista jā haviạ hả poucos anos, sido inaugu rada. O rápido crescimento dos bairros ao redor do centro da cidade, vinha sendo acompanhado por profundas transformaçōes neste centro: "Silva Teles achava $\underset{>}{\text { em }} 1907$ um absurdo que ao lado do futuro Teatro Municipal - que ficaria pronto dentro de poucos anos - se estendesse "uma fila repugnante de fundo de velhas casas e primitivas habitaçōes". 
(Silva Bruno. p. 952). A segregaçäo como pode set vista não cstava somente na produção espacial mas também no discurso da classe dominante.

Concomitante ao crescimento destas áreas aris tocráticas como a av. Paulista, Higienópolis, Brigadeiro Luiz Antonio (estando esta ültima incorporada hoje ao Bairro da Bela Vista), cresciam, também, os bairros modestos e proletários. O Bexiga era já um destes: "...nenhum conforto - escrevia Bandeira Jr. em 1901 - tem o bairro proletário. nesta opulenta e formosa capital... Casinhas e cortiços, sobretudo os do Brás e do Bexiga..." (Idem, p. 956). 0 Bela Vista, herdeiro do Bexiga, no seu processo de expansão acabou incorporando espaços muito diferenciados. A avenida Brigadeiro Luiz Antonio apresenta, mesmo que de forma descontí nua, a presença de velhos casarōes, antigos sobrados cujas fachadas e varandas ladeadas por jardins, demonstram terem pertencido a classes sociais de alto poder aquisitivo. Áo longo da rua Santo Antonio, Major Diogo, av. Brigadeiro Luiz Antonio etc, existem testemunhos de um patrimônio arquitetônico que demonstra um descompasso em relaçāo à̀ tendência geral de ocupação do bairro.

o Bexiga, pela posiçāo geográfica em l que se encontrava no conjunto urbano, desde o final do século passa do e primeiras décadas do atual, acabou guardando uma nature $2 a$ difusa quanto às formas de uso do solo e estilos arquitetônicos. Eṇquanto o núcleo histórico do Piques já existia nesta parte baixa ao longo do Anhangabaú, as partes das colí nas, mais ao sul, continuaram por muito tempo totalmente des povoadas (Fig. 4). A ocupaçāo destas últimas foi feita pelas classes mais aristocräticas de São Paulo. Em 1894, foi aber- 
P10. 4

planta da cidade de são paulo

1881

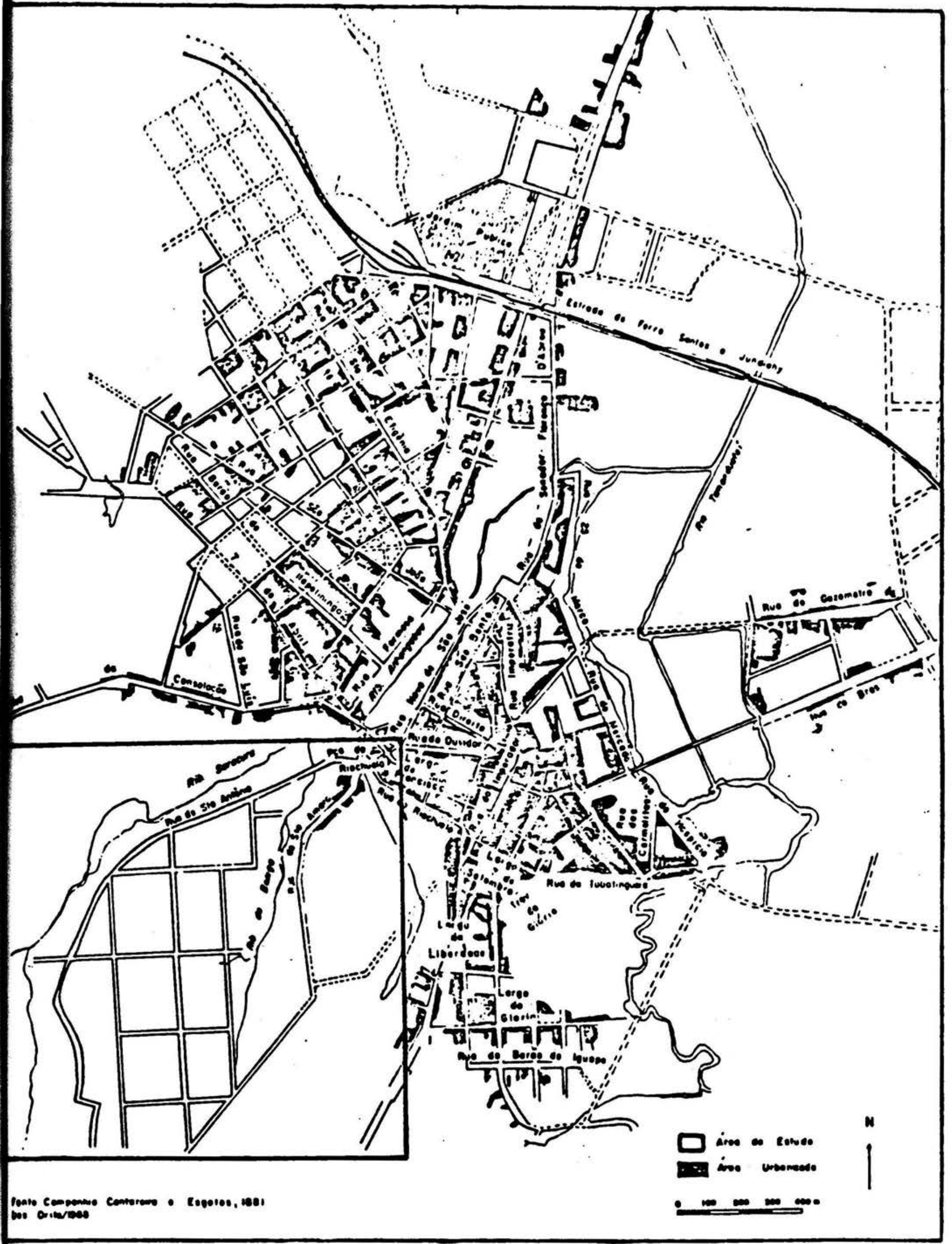


ta av. Brigadeiro lujz Antonio nas terras da chácara do Barão de limeira:

Lm 1891, as tahclas para carros e tilburis ainda mencionavam algumas chácaras que serviam de limite às zonas ou seçōes dentro das quais se cobravam certos preços, como para a chácara do Dr. Albuquerque, no Bexiga..." (idem, p. 1030).

A presença desta aristocracia que passava a ocupar os grandes vazios do bairro ainda pode ser testemunhada por algumas edificaçōes sob a proteção da 28-200, a exemplo dos palacetes situados na av. Brigadeiro Luiz Anto nio no $n$ 9826 e outro na esquina da mesma av. com a rua Humaitá, além de outros em elevado estágio de deterioração e descaracterização das fachadas, assim como aqueles que foram demolidos, entre eles, o velho palacete na esquina da av. Brigadeiro Luiz Antonio com a rua dos Ingleses. 0 da esquisa da rua Humaitá, conforme pode șer comprovado no seu frontispício, data de 1908. Na mesma avenida, com carạ terísticas arquitetônicas mais modestas, encontramos, tam bém, outra residência com data de 1905. Esta ūitima quase na esquina da av. Paulista. Assim, podemos chegar a conclu sāo de que a parte interna do bairro, aquela que se estendia entre o alto Caaguaçu, o ribeirāo Bexiga, tributārio do Caaguaçu, e o ribeirão Saracura jā se encontrava em acelerado processo de urbanização. Alguns dos casarōes encontra dos na altura das ruas Conselheiro Ramalho, Manuel Dutra . Fortaleza,'Major Diogo e Treze de Maio, em lugares, portan to, bem distantes entre si, datam deste inicio de século. Como dissemos anteriormente muito destes casarōes demons tram terem sido construidos por familias que representavam 


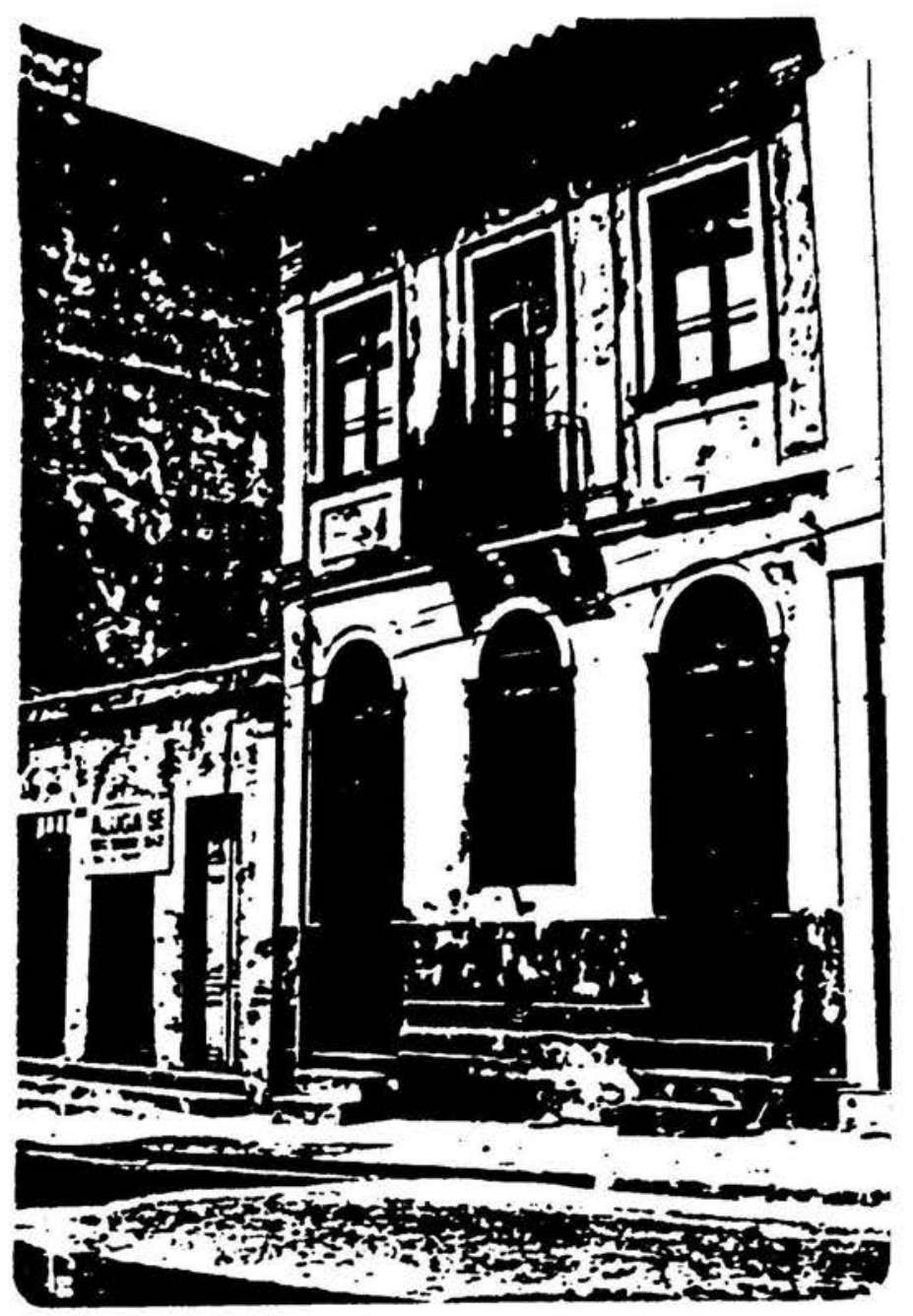

Foto 1: Casarão localizado na rua São Domingos, datado de 1889. Arquitetura que testemunha a ocupaçāo italiana naquele final de século. (Ano: 1988) 
uma elite dentro da árca, caso do casarão da rua Major Diogo $n^{4} 353$. Para o mesmo foj fejta a seguinte. referencia histórica:

"Residencia que foi propriedade da familia Mel10 Freire, datada de 1907 , obra de "capomastro", que, na verdade, representou na épo ca uma solução elitista ligada aos partidos das velhas chácaras de arrabalde, com sua va randa lateral intimamente ligada a um jardim recortado em pequenos canteiros simétricos. Uma das mais antigas residências do bairro deve ser conservada, antes de tudo, pela sua representatividade." (Bens Culturais Arquitetônicos no Município e na Regiāo Metropolitana de São Paulo, p. 232).

Caso também do situado na avenida Brigadeiro Luiz Antonio, 826:

"Residência projetada por Giuseppe Sachetti para Cláudio Souza, proprietário da Vila Eco nomizadora. Construida de 1907 a 1911, possui movimentado frontispício... criando uma complexidade típica Art Nouveau... Este exem plar também foi objeto da fúria demolidora de seu proprietário, fúria só a muito custo contida com o auxilio de força policial. Todavia o imóvel ainda está ameaçado, pois embora listado como bem cultural na Lei $n^{\circ}$ $8328 / 75$ (que infelizmente é desprovida de instrumentos legais que garantam efetivamente a preservação desses bens) e tombado pe10 CONDEPHAAT, teve, logo em seguida seu tom bamento incimpreensivelmente cancelado".

(Bens Culturais Arquitetônicos no Município e na Regiāo Metropolitana de São Paulo, p. 233).

Estes dois exemplos, além de revelarem a pre sença daquela parcela de aristocracia dentro do bairro, documentam, mais uma vez a contribuiçāo italiana com seus 
"capomastrj" para a construção do mesmo. De carăter bem modesto e bem distante dos dols prédios acima mencionados, te mos um localizado na bifurcação da rua Santo Antonio com a rua 13 de Maio. No frontispicio do mesmo está registrada a data de 1905. Assim, torna-se difícil duvidar que o Bexiga, neste início de século, já se encontrava povoado na sua maior parte. Devemos considerar, também, que o "Velho Bexíga" parece não ter sido somente, como escrevia Bandeira Jr. um bairro de "casinhas e cortiçoes", mas um bairro com quaùro urbanístico e arquitetônico "difuso e pouco harmonioso". colocando-nos mais próximo daquela observação feita por Maurício Lamberg em 1887. Mesmo considerando que aquele autor tenha se baseado na paisagem arquitetônica da partè baixa da rua Santo Antonio ou da rua Santo Amaro na sua época,tor na-se difícil aceitar a generalização feita ao Bexiga de um bairro de "casinhas e cortiços". As casas existentes nes tas duas ruas neste início de século, apresentavam-se como casas térreas ou sobrados, ocupadas por uma classe social que estaria muito perto daquelas que hoje chamamos de "clas se média baixa" e onde poderíamos ver o trabalho arquitetônico, cuidadoso e artístico dos "capomastri".

O bairro cresceu dentro de um processo desen freado e sem qualquer plano ordenado de espaço. Na verdade, as únicas áreas do bairro que apresentam uma unidade no padrão das suas construçōes, em função do momento histórico da sua integraçāo ao bairro, sāo oalto da Grota e do Espigãọ ambas de ocupaçāo mais recente e por uma população de maior poder aquisitivo. A ocupaçāo destas duas áreas se fez seguindo os padrōes dos novos bairros jardins do início do século, sustentado pela "ṇova burguesia urbana" e por uma emergente e "próspera classe média". Este crescimento este- 
ve ligado à onda de especulação imobiliáría que invadiu a cidade naquele final de século. Queremos, aqui, mais uma vez, invocar Célía Toledo Lucena:

"Assin, A Província de São Paulo, em 23 de junho de 1878, anunciava: 'Vendem-se por propostas todas as matas dos terrenos do Bexiga, pertencentes a A.J.L. Braga \& Compa nhia - os pretendentes podem examinar desde jā. A.J.L. Braga \& Comp.' '...A firma Antonio José Leite adquiriu os terrenos de Tomás Luís Alvares, em meados do século XIX e a partir de 8 de maio de 1878, A Província de São Paulo publicava anúncios do loteamen to dos pastos do Bexiga. Braga deixou seu nome marcado no processo de urbanização da ārea...'Nessa febre de urbanizaçāo, os anún cios se repetiam: 'Terrenos para todas as bolsas: Terrenos muito bem situados nos cam pos do Bexiga, vendemos às braças ou mesmo em lotes, com matas ou campos, à vontade do freguês e por preço sem concorrência. Tem várias fontes de água pura, lindos panora mas e ar saudāvel. Ruas de 60 palmos de lar gura. Preços baratíssimos. Desde 20 até 50 mil réis a braça, todos com trinta braças de fundo ou mais. A planta se acha nas oficinas de móveis Santo Antonio, no Bexiga. Tratar com os proprietārios na mesma oficína, Sr. José Leite Braga. Aproveitem o preço:' (A Província de São Paulo, 27/6/88"), (Lucena, p. 32).

Segundo a planta da Capital do Estado de São Paulo publicada por Jules Martin (Fig. 5) em 1890, o Bexiga $j a ̄$ apresentava um traçado urbano bem prōximo do atual. Suas principais ruas jä estavam traçadas. A forma em "tabuleiro de xadrez" com suas quadras em ângulo reto domí nava toda a área compreendida entre a Grota e o ribeirāo 
planta da cidade de são paulo

1890

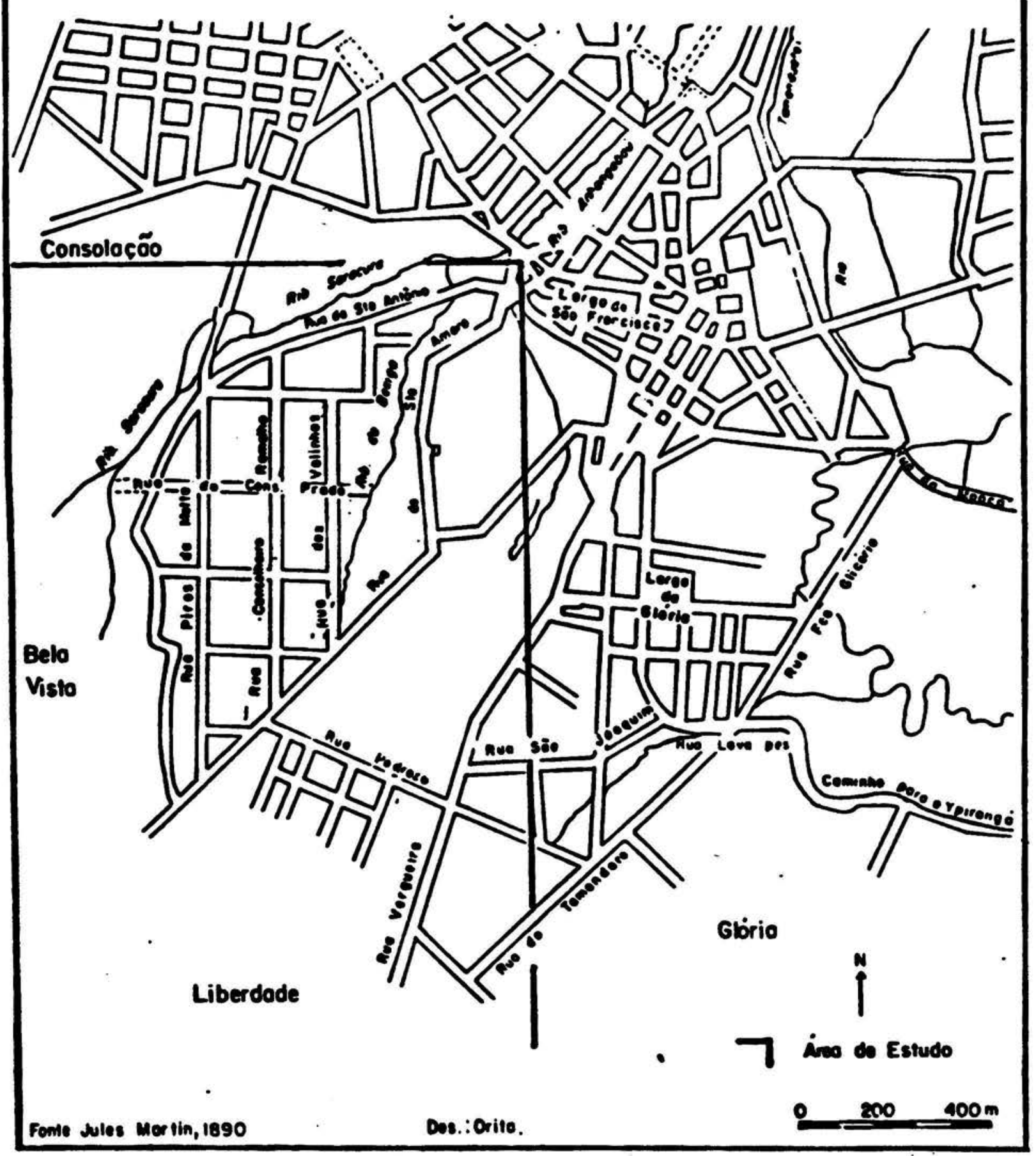


Bexiga que permanceiam ajnda desocupadas. O arruamento ing cial do bairro se fez sobre as partes mais aplainadas daquelas colinas. A zona do espigão também continuava vazia. As ruas que aparecem na planta de Jules Martin que marcam o inicio da urbanização do Bexiga, foram ocupadas por lotes de testadas estreitas, raramente ultrapassando 10 metros, porém, apresentando fundos muito longos em relação às fren tes estreitas. Estas quadras acabaram sendo pulverizadas por pequenos loies em funçāo das "bolsas mais pobres" que passaram a ter acesso a este loteamento. Os italianos, que nesta época eram os imigrantes que mais entravam em São Paulo, foram os que passaram a dominar o processo de ocupa ção destas quadras. Os "capomastri", homens sem diploma que aprenderam o ofício como herança de pai para filho, que desenhavam na terra, com a ponta do guarda-chuva, as plantas das casas que construíam, deixaram suas marcas no perfil urbanístico do bairro e de outras localidades da cidade. A quantidade de italianos que afluiu para Sāo Paulo en tre 1882 e 1891 foi muito grande. Segundo registro da Sociedade Protetora de Imigrantes da época, dos $263.196 \mathrm{imi-}$ grantes que entraram entre aquelas datas - 202.503 eram italianos. Portanto, o período de colonização e loteamen tos das terras do Bexiga coincide com um período de intensa imigraçāo italiana. Aqueles que chegavam a São Paulo e dispunham-se a comprar algum terreno viam-se fascinados pe las ofertas das terras no Bexiga. Obviamente que não se dí rigiram somente para este bairro: o Bräs, a Barra Funda, tambēm receberam estes imigrantes. Para o Bexiga foram dominantemente os calabreses, na tentativa de formarem sua comunidade. Segundo depoimentos feitos por antigos moradores, a chegada era sempre precedida de uma relação com o 
compatriota no exterior, ou entũo, quando aqui chegavam, buscavam localizar-se junto daqueles que falavam o mesmo dialeto e tinham o mesmo lugar de origem. Assim, entre o "Baixo Piques" ou o "Velho Largo do Bexiga" e a atual rua Fortaleza, limite mais extremado ao sul das "colinas do Bexiga", os italianos ocuparam seu pedaço.,

Em poucos anos o Bexiga foi incorporado à grande mancha urbana de São Paulo, fazendo parte de uma das áreas mais centrais da cidade. Observada a Planta Geral da Capital de Sāo Paulo, organizada sob a direçāo de Gomes Cardim de 1897 (Fig. 6), o bairro do Bexiga já estava "encravado" dentro do, tecido urbano paulistano. 0 único espaço praticamente vazio era a região da Grota, devido a dificuldade em lotear-se a área em função do seu relevo muito ingrime. 0 alto do Espigão, da rua Sāo Carlos do Pinhal até a al. Jahú jā se encontrava urbanizado. 0 Vale do "ribeirão Bexiga" (hoje ocupado pela rua Japurā e sobre - qual está construída a Câmara Municipal de São Paulo), que na carta anterior ainda aparecia como um vazio urbano, nesta ūltima, aparece $j a ̄$ incorporado ao arruamento do bair ro. O Morro dos Ingleses, ainda não estava ocupado. Este "Belvedere" paulistano, em cujas encostas estendia-se a rua 13 de Maio, foi uma das últimas áreas do Bexiga a ser ocupada. A sua ocupação foi feita, assim como toda a área do espigão, por uma classe social de alta renda, o que per mite compreender a discriminação existente entre estas duas regiōes pelos antigos moradores do bairro.

O Bexiga emergia, ocupando as colinas terciārias de Sāo Paulo, fugindo dos fundos de vārzeas, constantemente inundadas. Para Maira Cecilia Naclério Homem 
PLANTA dA CIDADE dE SÃo PAULO

\section{7}

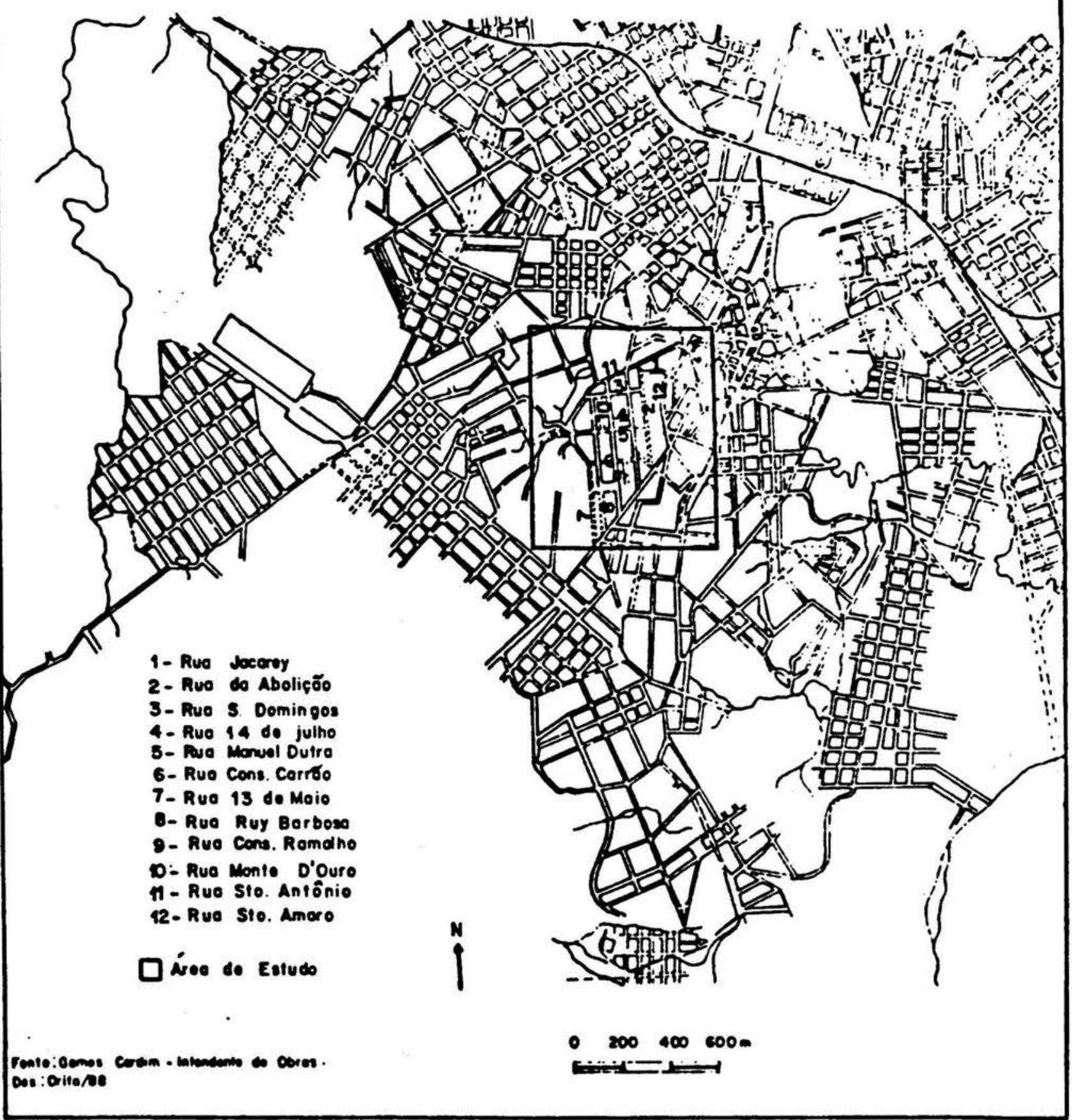


esta ocupação aconteccu da scguinte forma:

"A elite paulista ocuparia gradativamente a zona Deste da cidade numa trajetória que incluiu Higienópolis. Este viria a ser exatamente o primeiro degrau de sua ascensão rumo à av. Paulista... Enquanto mais próximo do centro, no sopé do espigão, antigas chácaras cediam lugar a bairro médios como a Consolação, Santa Cecília, Vila Buarque e a Liberdade e no alto do espigão, a Vila Mariana. Higienópolis surgiu na encosta do mesmo, numa sequência dos Campos Elíseos. E, subindo sempre, as residências alcançaram o alto do Espigão, onde se instalam, acompanhando fielmente a av. Paulista. Já então a progressão cafeeira se interrompera, as novas fortunas saem da indústria e do comér cio quase todo em mãos de estrangeiros, imi grantes enriquecidos nesta Canaã americana: a Avenida Paulista será o bairro residencial dos milionários desta nova fase da econo mia paulista, estrangeiros ou de recente origem estrangeira quase todos... Quanto aos bairros industriais e operários formaram-se nas terras mais baixas, das várzeas dos rios Tietê e Tamanduatei o que foi propicia do pelo custo inferior das terras e pela presença das ferrovias, as quais promoveram a organização do espaço naquela parte da cidade..." (Naclério Homem, p. 24).

Assim, o capitalismo e a sociedade de clas ses davam os contornos nas formas de uso do espaço urbano. As pessoas se acomodavam aos lotes e passavam a definir a estética e a qualidade das habitaçōes em funçāo das suas rendas. Nos bairros aristocráticos, fazendeiros e industriais construiam grandes palacetes seguindo os modelos e plantas trazidos da Europa. Falando sobre a construçāo do palacete de D. Veridiana no Bairro de Higienópolis, assim 
se coloca a a tora Maria Cecilia Naclérjo Homem:

"1). Veridiana vinha de sua chácara na rua da Consolação... Em 1877 separou-se do marido... No ano seguinte adquiríu o terreno de Sta. Cecilia onde construiria em 1884 um palacete... Trouxe a planta da Europa, em est 10 Renascença francês, a qual foi construída pelo engenheiro Luiz Liberal Pinto com material todo importado..."

Estas informações a autora obteve do histo riador J.F. de Almeida Prado (ou Yan de Almeida Prado) descendente de uma das mais tradicionais familias de São Paulo. Assim também procedeu a familia Alvares Penteado. Estas tra dicionais familias paulistas, seus descendentes e amigos acabaram povoando aqueles bairros da zona oeste da cidade,as sim como o espigão.

Para o bairro do Bexiga, ocupado por traba lhadores imigrantes, artesãos, o contorno foi outro. Ao invés do isolamento dos grandes palacetes, contornados por enormes e esplêndidos jardins, onde a rua ficava do "lado de fora" da casa, procurava-se alinhar as casas diretamente para a rua. Porém, segundo Nestor Goulart, significativas mudanças passaram a ocorrer com aquelas residências alinhadas diretamente para a rua:

"Um novo tipo de residência, a casa de porāo alto, ainda 'de frente da rua' representava uma transição entre os velhos sobrados e as casas térreas...a nova fórmula de implantaçāo permitiria aproximar as residências da rua, sem os defeitos das térreas, graças aos porōes mais ou menos elevados... Nosso caso. para solucionar o problema do desnivel entre - piso da habitação e o plano do passeio,sur gia uma pequena escada, em seguida a porta de entrada. Após a escada, a proteger a intí midade do interior da vista dos passantes... 
lisse tipo, que representava uma renovaçio, dentro dos velhos moldes construtivos, teve larga difusão... Com esses traços al inhavamse nas ruas Santo Antonio e Santo Amaro, em São Paulo... (Reis Filho, p. 40).

Esta opção pelas casas de porões altos que caracterizou a maior parte das casas do Bexiga, veio permitir a exigência de uma forma de vida onde casa e rua forma vam um espaço psicológico integrado. Ao mesmo tempo que - porão, elevando o "para-peito" das janelas a um nível que impedia ao transeunte avistar o interior da residência, pre servando a intimidade da familia, permitia, também, ao mora dor desfrutar do prazer de acompanhar os acontecimentos sociais que ocorriam na rua. Esta modalidade de habitação,que se propagou em grande parte pelos bairros de São Paulo, no Bexiga, passou a definir um traço cultural do mesmo. Confor me podemos observar na foto contida no início do livro de Nadia Marzola - Bela Vista - uma das antigas moradoras do bairro, Dona Antonieta, "deleitava-se em acompanhar tudo o que acontecia no pedaço, sempre apoiada sobre sua almofada"um relicário de família" disputado inclusive pela filha, am bas permanentes observadoras daqueles acontecimentos. Assim como Dona Antonieta, outras pessoas se perpetuaram na memória de seus moradores como "eternos vigilantes" das ruas do Bexiga. As ruas, prolongamentos naturais das casas, permí tiam um convívio estreito. As pessoas se comunicavam pelas janelas, fosse com aquelas que passavam pelas ruas, ou então, com outras em janelas mais distantes. A estrutura do Bexiga na sua maior parte em tabuleiro de xadrez e a inexis tência de praças, nāo fazia do bairro, como muitas vezes se apregoa, um espaço tão acolhedor. 
pequenas vilas em ruas sinuosas na verdade cram muito poucas no bairro. Enquanto o automóvel não havia invadido este espaço, as ruas desempenharam bem o papel acolhedor representado pelas praças. Ao longo diquelas ruas era comun: as pessoas colocarem mesas e cadeiras demonstrando estreitos vínculos nas relações de vizinhanças. Enquanto o espaço casa e rua estreitava as relaçōes entre as pessoas permitindo um convivio de grande intimidade no Bexiga, outras se isolavam nos grandes palacetes circun dados de jardins nos bairros aristocráticos. As relaçōes de vizinhança nestes ūltimos, estiveram sempre revestidas de grandes formalismos.

No Bexiga, um bairro mais humilde, observamos que aquelas classes de menor poder aquisitivo e distan tes do poder politico e econômico representado pelos habitantes daqueles bairros aristocrāticos, também deixaram suas lembranças registradas através do patrimônio arquitetônico do mesmo. Eram detalhes decorativos e medalhōes colocados nos frontais das casas, vasos e estatuetas, janelas com bandeiras com vidros coloridos, balcões e portões com ferro artisticamente trabalhados que, além dos enfei tes decorativos serviam, tambēm, para denotar a importân cia do seu proprietário. Estes balcōes, nos dias de festas do bairro, davam um ar de nobreza para aqueles proprie tários. Tudo isto demonstrava a necessidade de uma classe que também se preocupava em firmar sua identidade nas formas de uso do espaço, onde este todo, apesar da descontinuidade de estilos e efeitos decorativos, criava um clima romântico que preservava a escala humana entre os espaços interiores e exteriores na interação casa e rua. 
conjunto de casas sobrados, sem grandes ajtitudes c imposigño de grandes massas de concreto, permitia ao morador ví ver um espaço onde o interior exterior destes espaços se harmonizavam.

Pelos idos de 1950, o bairro guardava ainda caracteristicas que lembravam as primeiras décadas do sécu10, das casas de testadas estreitas e quintais longos, se podiam ainda observar lembranças das antigas chăcaras: eram jabuticabeiras, abacateiros, grandes taquarais, hortas, que muitas vezes levavam à prática de uma "economia de trocas", fortalecidas pelas relaçōes de vizinhanças, lembrando muito comportamentos de bairros rurais, remanescência de uma tradição do bairro dos fins do século passado, quando os acadê micos de direito procuravam o Bexiga, atraídos por estes po mares e pelo bucolismo de uma vida rural. Não raro, encon trávamos estábulos pertencentes aos "carroceiros" que viviam da venda de frutas e verduras pelas ruas do bairro e da cidade. Ao longo da rua Treze de Maio encontravam-se alguns destes estábulos, lembrando muito os costumes a paisagem de lugares daqueles contadinos que trouxeram para o Bexiga a marca da sua cultura, que para nós acabou se resumindo na expressão "carroceiros", usada muitas vezes pelos da terra com tom pejorativo.

Apesar da expansão urbana acelerada de São Paulo, buscando limites cada vez mais distantes do velho centro, criando uma periferia desordenada pelo impulso da exploração imobiliāria do solo urbano nesta primeira metade do século XX, fato que se acentuaria a partir dos anos cinquenta (Fig. 7), muitas áreas do Bexiga e demais bairros do entorno ao centro, encontravam-se vazias. No Bexiga tí- 
BELA VISTA_EVOLUÇĀO URBANA E ${ }_{54}$ TRANSFORMACరESS.

F167

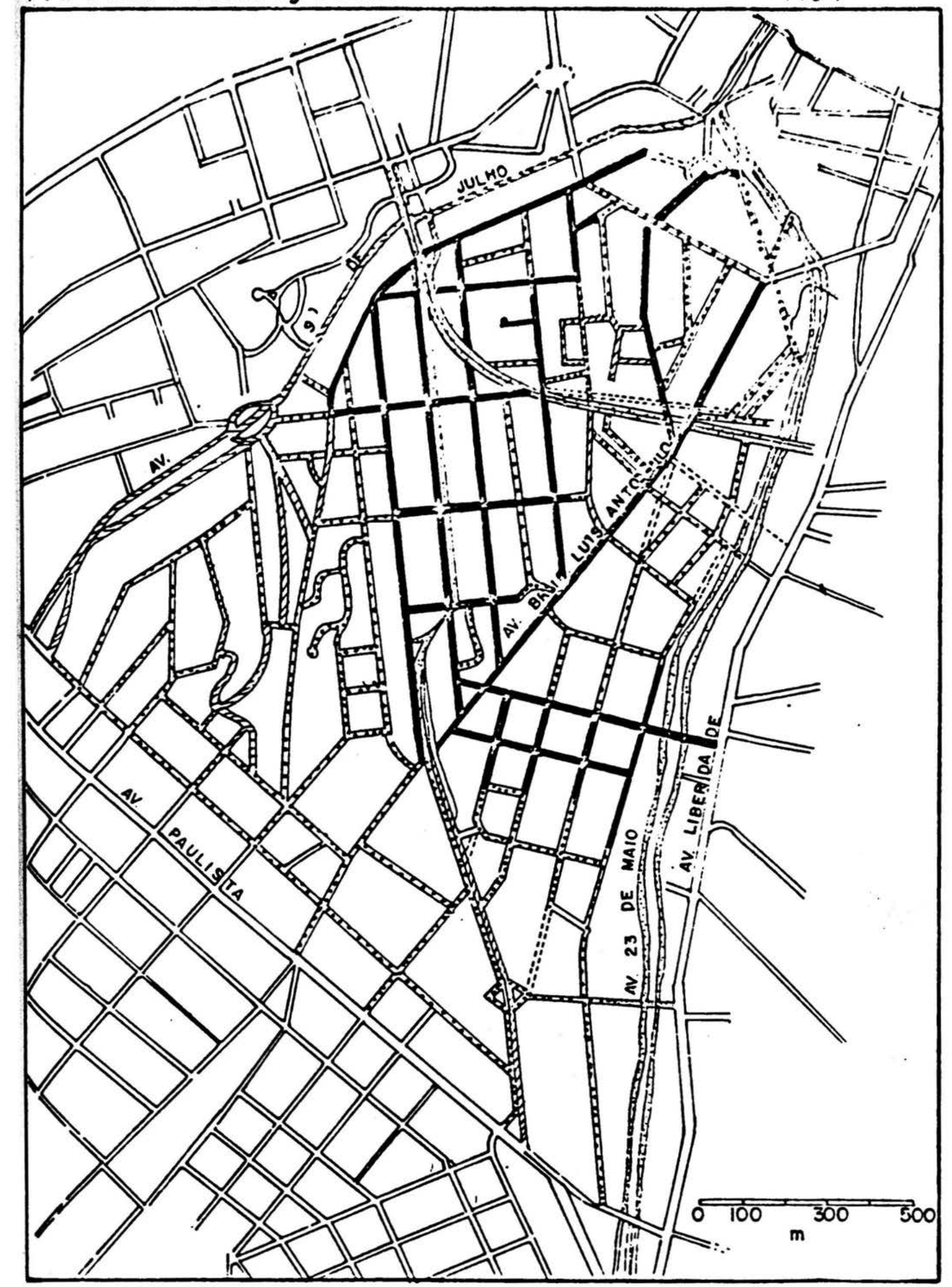

1870 (fonte:mopos do IV Contenório)

\%: 1930 (fonfo: mopo Soro)

1954 (fonte:mopo - VASP)

1972 (fonto: GEGRAN)

Des.:Orifo. 
nhamos o excmplo da regiño da lirota. Outras árcas bem mais ao centro permancciam vazias até os anos cinquenta. A av. Nova de Julho, aberta pelos anos quarenta ao longo do vale do "Saracura Grande". permancciam com grande parte das suas encostas ocupadas por uma vegetação de campo. 0 alto do vale do Anhangabaú (alto Caaguaçu) onde hoje está construída a av. 23 de Maio, permanecia ocupado por chácaras.

A introdução da ferrovia em São Paulo na segunda metade do século passado contribuiu para alterar as funçōes de muitos bairros da cidade. O Bexiga acabou perden do sua importância como ponto de passagem para Santos e interior da provincia. As indústrias que se instalavam em São Paulo davam preferência às áreas próximas das ferrovias, co mo caso a Barra Funda, Móoca, Ipiranga e Brás. 0 Bexiga abrigou muito poucas indústrias; indústrias como as serrarias, matadouro e oficina de móveis que ocupavam o "Largo do Bexiga".

Nas primeiras décadas deste século, as principais indústrias do bairro eram as seguintes: uma indụstria de chapéus localizada numa travessa da rua Santo Amaro, na atual travessa Noschese. Dela restaram como testemunho o edificio onde estava instalada, hoje ocupado por um estacio namento e a vila de casas operárias, mandada construir pelo industrial Noschese en 1912; a indústria têxtil localizada na esquina da rua Fortaleza com a Conselheiro Ramalho, da qual temos hoje somente o antigo prédio que já foi ocupado para diversas finalidades, sendo usado atualmente por uma oficina mecânica; e por último, a indústria Scatamachia de calçados, também desativada, estando suas instalaçōes hoje ocupadas por uma empresa de serviços. Esta última indústria 
estcve localizada na rua Major Diogo, próxima ao Teatro Bra silcito de comédia, em frente a mais antiga cantina do baí ro, a cantina Capuano. Fora destas indústrias, o bairro somente conheceu a presença de pequenas fábricas de móvcis, gráficas, alimentos, confecçōes e mais algumas de calçados e serralherias. O Bexiga ficou, pois fora dos espaços ocupa dos pelas grandes indústrias de São Paulo, definindo-se mais como bairro residencial, seguindo a tendência da maioria dos bairros da cidade que se localizavam distantes das ferrovias. Ernani Silva Bruno, assim, nos lembra:

"Em fins do século passado mostrou Cassio Mo ta que o comércio deixava muito a desejar "era pequeno e muito espalhado, não satisfa2 ia a necessidade da população. Os bairros eram quase noventa por cento residenciais... 0 alto comércio, "comércio para todos" escré via ele, era no centro que se condensava".

(Silva Bruno, p. 1.168)

Além da distância das ferrovias, sua proximí dade com o centro contribuiu bastante para definir as formas de uso do solo do bairro. O Bexiga ficou à margem da grande ocupação industrial e comercial. As poucas que ali se instalaram foram de pequenos empreendimentos. As oportu nidades de terrenos baratos e abundantes próximos às ferrovias, além das vantagens que o sistema ferroviário apresentava para os empreendimentos industriais, impediu que 0 bairro as transformasse em lugar de indústrias e vilas operärias. A preferência foi para aquelas regiōes próximas às ferrovias, ou entāo para as partes baixas da cidade, onde os terrenos mais baratos atraiam aquelas formas de uso. As necessidades da população em serviços e comércio eram atendidas basicamente pelo centro da cidade. A proximidade com - mesmo permitia que as pessoas facilmente se dirigissem 


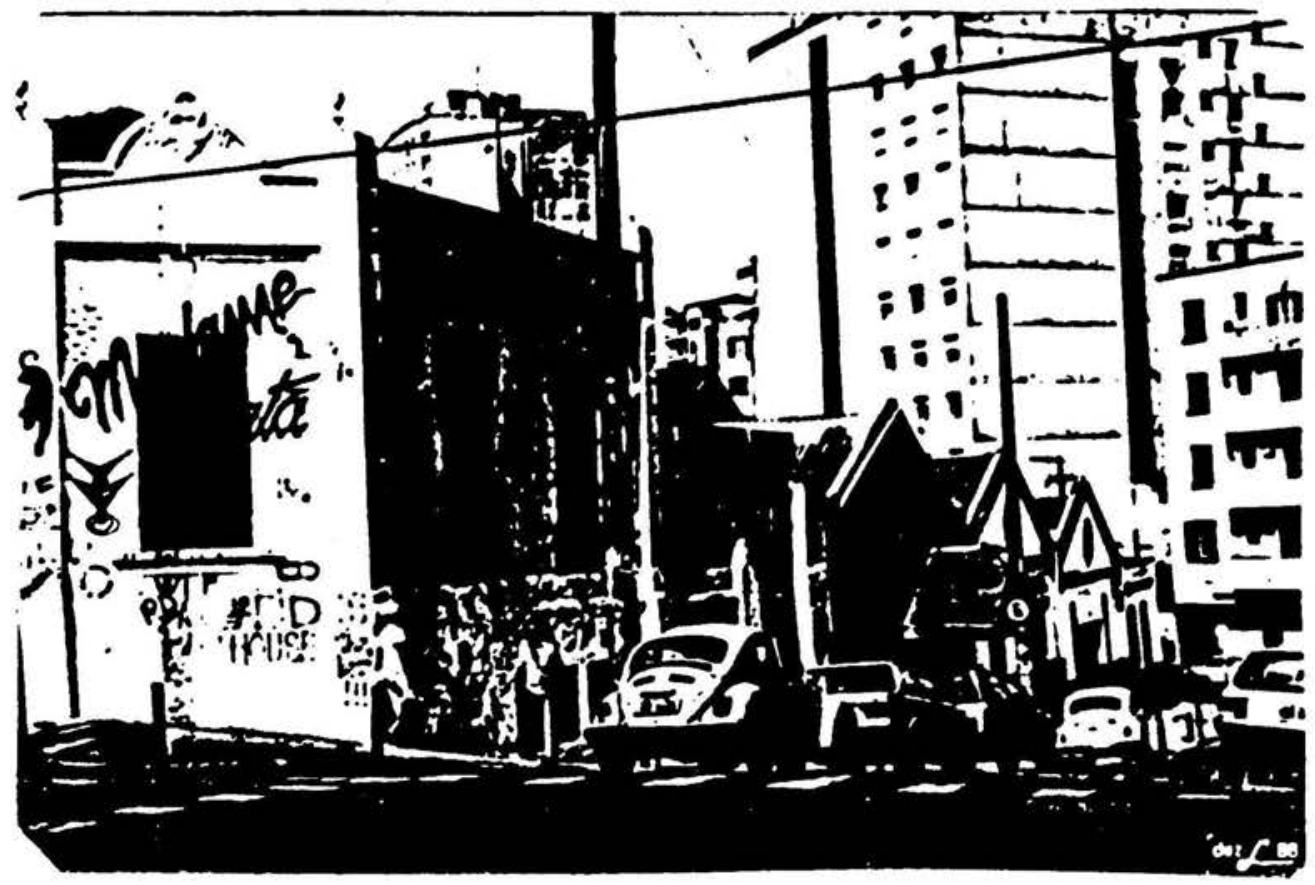

Foto 2: Edifício localizado na esquina da rua fortaleza com a rua Conselheiro Ramalho. Este edificio foi ocupado no inicio do século por uma indüstria têxtil. Atualmente é ocupado por uma casa de diversão noturna e uma oficina mecânica. (Ano: 1988) 
até ál, a pé ou de bonde. Esta proximidade não somente favo recia o atendimento àquelas necessjdades como também fuvore cia a possibilidade de emprego no comércio e nos serviços. o trânsito a pé entre o centro da cidade e o bairro era mui to grande. Transeuntes e "sentinelas de janclas". marcados pela rotina do cotidiano nestes roteiros entre residência e trabalho, acabavam criando um clima de familiaridade e cortesias, traço marcante na cultura deste bairro que acabou por se perder com as transformaçōes sofridas posteriormen te.

Aqueles que não iam procurar trabalho no cen tro exerciam atividades de pequenos negociantes ou autôno mos, prestando serviços de consertos. Eram geralmente alfaiates, proprietários de pequenas oficinas de marcenaria . tipögrafos, ourives, pintores, encanadores, etc. 0 bairro , pela sua origem simples de população marcadamente trabalhadora, abrigava as mais bizarras atividades que merecem destaques neste estudo, nāo pela expressividade numérica, mas como indicadoras de um quadro cultural e econômico, onde o trabalho para a sobrevivência podia ser encontrado com rela tiva facilidade em função das estreitas relaçōes de vizinhança. Segundo depoimento obtido durante as entrevistas , identificamos pessoas que viviam como biscateiros, prestando serviços de consertos que, ao mesmo tempo ganhavam a vida matando porcos e cabritos para aquelas pessoas que costú mavam criā-los nos fundos dos quintais. A presença de pessoas que cultivavam este hábito era muito grande : o fato está muito ligado ao hābito italiano de incluir o cabrito como importante elemento na tradiçāo alimentar."Mas tanto" era um destes italianos que, em troca de favores ou de pagamento, realizava o trabalho para a população do peda 
ço, próximo à rua Santo Antonio. Forte é ainda a lembrança dos antigos moradores daquele "velho pastor do asfalto". Um homem que nas tranquilas manhās do bairro, ainda nāo rouba da pelos automóveis, passava com suas cabras amarradas unas às outras, tocando aquelas sinetas penduradas nos ani mais, vendendo o leite ordenhado na frente do freguês, que acreditava fazer bem para a saúde.

O crescimento dos bairros de São Paulo se fez de forma muito contrastante, seguindo a lógica do modo de produção capitalista, ou seja, revelando a desigualdade muito grande na distribuição da renda. Esta urbanizaçāo esteve alicerçada na natureza como se definiu este modo de produção na evolução histórica do Brasil, especial mente no caso de Sảo Paulo. Muito jả foi dito sobre a cida de como resultado da produçāo social do trabalho. A maneira como se estruturou a divisão social do trabalho deve ser encarado, portanto, como ponto de partida desta produção e. Eunsequentemente, da natureza do espaço da cidade . Para tanto, gostariamos de invocar aqui, a seguinte anålise de Francisco de Oliveira:

"Nas cidades, a diferenciaçāo da divisāo so cial do trabalho tem outras características, outras matizes, e outra formaçāo. A Passagem para o trabalho livre funda, também, a possibilidade de un modo de produçāo de mer cadorias: a separaçāo entre produtores e meios de produção vai fazer crescer enormemente uma população para o capital, com o que a potencialidade do capital é reforçada. Entretanto, a conversāo dessapotencialidade en real é barrada por uma série de fatores. Em primeiro lugar, a ausência de capitaliza cão anterior na forma de mảquinas e equipamentos força agora una capitalização de ni- 
da não tem, pratjcamente, nenhuma virtude técnica a transferje para o capital. Sua anterior condição de escravo the embotara a capacidade técnica... Não é estranho, por isso, que, em meio a uma abundancia de força de trabalho, a indústria brasileira nos fins do século XIX e primeiras décadas do século $X X$ tenha que socorrer-se do imigrante estrangeiro, cuja predominância no total da classe operária ainda era absoluta em 1920". (01iveira, p. 25).

Fica implícita na tese do autor do texto acima transcrito, que os limites da expansão do capitalismo brasileiro não eram somente uma questão de natureza econômica, mas também cultural. Não nos interessa aqui discutir - papel determinante do fator econômico no processo da pro duçāo social, tese que nós endossamos, o que nos interessa é ver como as bases econômicas da sociedade se viram "cons trangidas" por aqueles fatores culturais e como os mesmos foram sendo superados, principalmente no processo de produ ção do espaço urbano.

A implantação do trabalho livre e assalaria do e sua consolidação como a forma determinante na economia urbana industrial, pressupunha o surgimento de novas necessidades de equipamentos urbanos, desde transporte, energia, serviços em geral; até aquela que é a mais evidente das necessidades de qualquer ser social - a habitação. 0 capitalismo libertou o homem da senzala, porém, aprisionou - a uma eterna luta pela habitação, problema insolúvel no capitalismo. A moradia, uma "mercadoria" sui generis, acabou estimulando a expansão de um grande mercado imobiliā rio neste processo de consolidação do capitalismo no Brasil. Este mercado permitiu o enriquecimento de muitos seg- 
mentos socials, fossem edes originárjos das odigarquias do minantes ou não. A introdução das novas relaçōes capjalis tas fundamentadas no trabajho livre c assalariado e na nova economia urbana industrial, permitiu o surgimento de uma classe de "novos ricos" nascidos da exploração da "ren da urbana". Para Paul Singer, o acesso ao uso do solo urba no pode ser conseguido mediante o pagamento de um aluguel ou, então, pela compra de um direito de propriedade, fatores que estimularam a expansão daquele mercado. Para o tra balhor assalariado o acesso à casa própria sempre se apresentou como um grande obstáculo, submetendo-o à extorsão dos aluguéis. Assim, a emergência desta classe trabalhadora significou para a nossa economia o surgimento de um ámplo e promissor "mercado imobiliārio". Atrás da realização do "sonho da casa própria", nascido no "pesade10" do capita lismo, este trabalhador alimentou formas "selvagens de acu mulação de capitais" realizadas pelas "novas companhias imobiliárias".

A demanda por habitaçōes, nascidas do surto da industrializaçāo em São Paulo -acabou sendo resolvida de diferentes maneiras. Nas primeiras décadas do século os próprios empresários passaram a construir as "vilas operárias", respondendo a uma demanda que eles mesmos haviam criado. Ao construirem estas vilas resolviam o problema da habitaçāo para sua força de trabalho que precisava ser "qualificada" e esta, era muito difícil; para tanto, tinham que fixä-la junto à fábrica. Ao mesmo tempo que resol viam aquele problema, criavami mecanismo de dominação sobre os trabalhadores, tornando-os cativos das empresas. Estas vilas proliferaram nos bairros que se definiram como industriais: Brás, Móoca, Ipiranga etc. A outra, foi atra- 
vés da própria jniciativa do trababhador, pela aquisjção de um terreno sobrc o qual construja sua moradja. Além da iniciativa privada dos empresárjos industriais que construiam as vilas opcrárias com objetivos estratégicos de controle sobre a força de trabalho e ganhos tínhamos também, aqueles quc passaram a investir. seus capitais exclusivamente ou nāo na exploração imobiliária, construindo e vendendo ou alugan do casas. Instituiçōes públicas, como caixas econômicas e institutos de pensōes e aposentadorias, entraram numa fase posterior, quando $j a ̄$ se havia consolidado um proletariado urbano mais significativo, isto após a década de 1930. Quan to maior a industrialização, maior o crescimento populacional nas cidades e o problema da moradia se agrava va. Neste quadro o imigrante desempenhou papel importante, nāo somente para preencher aquele "vazio" deixado pela escravidão, conforme assinalou Francisco de 0liveira, mas tam bém, nas transformaçōes sōcio-culturais, principalmente em Sāo Paulo. A entrada do imigrante, principalmente dos italianos em São Paulo, deixou marcas profundas na cidade. Sua entrada não significou somente uma solução para o problema da mão-de-obra, ele contribuiu para que, aqui, se consolidasse rapidamente a ideologia capitalista. Estes italianos, marcaram com sua presença um novo perfil para muitos bairros paulistanos, entre eles, "Brás, Bexiga e Barra Funda".

A presença italiana em São Paulo não deve ser buscada somente na forma macarnônica de falar dos ita lianos e oriundi ou em alguns nomes de empresários "bem sucedidos", mas no que ficou de sua contribuição cultural,den tre elas na evolução arquitetônica e urbanistica da cidade. Estiveram profundamente associados à novas propostas para resolver o problema da moradia, fossem como "capomastri" ou 
como proprietúrios naquele mercado imobiliário. Se a presen Ça italiana pode ser, ajnda, encontrada no conjunto do património artistico ou nos palacetes dos lugares aristocrátí cos da cidade, scrá sobretudo naqueles bairros paulistanos acima citados, que encontraremos de forma mais marcante 0 seu papel histórico nas transformaçōes de São paulo. Os cor tiços do Brás e do Bexiga que proliferaram nas primeiras dé cadas deste século, representaram uma saida para o problema da moradia e significaram o surgimento de uma nova concep ção de vida. Os italianos nāo foram originalmente seus cria dores, mas deixaram uma marca sui generis nesta forma de morar. Moradores e "produtores" de cortiços, tornaram-se personagens vivas da cidade que se urbanizava. Estes bairros, enquanto produção coletiva de uma cultura dão maior legitimidade histórica à contribuição dos italianos para as transformaçōes econômicas e culturais de São Paulo.

0 bairro do Bexiga foi, nesta primeira metade do século $X X$, profundamente marcado pela ideologia da italianita:

"Os imigrados são, pois, instrumentos da politica italiana; em alguns momentos eles estarāo sem o saber, a serviço do expansionismo dessa politica... Como constata Sérgio Ro mano: os italianos expelidos "criam uma Itália fora da Itália". Tal contexto explica a confusāo daqueles que são forçados a se expatriar. Estes "homens sem paz", como Constantino Ianni os denomina, estão marcados pa ra sempre". (Carelli, p. 24).

Estas marcas, poderiam ser vistas no cotidia no destes italianos do Bexiga. Na chiacchena de familia. quando as mesmas juntamente com os amigos, se reuniam ao ré dor dos fogōes à lenha ou à carvão, nas noites frias, para 
comerem castanhas assadas. A inexisténcia da television fazja com que estas familias se reunissem para contar histó rias. sempre carregadas de forte saudosismo da pátria distante. Não era raro, nestas reuniōes, participarcm também os vizinhos mais próximos, ou mesmo, alguns italianos que morassem mais distantes. Os filhos e netos, querendo ou não, acabavam participantdo daquela atmosfera de familia, onde se mesclavam laços de parentesco e vizinhança. Estes laços acabavam definindo a natureza dos grupos de rua da rapa ziada, separados por sexo e idade, definindo pactos de lea 1 dade como continuidade dos laços de familia. Dentro de uma atmosfera assim, a rua passava a ser aquele lugar de convivio, como prolongamento da casa.

O Bexiga evoluiu dentro de São Paulo como um bairro de características bem definidas. Relaçōes de vizinhanças muito estreitas, marcadas por uma forte identidade étnica-nacional de italianidade. Um lugar onde as profissōes artesanais imprimiram sensiveis marcas no seu perfil cultural. A possibilidade de associar residência e oficina, permitia a este tipo de trabalhador dispor do seu tempo da maneira que melhor the provesse. Desta forma, este habitante podia dividir seu dia em horários bem marcados: a hora do trabalho na oficina; da sesta, novamente do trabalho e finalmente, no término da jornada, o convívio $\operatorname{com}$ a familia. Nestas oficinas trabalhavam, geralmente, qua se todos os membros da familia. Assim, regulados pelo mesmo horário de trabalho, podiam compartilhar conjuntamente de todas as atividades, desde as refeiçōes ao lazer. A autọ ridade do chefe de familia residia basicamente no fato de ser ele o único proprietário dos "meios de produçāo" e quem estabelecia o ritmo de trabalho. Esta unidade de produção, 
Gundamentada na exploraçõo do trabalho famijiat ern dominan te crtre a população ativa do bajrro. Ira também comum encontrar-se jovens aprendizes, filhos de outras familias, in seridos dentro destas oficinas para aprender o oficio, rece bendo pequenos salários. Na maioria das vezes, os membros familiares trabalhavam sem remuneração salarial. Os exceden tes acumulados eram administrados pelo chefe da familia.Foi desta forma que muitos italianos do bairro conseguiram enriquecer-se, caracterizando-se, assim, uma forma de "acumulação primitiva do capital". A vontade de "crescer na vida" permeava aquele dia-a-dia, passando-se esta aspiração de pai para filho.

Nas primeiras décadas deste século, quando São Paulo vivia a "nova experiência urbana industrial", as possibilidades de sucesso para estes pequenos empreendedo res era grande:

"Para Edegard Carone, o início da ascensāo de Siciliano apresenta caracteristicas comuns às de milhares de outras fortunas. Isto se deve à existência de um mercado interno dinâmico, ligado ao desenvolvimento da cultú ra do café, à acumulaçāo de fundos duramente adquiridos, aos lucros do comércio e à força do carāter... Esse homem colocou-se à testa de uma fortuna considerāvel e viu seus filhos casados com a elite do país. No entan to forte ligação a pátria e cultivou sempre - espírito de italianidade. (Carelli, p. 45)

Se o exemplo de Alessandro Siciliano (18601923). conforme Edgard Carone apontou-nos para caracterizar - papel dos italianos nesta industrialização; aqueles italianos "bem sucedidos", temos outros que demonstram que nem todo italiano com força de carāter e trabalho árduo conse - 
guill prosperat. Jose de Souza Mations demonstrou-nos em sua pesquisa: Conde Matarazzo, o empresárjo c empresa,que a imagem que se formou deste ltaliano bem sucedido, cuja rí queza adveio da "virtude do seu trabalho", é falsa. Pela análise, Francesco Matarazzo já era um homem de posses quando se iniciou como empresário. Sabemos que a maioria daqueles artesãos do Bexiga mal chegaram a transformar-se em empresários de "fundo de quintal". Apesar de terem sido "virtuosos" trabalhadores, não conseguiram fazer grandes fortunas. Para estes, não foi somente a falta de uma poupança inicial que impediu o maior sucesso ou mesmo o fracasso como empresārios. A ideologia empresarial também diferenciou estes empresários. 0 primeiro tipificou uma forma de empresariamento que incorporou "os riscos de uma economia de merca do": entrar num jogo onde ninguém entra para perder. A natu reza ainda liberal para a maioria da economia urbana industrial, criava um mercado altamente concorrencial, principal mente para a indústria de bens de primeira necessidade. 0 lucro almejado tinha que ser calculado racionalmente, tinham que se eliminar todos os possíveis riscos que comprometes sem os investimentos iniciais e futuro do empreendimento.A perspectiva de se criar uma economia de escala dominava o espirito destes empresārios. Os segundos, limitavam-se a trabalhar dentro de estreitos mercados, representados por uma clientela cativa, para a qual trabalhavam por encomenda.

Transpondo-se 0 instrumental conceitual trabalhado pelo professor Milton Santos, quanto ao conceito de modernização tecnológica e os dois circuitos da economia ur bana para a nossa análise teríamos a seguinte situaçāo: No circuito superior, aquele que usa uma tecnologia "capitalintensivo", operando com créditos bancários, grandes volu- 
mes de mercadorlas, onde os presos sltunm-se dentro de cer tos limites, trabalhando com a publicidade em muitas vezes com o apoio governamental: "Apesar do cantrole de preços excrcido nas atividades do circuito superior e dos elevados lucros em relação ao volume total de produção, o rendimento por unidade é baixo". (Santos, p. 42). Neste ca pitulo poderemos enquadrar empresas como de Alessandro Siciliano ou Francesco Matarazzo, enquanto que, no circuito inferior, inversamente àquele enquadraremos as pequenas unidades de produção de tipo artesanal. O Bexiga foi basica mente ocupado por estas últimas, e dificilmente se inseriram no circuito superior da economia urbana de São Paulo. Longe de caracterizar uma relaçāo dualista de sociedade,es tes dois circuitos colocaram-se numa interdependência dialética. Era comum encontrarmos pequenas oficinas de serra1heria, costura, ourivesaria., sapataria etc. trabalhando sob empreitadas feitas por grandes empresas. Além do mais, estas pequenas oficinas acabaram funcionando como "centro de qualificaçāo de mão-de-obra" para a industrialização de São Paulo. A exploração do sentimento de italianità dentro daquelas relaçōes econômicas eram muito frequentes, como nos apresenta em seu trabalho, Mario Carelli:

"O ideal de italianitá é alimentado com segundas intençōes interessadas pelo governo, por financiadores italianos $e$ por industriais italianos de São Paulo. E significativo que os fascistas contem com esses sentimentos patrióticos para difundir seu movimento. ao passo que os anarco-sindicalistas e os socialistas nāo param de denunciä-10... As profundas diferenças sociais que existem na colônia italiana explicam por que as posi çōes de classe se sobrepujam à identidade 
nacional. Assim. Francesco Matarazzo fracassa quando tenta recorrer à soljdarjedade reqjo nal para parar a greve de 1907 na fábrica Mariangela, enviando um contramestre de Barj pa ra convencer seus patriotas a retomar o trabá 1ho". (Care11i, p. 25)

Podemos deduzir, ao contrário do que muitos afirmam, que os italianos de São Paulo, longe estavam de formar uma "grande familia".

A presença de uma estrutura sōcio-econômica de pequenos negociantes e proprietários imobiliários, e de significativa camada de "aprendizes" e assalariados, mesclan do entre estes últimos, italianos e negros, definia um pater nalismo do tipo "pequeno burguês" no comportamento da maio ria da população do bairro. Apesar das estreitas relaçōes de vizinhanças, procuravam manter claro os limites na "intimida de familiar". Vivendo-se relaçōes onde as troças de favores, compadrismo e espírito de italianità eram marcadas por uma grande carga de emotividade, aqueles limites eram facilmente transpostos, criando-se, assim, grandes conflitos familiares. Os cortiços foram formas de habitaçōes onde melhor se caracterizou este tipo de convivência e psicologia social. Nelas, a estrutura familiar ficava profundamente evidenciada. Raramente se aceitavam inquilinos que não fossem casados ou entāo casais que não tivessem relaçōes "legitimadas". A condição de proprietário e morador, fazia com que o dono usurpasse a condiçāo de "policial e mantenedor da boa moral e inte gridade física do cortiço", contando com a "cumplicidade" da maioria dos moradores. Sua presença e a preservação de sua individualidade familiar, expressa na própria maneira como sua habitaçāo se colocava no conjunto do cortiço, sempre isó 
lada do conjunto, dava-1he um ar de soberania e parcimônia no tratamento com seus inquilinos.

O Bexiga foi um bairro de pequenos negociantes, trabalhadores "autônomos" ou assalariados. Este fato marcou a simplicidade da maior parte da sua paisagem. Em suas referências sobre a evolução urbana de São Paulo, assim, escreveu Ernani Silva Bruno:

"...em pesquisa feitapelo professor Donald Pierson em 1942, através de dados colhidos no Bexiga, na Móoca e no Canindé, apra repre sentar o "nivel inferior" de moradia, e no Jardim América, Pacaembu e Higienópolis para representar o "nível superior"... Jã na ärea de terreno utilizado por edificação, obser vou Pierson que no Canindé a média foi de 114 metros quadrados, no Bexiga de 202 e na Móoca de 162 , ao passo que no Pacaembu foi de 883, no Higienópolis de 1531 e no Jardim América 1580". (Silva Bruno, p. 1324)

Não nos foi possivel obter o percentual de área edificada por lote. Sabemos que a média do tamanho dos lotes, já nos permite uma aproximaçāo da realidade territorial dos bairros, porém, a densidade de ocupação dos lotes, é que nos permitiria identificar melhor a natureza do uso do solo. Na impossibilidade de acesso a estatísticas precisas, apoiamo-nos em dados obtidos através de depoimentos históricos sobre a evolução das habitaçōes do bairro do Bexiga.

No início da ocupaçāo do bairro, as casas nāo ocupavam todo o lote. A medida que a demanda de moradia crescia com a industrialização da cidade, os proprietários passaram a sumentar a parte edificada construindo cômodos . seguindo a orientação alongada daqueles lotes. Além de in- 
corporat novas áreas construijas, transformavam, também, aqueles porōes altos. em novas habjtaçoes. Vormalmente estes cômodos eram formados por quarto, sala cozinha. As instalaçōes sanitárias e os tanques de lavar roupa eram coleti vos. Desta forma, os terrenos que representavam um valor de uso para seus proprietários, passaram a representar uma forma de obtenção de renda. A possibilidade de se viver da cobrança de aluguéis, fascinava os detentores daqueles 10tes que se apresentavam até então com grandes áreas "ocio sas" - "um valor que se valoriza" no interior da produção social da cidade. Assim, foram surgindo os cortiços. Juntamente com a finalidade de se transformar estes "novos espaços" em fator de renda, também se expandiam as construçōes para abrigar os filhos dos proprietários. Era comum, entre os italianos, acomodarem-se os filhos nos mesmos lotes,quan do estes se casavam.

A clientela que afluía pará os cortiços do Bexiga era desde italianos, recém-chegados, ou negros. Estes últimos, junto com os italianos, formavam a maioria absoluta da população do Bexiga. Eram raros os cortiços onde negros e italianos partilhavam do mesmo espaço. A preferência dos proprietários tendia a alugar os cômodos aos compatriotas ou aos oriundi. Os negros acabavam formando seus próprios cortiços ao lado dos italianos:

"Em 1910, o viajante italiano Alfredo Cusano fica chocado pelas condiçōes de vida dessa gente. Nessas ruas estreitas e tortuosas encontram-se guetos de italianos extremamente pobres. Na entrada do bairro, o largo do Piques se transforma em lagoa, depois em lamaçal. cada vez que chove. 0 desconforto $e$ a insalubridade sāo reforçados pela elevada densidade da população. E um dos bairros de 
São Puulo com maior concentração de habitacöes cojetivas, onde os italjanos se encon tram ao lado dos miscráveis cortiços dos negros, antigos cscravos marginalizados na sociedade paulista". (Cared1i. p. 36).

Os italianos pobres, somente em caso de necessidade aceitavam morar nos cortiços junto aos negros. Apesar de manterem relaçōes amistosas, italianos e negros muito raramente definiram relaçōes de casamentos. As relações eram muito mais de "senhor e servo", permeada pelo paternalismo mais do que verdadeiramente pela integração étnica e social. Assim, a condição material do cortiço estava nu彑 ma relação direta com a condição de renda dos seus moradores. Os negros, historicamente representavam os trabalhadores recém saídos da escravidāo. Eram a força de trabalho mais abun dante e menos qualificada, vivendo na maior parte como subempregados. Desta forma, italianos de baixa renda tinham que compartilhar com os negros os tipos de cortiços de maior pré cariedade no bairro.

Alèm de estarem estratificados pelas condições físicas, os cortiços estavam de uma certa forma zonea dos. Os cortiços de italianos e oriundi na sua maior parte ficavam nas āreas da velha ocupaçāo italiana como os da rua 13 de Maio, Rui Barbosa, São Domingos, Conselheiro Ramalho . Santo Antonio, Abolição, Fortaleza, Manuel Dutra, etc. Os negros concentravam-se mais na parte baixa da regiāo da Grota: "Nas casas de cômodos da Almirante Marques Leāo, nas décadas passadas, viviam italianos e seus descendentes, seguidos de mulatos, negros e espanhóis..." (Lucena, p. 56). Segundo relatos encontrados na obra de Ernani Silva Bruno, a regiāo da Grota, desde o periodo escravagista jā era procu- 
rado pelos negros fugitivos, onde chegavam a formar "quilombos". Lista tradjcão de lugar de negros marcou a rua Al. MaI ques l.eão, chegando mesmo a ser discriminada por mujtos dos moradores italianos arrivistas. As referencias feitas pelos narradores sobre as condições físicas dos cortiços do Béxiga nem sempre são muito verdadeiras.

Encontravam-se com frequência estas habitaçōes coletivas em precárias condiçōes de higiene e de aparên cia, porém, isto não era a regra. Como a maioria destes cortiços era também lugar de moradia dos proprietários e seus familiares, procuravam estes preservar suas condiçōes materiais, mesmo porque eles representavam um "capital" investido do qual obtinham suas "rendas". Mais do que fazer do aluguel uma forma complementar de renda, esta forma de exploraçāo imobiliāria passou a ser uma ideologia de vida:

"...ali, onde ainda havia uma parcela livre, construia-se uma casa, onde havia uma saida supeerflua muravam-na; o valor da renda cresceu com o desenvolvimento industrial e quanto mais ela se elevava, mais freneticamente se construia, sem a mais pequena preocupação com higiene e o conforte dos habitantes, sendo única preocupação a de obter lucro possível e de acordo com o princípio: por pior que seja um casebre, hã sempre um pobre que não pode pagar um melhor". (Engels, p. 89).

A tendência natural de evolução desta habitaçōes coletivas, seja pela grande população que abrigam, seja pela maneira como na maioria das vezes sāo elas improvisadas com materiais precários, ou seja ainda pela avareza dos seus proprietários é de se tornarem lugares de baixa qualidade de $v$ ida. No caso do Bexiga esta regra esteve sempre modificada em funçāo de fatores de ordem culturad. A precariedade das 
instalaçoos era compensada pelo zelo dos moradores na limpe za dos quintajs comuns c sanitários, pejas pinturas que regujarmente faziam na parte intcrna cexterna dos cômodos, pe los cuidados dispensados a pequenos "jardins"improvisados em lugares onde a terra ficava exposta. Quanto mais estrejtos eram os laços de vizinhanças maiores eram os cuidados dis pensados à preservação destes cortiços. Neles, muitos dos inquilinos viveram longos anos, criando seus filhos até casarem, saindo somente quando conseguiam comprar a casa própria, alugarem outra em bairros mais distantes ou quando morriam. Portanto, o tempo de permanência dos mesmos no imó vel alugado era quase sempre muito longo. As relações de proximidade com os proprietários que moravam na parte "nobre" do imóvel, ou seja, na parte que dava frente para a rua, fazia com que estes exercessem uma relativa vigilância sobre os mesmos.

Como escreveu Engels, estas habitações coletivas representam formas de exploração sobre as camadas mais pobres da população; porém, a pobreza da maioria daque les italianos que moravam em cortiços, não impedia que tornassem estes ültimos em "lugares civilizados". Para o italiano, imbuído de un sentido de posse e propriedade muito mais forte do que no negro, sentimento fortalecido pela con

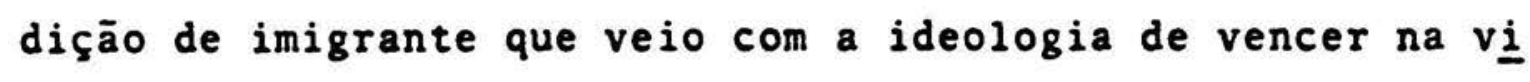
da, a casa sempre foi um símbolo de ascensão social, portan to. ter a casa própria ou tratā-la com zelo e decoro estavam incorporados àquela ideologia. Estes fatores de ordem cultural nāo explicam a formação dos cortiços, mas as diferenciaçōes entre os mesmos.

As generalizaçōes feitas sobre as condiçōes 
habjtacjonajs dos imigrantes, dão-nos a idéiu de posiçōes litistas dos narradores demonstrando muitas vezes equívocos, onde a "deselegância" da aparência passa ser sinônimo de miséria:

"io Brās, a sucessão monótona de pequenas hạ bitações com um só pavimento, sem jardim na frente e em geral geminadas só é entrecortada por fachadas de fábricas ou de galpōes.To das estas casas miseráveis, sem nenhuma característica particular de estilo, são construidas segundo o mesmo modelo. Elas têm cin co metros de largura por vinte e cinco de profundidade. A fachada compreende uma janela e uma porta, que se abre para um corredor de acesso aos quartos. Ao fundo se acha a co zinha, depois um pequeno pátio com um tanque, um varal de roupa e um local para fazer a hi giene e. as necessidades". (Carel1i, p. 35).

Pela descrição feita sobre este tipo de habí tação popular, a qualificação de "casas miseráveis", parece nos equivocada. Entre pobreza e penúria extrema, que nāo nos parece ser o caso descrito, existe muita diferença, aquela que nasce do preconceito nem sempre transparente no discurso.

O Bexiga guardou até a década de cinquenta a maior parte dos elementos urbanísticos descritos até aqui e que the davam identidade como bairro. Mesmo com as obras de implantaçāo do projeto de Prestes Maia, em 1940 do "Perí metro de Irradiaçāo", quando foi construída a atual rua Maria Paula e o viaduto Jacareí, sobre o ribeirão Bexiga, a vida do bairro não chegou a ser profundamente alterada. 0 corte acabou sendo mais na paisagem, pois o Piques continua va sendo incorporado pela população como sendo Bexiga. Com 
zação. Cra um lugar do bajrro onde o adensumento pela vertá calizaço dava-lhe uma natureza singular no conjunto do Bexiga.

A verticalização vertiginosa de São Palllo,ca da vez mais invadia os espaços vazios do centro $e$ seus limites. As grandes avenidas representadas pelos enormes eixos e anéis rodoviários favoreciam esta verticaliza ção. A valorização dos terrenos pelo adensamento vertical , estimulava o "apetite" daqueles que especulavam com imóveis. Era comum no Bexiga alguns proprietários verem com "bons olhos" a ocupação daqueles terrenos vagos, alheios ao que significava aquele "novo estilo de morar" para o bairro,como uma forma de valorização do seu imóvel. Praticamente, até a década de trinta, os grandes edifícios de apartamentos es tavam circunscritos ao centro da cidade. Os edifícios que passaram a ser construídos na Av. Nove de 9 de Julho a partir da década de quarenta seguiram os padrōes daquele centro. A medida que as construçōes avançaram ao longo desta avenida, novos estilos foram surgindo, cada um marcando um momento da ocupação deste "novo Bexiga". Assim, como a Nove de Julho, a av. Brigadeiro Luiz Antonio e a rua Maria Paula, presenciavam as primeiras construçōes de grandes edifícios. Para o sul, no Morro dos Ingleses e alto da Grota continuavam os grandes casarōes.

A partir da década de cinquenta as coisas co meçaram a mudar no bairro. A "grande muralha" de edificios começara a cercar aquele espaço de casas baixas seguindo as avenidas limítrofes. Segundo a obra de Jurgen Richard Langenbuch, Estruturaçāo da Grande Sāo Paulo, a grande caracte ristica que o processo de crescimento da cidade apresentava 
ra: compactaçio da irca centras, expansão da área cojificada ubre porçóes dos arredores que não tinham conhecido um de envolvimento suburbano expressivo e expansão da área edifiada sobre porçōes dos arredores significativamente suburbaizados, compreendendo a absorção territorial de numerosos úcleos suburbanos. Dentro deste processo encontramos o Bexi a, que de longa data já vinha revelando esta tendência a um densamento populacional. Entre 1920 e 1940 o bairro dobrou ua populaçāo. De 44.688 habitantes passou para 81.431; 0 nico bairro colocado dentro dos limites internos da cidade semelhança do Bexiga, que sofreu o mesmo crescimento foi Cambuci. Após a década de cinquenta sua taxa de crescimen- passou a decrescer em relação à nova periferia.

Analisando-se a participaçāo do Bela Vista no rescimento geométrico da populaçāo para o período entre 950-1960, numa ordem de variação que ia desde o crescimento egativo até uma escala de 16,08, o bairro da Bela Vista co ocava-se na faixa daqueles que cresciam entre 2,18 a 4,08 . uando comparados estes dados com a densidade demográfica eistente no bairro, na mesma época, verificamos que a taxa e crescimento populacional colocava-se inversamente proporional à densidade numa escala de variação para os domicíios por ha., numa ordem de variação de 5 em 5 domicílios. Bela Vista ficava no último lugar com 30 domicílios por a. Sobre estes dados tirados do seu livro, Jorge Wilheim,a $\underline{s}$ im se colocou: "No crescimento geométrico da populaçāo, enre 1950 e 1960, percebe-se que as menores taxas de cresci lento foram registradas em subdistritos com maior densidale." (Wilheim, p. 65). Constatamos, assim, que mesmo sem , liderança nas taxas de crescimento, continuou o bairro lilerando o nivel de concentraçāo de domicílios por ha. Apesaŕ 
de não continuar crescendo como no periodo anterior observen do, o adensamento do Bexiga continuou aumentando pela incor poração dos seus vazios localizados ao longo da avenida Nove de Julho e alto da Grota, neste último, além das casas. por apartamentos de luxo. Na Nova de Julho mais por apartamentos, raramente por casas. Este periodo marcou o início do processo de profundas transformaçōes ocorridas na paisagem e na estrutura social do bairro.

\section{2. "Bexiga - Ano Zero"}

A industrialização que se verificou no Brasil no período posterior à Segunda Guerra Mundial e sua con centração em São Paulo, determinou um novo impulso transfor mador para a cidade. Além de um grande centro industrial, tornou-se também um grande centro de serviços. Estes dois fatores condicionaram a natureza do seu espaço urbano. Defí niu-se um intenso processo de horizontalização e verticalizaçāo, este ültimo, principalmente na área central e limi tes, formando assim, um "núcleo de urbanizaçāo compacta e continua". Mais do que uma massa de concreto, esta nova natureza de espaço definiu uma nova forma de vivê-10: "Diante destas necessidades sempre maiores, o espaço é sempre menor e os intervalos, indispensáveis para evitar a expansão indi ferenciada de um mar de cimento, sāo sempre menos possíveis. Exatamente aqui se revela a última e mais pesada contradi çāo da cidade". (Giuducci, p. 89). A nova natureza do capitalismo brasiliero, alicerçado cada vez mais em bases monopolistas fez surgir as grandes corporaçōes empresariais mul tinacionais, dando feiçōes novas a esta urbanizaçẳo. Defi - 
nindo um rjtmo acejerado de crescimento para a cidade fez com que rapidamente os Jugares se degenerassem materialmente nos scus equipamentos, redefinindo um processo ininterrupto de novas hierarquias de lugares de serviços, residencias e indústrias dentro deste tecido urbano. O capitalismo monopolista criava condiçōes para o aparecimento das grandes com panhias da inústria da construção civil.

Este novo capitalismo acabou manifestando-se no perfil da urbanização pela maneira como as grandes unidades de produção e comercializaçāo geraram seus estabelecí mentos. Grandes obras de arquitetura e paisagismo abrigando instalaçōes industriais em edifícios de arrojados desenhos arquitetônicos, assim como os grandiosos "Shopping-Centers". instalados em enormes áreas urbanas ao longo de vias expressas ou próximas a elas. 0 Estado teve que assumir a responsa bilidade de importantes obras de equipamento viärio para ace lerar o escoamento dos transportes: caminhōes, enormes carre tas, ônibus $e$ o ingresso contínuo de milhares de automōveis novos no trânsito da cidade, lançados no mercado pelas grandes montadoras agora implantadas dentro da região metropoli tana de São Paulo. 0 automóvel como o novo "grande persona gem" urbano redefiniu os espaços da cidade:

"0 automóvel redimensionou não somente o espa ço social. Tornou-se cada vez mais um fator de status e ao mesmo tempo um dos grandes ini migos do homem urbano... 0 ingresso continuo de veículos, força o espaço físico, levando à necessidade de aberturas de grandes vias expressas e alargamento de outras, destruindo neste processo aspectos pitorescos da cidade e com eles sua própria memōria" (Scarlato, p. 97). 
A csta onda de crescimento e "progresso". PE la sua rapjdez c mancira, tivemos como resposta o surgimen to de uma cidade "amnésica", uma "Nova Babel". Quanto mais a cidade cresceu, mais se acentuou a segregação através das diferentes formas de uso do solo. O estado passou a interfe rir de modo acentuado neste crescimento. A lei Geral de zoneamento do Município de Sāo Paulo, veio institucionalizar as discriminaçōes nas formas de uso do solo urbano:

"Assegurar a reserva dos espaços necessários em localizaçōes adequadas destinadas ao desenvolvimento das diferentes atividades urbanas (sic); assegurar a concentração equili brada de atividades e pessoas no território do município mediante controle do uso e do aproveitamento do solo (sic)". (CET, p. 12)

Desta forma, o poder público coloca-se como uma das forças no processo de produção e preservação dos espaços de tal forma que ficasse garantido os direi tos até então adquiridos, o que, obviamente, significou pre servar os direitos da classe dominante, tanto no que se. referia à salubridade dos seus bairros, jardins, condominios fechados, como a boa localização dos seus distritos indus triais. Aqueles que jā se encontravam deteriorados, conti nuaram como estavam. Ao mesmo tempo significou, também, uma forma de intervençāo nos mecanismos do mercado imobiliārio.

As metrópoles transformaram-se nos monumen tos do mundo capitalista - sua apoteose - centro das gran des decisōes financeiras, de produção tecnológica, consumo e mercado de força de trabalho de toda qualificação. Aquela nova forma de viver, jä mencionada, torna-se uma imposição de vida e nãe uma opcāo. Elas definem as novas condiçōes so ciais de reproduçāo da força dè trabalho, criando necessidą 
des novas c "traumáticas" para classe trabalhadora em geral, criando formas mais sutis de alienação. Para aquelas pessoas que nasceram durante o processo mais acelerado da mudança não sc formou a "consciência de perda", tempo e espaço para elas estiveram em "perfeita sincronia". Para as velhas, esta relação tornou-se diferente. As mudanças no espa ço passaram a ser muito räpidas, enquanto a nova paisagem surgia a antiga ainda estava gravada na retina, tentando re ter na lembrança a imagem de um espaço que o progresso devo rava sem mastigar. Assim, gostaríamos de invocar o seguinte pensamento da Bachelard:

"A topoanālise seria então o estudo psicológico sistemático dos lugares físicos de nossa vida intima. No teatro do passado que é a nossa memória, o cenário mantém os persona gens em seu papel dominante. As vezes acredí tamos conhecer-nos no tempo, ao passo que se conhece apenas uma série de fixações nos espaços da estabilidade do ser, de um ser que não quer passar no tempo, que no próprio pas sado, quando vai em busca do tempo perdido. quer "suspender" o vôo do tempo". (Bachelard, p. 202).

A topoanālise permite-nos perceber o nivel de subjetividade na relação tempo e espaço vivido pelo homem nos momentos dos "saltos qualitativos" do processo histórico; a maneira como se produz o imaginário naquela relação - no seio do "vôo'suspenso" - criando muitas vezes um mundo de devaneios de representaçōes férteis para prolifera rem as ideologias.

Porém, este tipo de abordagem torna-se insuficiente para explicar o comportamento social urbano nascido com aquele surto de industrializaçāo acelerada, acompa - 
nhada do processo de metropolização. tila vem com a marca de uma individualizaçāo mujto acentuada, contra a quas, Henri Lefébvre, assim se coloca: "Quanto à reflexão dita "existen cial", esta se baseia na consciência individual, no individuo e nas provaçōes da subjetividade antes do que numa realidade prática, histórica e social". (Lefebvre, p. 36). Enquanto Bachelard abre-nos a perspectiva para a compreensão dos mecanismos psicológicos entre espaço e ideologia, Lefebvre nos remete à sua superação na busca daquela transpa rência histórica. Não nos parece que as mesmas sejam excludentes, mas complementares. A proposta de Lefebvre permitenos perceber a globalidade do processo histórico, dando-nos a dimensão concreta do ser social, mostrando-nos as bases de onde são produzidas as ideologias. Quando afirmamos que as ideologias não têm histōria baseamo-nos no fato das mesmas serem representaçōes "distorcidas" do real. As formas como os homens produzem suas condiçōes materiais de existência é que têm história, pois ëstas é que estão na es sência do movimento do processo histórico. No processo de desenvolvimento da vida social estas representaçōes acabam adquirindo autonomia. Assim se produzem as ideologias. que deixam de ser simples representaçōes para se transformarem em instituiçōes com "vida própria" legitimada pela sociedade, que acaba perdendo a dimensão do que é essência e aparência do real. 0 que dá movimento àquelas representaçōes é - movimento do ser real da qual ela é manifestação. Assim a contece com as ideologias no movimento histórico; movimen tam-se como consequência do movimento do ser que tem a essência do movimento, ou seja, o homem produtor de sua existência. A medida que Bachlard nos permita perceber o nível de subjetividade destas representaçōes, estará contribuindo 
para comprecndermos como são produzidas os "arquétipos" dos lugares onde os individuos vivem e consequentemente as jdeo logias do espaço.

Não é fácil trabalharmos com este nível de a nálise - tentar compreender o impacto que a urbanização traz para a sociedade. Mesmo sendo difícil não devemos excluir esta possibilidade, principalmente quando estamos tra balhando não somente com a "geometria do espaço" mas com suas representaçōes afetivas. Aqueles "arquétipos" sobre os quais Carl G. Jung em sua obra: "O Homem e seus símbolos". assim se expressou:

"O arquétipo é, na realidade, uma tendência instintiva, tāo marcada como o impulso das aves para fazer seu ninho ou das formigas pa ra se organizarem em colônias... E preciso que eu esclareça, aqui, a relaçāo entre instinto e arquêtipo. Chamamos instinto aos impulsos fisiológicos percebidos pelos senti dos. Mas, ao mesmo tempo, estes instintos po 'dem também manifestar-se como fantasias e revelar, muitas vezes, a sua presença apenas através de imagens simbólicas" (Jung, p. 69).

A territorialidade é base para a reprodução da vida animal, quando invadida ou destruida, a espécie. é destruída ou mutilada. O homem ainda é instinto, e portanto submetido às mesmas leis. 0 fato de ter alcançado níveis de abstraçōes lógicas não nega aquela sua natureza primitiva . Ao homem foi dado no percurso das conquistas históricas a capacidade de se sobrepor às dificuldades do meio, porém,is to não significou que o mesmo tenha ficado insensível às rupturas com seu território. Para Friedmann, as relaçōes en tre o homem as mudanças técnicas, as coisas se colocam da seguinte forma: 
"() novo mejo estende em torns do humem umn rede cada vez mais cerrada de estimulaçōes, de solicitaçōes ocasjonais ou permanente, de condiçōes de existência profundamente modificadas em comparação com a de seus avós: ninguém pode duvidar que seu psiquismo, e particularmente, suas maneiras de sentir,de perceber, de imaginar, de querer, não tenham sido atingidas pela pressāo tão rica e variada do meio assim transformado pela necessidade incessante de reagir a ele. Na literatura européia e norte-americana, um grande número de obras - romances, novelas, poemas - traduzem em personagens, situaçōes e sentimentos, as desadaptações e os desequilíbrios significativos, oferecem inúme ras anotaçōes sutis sobre a mudança psicoló gica do homem moderno, os problemas e ruptú ras, os dramas que the são por vezes insepa råveis". (Friedmann, p. 34).

Para podermos falar de un Bexiga que ficou no imaginário das pessoas, teremos que forçosamente trabalhar com $a^{\prime}$ instância das transformaçōes que ocorreram no nível da vida material do lugar, mas também, com todas aquelas imagens simbólicas que as pessoas remanescentes, em um sentimento de saudosismo, tentam perpetuar, permitindo - florescimento daquelas ideologias que muitas vezes inte ressam ao estado è pequena burguesia local.

Como jā apontamos, a década de sessenta max cou 0 inicio de novos tempos para o Bexiga. A população se viu sacudida e acordada de un longo sono. São Paulo tinha que "vestir roupa nova" para receber o "progresso" indus trial. 0 estado passou a interferir na produção do novo es paço urbano. Até aqui, a participaçāo do Estado nesta produção, havia se apresentado de forma menos presente e des- 
continua. Com a intensjficasào do modelo cconómico que tjrou o brasil da condição de cconomia agro-exportadora,trang formando-a numa economia industrializada, as relaçōes estado-economia alteraram-sc. Francisco de 01 iveira nos coloca a questão da seguinte forma:

"Em chegando, O Estado cria-1hes as condições para um desempenho oligopolista: mercados cativos protegidos por altas barreiras alfandegarias, créditos a juros negativos,ex pansão das empresas estatais fornecedoras de insumos básicospara propiciar-1hes os elemen tos do capital constante... A burguesia nacional se desnacionaliza, não apenas nem principalmente do ponto de vista da propriedade do capital, mas sobretudo do ponto de vista de um projeto de nação". (01iveira, p. 71).

0 poder do estado fez-se sentir nāo somente através dos estímulos que deu ao setor empresarial privado. fosse ele nacional ou multinacional, mas também como empreendedor aliado destes dois ültimos. Portanto, nāo podemos pensar quaisquer mudanças da realidade brasileira que não tenham a partir desta época a participaçāo do Estado. Sua presença fez-se sentir fortemente através da política salarial, favorecendo o processo de exploração e acumulação da mais-valia. Sobre a natureza da urbanização capitalista,Sér gio S. Lima fez a seguinte observação:

"Assim, podemos considerar a urbanizaçāo como processo que estruturou o espaço. tendo em vista a reproduçāo simples e ampliada da FT: o conjunto das práticas chamadas urbanas conota a articulação do processo ao conjunto da estrutura social: "De maneira geral, os elementos da reprodução simples da FT são habitaçāo e suas infra-estruturas. Os equipa 
mentos da superestrutura (escolas, cqujpamen tos culturais ( sociais etc) constituem os elementos da reprodução ampliada... do ponto de vista espacial, as necessidades dos traba 1hadores, em matéria de habitação, transporte, equipamentos coletivos, dependem da lógi ca capitalista de localização/rentabilidade das empresas e das atividades de produção,es pecificamente do comportamento das ativida des imobiliárias". (Souza Lima, p. 85).

No que se refere ao comportamento daquelas atividades imobiliárias o Estado contribuiu enormemente favorecendo a especulação, principalmente na expansāo da peri feria das grandes cidades.

Este capitalismo com crescente participação do Estado no processo da urbanizaçāo, foi para o Bexiga em 1968 seu "ano zero". O projeto elaborado para a cidade de São Paulo sob o título de "Anel de Estacionamento do Centro 1" veio marcar uma remodelação paisagística profunda para - bairro, assim como redefinir as relaçōes sociais dentro do mesmo. Iniciado em 1968 está ele hoje implantado em vārios níveis: via expressa passando sobre a Av. Nove de JuIho e rua Santó Antonio, continuando pela rua Jaceguai, indo além da av. Brigadeiro Luiz Antonio, interligando-se num complexo viārio em direção à zona leste da cidade; implantą çāo de estacionamentos nas partes inferiores dos elevados desta via expressa, nas āreas junto às ruas Jaceguai e Santo Antonio.

Quando foi elaborado este projeto, assim se expressou Jorge Wilheim sobre a viabilidade do mesmo:

"Contudo caso se comprove a excelência do traçado, será necessário verificar qual o 
uso a ser dado a algumas ampjiacōes da zona do "Centro $1 "$, constitujdas por trés zonas atualmente ocupada de forma indisciplinada. irregular e antiquadas: parte do Brás (perto do leito da E.F. Central do Brasil), parte da Santa Efigênia (a famosa "boca do crime)e grande parte da densa Bela Vista. Estas zonas, incorporadas pelo anel ao "Centro 1 " po derão ser alvo de estímulos diferenciais,pro movendo-os a funçōes novas, atualmente insus peitáveis". (Wilheim, p. 32).

Neste discurso de justificativa do projeto que revolucionou o Bexiga, percebemos que o comprometimento do autor com o "progresso" acabou colocando-o numa posição equivocada e mesmo perigosa com relação à "preservação" da memória da cidade". Assim, o que for antigo poderá ser clas Sificado de "antiquado e irregular". Uma questão de semântica ou de ideologia? As grandes obras urbanisticas implantadas pelo projeto, inevitáveis ou não, acabaram jogando por terra uma das partes mais tradicionais do Bexiga. 0 referido projeto ainda previa o seguinte: implantação de grandes garagens de estacionamento, super-mercados e demais comércios de abastecimento, eventualmente escritórios, postos de embarques, agências municipais etc. 0 que nos permi te concluir que o Bexiga colocou-se especialmente em um lugar estratégico para abrigar novos equipamentos necessários à expansão física do centro da cidade, comprometendo mais ainda a preservaçāo do que restou do seu patrimônio cultural.

Estas grandes obras de engenharia urbaria mutilaram o bairro. Parafraseando Bachelard, diriamos que o Bexiga "passaria a fazer parte dos lugares físicos da nossa vida intima... de um ser que nāo quer passar no tempo". 0 
hajrro pagou o preço do "progresso". Inúmeras desaproptiacões desfiguraram sua paisagem cexpulsaram parte significativa de scus antigos moradores. Entre sessenta e inicio de sctenta a maior parte do bairro transformou-sc em um "canteiro de obras". Pelas ruas do Bexiga a visão era de casas mutiladas. Das antigas construçōes de frentes estreitas e fundos longos, sobravam somente as partes construidas nos fundos dos lotes, muitas vezes colocadas em niveis eleva dos em relação à rua, com a qual passaram a ser ligadas por escadas improvisadas, feitas de madeira. Este quadro se repetiu por várias ruas dentro de um dos seus limites mais tradicionais, até que, com o tempo, estas "cicatrizes" se fecharam com novas construçōes, deixando, porém, na paisagem as marcas da mutilação, visto as novas construçōes imprimirem um visual arquitetônico desfigurado em relação ao conjunto restante.

As áreas que mais sofreram com a implanta çāo do projeto da "avenida perimetral", também chamada de "Anel de Estacionamento do Centro l" foram aquelas localizadas entre os quarteirōes compreendidos pelas ruas Conse Theiro Ramalho, São Domingos, Manuel Dutra e Rui Barbosa . Alēm, da desfiguração da paisagem urbana, a intensidade e direção dos fluxos viārios foram profundamente alterados pela novas obras de engenharia urbana. A abertura da rua Rui Barbosa como via de ligaçāo entre a avenida perimetral do novo projeto ao bairro do Paraiso e outros situados alé do espigão da Paulista, significou profundas mudanças nas comunicaçōes e trânsito dentro do Bexiga. Dois grandes eixos de circulaçāo passaram a cortar o Bexiga na sua parte interior: o eixo leste-oeste representado pela perime tral e norte-sul pela nova Rui Barbosa. O primeiro, ras- 


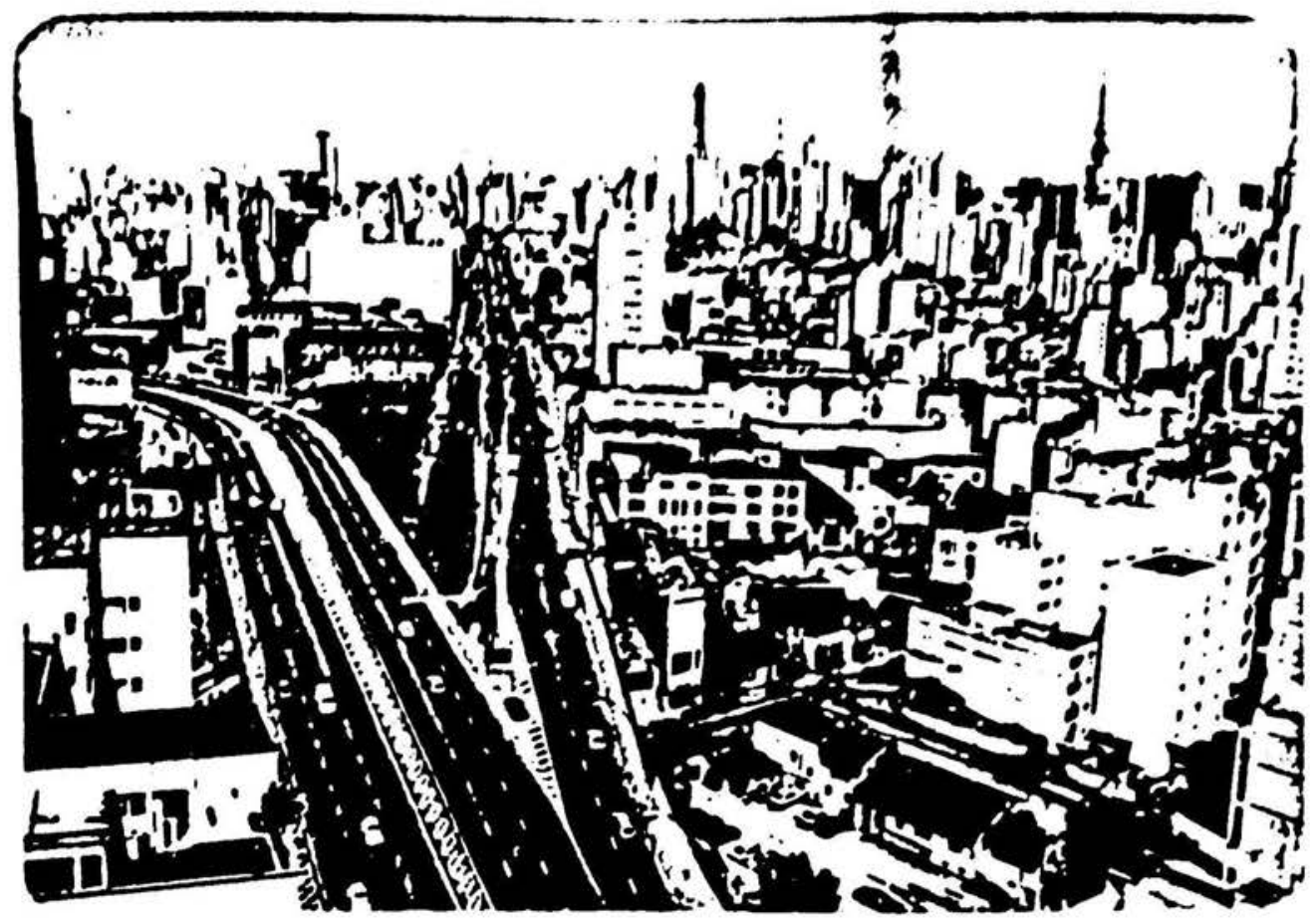

Foto 3: Anel de estacionamento do Centro 1 e a "nova Rua Rui Bar bosa" (seguindo para a região do espigão da Av. Paulista plano de fundo da foto). (Ano 1988)

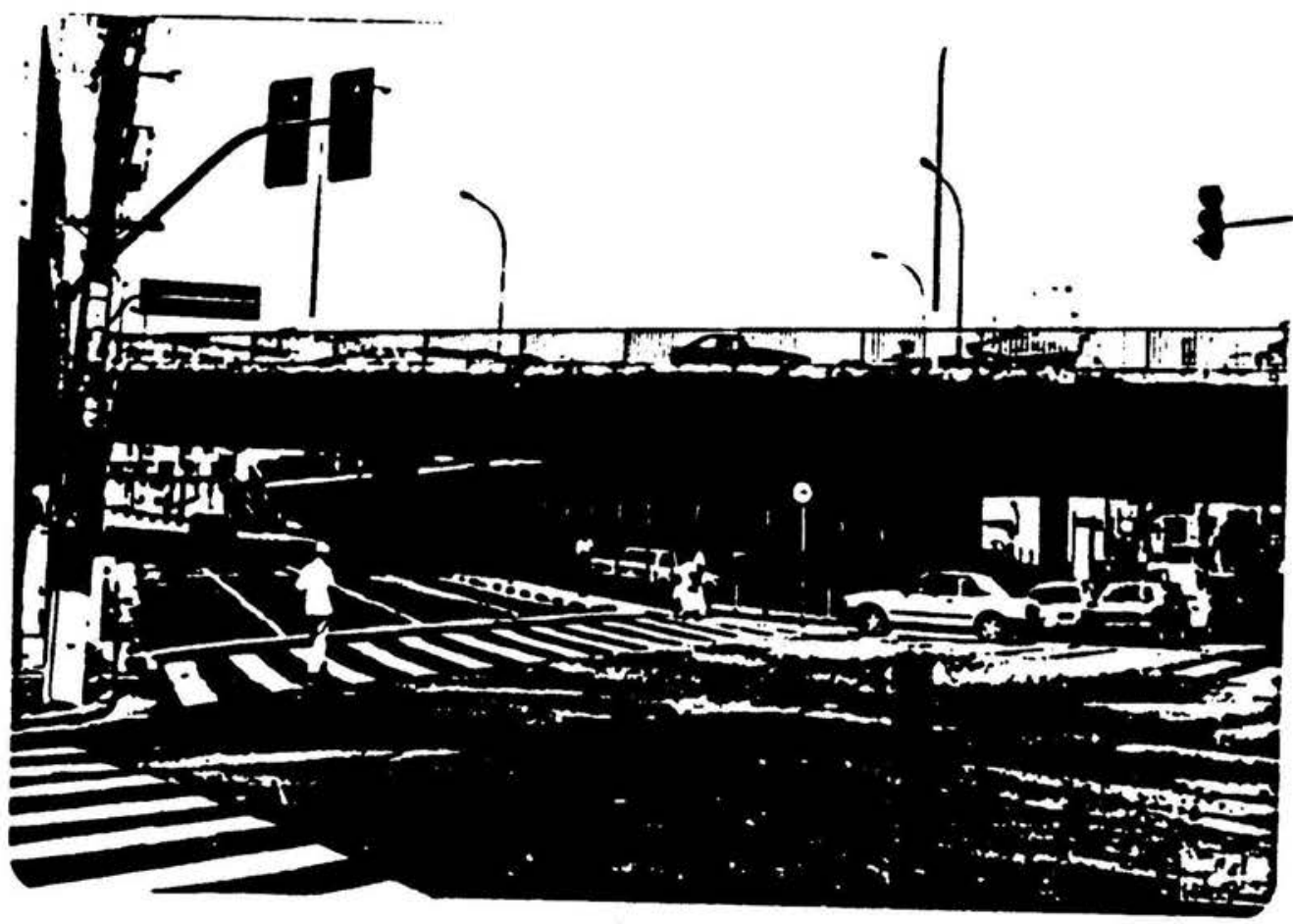

Foto 4: Parte inferior do anel de estacionamento do Centro I passando por sobre a rua Santo Antonio. Area antigamente ocu pada por casaröes. (Ano: 1988) 
gando simpjesmente a pajsagem c n vida do bajro, onde a pos sibilidade de ocupaçào c uso por edifjcaçôes tornou-sc prat camente impossivel, visto na sua maior parte aprescintar.se em forma de elcvados, tornando-se assim uma obra que não per mitiu sua reintegração ao tecido urbano local. 0 segundo,que pouco guardou daquela velha e tradicional rua, hoje redefine "novas" formas de uso do solo: casas de diversōes, cantinas, um "terciário informal".

Estas duas vias interromperam as 1 igações entre diferentes pontos do Bexiga. A perimetral leste-oeste seccionou a rua São Domingos em duas partes incomunicáveis , representando uma "grande muralha" entre as duas partes remanescentes. 0 mesmo aconteceu com a rua Conselheiro Ramalho. E importante lembrar que a rua São Domingos sempre representou uma importante via de ligaçāo entre a parte baixa da rua Treze de Maio na confluência com a rua Santo Antonio com outro tradicional núcleo histórico da rua Abolição e Major Diô go. A Conselheiro Ramalho, totalmente interrompida, represen tava uma importante ligação entre a Av. Brigadeiro Luiz Anto nio e a rua Santo Antonio. Mais do que uma interrupçāo na circulaçāo viāria, isto significou o isolamento destes núcleos onde sempre existiram fortes relaçōes de vizinhança, Além de representar um obstáculo físico funcionando como "muralha", esta via pelo fluxo de automóveis e pela velocidade dos mesmos separou velhas partes do Bexiga. Com relação à nova Rui Barbosa, a coisa nāo foi diferente. Tendo sofrido $\underline{i}$ númeras desapropriaçōes, desfigurando-se e expulsando seus moradores do bairro, foi transformada numa grande avenida, seccionando e tornando incomunicāvel as duas partes da rua Fortaleza. Esta última, representava um elo na ligação entre 


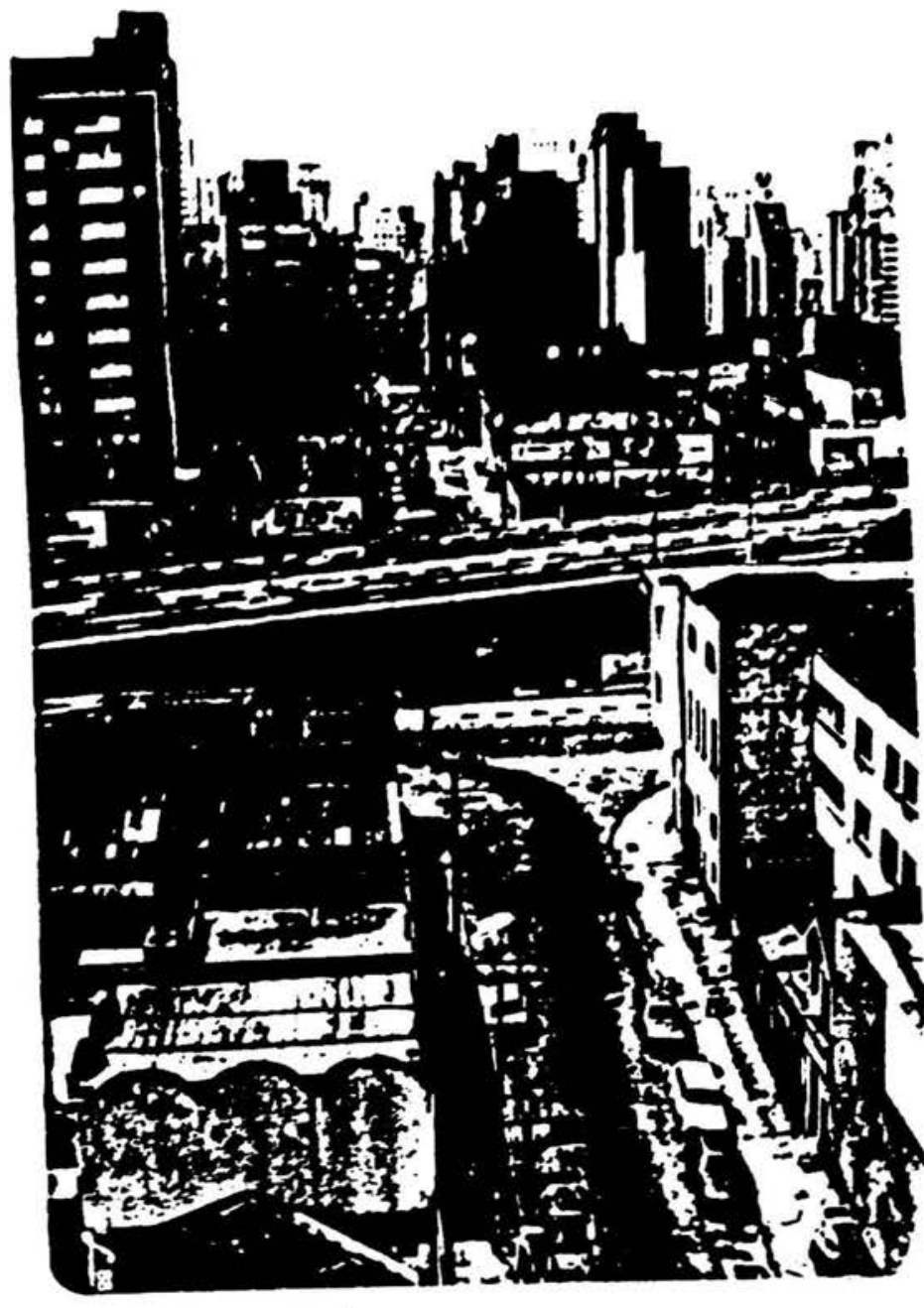

Foto 5: Rua São Domingos. Ho cortada pela "nova $R$ Rui Barbosa". Uma di multas vias obstruidi pelas obras de reurba nização. (Ano: 1988)

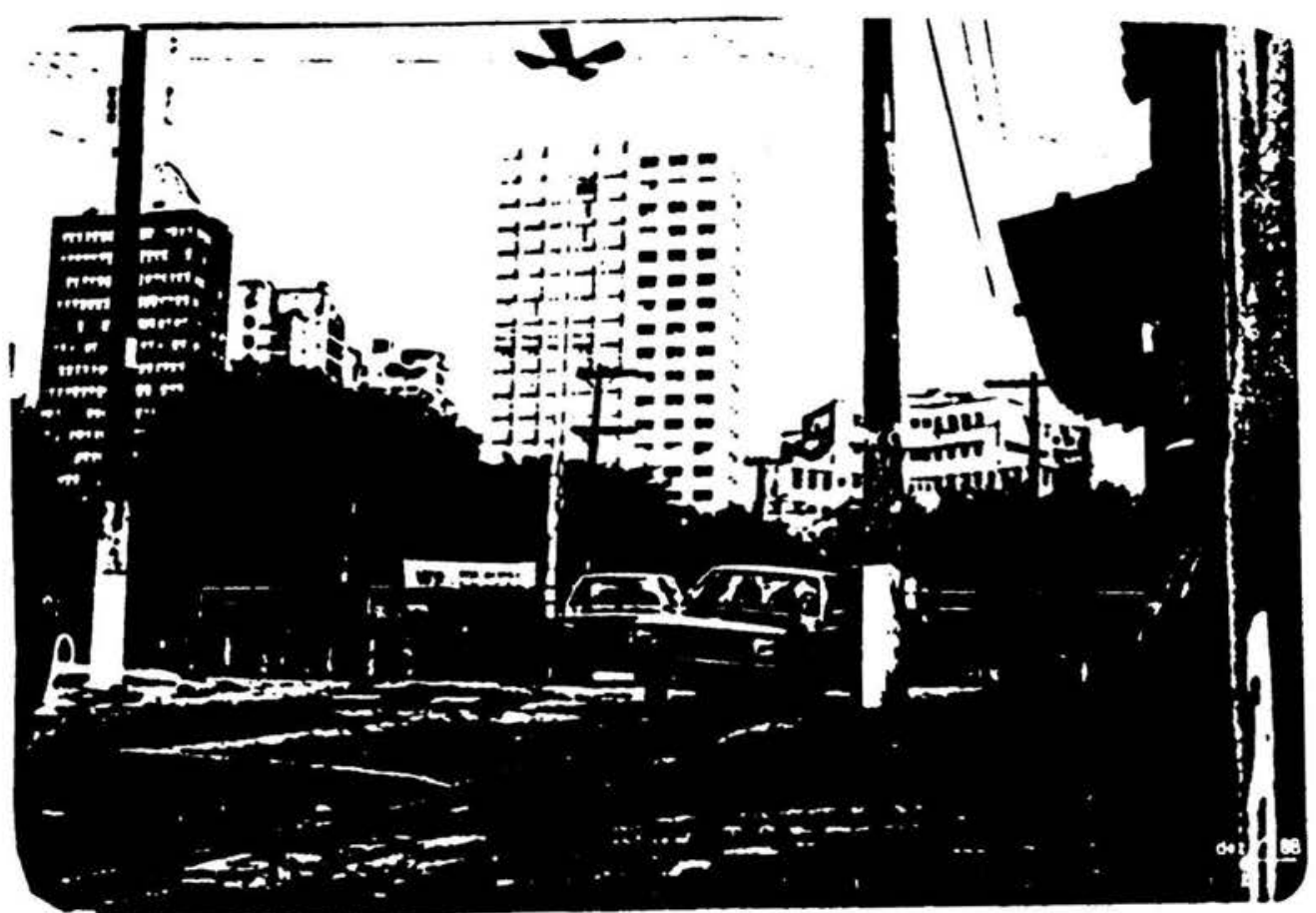

Foto 6: Paredão formado pelo leito da "nova rua Rui Barbosa". No plano de fundo da foto o Morro dos Ingleses, onde está localizada a escadaria de acesso ao mesmo. Hoje obstruida na ligação com o Morro dos Ingleses pelo "paredão" por nös chamado de "Muro de Berlim". (Ano: 1988) 
aquela que podemos consjderar a majs tradicjonas vija do Pe xiga - a Vila Antunes com a rua Treze de Majo.

O Bexiga expandiu-se do velho piques para as vertentes do espigão da paulista, quando se iniciou o presente século. Acompanhou a expansão dos antigos trilhos dos bondes :

"Os bondes elétricos, sendo um transporte co letivo que necessita de uma rede de trilhos e da linha elétrica para funcionar, só podem operar eficientemente com uma alta frequên cia de uso de suas linhas. Ou, para ser mais preciso, a sua alta composição orgânica de capital, determinada pelo alto custo da instalação das redes em relação aos custos de manutenção e operaçāo, exige uma intensa ut $\underline{i}$ lizaçāo das redes, impedindo uma prolifera ção de linhas com baixo potencial de uso, a não ser quando a prōpria empresa tivesse um interesse especial na extensão, visando a va lorização de determinada área ou quando á extensão das linhas fosse paga pelo loteador, como foi o caso da Cia. City no loteamento dos Jardins" (Bonduki).

0 Piques, naquela época, era o ponto de partida de importantes linhas de bondes que ligavam o centro da cidade aos bairros localizados da sua parte sul, a exemplo dos bairros Jardins. A rua Sto. Antonio fazia a ligação do vetho Piques com os novos bairros representando em Sāo Paulo um dos grandes troncos de ligação viária; assim acontecia com as ruas Major Diogo, Conselheiro Ramalho, Rui Barbosa. Manuel Dutra e São Domingos. Quando os trilhos foram arrancados pelos idos de sessenta, aquelas 'ruas que ainda guarda ram um pouco da sua "majestade" pela importância que o bonde thes atribuia, foram rapidamente mutiladas pelas grandes 
obras daquele projeto. Os bondes representoram para o Picxiga um importante instrumento de vajorizaşäo dos lotes no processo de produçāo deste espaço, levando também, à enorme procura para aqueles cortiços que proliferaram pelo "modesto" bairro, visto a facilidade de ligação que os mesmos permitiam com outros pontos importantes de São Paulo.Co mo podemos ver, aquelas ruas, hoje mutiladas $j a ̈$ representaram importante papel dentro do Bexiga.

No conjunto de transformaçōes que a cidade de São Paulo fosse pela expansāo horizontal, na ampliaçāo de uma periferia que se colocava cada vez mais distante do "an tigo centro" ao qual o Bexiga estava intimamente ligado,fos se pela verticalizaçāo, o que significava um adensamento contínuo daquele centro, o bairro do Bexiga viu-se mais uma vez, neste período analisado, atingido na sua estrutura urbana. A necessidade de São Paulo estabelecer ligaçōes cada vez mais amplas com sua periferia e outras partes interme diárias entre aquela e o centro, acabou, nāo somente, levan do à construção de vias expressas, como tambēm, redefinir as formas de uso de avenidas aristocráticas com uso residen cial para corredores de circulaçāo, sendo invadidas por atividades de serviços e pelo comércio. No caso.do Bexiga as principais avenidas atingidas foram a Av. Nove de Julho, a Av. Brigadeiro Luiz Antonio.

A primeira, a partir da década de śessenta deixou de ser um belo logradouro público para se transfor mar em uma via de grande fluxo. Suas calçadas, anteriormente largas e espaçosas foram sacrificadas para o alargamento das pistas para facilitar o amento no fluxo de automóveis. que demandavam os aristocráticos bairros jardins na zona 
su1, come também. de um enorme númeto de Jinhas de ônibus que se dirigiam à nova periferia formada por um grande número de "vilas proletárias". O antigo Piques, hoje Pça. das Bandejras, em lugar do largo dos bondes, passou a abrigar dezenas de pontos de ónibus que demandam à zona sul passando pe10 Bexiga. Esta avenida quase chegou a transformar-se em uma via de ocupação residencial de camadas da classe média alta. A presença de alguns prédios antigos voltados para esta clas se, nas proximidades do espigão da Av. Paulista e alguns outros dispersos pela mesma, testemunham esta tendência "abortada". A segunda avenida, foi a av. Brigadeiro Luiz Antonio, da mesma forma que a anterior, foi também sacrificada no seu paisagismo. A medida em que se transformou num corredor de circulaçāo em direçāo à Paulista e zona sul da cidade, foi abandonada pela aristocracia que ocupava os casarōes das prí meiras décadas deste século. Em lugar de uma via residencial transformou-se em lugar de formas muito variadas de uso, des de oficinas mecânicas, lojas de móveis usados, pequenos super-mercados, estacionamentos, bares, lojas de eletro-domésticos, casas de diversōes, como teatros e cinemas, bancos, co mércio em geral. Os antigos casarōes acabaram transformandose em cortiços, alguns em hotéis, outros foram demolidos dan do lugar a pátios de estacionamento. Hoje presenciamos algumas tentativas de penetraçōes de edifícios mais modernos para fins institucionais.

Paralelamento à transformaçāo destas vias em grandes corredores de circulaçāo, interligando-se num grande sistema com a "Perimetral - Centro l" e nova Rui Barbosa, as vias internas do bairro viram-se também atingidas. As ruas de paralelepípedos transformaram-se em ruas asfaltadas, com seus leitos alargados e calçadas comprimidas para dar maior 
vasão vo fluxo de automóveis, numentados em razão das inter ligaçōes viärias feitus com aquele grande sistema viário. Co mo obras complementares de engenharia urbana foram construí dos mais dois elevados dentro do bairro para facilitar a es coamento do fluxo. Foram eles: o elevado sobre a av. Brigadeiro Luiz Antonio e olevado sobre a Pça. Quatorze Bis,na av. Nove de Julho. O primeiro, construido para fazer liga çāo entre a nova Rui Barbosa e a rua Treze de Maio. O segun do, para permitir as conversōes no trânsito daqueles que vem da av. Nove de Julho em direçāo à rua Rui Barbosa e o "Anel do Centro 1". Estes dois elevados colocam-se dentro do bairro como enormes massas de concreto, poluindo o visual do pedaço. Assim, como aquelas outras obras, apresen tam-se, também, como "agressores" de espaços. Colocando-se em niveis superiores aos apartamentos e casas situados nas ruas laterais, invadiram a intimidade dos mesmos, inclusive criando uma situação de forte poluição pela fuligem que invade residências colocadas abaixo do piso do mesmo. Estes representaram as alternativas técnicas que o planejamento urbano encontrou para resolver o problema do trânsito, dentro de um bairro que ficou enclausurado entre grandes vias que cortam e ligam aqueles diferentes pontos da cidade. Solução que mais uma vez acabou significando mutilação.

0 acelerado ritmo de mudanças no espaço fís $\underline{i}$ co do Bexiga veio acompanhado tambēm de mudanças nos componentes sócio-espaciais. 0 compasso na mudança destes dois niveis da realidade geogräfica apresentaram-se diferentes. 0 primeiro foi relativamente rápido, como produto da interven çāo do planejamento acelerado imposto pela administração pú blica, impelida pelas transformaçōes da sua economia. Os primeiros anos da década de setenta jå praticamente marcavam 
- concjusño do grande ciclo das mudanças no cspaco físjco.o scgundo vejo em ritmo mais 1 ento e prossegue nos dias de hoje. Se as mudanças ocorridas no nivel fisico foram importantes para que ocorressem as mudanças sociais, devémos, porém, ressaltar que as segundas foram mais significativas, pois atingiram o bairro na sua essência.

Paralelamente à abertura das grandes vias expressas ocorreram aquelas desapropriaçōes em escala numerosa, forçando a mudança de uma parcela significativa da po pulação tradicional do Bexiga. Em todos os depoimentos realizados sobre o bairro, houve unanimidade em apontar esta retirada em massa como um dos grandes fatores de mudanças para o Bexiga. O deslocamento pelas desapropriaçōes de centenas de familias tradicionais do bairro, afetou a vida do bairro. Antigas relaçōes de vizinhanças que davam vida a muitas localidades, foram destruídas.

o Bexiga nä́o podia continuar o mesmo com as mutilaçōes que ocorreram naqueles "lugares comuns" - lembrando Bachelard: esquinas, vilas barbearias, sapatarias,ci nemas etc. Mais do que lugares físicos, eram pontos de encontro, lugares de "bate-papo" que funcionavam como lugares de circulação nas informaçōes - as "fofocas do bairro". Estas relaçōes foram quebradas. Fisicamente estes pontos foram arrasados. Quando da realização das entrevistas se inda gava sobre os lugares que tinham simbolicamente maior repre sentatividade para o"velho bairro", a primeira resposta era de que as "grandes obras" os haviam destruídos, apontando-se alguns lugares, que segundo eles, ainda haviam sobrevivido à grande demoliçāo. Esta parte serā aprofundada em outro capitulo do trabalho. 
Com o surto da grande industrializaçio que atingiu Säo paulo no interior de um capitalismo que acentua va as desigualdades regionais e sociais, a cidade viu-se ca da vez mais ocupada por levas de imigrantes nordestinos. (O Bexiga pelas condições que apresentava como bairro acahou recebendo um contingente muito grande dos mesmos. A população de italo-paulista que sempre fora dominante, passou a diminuir cada vez mais. A medida que as velhas familias abandonavam o bairro "voluntariamente" ou expulsas pelas desapropriaçōes, aqueles nordestinos foram gradativamente ocu pando seus "lugares".

Entre aqueles fatores "voluntärios" estavam os seguintes: A renovação de filhos e netos que passaram a ascender socialmente, dando preferência a outros bairros mais nobres. As mortes dos proprietários representativos dos antigos povoadores que deixavam como herança não somente os imöveis, mas, também, complicados processos jurídicos de partilha nesta herança. A perspectiva de saida do imóvel e do bairro daqueles herdeiros em melhores condiçōes sócioeconômicas colocou-se como alternativa. Alguns permaneceram, mas, a dispersão de um número muito grande de proprietärios sobre um mesmo imóvel e a perspectiva de verem no mesmo uma possibilidade de futuros ganhos pela valorização que o cres cimento da cidade oferecia, levou a maior parte destes proprietários a apostar na especulaçāo e menos na sua preserva çāo, o que acabou levando a uma rápida deterioração dos imó veis, tanto pelo descuido na reparação física como pelo processo de fragmentação destes em inúmeros "cômodos". Esta fragmentaçāo ocorria pela açāo direta dos seus proprietários ou à revelia deles, permitindo a seus inquilinos que sublocassem aqueles espaços a terceiros. A chegada dos 
nordestinos ocotreu no interior deste processo pejo ques passava o bajro. Isto contribuju quet para uma major deterioraçāo dos cortiços. já tradicionais dentro do bairro des de aquele tempo majs antigo, quer para a criação de novos.

Paralelamente às transformaçōes físicas que ocorreram no espaço tivemos, pois, profundas alterações no nível daquelas relações sócio-econômicas e mesmo culturais no bairro. Para uma população de trabalhadores - artesãos e autônomos - "biscateiros", provenientes daquelas populaçōes tradicionais, que tinham no bairro parte significativa de uma clientela cativa, a presença dos nordestinos, onde muitos dos quais procuraram sua sobrevivência naqueles tipos de serviços, significou uma forma de "usurpação". Por outro lado, os pequenos negociantes, há muito tempo ai estabelecí dos, passam a ver no aumento da offerta de māo de obra uma ótima oportunidade para tirar proveito na barganha da mesma no mercado de trabalho, aumentado pela população alienígena assalariada. Qualquer recusa por parte dos mesmos em acei tar as propostas dos empregados, era tida como manifestaçāo de um caráter indolente e comportamento de vadiagem. Neste momento, apontavam as precárias condiçōes em que viviam - os cortiços, como produto de uma "inferioridade culturai".

Para a populaçāo tradicional, a chegada do nordestino passou a ser considerada como uma das causas importantes na perda da identidade cultural do Bexiga. Idéia esta que acabou se difundindo por outros segmentos da população do bairro e mesmo no interior da grande cidade. Assim aqueles artesãos, autônomos e negociantes e a população tra dicional em geral, partilhando da mesma ideologia, impeli dos pela competição crescente do "novo capitalismo" que im- 
punha uma nova divisáe social do trahalho c conscquentemen te novas rejaçóes sociajs, acabaram revelando um verdadeiro xenofobismo para com os mesmos. Passaram a se comportar como uma "minoria" retrograda a desfraldar a bandeira do italo-paulistanismo. Fato este que não se consumou somente no interior do Bexiga, mas de uma forma geral, em toda São Paulo quando da chegada dos chamados "paus-de-arara".

Se o "ano zero" acabou caracterizando para - bairro um processo de grandes renovações urbanisticas, dando início à formação de um "novo bairro", a l terando suas formas de usos e costumes, cabe-nos, aqui, verificar, quais são as tendências que estão se definindo hoje em lugar daquelas.

\subsubsection{Tendências atuais nas formas de uso do solo}

0 bairro do Bexiga é hoje caracterizado pela predominância da função residencial. Pelos dados obtidos na presente pesquisa registramos $59,3 \&$ do total das ocorrências no uso dos lotes para as funções residenciais. Quan to ao terciário, este vem em segundo lugar, assim, distri buido: 21,3 \& para as atividades de serviços e para as de comércio, 15,78. O setor secundärio tem pouca presença den tro do bairro, representando somente 3,58. Quanto à nature za das atividades de serviços aí encontrados, na sua maior parte refere-se a um "terciārio informal" de baixo nível de qualificação, estando representado em 47,18 do seu total pelas seguintes atividades: consertos de aparelhos eletrodoméstico, consertos de automóveis, serviços de restaura çōes de móveis e objetos em geral. A quase totalidade des- 
tes serviços são roajizados cm instalaçöes improvisadas cm ontigas casas c partes inferjores de piedios residencjajs ou em terrenos vazios. Além destes serviços de consertos, en contramos, também, pequenos escritórios de "despachantes". Quanto aos setores de comércio, $53,5:$ são constituidos por pequenas lojas: "armarinhos", bares, quitandas, padarias e pequenos armazéns. As lojas de maior porte, correspondem a 9,: 8: lojas de eletro-domésticos, roupas, ferragens, de aparelhos técnicos de som, papelarias e lojas de material óp tico e fotográfico. Além destas atividades de comércio, que expressam pela aparência e movimento de vendas, maior porte, devemos destacar, pelo grau de concentração, a atividade co mercial das cantinas e pizzarias, com 11,08 do total do comércio do bairro, atividade voltada para uma clientela que, na sua maior parte, localiza-se fora do mesmo.

No setor de serviços queremos destacar aqueles que se apresentam com concentraçāo bem significativa, is to é, os relacionados às atividades de diversōes e lazer, tais como, cine-clube, teatros, casas de show, música-bar. perfazendo 13,58 do total de serviços.

Estas atividades ligadas às cantinas e às $\mathrm{p} \underline{i}$ zzarias bem como às diversões ou lazer, apesar de representarem juntas somente 24,58 das formas de uso, podem ser consideradas como vitais para a caracterização do bairro, nāo somente por se destacarem no conjunto do terciário de forma mais concentradas, ou seja, por apresentarem-se com maior frequência em um conjunto muito "pulverizado" de atividades, mas sobretudo por representarem aquele fator deter minante na caracterizaçāo funcional do bairro no conjunto da cidade. fato este que se expressa no grande número de populaço flutuante que atrai nos periodos noturnos e fi- 
nais de semana, representande por isso "cartäe postad" ven dido para fora do mesmo. Inquanto o numero de cantinas cresceu entre 1974 e $1978 \mathrm{~cm} 1,18,0$ de casas de diversōes noturnas cresceu em 4,08 .

Deve-sc destacar, também, o crescimento de um setor do terciário que hoje cada vez mais começa a tomar conta do bairro - os grandes escritórios e os bancos. representando $j a ́, 10,8 q$ do total de atividades de servi ços registrados. A representatividade do setor industrial, é pequena. Somente 3,58 dos registros incidiram sobre a ocorrência de estabelecimentos industriais, assim mesmo de pequeno porte, como: pequenas indūstrias de móveis, grāficas, algumas sendo gráficas e editoração, de sapatos e se $\underline{r}$ ralherias. As primeiras com 31,08 do total das indústrias, as segundas $\operatorname{com} 27,58$ as terceiras $\operatorname{com} 11,38$ as últimas com 10,08 . O restante é representado por indústrias de confecções, hoje reduzidas no bairro, alimentícias, etc.To das elas com fortes vínculos na história da ocupação do Bexiga, além de representarem hoje, como antigamente, atividades de atendimento da "zona central" da cidade.

0 crescimento dos setores de serviços ligados às diversões noturnas e às cantinas acabaram definindo um processo de especializaçāo no uso do solo do Bexiga. 0 setor de diversões fixou-se inicialmente na parte baixa da rua Treze de Maio, na confluência com a rua St. Antonio,en quanto as cantinas nas imediaçōes da Igreja de N.Sra. Achị ropita. Segundo depoimento de líderes do bairro, acabaramse configurando dois polos "contraditórios" para a histó ria e tradições do bairro. As cantinas representando "aqui 10 que de "melhor" possui o bairro - sua ltalianità, frequen tada por familias de "respeito", enquanto a outra, o símbo 


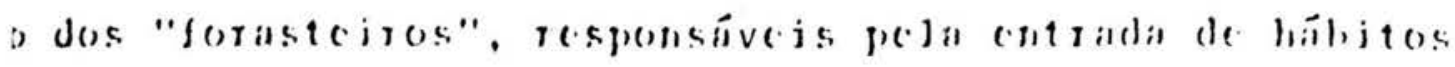
estranhos" à vida do pexiqu".

A transformaçáo das residencias coll novas ormas de usos no bajrro, após os anos sessenta, foj mujto requente. 18: das mesmas se transformaram de uso residenial para uso misto, segundo os estudos da COCEP/1974. Na lerdade este foi um fenómeno contínuo até recentemente. Na naior parte estas residencias foram ocupadas pelas novas funções turísticas - teatros, casas de diversōes noturnas, bares de encontro, cantinas e pizzarias e por negócios em geral, atraindo uma população flutuante e com ela um aumen to muito grande do número de carros que passaram a ocupar as calçadas e ruas dos locais próximos daqueles estabelec $\underline{i}$ mentos de lazer e diversões. Os moradores, principalmente aqueles representados pelos grupos tradicionais do bairro, viram-se "violentados" pelo "barulho" e perda da "segurança". Segundo os mesmos, o bairro havia sido invadido junta mente com "aquelas casas de diversões" por "trombadinhas e marginais". Os carros passaram a congestionar as ruas e com eles sobre as calçadas, dava-se a obstrução de entra das de residências e garagens dos automóveis dos seus mora dores que acabavam ficando "enclausurados". Esta foi uma das muitas causas que levaram antigos moradores a se mudarem para outros lugares do bairro e para fora do mesmo. A pressão muito grande pelas ruas e com elas o baru tho que facilmente penetrava pelo interior daquelas casas com janelas baixas e diretas para a rua, acabou desestrutu rando a antiga vida tranquila do bairro, principalmente da queles quarteirões colocados ao longo da Treze de Maio,Rua Rui Barbosa e Sto. Antonio, antigos redutos do tradicionalismo no Bexiga. O início destas atividades na área foi 
mujto conflitante. Mosadores antigos unjam-se cm abajxo-assinados podinde a remosjo daquesas casas, ou entio pedindo para que as mesmas controlassem o som dos apiarelhos c dos grupos musicais. Não raro era chamada a polícia pelos moradores. Mesmo com toda a resistência daqueles moradores as novas funçōes impuseram-se. Qucm acabou saindo foram os antigos moradores.

Gradativamente, as casas de diversōes instalaram-se naquele pedaço do bairro, ocupando as antigas resi dências. Segundo a COGEP, em 1974, 90 \& destes estabelecimen tos, ali instalados eram alugados. Hoje a situação continua a mesma. Pelos mesmos estudos, a clientela que frequentava os estabelecimentos vinham de outras localidades da cidade. Hoje continua frequente a chegada de caravanas de turistas, que vindos à São Paulo, passam a visitar o Bexiga. A popula ção local dificilmente tem acesso a "esta mercadoria" - fato constatado pelos depoimentos de seus proprietários.

Pela sua tradição, conforme jā foi exposto em capítulo anterior, o Bexiga foi grandemente ocupado por pequenos artesãos e profissionais autônomos. $\AA$ medida que a expansão capitalista ocorreu em São Paulo, impondo cada vez mais as regras do grande mercado, aqueles artesãos acabaram na sua maior parte desaparecendo. Poucos ainda permanecem conforme podemos constatar naqueles setores das indús trias jä arroladas.

Aquela expansão alterou a vida de muitos bairros de São Paulo. Muitos acabaram abrigando indústrias obsoletas. Outros como no caso do Bexiga, com seu artesanato desestruturado acabaram sendo invadidos por um terciário "informal" e por uma populaçāo que passou a procurar o bair 
ro come Jugar de resjelencia em busca de trabalhe ne centro da cidade. Hato este que seguju já umáantjgá tradjaño que a localizaçáo do bairto favorecia. Após as grandes transfor maçōes viárias o bairro tornou-sc atrativo para o grande conjunto los trabalhadores, principalmente para aqueles que não dispōe de automóveis. Scus corredores de circulação co locam-nos em fácil acesso à qualquer ponto do centro, ou da cidade, a pé ou de coletivo (Fig. 8).

São Paulo, com o avanço na "modernização", criou a necessidade de um terciário cada vez mais sofistica do, desde a renovação das instalações das grandes instituiçōes financeiras que ocupavam os antigos prédios sem esta cionamento do "velho centro", até os grandes escritórios de marketing e planejamento, e os novos setores de informática, etc. Seguindo a tendência de expandir-se desde aquele centro, criaram-se novas áreas para integrarem-se ao mesmo como lugar de implantação do "novo terciārio" que demandava novos e arrojados projetos arquitetônicos. A "Nova Paulista" e a av. Faria Lima acabaram abrigando este processo de expansāo. Antigos palacetes daquela aristocrática avenida foram derrubados para dar lugar aos novos projetos. Outros foram remodelados para abrigarem as novas funçōes. O "velho Bexiga" colocado no meio, entre o "velho centro" e a "Nova Paulista", só recentemente começou a receber efetivamente este terciário. Sua estrutura fundiāria, o tipo de vizinhan ça e as condiçōes físicas do lugar, a maior parte com ruas estreitas, etc. levou a um "salto" em direção ao espigão e zona sul da cidade. A reurbanização da Av. Paulista absor veu enormes investimentos públicos para adaptá-la àquelas funçōes, que potencialmente poderiam ser localizadas no Bexiga como "prolongamento natural daquele território do "ve- 
BEXIGA E GRANDES EIXOS DE CIRCULAÇÃO

\section{$\begin{array}{llll}1 & 9 & 7 & 5\end{array}$}

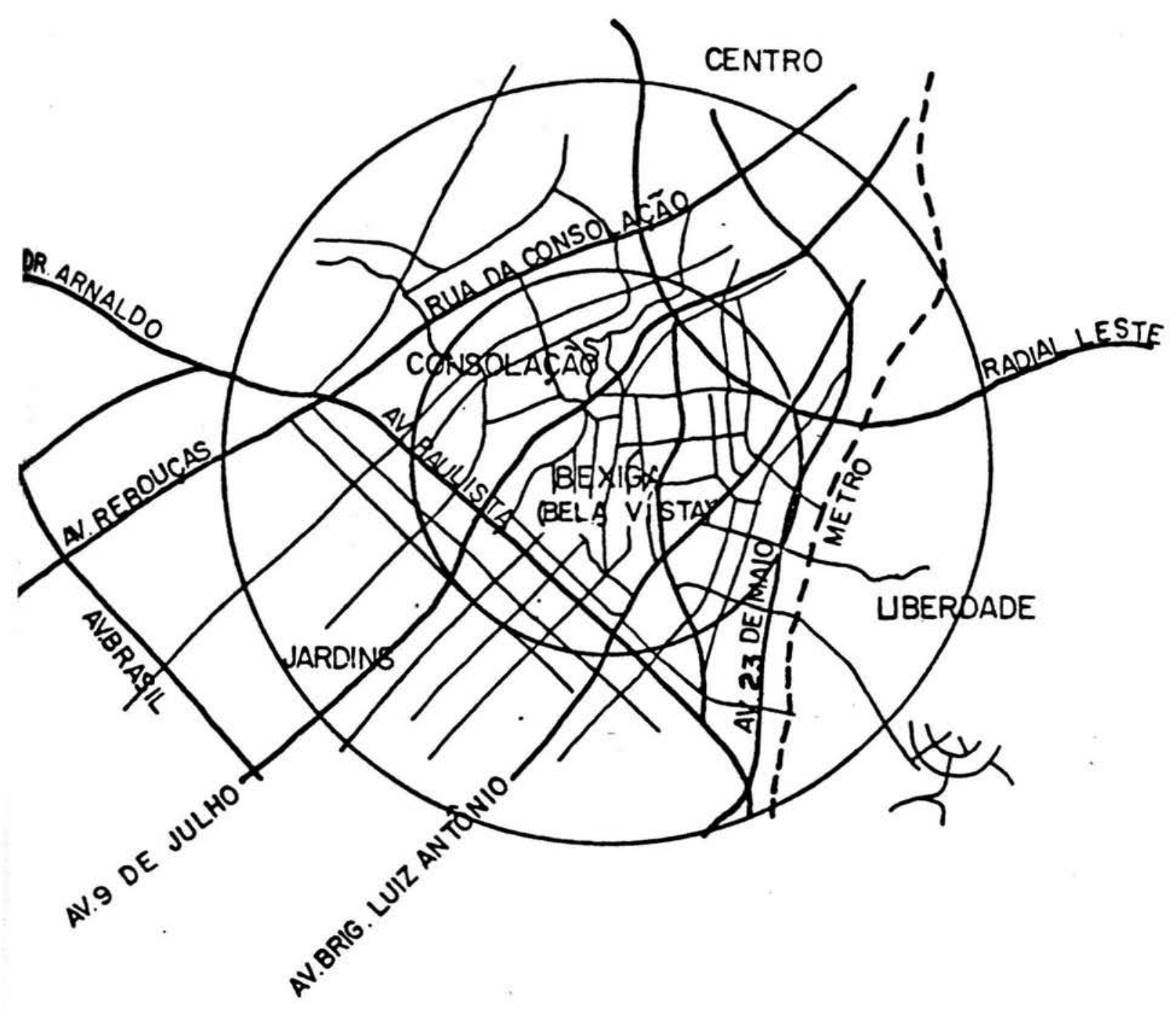

Fonte: COGEP-Coordenodorio Gerol de Plonejomento-PMSP, 1975

Des.: Orito/88. 


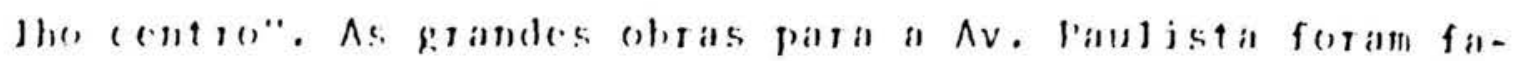
verecidas pejo tipo de estrutura fundjírja. lis grandes jotes colocados ao longo desta via favoreceram claboração daqueles arrojados projetos que recebcram as instalaçocs de grandes bancos e edificios para escritórios. Sua proximidade com os hajros aristocráticos e seu projeto viário como eixo perimetral dentro dos grandes anéis viários projetados para S. Paulo de então, aliados àqueles outros fatores fizeram com que a "Nova Paulista" absorvesse juntamente com a Av. Briga deiro Faria Lima o processo de "modernização do terciário". A criação deste "novo centro", foi altamente estimulante pa ra os grandes empreendimentos imobiliários, públicos e priva dos, dentro da reurbanização de São Paulo.

Como já falamos, o Bexiga, mais recentemente, presencia a implantação do "novo terciário". As avenidas Brigadeiro Luiz Antonio, Maria Paula e algumas de suas transversais são aquelas onde mais se presencia o fenômeno. Também foram observados alguns locais com a penetração de pequenos setores ligados à informática e vídeos no interior das regiōes tradicionais. O prōprio Morro dos Ingleses e seus casarões sendo derrubados para ceder lugar a grandes prédios de escritórios ou então sendo ocupados por estas atividades. Apesar disto, o bairro continua ainda sendo caracterizado pelo "terciário informal". Somente os serviços de consertos de automóveis e estacionamentos, que ocupam fundos de lotes, partes inferiores de casas ou terrenos de casas demolidas, constituem 29,168 do total de ocorrências nas formas de usos. Quanto aos referentes a consertos de aparelhos eletro-domésticos, 6,258. Estas duas atividades so mam juntas 35,418 dos registros de ocupaçōes no total dos 
lotes.

lara comprecndermos a estrutura deste tercia rio no kexiga temos que comprecnder a natureza do processo de reprodução capitalista no país, ou seja como se dá a pro dução, a distribuição c a circulação das riquezas. Vive-se numa sociedade onde o padrão de consumo tenta reproduzir aquelas das sociedades capitalistas avançadas, mas que porém não tem o nível de autonomia no processo das decisōes sobre as taxas de acumulação interna do capital no país. Assim, a política de distribuição da renda, determinada externamente, acaba definindo o potencial de consumo da massa trabalhadora internamente. Os mecanismos de distribuição da renda, de terminados pelos interesses do capital multinacional, influenciadores no potencial de consumo daquela populaçāo,aca bam reproduzindo, aqui, formas de consumo "pervertidas" quan do comparadas com as condições daquelas sociedades desenvol vidas. Enquanto a produção e distribuição de bens de consumo nas sociedades capitalistas "avançadas" pode se colocar no "mundo do descartável", ou seja, o nível de vida média, permite estabelecer tempo relativamente curto para o uso dos produtos, podendo estes serem facilmente trocados por novos modelos - "obsoleto planejado", em sociedades capitalistas como a nossa, o "descartável" torna-se uma "perver são". Assim, temos que apelar para a necessidade de se prolongar ao máximo a vida daqueles bens. Obviamente que, para cada nível de renda esta necessidade estará mais ou menos determinada. Neste contexto é que entendemos o porquê em certos meios a proliferação de "casas de consertos" torna-se maior. A existência de um número muito grande destas casas no bairro do Bexiga tem que ser explicada não em fun- 


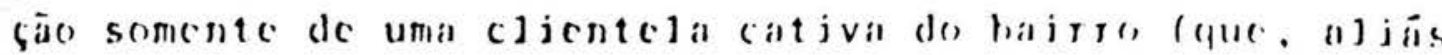
pelos depojmentos dos "pequenos negocjantes" constituj a grande majoria da clientela), mas também de una clicutela que potencialmente é uma parte mais ampla da cidade. llcsta forma, a existéncia deste tipo de terciário revela uma dimensão da natureza do nosso capitalismo e ao mesmo tempo,dá nos a possibilidade de compreensão sobre aquelas formas de uso do solo no bairro.

Aqueles $47,1 \%$, representando os serviços de consertos no conjunto do setor de serviços, apresentam-se no interior do bairro de forma bem dispersa. Como veremos mais adiante, somente na região do alto da grota é que o mesmo não aparece. Nas demais áreas estes tipos de atividades tem presença constante. Representam hoje uma fonte de renda para os proprietários daqueles casarōes ou terrenos que ocupam, pois, na sua maior parte, estes "negociantes" alugam ou sub-alocam estes espaços. Desta forma permitem àqueles uma renda enquanto se dã a valorização do terreno no processo das transformaçōes urbanas da cidade. Ao mesmo tem po, contribuem, juntamente com os cortiços, para o processo de fragmentação no uso dos lotes, criando uma pressão contí nua sobre este espaço. Cada casa e pedaço de terreno se des dobra em infindáveis.tipos de uso estimulando o apetite daqueles que vivem da exploração dos aluguéis.

Excluindo-se aqueles setores que hoje estão gradativamente entrando no bairro, representados pelo terciärio que poderíamos chamar de "superior" grandes escritórios empresariais, bancos, alguns setores de vídeo e informática, o bairro continua sendo ocupado pelo setor "infor mal". E um lugar onde os tipos de empreendimentos caracter $\underline{\mathbf{i}}$ 


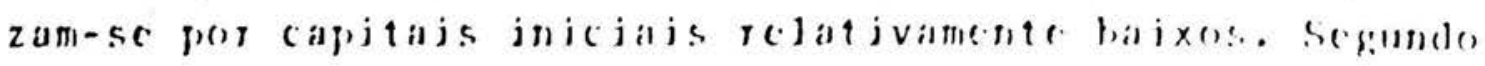
os estudos de ce(ill para o ano de 1974, 6.39 dos cestabedec j mentos dos setores jogados às cantinas cesas de diversões eram classificados como de "nivel médio". Até hoje a situação se mantém. Não localizamos no interior da área de pesquisa estábelecimentos destinados a servir refeições que pudessem ser classificados pela paulistur como de "luxo", a exemplo daqueles que são encontrados na região dos jardins.

Desta forma, o bairro nāo se apresenta muito atrativo como mercado para a força de trabalho. As casas de diversōes, as cantinas e congêneres e o reduzido nū mero de pequenas indústrias se constituem nos setores que mais empregam a população do bairro. A chegada dos nordestinos no mesmo significou um aumento muito grande da oferta de mão-de-obra para estes setores. Segundo depoimentos dos donos de cantinas e daquelas casas de diversōes maior parte da força de trabalho é formada peios mesmos.Es te fato leva-nos a refletir sobre a estrutura econômica que o bairro apresenta e a possibilidade na oferta de empregos que o mesmo pode oferecer. Dá para concluir-se que a grande maioria que procura o bairro como lugar de resi dência tem. que procurar fora do mesmo o emprego. $\AA$ medida que ao trabalhador não é dada a condição de verdadeiramente escolher empregos, mas, ser escolhido, sendo isto mais evidente entre aqueles de baixo nível de qualificação, devemos admitir que um lugar onde as opçōes de emprego não são grandes, a mobilidade espacial da população deve ser grande. Segundo estudos feitos pela SEADE - Sistema Esta dual de Anālise de Dados, a região metropolitana de São Paulo está revelando um movimento de saída da população do 


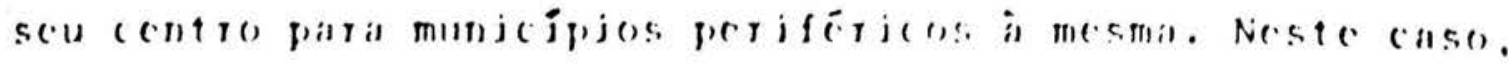
um hajere dense come a pesa Vista deveráser, também, tribu tário desta sajda, o que nos permite pensar numa renevaçäo da sua população.

A renovação da população do bairro, ligada tanto a fatores sócio-económicos como àqueles ligados ao processo de reurbanização, parece-nos algo constante. 0 bairro já viveu momentos onde a grande maioria das pessoas nascia, vivia e morria no mesmo lugar. No caso do Bexiga a presença daquela estrutura de pequenos artesãos permitia is to. A expansão industrial de São Paulo que acabaou representan do no processo de industrialização brasileira sua espinha dor sal, criou enormes desequílibrios entre a cidade e campo e entre uma região e outra do país. Para ampliar a nossa análise podemos invocar a seguinte citação:

"O final da década de cinquenta foi marcado por uma intensa industrialização, uma verdadeira explosão industrial, segundo Francisco de 0liveira. 0 mesmo autor demonstra-nos que a natureza "tardia" desta industrialização forçou um emprego de tecnologia "capital intensivo" nesta década. Foi uma época de contençāo de salārios reais, o que permitiu ganhos espetaculares, permitindo um intenso processo de acumulação de capitais. Segundo Francisco de Oliveira, foi uma época em que a industrialização passou a utilizar uma tec nologia intensiva, absorvendo relativamente uma pequena proporção de força de trabalho , num momento que as cidades passam a crescer em termos demográficos tanto pelo processo do êxado rural como pela taxa de crescimento natural da população urbana. A participação do setor secundário na composição da renda no final da década de cinquenta passou de 318 para 448 , enquanto a força de trabalho 
cmprestada nal mesmal. cont inuon a mesma, aumen tando majs a partio da década de sessenta". (francisco (apuano Scarlato).

A natureza deste tipo de crescimento, que a cconomia brasileira sofreu cstá na base da chegada daquela população de nordestinos para o Bexiga. A medida que aconte cia o processo de reurbanização com todas aquelas implica ções na estrutura fundiária e de ocupação pelos antigos moradores, os nordestinos foram gradativamente ocupando seu espaço. Além destes, que se transformaram nos mais represen tativos, outros, das demais regiōes brasileiras, acabaram chegando também. Este processo de mobilidade da população brasileira tornou-se uma constante até os dias de hoje. Isto acarreta um nível de permanência cada vez menor nos luga res. No caso do Bexiga, à partir do seu "Ano Zero", isto fí cou muito acentuado. Os estudos feitos pela COGEP para o início da década de setenta sobre o tempo de residência dos seus moradores dentro do bairro são muito significativos pa ra nos mostrarem as transformaçōes verificadas no mesmo. Um bairro que sempre havia revelado uma grande estabilidade da população, à partir de então já revelava significativos de mudanças: somente 16,38 da sua população revelaram ter sempre residido no bairro. Com 1 ano de permanência tivemos 108. De lá para cá, o quadro de renovação foi se acentuando. Fato que não foi por nós quantificado, mas que pudemos perceber pelos tipos de depoimentos. Muitos daqueles poucos moradores antigos que ainda vivem no bairro, dizem sentirem se "estranhos no próprio bairro" em função de uma vizinhança que constantemente se renova.

Portanto, o que veio a acontecer ao Bexiga com relação à fixação da sua população é produto da nature- 
zal cetrutural de nosso capitalismo, das contradicóes que c) aprescnta tanto a níves daquelas redações sócio-cconómical c culturilis come nos projetos de intervencōes de reur banjzação e nào algo que tenha sua csscncia no interior do próprio bairro. Fica cada vez mais dificil para o trabalha dor de um modo geral, porém, mais ainda para aqueles de baixa renda poder fixar residencia por muito tempo em algum lugar. Este "nomadismo urbano" que caracteriza a atual relação do trabalhador com relação ao emprego e moradia as sociado à falta de habitação disponível para a classe trabalhadora veio estimulando enormemente aquele apetite dos exploradores imobiliärios. E dentro desta perspectiva que devemos entender entre tantas transformaçōes ocorridas no espaço do Bexiga, uma que the é muito peculiar - a fragmen ção e os grandes desníveis na forma de morar.

Segundo as estatísticas oferecidas pelo setor "Basé de Dados" da PMSP, para um total de 25.634 domícílios com uma média de três pessoas em cada um, a renda média por pessoa no conjunto do universo da pesquisa feita em 1980 era de seis salários mínimos, ou seja 18 sala rios mínimos por domícilios. Sabendo-se que nos últimos anos continuou o processo de contenção dos salários para a classe trabalhadora em geral, podemos concluir que as condiçōes dos moradores do bairro pioraram ou, na melhor das hipōteses, continuaram as mesmas. Desta forma, o Bexiga con tinua sendo um bairro de populaçāo de média para baixa ren da. Isto explica a existência no bairro dos baixos padröes de qualidade de uma parcela significativa de suas habita çōes; poderíamos mesmo dizer da sua quase maioria.

Segundos estudos feitos pela PMSP-Dossie, 054/03 de 1981, era o seguinte o quadro de distribuição 


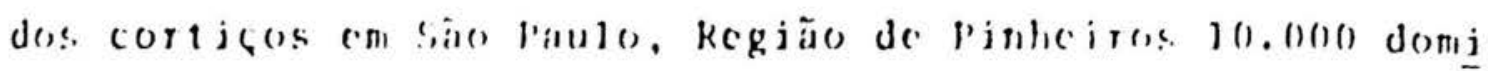
(i)jos emi cortjgos: Sé. Sto. Amaro, lapa, putantá com 20.000 a 30.000. Superior a estes, cstavam, Vja Marja. V j la Pudente e Penha com mais de 50.000. Nesta forma o Bexiga localizado na regional Sé ficava contemplado entre aque les de grande concentração de domicilios em cortiços. Para - setor de Base de Dados da PMSP, o bairro apresentava 2,638 da sua área construída ocupada por residências do baixo padrão e $42,0 \%$ de padrão médio. Acreditamos que aqueles 2,68 correspondam aos cortiços. Não nos foi possivel identificar junto às fontes o que eles classificavam como médio. Porém, pelas observaçōes de campo, acreditamos que a maior parte daquelas cifras referentes ao padrāo médio deverāo conter uma parcela significativa de cortiços. à medida que alguns cortiços do bairro apresentam-se relativamente "conservados".

0 avanço das atividades de serviços e comér cio dentro do bairro não lhe tirou a preponderância da função residencial, porém significou uma mudança na qualidade de vida. 0 aumento das formas de uso misto para os 10 tes do mesmo, significou para a população ter que conviver junto à moradia com uma maior agitação. Estas residências de baixo e médio padrão que constituem, segundo informaçōes da "Base de Dados - PMSP" quase 50 em área construída no bairro encontram-se bem dispersas pelo mesmo. Somente os 10,78 representados por um alto padrão é que estão de uma certa forma mais concentrados, principalmente na região do alto da grota.

0 bairro que sempre se caracterizou pela predominância das habitaçōes horizontais ou seja, aquelas antigas casas, no máximo de dois pisos, viu nos últimos a- 
nes aumentar as construcoecs vertjonis, tanto para residencjas como para outras ativjdades do terciárjo. A funçüo re sidencial do tipe horjzontal, sespundo a fase de lados para 1986 ocupava 5,58 da área construida, enquanto a vertical ocupava 49,9: do total da área construída. Isto signifi cou um grande adensamento na ocupação do solo. Num total de $1.463 .080 \mathrm{~m}^{2}$ de área de terrenos, temos no bairro um tó tal de área construída em $4.471 .341 \mathrm{~m}^{2}$. Podemos observar que, apesar da área construída para residências verticais ser bem maior do que as horizontais, a representação das mesmas em áreas de terreno não difere muito. Para as residencias verticais temos 26,18 do total de terrenos e para as horizontais, 20,98 dos mesmos. Estes números permitemnos perceber o coeficiente de aproveitamento para a região. Para os terrenos ocupados por construções horizontais é de 0,87 e para o outro é de 6,2. Apesar do adensa mento que se verificou nesta região da cidade, muitos polí ticos, administradores e empresários acham que ela comporta um processo maior ainda, visto a grande quantidade de terrenos com baixo coeficiente. Para o total da área da pesquisa da "Base de Dados" o coeficiente de aproveitamento para o bairro é de 3,5 , enquanto o total para o conjunto da regional Sé, na qual está contido, é de 2,3. Fato que comprova o grau de adensamento que o bairro revela no conjunto daqueles que caracterizam o entorno ao centro.Des ta forma, a lei de Zoneamento, crianda em 1972 não foi suficiente para "congelar" seu processo de verticalização. Também para o uso em comércio e serviços, a tendência à verticalização foi muito grande. Hoje, segundo aqulas fontes da Base de Dados, 36,88 do total da ärea construída es tão ocupados por estas atividades em construçōes verticais, 
estande estas mujto concentradas nas bircas proximas aos grandes "corredores" que passam pela regjäo.

$$
\text { Scgundo cstudos fejtos pela lmbracsp (1.m- }
$$

presa Erasiliera de Lstudos do Património), entre fevereiro de 1985 a novembro de 1987 foram lançados no Bela Vista 17 novos edifícios com 1.485 unidades com uma média de $40 \mathrm{~m}^{2}$ cada uma. São apartamentos que em sua maioria se constituem em quarto, sala, cozinha e uma vaga na garagem. Dos 17 lançamentos, somente três eram de dois dormitórios. Paralelamente a estes tipos de apartamentos, vêm aparecendo no bairro construçōes do tipo apartament-hotel e flat. Este fato comprova a afirmação feita pela Sinduscon (Sind cato da Indústria da Construção Civil de Grandes Estrutu ras) de que o "destino do lugar é ser ocupado pelos flats e aqueles pequenos apartamentos Esta instituição não vê pạ ra o bairro a possibilidade de vir a ser ocupado por residências de "alto padrão" a não ser naqueles lugares por nós já assinalados. A expectativa da Sinduscon-sP parece não diferir muito daquela apresentada pelos empresārios nos estudos feitos pela COGEP em 1974. Segundo estes estudos constatou-se o seguinte:

"...Este fato, aliado à falta de definição de uso para a 28-010 classificada como zona especial, justifica o comportamento verificado: as grandes empresas imobiliārias, interessadas nos projetos de maior lucro não se interessam devidamente pela área devido: a) ao grande grau de retalhamento das quadras existentes... b) à falta de uma definição de uso do solo da região que garantisse um salutar interesse da iniciativa privada na ārea, de modo a impedir a sua deterioração gradativa, e mesmo forçá-la a um processo 
de revisial da tendencia...

A constataçäo desse processe de deterioracãa) do preşo de terteno da hela Vista pode ser finalmente verjficado ace se compararem os resultados obtidos cm árcas vizinhas à Bela Vista e em bairros residenciais nobres próximos ao centro da cidade". (PR-016, p. $1-36)$.

Para aqueles projetos que, segundo os estudos, foram classificados de "maior lucro", destinados às camadas de maior renda, o lugar não se apresenta atrativo, a nāo ser em algumas áreas como a do alto da grota, espi gão da Paulista ou adjacências dos grandes corredores para qqueles grandes escritórios. Parece-nos que esta fatia do mercado imobiliārio, até agora, vem sendo explorada pelas companhias construtoras de menor porte que trabalham com uma faixa da população com rendas mais baixas. Estes tipos de construções de pequenos espaços, revelam uma tendência natural para uma clientela com familias pouco numerosas, executivos que trabalham no "velho centro", "Nova Paulista" e aqueles grandes escritórios que estão entrando pelo bairro. Pelo número de novas construçōes observadas durante a coleta de dados e pelos nümeros oferecidos pela Embraesp parece-nos que qualquer risco aos empreendimentos está descartado.

Tudo is to vem colocando os velhos casarões sob a mira das companhias construtoras, grandes ou peque nas. As populaçōes dos cortiços e os antigos moradores cada vez mais ficam sob a pressão desta nova tendência. Assim, o processo de renovação da população tenderá a acen tuar-se mais ainda.

Para Cândido Malta, a proposta que vem sendo elaborada na mudança da Lei de Zoneamento, dentro da 


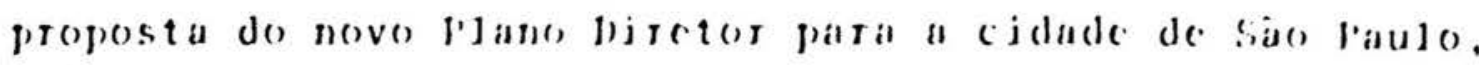
ajnda não aprovado, torna-se uma ameaça para o Hexiga. Se. gundo cle, "o aumento da área construida pela verticaljzação, pode, entre outras conscquéncias significar uma amca̧̧a à existêcia daquelas atividades que caracterizam hoje - lugar - o setor de cantinas e diversões" (Cândido Malta Filho, ex-secretário do Planejamento do Município de São Paulo, Palestra, 31/8/87). Isto nos permite compreender o empenho de algumás lideranças comunitárias do bairrc em se juntar àquele programa contra o Plano Diretor. Desta forma querem defenderse do risco de serem "2liminados" do bairro como foram aqueles moradores da rua Jandaia e Assembléia, juntamente com seus antigos casarões.

A presença significativa dos terrenos ocupa dos pelos casarōes e terrenos vagos, que no local represen tam 14,08 do total da área (Base de Dados - 1986) cria uma grande pressão do grande capital imobiliário sobre o espaço do Bexiga. Estes terrenos que representam uma "reserva do valor imobiliário", cada vez mais se colocam na perspeç tiva de serem vendidas por pressão das grandes companhias e da atual política de planejamento municipal. Os defensores da política de adensamento do bairro argumentam que existe uma infra estrutura "ociosa" neste espaço.

Para Lauro Rios (Ex-secretário da COGEPPMSP, governo Reinaldo de Barros) este argumento não tem sustentação, na medida que se observa que a ociosidade não deve ser entendida somente em relação à infra-estrutura de saneamento básico, mas também, em relação aos equipamentos viários, que para o mesmo, está plenamente saturado. Saturação essa relacionada com uma política de transporte que 
piotjzon o jndividuas. Pejos consecst jonamentos das ruas, pelo intensidade dos fluxos nas suas costreitas ruas c mesmo naquedas que representam as vias expressas, o bexjga não comporta um maior processo de adensamento por verticalizaçāo. Portanto aquela "ociosidade" é falsa. Sobre esta pretensa ociosidade, a posição de Roberto Cerqueira Cesar (Secretário da COGEP-PMSP, governo Figueiredo Ferraz - Palestra - Instituto de Engenharia. São Paulo, Caminhos Possíveis, 27/6/88) é mais enfática:"Não conheço nenhum lugar da cidade que tenha infra-estrutura que permita adensamento".

Por mais critica que sejam as posições dos referidos planejadores e politicos, parece-nos que, apesar de reconhecerem os imediatismos da indústria da construçāo civil eles apresentaram-se impotentes para disciplinar o planejamento do espaço: "Percebi que, para envolver o cidadāo no processo do planejamento, tínhamos que partir do planejamento do bairro. Discutem-se hoje os problemas do adensamento de uma área para conter seu avanço, quando na verdade este adensamento jā encontra-se consolidado" (Candido Malta C. Filho, Secretário do Governo Olavo Setubal Idem palestra anterior) que parece ser o caso do Bexiga. Desta forma por detrās da pol Ética do Estado estão os intê resses representados pelo capital imobiliário e seu crescente papel no processo da Renovação e Reurbanização da cí dade :

"Assim, o espaço vai se produzindo para a-
tender às necessidades de produção e repro-
dução de relações determinadas pelas ativi-
dades produtivas que dependerão do estägio
de desenvolvimento das forças produtivas. A
interrelação entre parcelas diferenciadas
do espaço serão determinadas pela divisão 


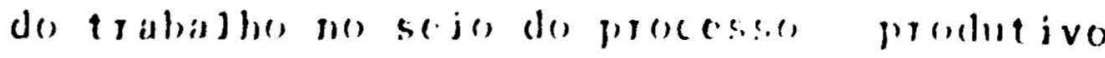
g]obad" (A)essandri liar)os, p. J!s).

Via basc deste processo cestá a questão de como se define a apropriação e diteito de propriedade do solo urbano. Fundamentada no direito da propricdade privada c consequentemente determinada pela diferenciação das classes que nasce da forma de apropriação exercício do direito de propriedade privada, as relaçōes sociais de produção no capitalismo determinam aquelas desigualdades das "parcelas" do espaço - desigualdade na distribuição da quantidade do espaço para cada familia, na qualidade deste espaço expressa num tipo de zoneamento urbano onde a história deixou a marca de uma grande perversidade nascida do privilégio de uma classe sobre outra. Cada vez mais a ameaça de expulsão daquelas populaçōes pobres que habi tam os cortiços são testemunhos desta história.

O Bexiga apresenta-se como um "bairro em transe". Não somente pela maneira como se dá a substitui çāo dos casarōes pelos "espigōes", mas também pela difusão de uma quantidade enorme de novas formas de uso que the caracterizam o espaço. Ele não é somente aquele mundo das cantinas e pizzarias, interiores de casas de shows com música ao vivo ou nāo, "biscateiros" que lutam por um pequeno pedaço de espaço para trabalhar e garantir a sobrevivên cia. Ele é tambēm um espaço de representaçōes que estimula a imaginaçāo - um sentimento de aventura e boemia. No dizer de alguns jovens entrevistados que frequentam 0 bair ro: "Ele é um barato". E um mundo do "exótico". Casas de trocas de objetos usados, antiquārios, comércio de discos usados, artesanato de máscaras decorativas, aluguéis de roupas para espetáculos, artesanato de bijouterias distri- 


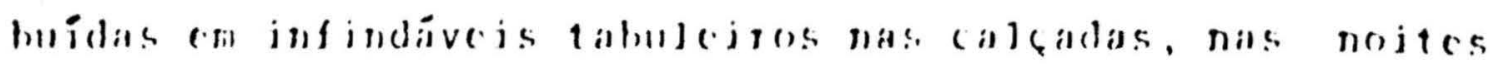
dos finajs de semana. lstá também aś a presença marcante de teatros que cijam un cljma de cescontráäa e mesmo de um "esnobismo intelectual". Teatros pequenos e grandes. In tre os 11 catalogados pela pesquisa, um em especial - teatro Igreja, instalado no interior de um antigo templo religioso, cuja arquitetura foi mantida, acentua-se o "caráter exótico". Este conjunto de teatros acaba criando um espaço de lazer que transcende aos espetáculos oferecidos. Assim, tambēm as 34 casas de música-bar, e os cine-clubes. Tudo isto entra no circuito de consumo, estimulando a "magia" que o Bexiga oferece e que é "industrializada" pela midia.

Grande parte destas casas revelam uma decoraçāo improvisada. Sua clientela, na maior parte, apresentam-se como pessoas "descontraidas". Quando indagadas sobre o tipo de diversão que procuram, revelam-se, na verdade, sem "destino certo". Atraídos pela sua fama, procuram - bairro certos de que, de uma "forma ou de outra", encontrarão alguma forma de lazer e diversão. Desde um bar para uma bebida, até uma casa de espetáculos ou uma casa de dis cos usados. Este espírito é algo presente nas noites do Bexiga. Isto faz do bairro um lugar de encontro de diferen tes camadas sociais. Nele ecnontra-se o lazer desdobrado para todos os bolsos e gostos. Desde um bar de "terceira" categoria, cantinas e pizzarias, àquelas casas de diversōes, ou um teatro encenando alguma peça clássica. A grande quantidade de carros e gente circulando, à noite a procura de alguma forma de "alienação", apōs a semana viví da na tensāo da metrópole, acaba fazendo o bairro parecer uma "grande feira de lazer", um mercado onde se pesquisa 
para se adquiritale "nives de bosso".

Desta forma o bajro acabou consoljdando uma forma de viver na grande metrópole. Na indústria do lazer passou a ser um bairro típico "classe média". Nenhum dos seus estabelecimentos poderiam ser classificados como "cinco estrclas". Quando é procurado pelas camadas mais "aristo cráticas", estas geralmente tem destino certo - teatros ou alguma cantina pela especialidade de seus pratos.

Entre aquelas novas funçōes de um terciārio mais qualificado traduzindo uma tecnologia mais sofisticada, deve-se destacar a presença de empresas de gravações de videos. Estas empresas parecem ter surgido no bairro atraidas pelo espaço cultural que o mesmo apresenta. Ao todo foram registradas sete destas empresas, muitas delas com instalaçōes construídas com esta finalidade. Juntamente com elas têm que destacar-se a presença de quatro empresas liga das ao setor de informātica relacionadas ao processamento de dados.

Alēm destas funçōes arroladas atē aqui, re gistrou-se a presença de muitas insţituiçōes: desde vārios sindicatos, partidos políticos e instituiçōes estatais. Ao todo foram localizadas 23 destas instituiçōes.

Assim, o Bexiga vai gradativamente se transformando. 0 surgimentó daquelas atividades de um terciário mais qualificado tecnicamente; os grandes escritórios, que apesar de não representarem no conjunto uma forma que pela frequência possa ser considerada dominante, estä provocando dentro do bairro o aparecimento de uma mão-de-obra mais qua lificada que aos poucos vai pressionando a qualidade dos demais serviços do mesmo. Com ela surge uma demanda de habita 
cocs mais quajificadas. Tajvez possamos redacionat cste fa to à tendéncia para o aparecimento daquelas construçōes de pequenos apartamentos - flal, apartament-hotel, assim como - surgimento de um número significativo de cantinas, que tradicionalmente só funcionavam à noite, agora estão ofere cendo almoço para "executivos".

A medida que a evolução do processo de urba nização que vem ocorrendo ria metropolização de São Paulo, impelida pelas transformações nas relações sociais de produção, definindo novas especificações e especializações do trabalho, seu espaço vem mudando. Ao mesmo tempo as contra diçōes deste processo vão se revelando de forma mais trans parentes. A presença daquela estrutura fundiária que alimen ta uma forma de especulação e exploração sobre os "velhos imóveis", reproduzindo assim as relaçōes de produção capitalista, criam, também, aquele "obstāculo" para que o gran de capital imobiliário se realize plenamente. Os primeiros reproduzem os cortiços e os "biscateiros", os segundos, os grandes escritórios com aquela população de "colarinhos brancos" e as "novas caixas de morar".

\subsubsection{Em busca de um perfil demogräfico}

Para a Regional Sé, dentro da qual estā situado o bairro da Bela Vista, temos uma densidade urbana das mais altas com 327,74 habitantes por hectare. A Regional do Butantā que registra as mais baixas tem 89,41 habitantes por hectare (Conheça sua Região, Sempla-PMSP,1984). No conjunto da Sé, o Bela Vista é uma das áreas de maior densidade. Para um total de 564.890 habitantes, represen - 
tande os 8 distrjtos em J980, o bairro, com selus 79.61) ha bitantes, respistrava 148 do conjunto, colocando-se como um dos mais numerosos (1B(i), 1980). Esta grande concentraça demegráfica explica-se pelo próprio processo da verticalização como pela įntensificação no crescimento dos cortiços, muito comum nos bairros ao redor do centro da cidade.

Conforme já apontamos em outra parte,

$\circ$ bairro veio revelando uma forte tendência para a renovaçāo da sua população. A entrada de grandes contingentes de imi grantes nacionais que procuraram São Paulo a partir de 1950 contribuiu para estas transformações que ocorreram no perfil da população local. Cada vez mais a população de $i-$ talianos e italo-paulistas foi se transformando em minoria. De um lado pela saída dos mesmos; de outro pela diminuição crescente da entrada de novos contingentes de italianos. Ao mesmo tempo ocorreu o envelhecimento e morte destes anti gos grupos representativos da antiga ocupação. Através do estudo da evolução do processo imigratório para São Paulo, daqueles contingentes de italianos, poderemos concluir que sua expressão para o crescimento da população foi sendo ca da vez mais reduzido, tanto para o conjunto geral da população de São Paulo como para o Bairro do Bexiga. Tomandose por base a evolução da imigração de estrangeiros para o estado de São Paulo entre o período de 1885 a 1961 constatamos que o imigrante que mais entrou foi o italiano. Do total de estrangeiros que entraram no país durante este pe riodo o que significou 2.873 .320 imigrantes, os italianos representavam 1.024 .076 , ou seja: 35,68 , sendo seu periodo de maior intensidade entre 1885 a 190 ? - período em que ocorria o intenso povoamento do Bexiga, época daquele gran de processo de loteamentos, jā referido na primeira parte do trabalho. A partir de 1910 o número de entrada começou 
" declinar. Pura o periudo mais recente, entre $193 !-1959$ en traram somente 90.130 italianos. Os números cairam drastica mente entre 1960 e 1961 , quando entraram para todo o estado de São Paulo 4.144. (Fonte: Imigração Estrangeira e Nacio nal - Comișsão Interestadual da Bacia Paraná-Uruguai. p. 14). Desta forma podemos concluir que o estoque de italia nos existente no bairro foi diminuindo e tendendo a envelhe cer. Pelos depoimentos feitos pudemos perceber que são muito poucos os italianos ainda vivos no bairro. Paralelamente à redução da entrada de italianos ocorreu o aumento significativos de imigrantes nacionais para São Paulo. Para um total de 159.360 estrangeiros de todas as nacionalidades en tre o periodo de 1956 a 1960 tivemos a entrada de 517.624 brasileiros de todas as localidades. Apesar das fontes não trazerem dados estatísticos por unidades da federação, as análises apontam que a maioria deles eram procedentes do Nor deste brasileiro. Relacionando estes dados com o que ocorreu com o bairro - a grande saída de populaçōes com aquelas obras de reurbanização e problemas relacionados com a mobilidade social nointerior da comunidade de italo-paulistas po demos concluir que a representatividade numérica daquela italianidade tendeu a reduzir-se bastante no interior do Bexiga.

Hoje, verificamos uma tendência à diminuição para a entrada de imigrantes nacionais em SãoPaulo: "Na década de 40 a contribuiçāo da imigraçāo para o crescimento total da metrópole era de 728, na década de 1950 era de 598, na década de 60 se manteve em 598 e na década de seten ta cai para 508" (Seade). Conforme análise da autora, grande parte desta imigração ocorreu para o interior da área me tropolitana. Só recentemente é que esta corrente tendeu a 
reverter-se. forem, naguedes periedes anterjeres, os bajtros centrais, com ejes o kexiga, foram contemplaclos com grandes contingentes, principalmente dos nordestinos. As consequências desta imigração para o bairro, como normal mente ocorre nas regiōes que se transformam em pólos de atração, foi o grande crescimento da população de idade considerada ativa.Foi o que ocorreu com o Bexiga. Daquele total de 79.611 habitantes, 70.68 encontravam-se em 1980 entre $18 \mathrm{e}$ 59 anos de idade; dos 0 aos 17 anos, 18 : e acima de 60 anos 10,18 (Fig. 9). Estês nümeros colocam o bairro como um lugar de grande reserva de força de trabalho potencialmente em condições ativas. Pelo que vimos até agora, o bairro parece não absorver todo este pessoal. Poderíamos mesmo afirmar que o bairro, dentro da área metropolitana, funciona como un "bairro dormitório". Sua população em idade ativa parece ai morar mais como uma estratégia para o acesso a empregos nas áreas circunvizinhas.

Observado o número de crianças e adolescente, representando um número de 15.091 de 0-17 anos de idade e comparando estes números com o número de instituiçōes de ensino de primeiro e segundo graus, que ao todo perfa zem 59 salas de aula em duas escolas estaduais e mais duas municipais com 6 salas de aula, a proporção entre pessoas e vagas, torna estas escolas deficitárias em relação ao to tal da demanda. Considerando a população dos 7 aos 17 anos, teremos em média uma relaçāo de uma vaga para 4 pessoas. Não existem creches da rede direta. Existem somente duas da rede indireta com uma capacidade para 300 crianças de 0-6 anos; o que significa uma relação para o bairro de 23 crianças para. cada vaga (Base de Dados).

Seņdo um bairro onde a populaçāo na sua maior parte vive com baixa renda e a infra-estrutura urbana apresenta uma grande precariedade em relaçāo a logradouros pú- 


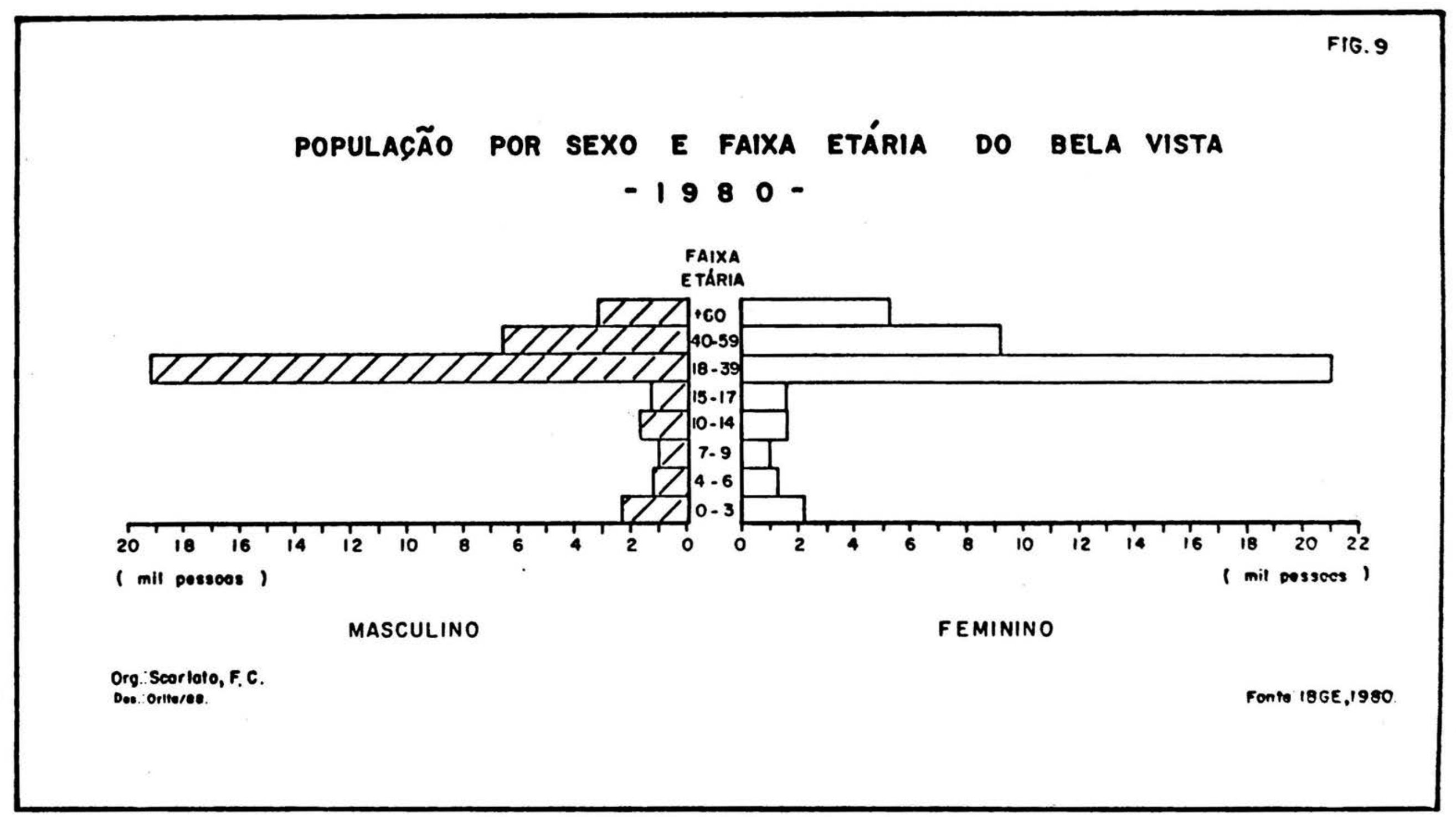




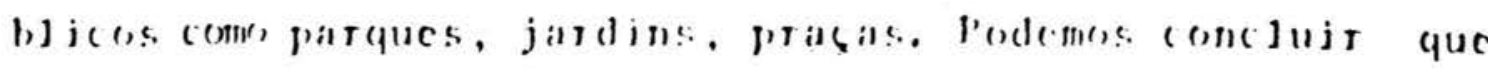
as. criancas das famijas pobres ficam confinadas aos cspa(6) jnterjores dos reduzjos espacos domjejiares daquedes cortiços ou pequenos apartamentos, ou então disputando com os automóveis um pedaço das ruas. Assim, em relação ao ensino o jeito é procurar nos bairros vizinhos vagas para os filhos. Mesmos as classes de maior renda reclamam da preca ricdade das escolas - em número e em qualidade.

A inexistência de logradouros públicos impede que aqueles velhos e aposentados possam desfrutar de um "espaço de ócio". A condição imposta à maioria desta população pela sua condição social impede que os mesmos possam procu ram distante das residencias este desfrute. Cada vez mais - Bexiga divorcia estas duas formas de espaço - ócio e residência. O que sobra para os velhos é o mesmo que aconte ce com as crianças - um pedaço de calçadạ ou um "degrau" das casas com cesso para a rua" que sirva para sentar e apreciar o "movimento". Buscar no confinamento das calçadas, junto ao barulho e à poluição uma "diversão que nada custa". Assim a condição de velho e de criança em um bairro como este passa a ser sinônimo de marginalidade social.

O Bexiga, mais uma vez passa a ser um símbo 10 das contradições do urbanismo capitalista. Quanto mais cresceu a "indústria do lazer" mais a sua população viu-se privada de ingressar neste mercado. Para esta, o que sobrou foi "ver a banda passar". Tão perto dos sonhos vendi dos pelas mídias e tão distante de poderem ingressar no interior daqueles estabelecimentos. O que sobrou foi muito pouco. Das atividades gerais registradas no comércio do bairro, 11,88 são representados por pequenos bares com um 
abeace poucas mesas an redor do mesmo, normanmente usalos pejos "vagantes" que procuram o kexiga, mas que, vez

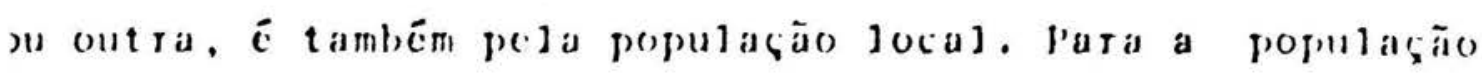
pobre do bairro a possibilidade de "curtir" uma cervejinha E uma das poucas disponiveis para seu bolso.

E. sobre estes pequenos bares que a lideranfa do tradicionalismo do bairro investe com mais severidade. Acham que o bairro deveria sofrer um verdadeiro "expur BO". Referindo-se à "deterioração" ocorrida na paisagem e população do bairro, assim se colocou um daqueles líderes: "O progresso levou os italianos e seus descendentes. Eles, porém têm casas aqui. Eles não querem morar no bairro. Esta deterioração impede que eles voltem. A imigração nordes tina invadiu o nosso bairro... Sobre os nordestinos a maio ria deles residem no bairro tornando-se mão-de-obra para os restaurantes etc. Mas entre eles também existem margi nais. Os Nordestinos não eram como os italianos. Vêm insta lam-se nos cortiços e pensōes, vivem num sub-mundo. A maio ria deles pratica o crime, são marginais traficantes... Já pedimos para a polícia segurança para o bairro. 0 nordestí no como qualquer pessoa é igual a todos. Procuram sobreviver... Querem garantir seu dinheiro e mandar para a fami 1ia... muitos assim fizeram aquelas coisas todas" (Valter Taverna, Presidente da Sodepro, 26/3/88).

Em todos os demais depoimentos - que serão analisados em outro capitulo, verificou-se uma tendência segregacionista em relação aos nordestinos por parte da pô pulação tradicional do bairro. Uma das referências para tal segregação são aqueles bares de encontro, os únicos es tabelecimentos acessiveis aos mesmos. Neles é comum serem 
organizadas "hatucadas" que perpassam ate altas horas da nojte on cntão alguns "forrós" improvisados. F sobre cestas manjestacoes que revelam alguns traços dos novos habjtantes, que se reportam os "defensores das tradições " do Bexiga, alegando que eles vieram tirar o sossego do lugar. O que podemos perceber é que existe naqueles discursos um sentimento de "usurpação" pela chegada dos nordest nos. Na falta de uma transparência do processo histórico que levou a todas aquelas transformaçōes do bairro e conse quentemente à desestruturação da unidade cultural que persistiu até então, tiveram que criar um "bode expiatório"pa ra a impotência frente às determinaçōes impostas pelas novas propostas de renovação urbana para São Paulo no interior da dinâmica de um capitalismo que se "modernizava". 
3.3. A Injade Quebrada

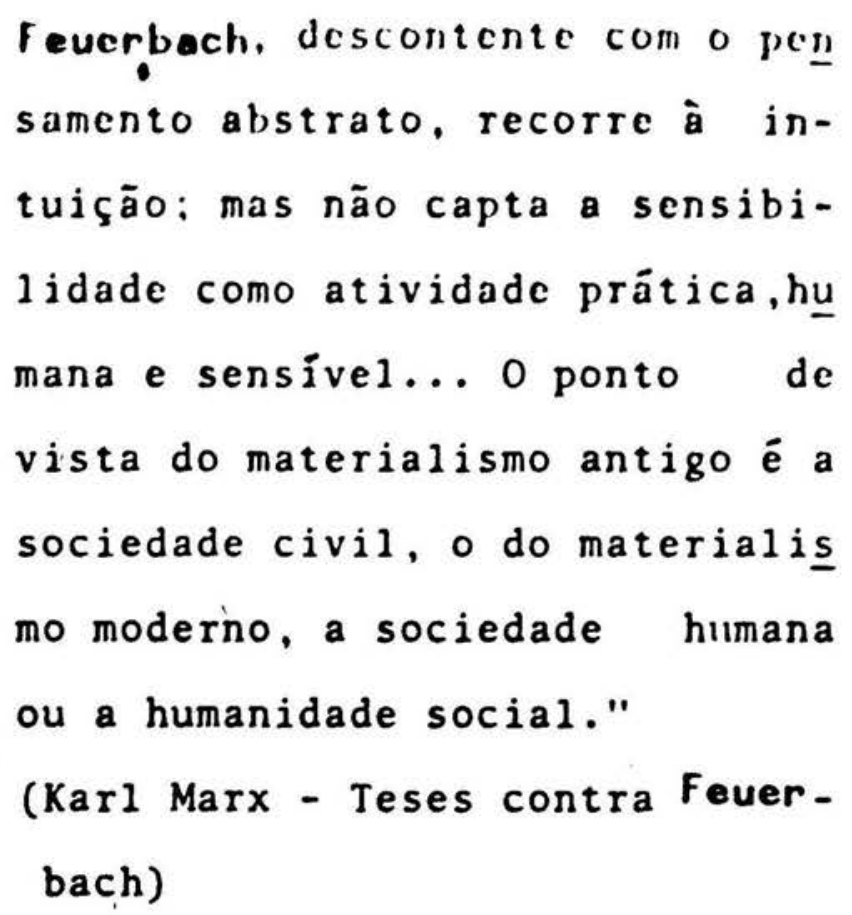

Se até agora procuramos situar o Bexiga como produto de determinaçōes históricas concretas, cabẹ-nos ago a percebê-10 "num nivel mais abstrato", naquele do sensi vel. Nas suas formas e estética espacial.

Ao tratarmos da dimensão estética, definir o belo e feio temos que assumir a subjetividade que o termo envolve, à medida que estas duas categorias encerram mais do que aspectos formais, representam uma dimensão de sensibilidade do homem com as coisas. Para o materialismo histórico o belo representa um produto da atividade prática,histórico-social:

"O belo nasce e desenvolve-se quando o homem social (consoante o grau de conhecimento das leis sociais) desenvolve de maneira mais ple na e livre nas condiçōes históricas dadas,os seus dotes e capacidade criadores, quando im pera sobre os objetos do mundo sensorial quando goza com o trabalho como se se tratas 
se de um jogo das forgas fisjoas e jntedectuais" (Rosental c ludin. p. (2)).

Apesar das dificuldades que nos apresenta este tipo de tratamento tcórico sobre o espaço geográfico, achamos impossivel escapar do mesmo no tratamento do tema da nossa pesquisa. A noçāo do belo e do feio foi uma constante que observamos quando as pessoas, pertencentes ou não ao bairro, referem-se ao mesmo. Tal abordagem é necessária para podermos captar as formas de relações entre as pessoas e as representaçōes que fazem do espaço. Sua forma de sentir e viver com ele. A noção de feio e belo perpassa constantemente o nosso cotidiano. E uma das referências que nos remetem aos lugares.

Nossa condição sōcio-econômica determina o nível de consumo que fazemos do espaço - a residência o transporte, as formas de lazer. As necessidades econômicas e nossa condição de classe circunscreve-nos ao mundo das necessidades, delas emerge nosso sentido estético do mundo. Nossas experiências com este mundo acabam definindo os pa drōes do belo e do feio. Se a verdadeira liberdade reside na capacidade do ser social em superar os limites que as necessidades impõem ao ser humano, consequentemente esta superaçāo leva-nos dialeticamente a uma redefinição contínua daqueles padrōes estéticos. Porém, às vezes isto acaba nāo acontecendo. Sobre este fato, a posição de J. Teixeira Coelho Netto é a seguinte:

"As normas de como se faz arquitetura, espe cialmente, de como fazer o belo em arquitetura, perfazem um código rígido ou no mäximo, vārios cōdigos rígidos... E sāo tāo for malizados que não é difícil atribuir à ar- 
quitetura a etjqueta de arte mais conservadora c mesmo majs retrógrada e reacionátia (no sentido especifjco que se opoce a uma aৎão) dentre todas outras... Zevi, por exemplo, não hesita muito em dizer que quase to da a arquitetura ocidental depois do século XVI é uma arquitetura renascentista - e. sendo justo, nāo é exagéro algum defender tal posição" (Coelho Netto, p. 131).

Neste sentido, para compreendermos aquelas propostas de renovação urbana que foram feitas para o Bex ga, as interpretaçōes que foram feitas sobre este espaço das quais emergiram as formas de reurbanização, teremos que pensar que, sem esta abordagem, não chegaremos a perce ber os desencontros que se verificaram nas mesmas. Implíci ta ou explicitamente o insucesso daquelas resultou, além de fatores politicos e ideológicos que nortearam sua elabo ração, de uma posição que parece não ter levado em conside raçāo, de forma mais objetiva, o Bexiga enquanto uma deter minação histórica concreta. Parece-nos que aqueles proje tos levaram em consideração uma concepção de cidade "monumento" e não como lugar de morada humana. Ainda hoje, qua $\underline{1}$ quer crítica que envolva a estética do espaço urbanistico, está presa aos padrōes clássicos renascentistas de ritmo, medida, harmonia e composição. E neste sentido que o referido autor vê a arquitetura e o urbanismo. Reagir a este classicismo não significa abandonar aqueles quatro elementos bảsicos na anālise estética, porém, devęse propor uma nova dialética entre os mesmos. Propor uma nova ação e uma nova leitura para o espaço, onde harmonia e ritmo obrigato riamente não significam o continuísmo estético e o "equilí brio geométrico absoluto" e a composição como "unidade íntegra e perfeita", não mais procurando-se as soluçōes esté 
tjoas utravés dos "blocos monoliticos c fachadas".

lojocat em jogo a noşäo de bejo c fejo num momento que procuramos analjsar c compreender o espaço geo gráfico, é procurar cercar o mesmo enquanto uma realjdade totalizante: Se o homem se liberta quando é capaz de romper com a limitação da escasses, esta liberdade passa pela capacidade do mesmo em criar um espaço na quantidade e qua lidade condizentes com sua condição humana. Quando for capaz de sentir este espaço como algo integrado, como sua parte integrante, onde, homem, obra e natureza formem um todo integrado e harmonioso em um movimento contínuo em busca do belo. Se o plano da satisfação das necessidades materiais satisfaz o corpo, o belo satisfaz o espirito humano. Assim, a estética deve ser entendida como a dimensão da ação e do sensível na busca daquela integração. Qualquer proposta de intervenção no espaço como instância da dimensão humana deverả levā-la em consideração.

Ao geógrafo cabe também partir para este ní vel de compreensão do mundo. Fazer ciência não significa amputar a realidade. Se a Geografia Crítica libertou a Geo grafia do "determinismo da paisagem", devemos agora libertar o geógrafo do modo de compreender o mundo sob a ótica da estética. Isto não significa recuar mecanicamente a Humboldt - tão mal compreendido por aqueles que partiram para a crítica da chamada "Geografia Tradicional", mas pro curar resgatar muitos dos ensinamentos contidos em sua obra. A força do pensamento de Marx residiu na tenacidade como procurou negar Hegel e não em ignorā-10. Aquele humanismo contido no pensamento de Humboldt, abortados por um pretenso cientificismo, deve ser resgatado pela Geografia Critica enquanto proposta de uma Geografia libertadora. 
Assim, Jevemos partir piral o cestudo do espargo do Bexiga. Procutat vet o nivel de integragáa que se de finiu cntre os diferentes componentes deste espaço. Isto nos levará a captar os vicses entre a estética c a idcologia, tema de grande importância para a comprecnsão da instância do imaginário. A avaliação que scus tradicionais habitantes fazem do seu espaço perpassa por esta subjetividade. Dificilmente eles têm uma visão integrada do processo histórico que determinou aquela realidade. Daí, termos que procurar no nivel do discurso dos mesmos, as relações entre - que é objetivo e subjetivo na explicação que fazem daquele espaço. Tentar perceber em qual momento este nível de subjetividade tira-os do nível do real para lançá-los no mundo do imaginário. E quando poderemos compreender os cami nhos percorridos para a criação de muitas mistificações criadas por eles e por outros sobre o Bexiga.

O Bexiga é produto de formas de existências sociais que deixaram suas marcas no nível da aparência que cerca a esfera material e plástica do bairro. Neste nível de análise encontraremos fortes testemunhos que marcam aque 1a época. Através do confronto dos mesmos poderemos perce ber os encontros e desencontros dos seus habitantes com 0 produto plástico que a história escreveu sobre este espaço. Entre os componentes mais importantes deste conjunto devemos destacar as casas, ruas e quarteirões não como componen tes isoladamente, mas de forma dialética. Uma dialética que tem no seu interior o habitante enquanto um ser historica mente determinado e não como mero elemento presente na paisagem. E preciso encontrar nas casas e nas ruas as evidên cias plásticas desta determinação. 
Sabemes que a cassi chquanto bugat de abrjgo, E majs do que uma soluçào técnica para que o homem se reproduza como set c forga de trabalhe. lisa $\bar{c}$, cm última instância, o lugar que the permite um encontro consigo mesmo. A moradia vista enquanto um espaço "interior" daquele con junto, representa para o habitante seu abrigo e refúgio.porém, sabemos que entre o interior da moradia e seu "exterior" - a rua, o bairro a cidade etc. não existem limites absolutos, pelo contrário, relativizam-se formando uma tota lidade dialética. O exterior é também parte de um interior na medida que é nele que o homem urbano define-se enquanto um ser social e politico - um ser concretamente urbano. 0 isolamento no seu espaço interior, a moradia, o abrigo, refúgio, ao invés de anular, confirma aquele espaço exterior, à medida que este isolamente, que a moradia lhe permite, existe como resposta a um estímulo de uma exterioridade urba na, Portanto o homem vive uma totalidade onde, interior $e$ exterior, coletivo e privado estão em relaçōes dialéticas.

Casa e rua representam o lugar de moradia do homem urbano: expressão de sua natureza orgânica e racional. A produção da casa e da rua é a resposta às necessidades fí sicas e psicológicas do homem, colocando-se como um compo nente orgânico de sua racionalidade, à medida que revela so luçōes formais para seus problemas. Nas cidades, espaços in teriores e exteriores, encontram-se profundamente relativizados e qualquer abordagem que queira absolutizar algum deles poderá levar à perda da transparência histórica do fenô meno urbano.

0 modo de produção capitalista na sua evolu çāo foi criando cidades gigantescas e definindo formas espe cificas de convívio social. Por onde o capitalismo foi conso- 


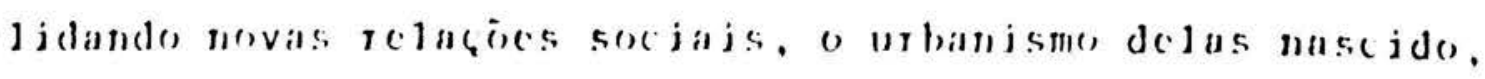
foj sjgnjficando novas concepcócs de produçäo do espaço ut bano:

"Mas a verdadeira redenção do século XIX realiza-se nos espaços exteriores, isto é na urbanistica. Portanto os grandes fenômenos que se seguem à Revolução Industrial e principalmente o urbanismo e o advento dos novos níveis de locomoção o século XIX defronta-se com os problemas do espaço citadi no, irrompe para além dos muros antigos, cria nos bairros periféricos, formula os temas sociais da urbanistica, no sentido mo derno da palabra e constrói a cidade jardim... A exigência social que jā não pōe à arquitetura temas áulicos e monumentais, mas - problema da casa para a família média, da habitação para o operário e camponês até agora fracionada em pequenos e sufocantes cu bos justapostos, e a nova técnica construtí va do aço e cimento armado, que dá a possibilidade de concentrar os elementos de resistência estática num finissimo esqueleto estrutural, concretizam as condições exis tentes para a teoria da "planta livre" (Bru no Zevi, p. 88).

Se a "planta livre" desenvolveu uma nova concepção de liberdade criadora para o arquiteto projetar os espaços "interiores" da residência, o mesmo não podemos pensar para o conjunto do urbanismo como sintese daqueles "interiores" e "exteriores". Parece-nos que o sistema ao se desenvolver foi divorciando estes dois tipos de espacia lidade, transformando cada vez mais a residência em lugar de confinamento no conjunto da cidade, que em muitos casos foi sendo sinônimo de cárcere. Quanto a isto, Bruno Zevi nos faz a seguinte colocação: 
"lor centenas de mijonjos a comunjade pajeopolitjca ignora a geometria. Mas assim que se cstabjlizam as hases do neolitico,e os caçadores - criadores são sujcitos a um chefe de tribo, surge o tabuleiro de xadrez. Todos os absolutismos políticos geometrizam organizam o cenário urbano com eixos e de pois outros eixos paralelos e ortogonais.To das as casernas, as prisões as instalaçōes militares são rigidamente geométricas. Não é permitido a um cidadão virar à direita ou à esquerda com um movimento orgânico, seguindo uma curva: deve girar a 90 graus, co mo uma marionete" (Bruno Zevi).

E neste sentido que invocamos o sentido a estética no estudo do espaço. Na capacidade de resposta que a produção do mesmo possa vir a dar ao homem enquanto agente ativo e passivo do mesmo, onde as formas devem harmonizar-se.

O bairro do Bexiga é a prova de como naquela evolução dialética do capitalismo foi capaz de escrever no espaço as suas contradiçōes. Este espaço que jä foi a expressāo de uma forma criativa de busca de liberdade é ho je a expressão do "trāgico". Não que o mesmo não guardasse no seu interior contradiçōes e desajustamentos entre aqueles componentes. Porém a escala em que os mesmos se coloca vam ainda permitia pensar em soluções dentro daquela criatividade que nascia da liberdade do indivíduo com sua comu nidade.

0 imigrante impelido pela vontade de aqui ficar, forjou suas raízes no bairro da forma mais sólida que o sistema ensina - a propriedade privada. Alinhavando casa por casa ao longo daqueles lotes, o imigrante foi re- 
vedande desde o fim do siculo passado sua criatividade arqujtetonjca para superar as limitacoós que a escassez destes pequenos jotes impunha á construção da moradia. Aque. las casas baixas de frentes cstreitas, foram por muitos anos a paisagem dominante do bairro. Representaram um espaço de vivência onde o nível de integração revelava formas de vivência organicamente estruturadas. Neste contexto é que aparece um dos símbolos criados sobre a italianidade do Bexiga, que muitos ainda tentam reproduzir através de algumas montagens fotográficas do atual bairro - a "cadeira na calçada". Esta era mais do que um lazer, era a ex pressão de uma forma de integração do seu usuário com o es paço - sentinelas da casa e da rua como sua obra e da comu nidade. A sombra dos grandes edifícios ainda nāo havia ca do sobre o bairro. As casas guardavam uma escala humana no conjunto do espaço edificado. 0 espaço ainda não havia sido "mutilado" pelas investidas da verticalização. Espaços in teriores e exteriores guardavam aquela harmonia. Apesar de ter sido em grande parte estruturado em forma de tabuleiro de xadrez sobre um terreno colinoso, as ruas do bairro guardavam a possibilidade de integração, visto a plasticidade e diversidade das fachadas das casas ao longo daque las ruas. Mesmo formando uma massa compacta de casas, sem recuos lateriais ou ao alinhamento da rua, a pouca altura permitia que o conjunto do casario não se impusesse de forma massacrante sobre seus habitantes. Ao mesmo tempo,as fortes relações de vizinhanças permitiam a integração do homem com sua paisagem. A rua era a praça. Em qualquer rua que se percorresse a paisagem se repetia. A única diversidade que se observava residia na diversidade naquelas fachadas onde cada um dos habitantes procuravam deixar seu. 
ioque de originalidade. O produto no conjunto formava uma grande harmonia, um todo organico, mantendo aquela cescaja humana no conjunto do espaço. Era uma diversjade que integrava. A suavidade das colinas do sitio urbano do Rexiga, por muito tempo pode ser reconhecida na medida que aquele "fino tecido construido", ajustava-se de forma harmoniosa ao relevo, apresentando uma composição, sociedade e natureza de bela plasticidade. Raramente este conjunto era quebrado. A regiāo da grota representava uma das poucas áreas de contraste no conjunto desta paisagem.

Bairro desprovido de praças e de verde, que na verdade não fizeram muita falta para seus moradores até algumas décadas atrās. Os grandes pomares dos fundos de quintais compensavam a pobreza ou ausência de arborização natural dos espaços públicos. Podia-se viver no Bexiga as comodidades da vida urbana e ao mesmo tempo cultivar algu mas formas de vida "rural". Casas e pomares eram também lugares de convívio para parentes e vizinhos. Não rara eram as festas de convivio realizadas nestes espaços naturais.Enormes caramanchōes formados por videiras eram comuns nestes fundos de quintais onde as familias e amigos se reuniam Mais tarde quando os pomares desapareceram es automóveis invadiram as ruas é que o Bexiga revelou-se como um espaço pobre em logradouros públicos para sua população.

O Bexiga viveu, durante seu período de "rua comunitária", quando ainda o automóvel não havia entrado pa ra comprimir as calçadas e expulsar seus moradores, aqueles antigos sentinelas, a experiência de uma fase em que o público e o privado conseguiam formar dois mundos não exclu dentes. Entre a casa e a rua existia aquela integraçāo cada uma se abria para a outra. Podemos dizer que se vivia o Bexiga e nāo no Bexiga. 
Aqueda grande quantjade de artesãos - casa c rua, cncertavim em si uma forma de existencia. No mesmo tem po que a casa cra o lugat de abrigo era também o Jugar onde sc produziam as condiçōes materiais de existência. Costurava-se com as janelas e portas abertas para a rua. A rua estava dentro do seu ateliê. A passagem das pessoas eram imagens que se incorporavam às atividades de trabalho que se realizavam no interior da "casa-oficina". Assim, também ocorria com as sapatarias, marcenarias etc.

Toda esta forma de viver o espaço no Bexiga permitia uma existência com o espaço para o indivíduo como um ser por inteiro. Ainda era possível para este "pequeno burguês" sonhar com a "liberdade" da pequena iniciativa empresarial, quando ainda o "pequeno modo de produção" não havia sido desestruturado pelo ingresso do capitalismo monopo lista com o intenso processo de metropolização de São Paulo. A criatividade do artesão e seu "paternalismo" com relação ao "aprendiz" ou mesmo com o assalariado, criava uma atmosfera que camuflava as contradiçōes existentes nestas rela ções. Poderíamos dizer que se vivia uma atmosfera "romântica" no bairro. As próprias diferenças étnicas entre italianos e negros, sendo estes últimos também bastante numerosos, não criavam formas "aparentes" de segregação. 0 convívio era revestido de paternalismo daqueles sobre os outros.

Um mundo de cordialidades ainda era possivel neste bairro. Cordialidade do tipo "pequeno burguês ". Acima de tudo procurava-se preservar a liberdade individual. 0 espírito de comunidade nascia da preocupação de se preser var a mesma. Recebia-se e visitava-se a vizinhança, porém sempre acompanhado de um ritual determinado pela natureza do "contrato social", onde a privacidade era sacramentada. 
1)ai, tadvez comprecndermes a importancja que os espasos ex teriores como a rua, represcntavam para aqueda convivencia, criando, assim, a própria essencia da comunidade. A privacidade da moradia não significava isolamento, mas dialeticamente a afirmação daquela. O compartilhar dos caramanchões não era uma "devassa", mas um consentimento a ser re tribuido. Isto também nos ajuda a compreender a diferença entre o cortiço como forma de habitação daquela época com a de hoje. Podemos pensar que aquela vida comunitária do Bexiga com suas fortes relaçōes de vizinhança era a afirma ção de uma individualidade, daqueles "micro-cosmos familia res", juntamente com aqueles casarios alinhados lado a lado, onde casa e oficina criavam uma totalidade dialética do individual e do coletivo. Diferentemente daqueles bairros aristocráticos, o espaço do Bexiga apresentava-se como uma massa compacta de edificaçōes. Porém, onde a proximida de física significava também a social.

Homem, casa e rua harmonizavam-se. Para Bachelard estes espaços assumem a seguinte dimensão:

"O geógrafo, o etnōgrafo podem descrever bem os tipos mais variados de habitação.Sob esta variedade o fenomenólogo faz o esforço preciso para compreender o germe da felicidade central, seguro e imediato. Encontrar a concha inicial em toda a moradia, mesmo no castelo, eis a tarefa primeira do fenome nólogo... Pois a casa é nosso canto do mundo... e se a casa se complica um pouco, se tem porão e sótão, cantos e corredores, nos sas lembranças têm rẹúgios cada vez mais bem caracterizados... Em seus mil alvéolos, - espaço retém o tempo comprimido. 0 espaço serve para isso" (Bachelard, p. 192-202). 
para lefebve, a cjade define-se como sendo a "projeção da socjedade sobtc um local", ao quas nos acrescentamos, um espaco edjficado onde a continuidade c descontinuidade das formas revelam o próprio movimento dialético da História.

Transpondo o pensamento de Bachelard para o estudo do Bexiga, podemos dizer que a atual configuração que este espaço guarda hoje, é o tempo comprimido pela tra jetória que o capitalismo escreveu neste espaço. Para Lefebvre aquela dimensão fica assim determinada:

"Sim, lê-se a cidade porque ela se escreve, porque ela foi escrita. Entretanto não basta examinar este texto sem recorrer ao contexto. Escrever sobre esta escrita ou sobre essa linguagem, elaborar a metalinguagem da cidade não é conhecer a cidade e o urbano. 0 contexto, aquilo que está sob o texto a ser decifrado, a vida cotidiana, as relações imediatas, o inconsciente do "urbano", aquilo que não se diz mas que se escreve me nos ainda, aquilo que se esconde nos espa ços habitados": (Lefebvre, p. 155).

Assim, estes dois grandes pensadores, permitem-nos mais uma vez repensar a validade da nossa preocu pação em tentar, na evolução do espaço do Bexiga, nunca perder de meta a dimensão subjetiva do mesmo. Tentar captar o movimento da história, pelo qual passou, não somente como algo materialmente escrito sobre o território, mas também no nível das representações.

Aquele período por nós chamado de "Ano Zero" significou o momento da ruptura. O Bexiga passou a mudar em sua paisagem e em sua forma de viver. Apesar das formas embrionárias da indústria da construção civil. o 
bajro havia guardacle ate os anos cinglienta grande parte da sua antiga fisjonomia. Npesar dos conjuntos de casas geminadas majs modernas que foram construidas enere 0 : anos trinta e quarenta cos pequenos prédios de três andares, te rem representado uma forma de quebra naquela continuidade paisagística, elc, ainda, mantinha uma unidade espaço-tempo ral, permanecia dentro daquela escala humana na sua paisa gem.

Quando as investidas da construção civil começaram a esboçar-se a partir da década de cinquenta, o bairro começou a se ver ameaçado pela verticalização. o que nos leva a tomar este período como o início deste processo foi o surgimento da Lei $n^{\circ} 4.124$ de $14 / 11 / 51$ que dispunha sobre as construções nas ruas dos Ingleses e 13 de Maio com a finalidade de se impedir a construção de prédios nestas ruas para a preservação da paisagem de quem morava no Morro dos Ingleses. Segundo dépoimento de um ex-secretário do pla nejamento da PMSP, esta lei de 1951 foi quase uma imposição da aristocracia que morava nos palacetes ai localizados,para nāo perder a "Bela Vista" que se descortinava do lugar, tendo a cidade em toda sua amplitude como paisagem. Esta po de ser considerada a "primeira grande lei de zoneamento"que o bairro presenciou.

A grande mudança efetivamente ocorreu quando a indústria da construção civil, estimulada pelo novo siste ma Financeiro da Habitaçāo (SFH) como instrumento para o processo da cumulaçāo capitalista, entrou no bairro e na cí dade. A partir de entāo os recursos financeiros gerenciados pela instituição através do BNH, além de financiar a indústria da construçāo civil, a construçāo de prédios de aparta 
nt: tima. ion também a construçao de obras públicas para me harsa. ... cquipamentos urbanos - veja-se o programa Cu iste aco ou mesmo a sua revelia, transformando-se em um ist-umer. llis şāe de teferido programa feitos pela Fundação Faria Li 1-UERA:. a z zhou-se concluindo que se fazia necessário conHolet tais ffeitos.

Foi quando o bairro presenciou sua "demoli To para daz- lugar às vias expressas que hoje o cortam. A enezraçāo zue se foi verificando de prédios de apartamen ps marcou =ois momentos diferentes. Um primeiro que foi tentativa de entrada de apartamentos para uma classe - maior reda. Isto pode ser ainda comprovado pela presena, na rua jacareí e Maria Paula de grandes edifícios com aćōes de =onstrução para aquele tipo de segmento social. a svenida kove de Julho e imediações da rua Rocha, também fossível perceber-se aquela tendência, abortada na parte pebre" do sairro, mas continuada na área do espigão e alto la grota. =quanto os edifícios de alto padrão migraram pala aquelas partes mais nobres, o interior do bairro passou 1 eepreser:=Er o segundo momento - o da entrada de apartamen tc para um população de menor renda. Aquelas ruas tradicio hais passa =am a derrubar suas casas e dar lugar para confihajos préc- os de apartamentos. Os mesmos foram construídos bem play-z= cund, garagens e recúos e quando possuiam áreas le serviç = estas sé apresentavam bem pequenas. Os contras tes nas es=alas começaram a ser discrepantes. Prédios com $k$ zandes gezaritos ao lado de forma comprimida, sem qualquer recuo com ss antigos casarōes. Mesmo entre os prédios a diferença dze gabaritos criava uma falta de unidade. Não que os mesmos jevessem seguir um "continuismo estético", porém 
" que se observava era uma "estonteante" quebra de unidade. A jém de significar uma "estranha forma de morar" dentro do bairro, uma forma "promiscua", para mujtos significava tam bém a entrada do "forasteiro".

A deterioração das construções não se restringiu somente aos cortiços nos casarões. A maioria daque les edifícios que foram sendó construidos, também foram atingidos. Famílias numerosas e "ação entre amigos" - pessoas que juntavam as rendas para poderem alugar um apartamento - passsaram a significar um adensamento destes espa ços. Salas que viraram quartos, janelas e terraços frontei riços que se transformaram em varais de secar roupa, e mui to mais. 0 "encortiçamento" acabou se estendendo àqueles novos prédios. Cada vez mais se presenciava a queda dos serviços de conservação material destes edifícios. O Bexí ga tornou-se um lugar onde o espaço passou de forma continua a sofrer o fenômeno da fragmentação, surgindo, assim, aquele elevado número de domicílios apontados anteriormente. Funçōes residenciais disputafam palmo a palmo aqueles espaços, com valores por $\mathrm{m}^{2}$, cada vez mais caros. 0 acesso ao bairro somente era possível pela fragmentação contínua das unidades de espaço entre vários usuários para um mesmo lote. Assim, estimulou-se a sub-alocação. Para aqueles pe quenos negociantes do "terciārio informal" era a única pos sibilidade de arcar com 0 aluguel para 0 empreendimento que, por sua vez, nem sempre demandava grandes espaços.

o Bexiga é hoje o lugar de encontros e desencontros, do arcaíco e do novo. Lugar de sobrevivência de antigos e tradicionais morädores que cada vez mais se constituem numa "população marginal" pela perda contínua de sua identidade, ao mesino tempo que é o lugar do "foras- 


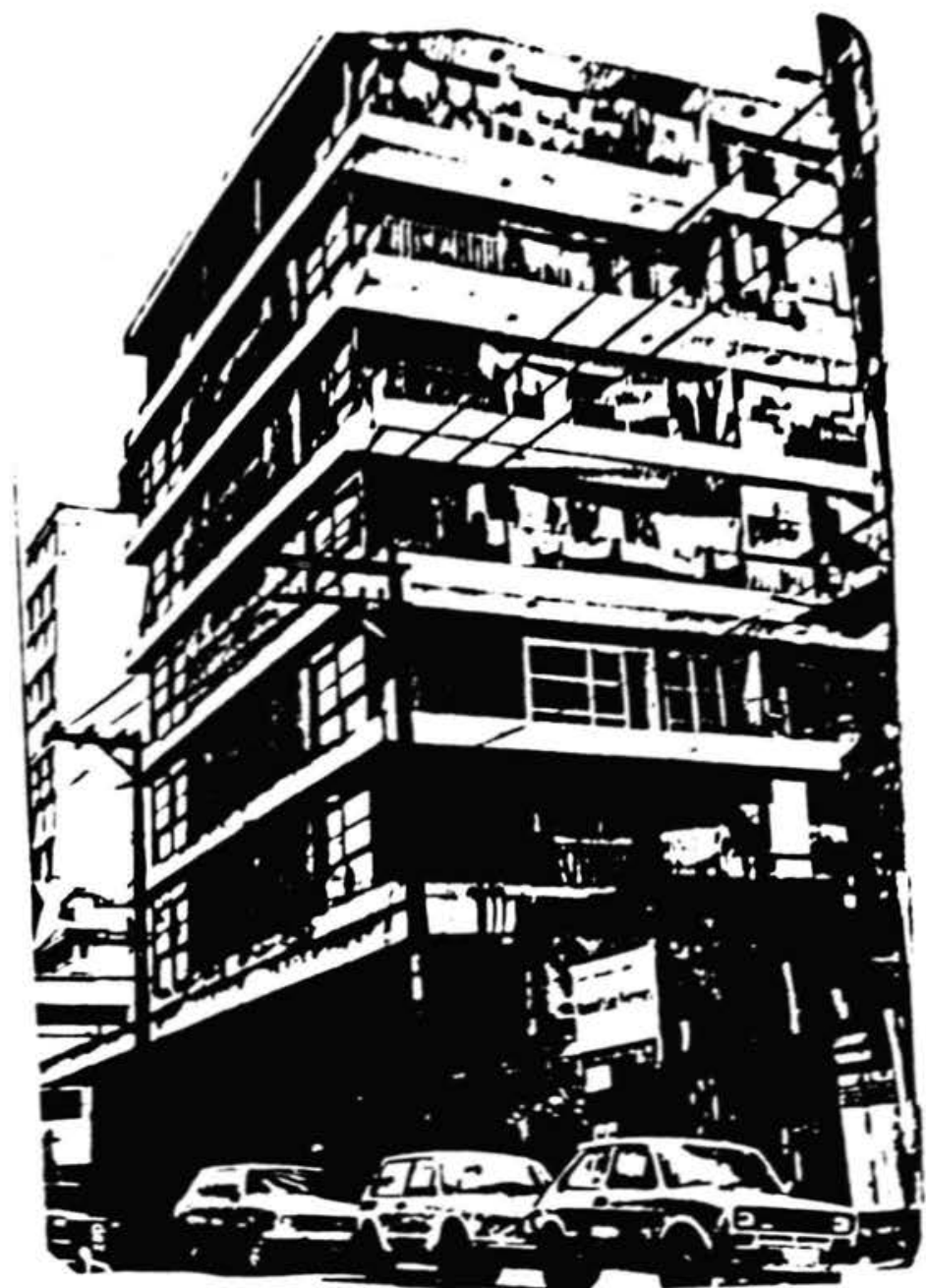

Foto 8: Edifícic localizado na rua Major Diogo. Data aproximada da década de 60. Observe-se a descaracterização na sua forma de uso. (Ano: 1988)

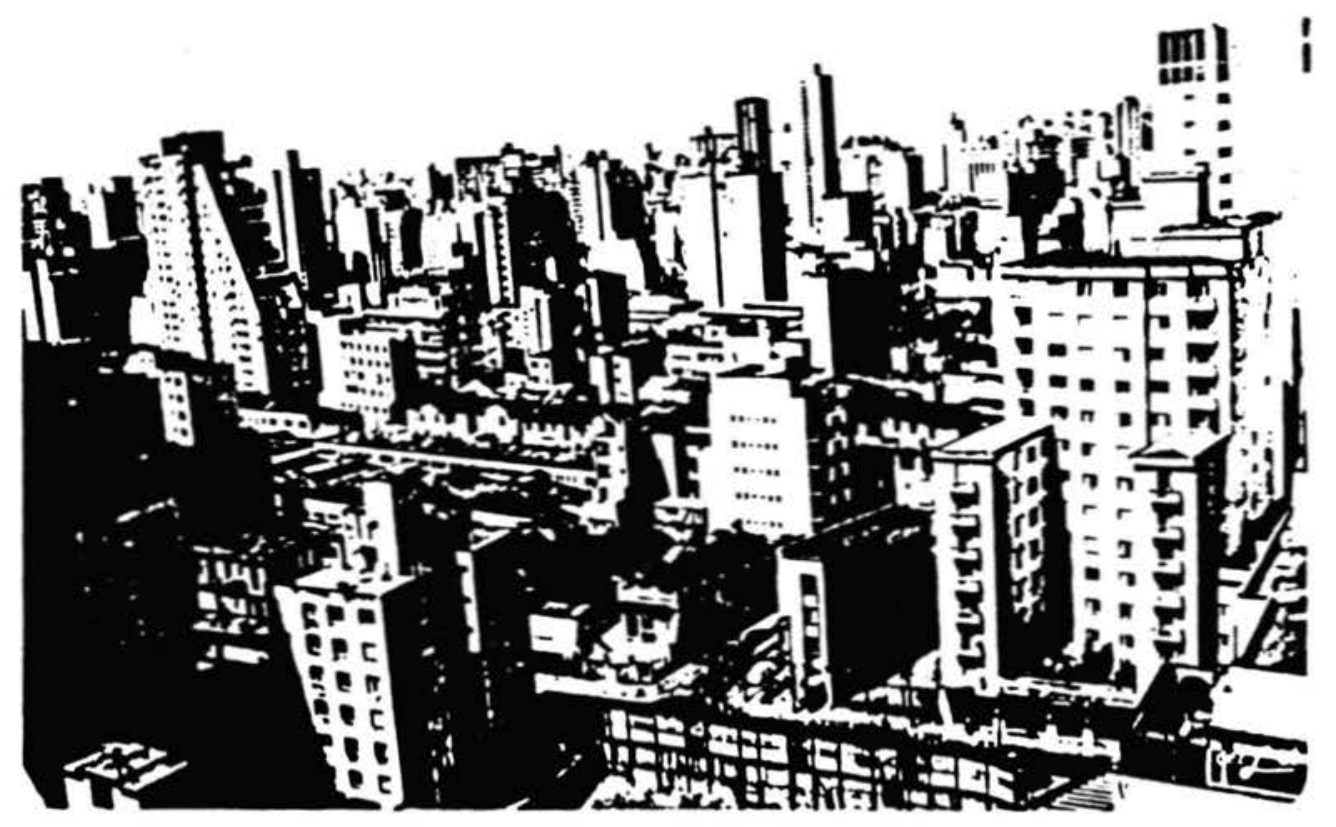

Foto 9: Regiāo do Bexiga localizada no ângulo formado pela Rua Maria Paula e Av. Brigadeiro Luiz Antonio. Area onde o adensamento foi muito grande. (Ano: 1988) 
teito" que neje procura o "refúgjo" on o "dermitórjo" mais próximo do trabajho.

Lembrando kachelard:

"A casa é um corpo de imagens que dão ao homem razōes ou ilusōes de estabilidade... A verticalidade é assegurada pela polaridade do porão e do sótão... Com efeito quase sem comentário, pode-se opor a racionalidade do telhado à irracionalidade do porão... Todos os pensamentos que se ligam ao telhado são claros. No sotão, vê-se com prazer, forte o satura dos vigamentos... Para o porão também encontramos, sem dúvida, utilidade. Nós o ra cionalizaremos enllmerando suas comodidades. Mas ele é em primeiro lugar o ser obscuro da casa, o ser que participa das potências subterrāneas..." (Bachelàrd, p. 208-9).

Procurando estabelecer um paralelismo entre - pensamento do autor com omsso espçao, sentimo-nos livres para ver certas semelhanças entre as partes do espaço da casa com a cidade. Quem nāo sente a força do grande capital através dos seus grandes monumentos - Shopping-Centers, ed fícios monumentais dos grandes bancos. Em lugar dos bairros "abertos" para a cidade, os grandes condomínios fechados. Em lugar dos escritórios no "centro" da cidade, as mini-cidades tipo "fortalezas" como os centros empresariais a exem plo do St. Amaro ao longo da marginal do Rio Pinheiros. A racionalidade dos grandes espaços estruturados com a beleza e o conforto das grandes estruturas. A plasticidade do concreto armado e do aço forjando estes monumentos ao capital. Expressão da classe dominante. Em contra partida, aquele espaço da escarniçada luta pelos metros quadrados dos cortí ços e portas de garagens onde se instalam aqueles "pequenos 
negociantes" c biscutejros.

- Sim, o Bexiga é lugar das "poténcias subterráncas". Sub-alocadores exploram o mercado de alugraeis dc forma execrável sobre uma classe trabalhadora de bajxa renda, esperando-se umá valorização do terreno. Como "porão" da cidade que cresce, representa a indefinição, o obs curo, o lugar que aguarda uma definiçāo do grande capital, que aos poucos vai definindo seu contorno. A luta pela de $\underline{r}$ rubada da Lei de Zoneamento e Uso Especial do solo, a expulsão daquela população de baixa renda parece-nos questão de tempo. E só lembrar o destino dos casarōes da rua Jandaia e Assem bléia, sobre os quais pessoas e instituiçōes como DPHPMSP procuravam lançar movimentos de defesa; porém, como eram minoria e "fracos", o poder executivo exerceu seu poder e mandou sumariamente derrubā-1os para estabelecer "obras de paisagismo" com objetivos questionáveis. Parece-nos que nesta história toda acaba prevalecendo. a racionalidade do poder das classes que dominam. Assim como aquelas duas ruas, tom bou, também, a vila São José do Bexiga, valioso testemunho das tradições do Bexiga.

o bairro hoje é um novo espaço. Não foi somente a paisagem que mudou. As relaçōes entre as pessoas são outras. Os, antigos moradores, aqueles que permaneceram no local, escondem-se no interior de suas casas. 0 Bexiga transformou-se numa "vitrine noturna". Nas calçadas, em lugar das antigas cadeiras, encontram-se hoje os automóveis e transeuntes, consumidores fo lugar. Os antigos casa rões soterrados no interior de verdadeiras muralhas de edi fícios. Quem olha para as fachadas das casas que sobrevive ram encontra nas mesmas os mesmos sinais das mutilaçōes. Desfiguração do desenho original para abrigar as novas fun 


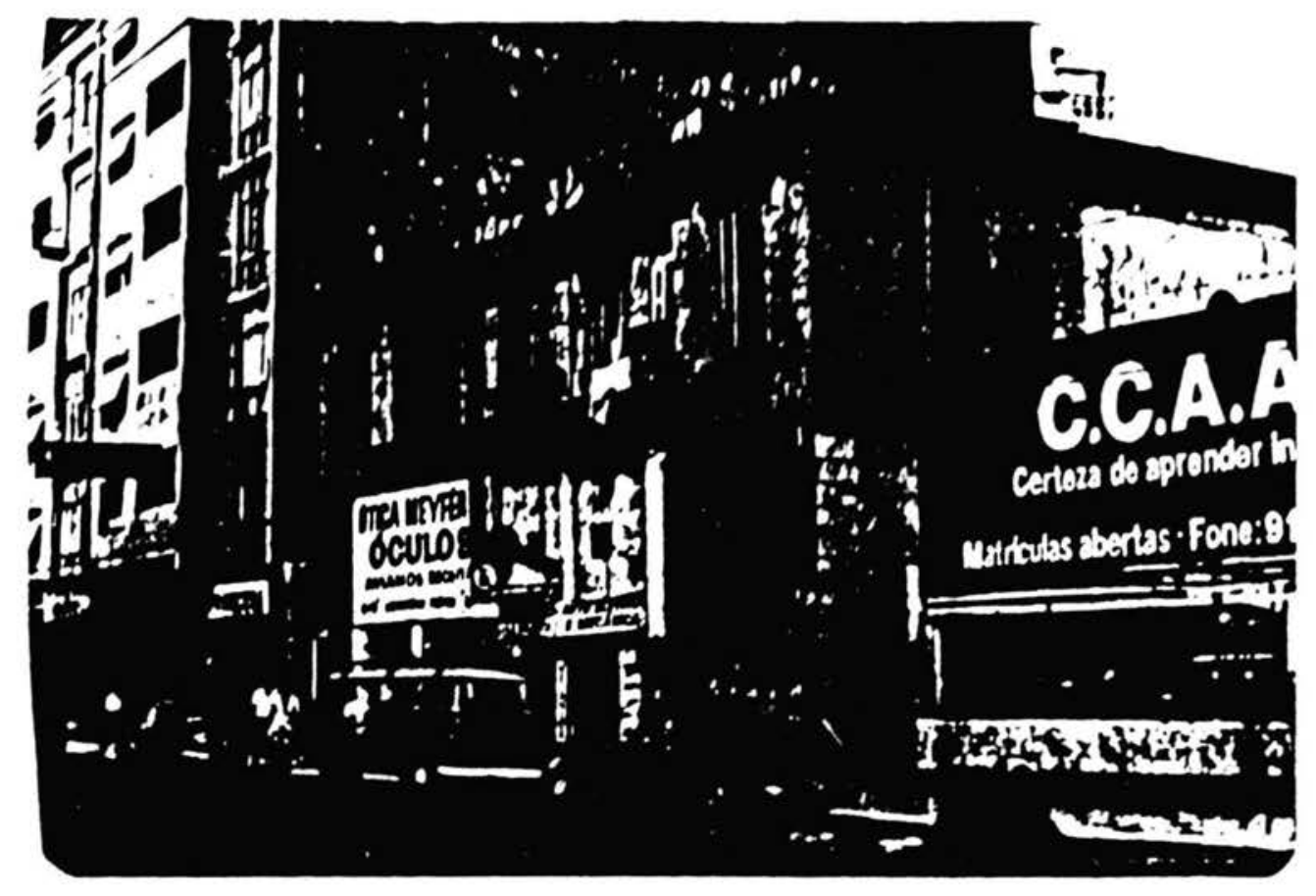

Foto 10: Casarão localizado na rua Santo Antonio. Observe-se a desfí guração do mesmo para abrigar as novas atividades.

(Ano: 1988)

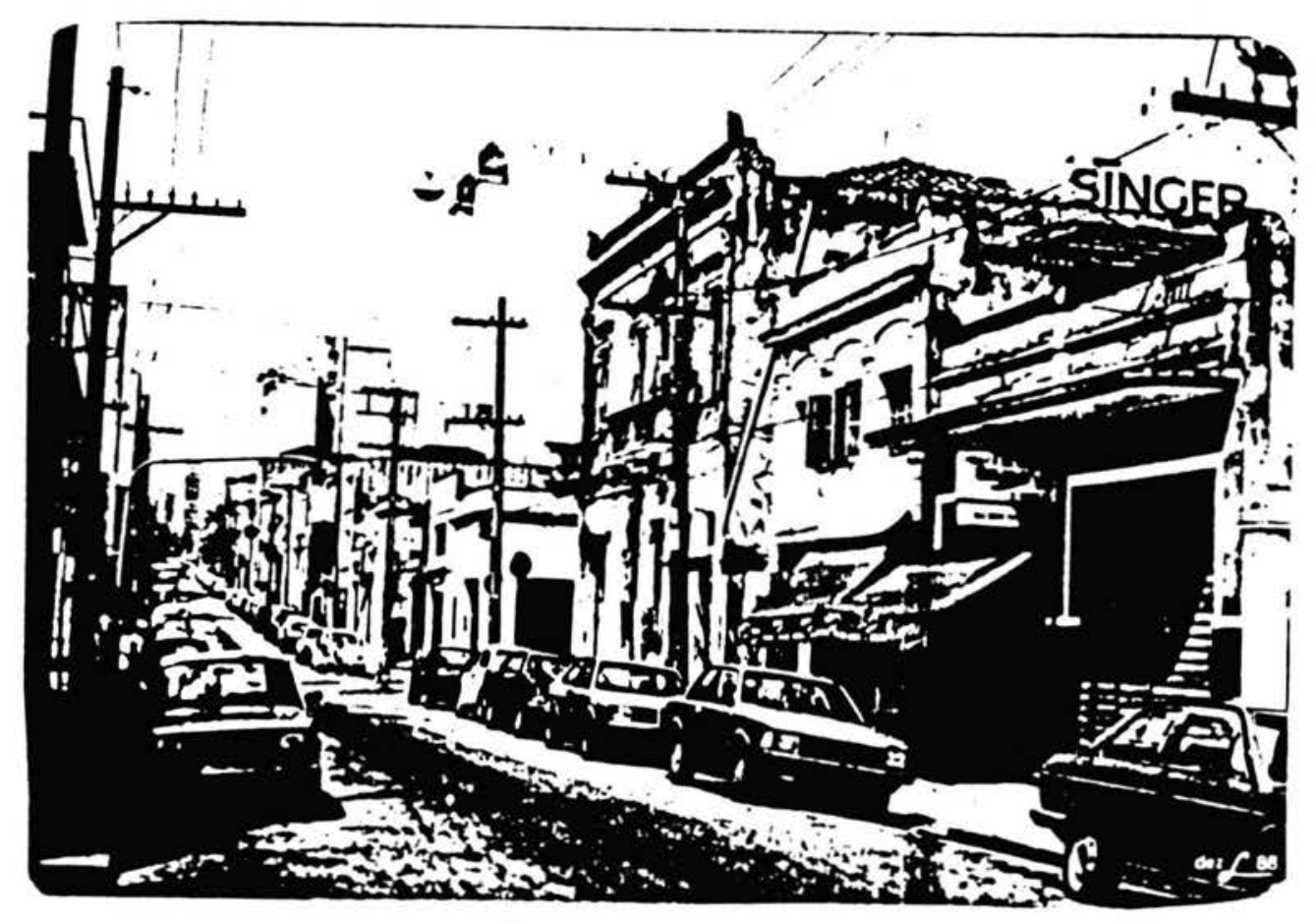

Foto 11: Rua Conselhei ro Ramalho. Deterioração e descaracterização dos casarões. Observe-se a quebra de escalas em função da verticalização da ärea. (Ano: 1988) 
coess. letrejros imporvisndos, janclas, portas c frontais desfigurados. Aos poucos ele transformou-se num amontoado de fragmentos - "um mundo de miudezas", de coisas que parecem provisórias. Para os antigos moradores a rua ficou do lado de fura". Aquela antiga unidade. - casa e rua sobre a qual tanto se falou e que alguns querem ressuscitar, para nós, na sua quase totalidade está perdida. Ele é hoje aquele bairro exótico, onde se consomem "produtos embala dos" - um novo "travestido de antigo". Um tradicionalismo de "muletas". O bairro e seus moradores transformaram-se em "folclore". Sua presença hoje é cada vez mais a representação de sua ausência. Um mundo do imaginário para aque les que querem ressuscitä-10 ou enclausurar-se na ideologia do "Bixiga" como forma de justificativa de uma existên cia passada.

Cabe-nos neste momento, retornar a uma ques tão lançada no início do presente capítulo - a noção do be 10. Após estas reflexões permitimo-nos chegar à seguinte conclusāo: o belo pode ser entendido como o gozo sensorial que nasce no prazer do encontro do homem com sua obra. Sen sibilidade apreendida na plasticidade da obra como resposta a um nivel de necessidade - material ou espiritual sensibilidade integradora; no caso do Bexiga tudo nos leva à crer, que pelos desencontros entre os homens com este é paço - populaçōes tradicionais ou forasteiros, a noção do belo parece ficar distante na dimensão estética do bairro. 


\subsubsection{Sobrevivencias c mistificasoces:}

uma idcologia do "lixign"

"Okha io ti falo uma cosa, io ti falo sincero, a gente queria que volte que era atrās, mas $\bar{e}$ difficile" (Depoimento de Salvatore del Savia - Morador da Rua 13 de Maio, fevereiro/1987).

0 conjunto das mudanças ocorridas com o bair ro, acabou revelando a presença de uma população tradicio nal cada vez mais minoritária. Seja pela redução numérica da mesma, ou pela presença de novas variāveis sócio-cultu rais surgidas no bairro à partir daquele momento.

Apesar de não termos a expressão numérica da mesima, através daquele balanço demográfico e pelos depoimen tos obtidos, podemos chegar àquela conclusāo: "Eu ressuscitaria no Bexiga as próprias casas... os amigos que foram em bora. O progresso levou os italianos e seus descendentes" (Valter Taverna, Presidente da Sodepro, Depoimento de 26/3/ 88). Em vários outros depoimentos o fenômeno comprovou-se . Entre eles, o de um morador do bairro hā mais de sessenta anos: "Os italianos, para falar a verdade, sumiram todos do bairro, porque quando o governo começou a construir os viadutos, entāo desabrigaram muita gente. Foram tudo para longe. Hoje tem muito pouco daquele tempo" (Sr. Humberto Co sentino, Alfaiate, Jardim Heloísa, 53, Fevereiro de 1987).

Aquele conjunto de desapropriações e o processo da qualidade de vida do bairro com o processo de aden samento dos cortiços, a não mais entrada de italianos, fo- 
ram elementos que explicaram o esvazjamento da população tradjejonas do mesmo. Quase sempre a Jitcratura critica so bre o bairro colocan-no como se o tradicionalismo tivesse permanecido com a mesma intensidade, ou então de forma mui to genérica. Como se existissc uma "frente" numericamente grande lutando por estas tradiçōes. Como veremos logo a seguir, quando esta aparece, geralmente é representada na forma de discursos contraditórios e revelando posições cheias de conflitos emocionais. Sentimentos de perda e desencantos com o bairro. Estes grupos que representam o tradicionalismo do Bexiga, pela própria diversidade das classes em que se colocam, acabam tendo internamente comportamentos diferenciados quanto à forma de reagir perante as mudanças.

Para os grupos tradicionais de baixa renda a expectativa é quase sempre de nostalgia e impotência. De aceitação, como fato consumado, da perda de identidade do bairro e suas tradiçōes: "Nós que atingimos uma certa idade gostaríamos que isso voltasse - porēm é uma ilusão...Ho je é tudo interesse" (Osvaldo Farollo, Morador do Brás, Aposentado, frequentador do Bexiga há muitos anos). Este mesmo sentimento foi percebido em outra antiga moradora do bairro. Dona Tereza Sabino Bezerra, morando no Bexiga há 65 anos: "Eu gosto do bairro, já me acostumei... Assim como eu, outros dizem - antigamente era melhor... 0 que mais me lembra do bairro era ficar depois do jantar na porta da rua... Todos eram bons... Em relação às coisas antigas para mim é indiferente, pois continuo minha vida assim como é... Eu fico aqui dentro" (Depoimento, Fevereiro/87). Quando nāo colocados textualmente como nestes depoimentos, os demais através de 
uma lejtura swas entrejinhas achatm revelando o mesmo sentimento.

Entre os grupos sociais de maior renda,prin cipalmente os representativos do grupo das cantinas, moradores bem sucedidos como empresários no bairro, o ânimo é outro. Entrc aqueles mais famosos, os que mais vêm se destacando na luta pelas tradiçōes do Bexiga, temos Valter Ta verna, proprietário de uma cantina e Armando Puglesi, proprietário de outra: a Cantina do Museu. 0 primeiro foi fun dador da Sodepro, o segundo do museu que leva o mesmo nome da cantina - Cantina do Museu, bem próximo do mesmo. Ambos, apesar de terem seus interesses ligados ao bairro, não residem mais no bairro. Sobre estes dois representantes das lideranças na luta pelas tradiçōes, é comum encontrarmos , nás mídias e literatura crítica sobre o bairro, seus nomes ligados a algum movimento relacionado com aquela luta. Assim se expressa uma das escritoras mais tradicionais sobre o Bexiga:

"São inúmeroś os batalhadores e militantes pela preservação e divulgação do bairro, po rém a figura simpātica de Armando Puglesi traz em seu sangue o amor arraigado pelo Be xiga" (Lucena, p. 232).

"O bairro estā um pouco descaracterizado. Pa ra resgatar e manter suas tradiçōes, temos que trabalhar em paralelo com São Paulo" (Depoimento de Valter Taverna).

0 fato de ser a Sodepro, segundo depoimento de Valter Taverna, constituida, na sua quase totalidade por comerciantes do bairro, permite-nos ver a instituiçāo mais como um 'órgão de classe' do que propriamente da comuni dade representativa do Bexiga como uma totalidade: "A Sode 
pro tem 12 abementos nós organjzamos, resolvemos as coisas por tejefone. Jendo um jucalista nós resolvemos as coisas de imediato. Intre os poucos que existem, temos os comet ciantes de outros tipos... é mais quele ṇue têm a cabeça no lugar" (Depoimento de Valter Taverna, 26/3/88). Una caracterís tica dá instituição é ser muito pouco formal, parecendo constituir-se na essência, pela iniciativa dos seus membros. A sede da mesma fica na cantina do seu fundador. A representatividade destes donos de cantinas pode ser percebida pela maneira como os mesmos são destacados dentro da imprensa: "A revolta de Armando Puglesi, criador e único mantene dor do Museu do Bexiga, dono da cantina do Museu, ambos na rua dos Ingleses, o representante da região no movimento "Defenda São Paulo" é, sem dúvida, uma forte liderança 10cal e um exemplo típico do morador tradicional desse que é um dos bairros mais peculiares da cidade. Armando não es conde sua revolta por mais esta tentativa de desfiguração do velho Bexiga ameaça até "quebrar a cara" dos que pretenderam executā-1a" (Shopping News - 30/8/87).

Muito mais do que registros das imagens e sentimentos, estes depoimentos foram aqui invocados para demonstrar os papéis das diferentes pessoas e as respectivas posiçōes sociais das mesmas no processo de luta pelas tradiçōes do bairro. Para aqueles mais humildes um mundo de desencantos. Para os outros, aqueles mais bem sucedidos, a tentativa de resgatar as tradiçōes, as cantinas e mesmo algumas formas de diversōes: "O que restou é muito pouco casas tradicionais, cantinas, restaurantes, é a única tradição que restou. Devemos lutar para melhorar a imagem do Bexiga para trazer muito mais turistas" (Valter Taverna). 
$\Lambda$ percepsüo da mudança $e$ sentida nestess dis zursos, porém, o sue devemos cercar agora a a forma como Estas mudanças sĩo percebidas pejos mesmos. O nivel de pro fundidade c clareza que a mesma apresenta em relaçāo ao que realmente mudou no bairro. Entre os elementos apresentados como tendo sobrevivido, pudemos arrolar alguns, com os quais estabelecemos um confronto com aquilo que nós ef é tivamente conseguimos ter observado como sobrevivências. A sim, através destes confrontos, procuramos trabalhar os $n \underline{1}$ veis da ideologia e.do imaginārio naqueles discursos. Entre os referenciais arrolados, relacionamos os seguintes : Alguns pontos de encontros, ruas, esquinas, o casario, a igreja e suas festas, as cantinas, os teatros e a escola de samba.

Ruas e esquinas, como lugares comunitärios do antigo Bexiga parecem ter se sentido nas lembranças da população. As esquinas da Rua 13 de Maio com a Rua Conse lheiro Carrão e desta com a Rua Rui Barbosa foram aponta das como um dos pontos da boemia do bairro. Hoje, cruzamen tos vitais para o trânsito que faz ligações entre o corredor das avenidas Nove de Julho, Brigadeiro e Av. Paulista. Lugar de grande intensidade de transeuntes, principalmente nos finais de semana quando os consumidores invadem o Bexí ga. Ponto de grande concentração de cantinas e casas de shows. Torna-se dificil pensarmos hoje a possibilidade de qualquer tipo de relação comunitāria em pontos como estes. Naqueles relatos percebemos o sentimento de perda da posse dos lugares. Ficou muito mais como representação simbójica do que efetivamente como uma realidade que tenha sobrevivi do. 
Sobrc as antigas casas - aquelas construi -

das pejos "capomastri", das quais tanto sc orgulham, as referencias são sempte ambíguas. Apresentam-nos como sobre vivências, mas ao mesmo tempo apontam-nas como a presença da "degradação do bairro: "antigamente tinha muito cortiço, tinha, casas de cômodos, mas... era cortiço bacana, era casa de comodo, nāo como agora, como atualmente tem agora.Fu morei numa casa de cômodo grande, que era aqui pegado do meu sogro, mas era uma coisa só, todos os vizinhos se ajun tavam à tarde, tudo em volta do quintal, tudo brincava, tí nha um que trazia cafezinho, outro sanduiche, era diferente" (Rita Rosa Albanese, proprietāria da Padaria São Domin gos, 14/10/83, DPH-PMSP). Assim prossegue outro morador an tigo do bairro: "Hoje tiveram muitas construçōes - Eu gostaria que as tradições fossem preservadas - Gostaria que minha vila fosse preservada - Gostaria que estes casarōes deixassem de ser favelas. Cortiço para mim era quando se construía no fundo da casa, lugar 3 ou 4 familias. Hoje em cada cômodo dos casarões mora uma família" (Felcio, mora dor há 65 anos da Vila Antunes, entrevista 26/3/88). Vimos, assim, lembranças dos casarões com saudades. A presença atual dos mesmos pode ser considerada a prōpria ausência do que foram no passado.

Pela maneira como apresentam os teatros naquele conjunto de elementos que tiveram sobrevivência, parece-nos que são a continuidade do que foram no passado.Na verdade, o bairro teve um único teatro - o Espéria, hoje demolido para dar lugar ao atual Sérgio Cardoso. Somente em 1948 é que foi construído o atual Teatro Brasileiro de Comédia o TBC. Espéria e TBC, estes sim podem ser organica mente considerados como parte inte- 
grante das tradiçós histórjcas do kexiga. Aquele por ter sido o grande símbolo da jabianjade do bajrro. lugat fre quentado intensamente pela comunidade jtaliana para assistirem a peças teatrais, na sua maioria com temas e compa nhias italianas. O público deste teatro era dominantemente do bairro. Quanto ao TBC, pode ser condiserado um marco pa ra a cultura de São Paulo e para o Bexiga, à medida que inaugura, de forma ainda tímida, a fase das diversōes que mais tarde invadiram o bairro. Enquanto o Espēria era o teatro do bairro, O TBC passou a ser o de São Paulo, abrin do, assim, aquele processo de transformação do Bexiga num lugar de lazer para a cidade. Bem mais recentemente é que - Bexiga transformou-se naquilo que muitos apelidaram de - a "Broadway" paulistana, pelo grande número de teatros que ocuparam este espaço e pelas famosas peças de teatros que ai foram encenadas.

Assim, quando nos discursos, os teatros sāo apresentados como sobrevivências do antigo bairro, como se fossem a continuidade do cine-teatro Espéria, não percebem que suas relações com o lugar eram diferentes das atuais. O Espéria era um lugar de encontro da população 10cal não somente para os espetáculos teatrais ou cinema.Era - lugar onde quase todos os grandes eventos aconteciam:des de bailes de carnaval freqtentados pelas familias locais, como qualquer tipo de espetáculo cultural relacionado ao bairro. Não se percebe que na verdade, a população que hoje mora no Bexiga foi expulsa do interior dos teatros.

Para as cantinas, o destino não foi muito diferente. Com raízes na tradição italiana que povoou o Be xiga, foram surgindo como locais de encontro, onde se joga va carteado, se cantava e se bebia o vinho importado da 
lájia, acompanhado de antepastos. Assjm surgiu a primeira c mais famosa cantina do kexipa, a Cantina Capuano, instaJada na rua Major bjogo, próxjmo de onde futuramente se instalou O TBC. Eram lugares que se caracterizavam como prolongamento da residência dos seus proprietários. A iden tidade italiana era ai fortemente estimulada, falavam-se os dialetos, principalmente o calabrês. Eram verdadeiras escolas de italianidade. Filhos e netos aprendiam o dialeto dos seus pais nestes momentos de convivio muito estreito com a comunidade, assimilando os costumes dos imigrados. A partir da Capuano foram surgindo estes tipos de estabele cimentos. 0 aparecimento do $T B C$ e de uma vida artística no pedaço foi criando na rua Major Diogo e suas proximidades um espaço de lazer e cultura.

A Capuano passou à partir de então, a ampliar os tipos de refeições, feitas num verdadeiro ritual pelo seu proprietário. Esta somente funcionava à noite. Quando repleta, as portas eram fechadas, pois a proporção de comida era controlada em função da lotação da casa. 0 salão de refeiçōes era revestido de muita simplicidade,po rém acompanhada por uma grande hospitalidade do velho Capuano. Existia um verdadeiro ritual realizado pelo mesmo sentar-se junto aos seus fregueses, compartilhando das mesas em longos bate-papos, quando então procurava certifi car-se que os fregueses haviam ficado ou nāo satisfeitos com a comida. Cerradas as portas, em hipótese alguria se fa $z$ iam novas comidas. Tão pouco os fregueses podiam levar co mida em embalagem. Quem quisesse que fosse comer lá.

Casa e cantina constituíam-se numa pequena unidade de produçāo: "Na minha infância, os restaurantes a gentia podia contar nos dedos de uma mão. Tinha o Capuano 
c "Roperto eque mais cu pedjo citar... ache que estes doj: : partit de 196() , aj comecou uma infinjdade dedes que : instajou aqui na regiäe de cantinas c restaurantes mest: :- (orlando Laurenti. Proprictário da padaria Basili ca t ijretor da União do Bexiga. Hoje não mais residente no Lirro. $11 / 10 / 83$ - DPH-PMSP). A medida que a população foi : mudando e com aquelas transformaçōes todas, os res taurintes e cantinas permaneceram, mas foram mudando de proprictários: "Quem morava antes aqui era a colônia italiana, tinha português também, espanhóis, tinha sírios aqui dentro do bairro, mas a maior parte era 908 da colônia italiana. E hoje eu acredito que dentro do bairro mora uns 308 ou 408 de descendentes né..." (Orlando Laurenti, Entrevista, 13/10/83).

Aos poucos as cantinas foram se transfor mando, acrescentando cardápios. Diferentemente daquelas do tipo Capuano, onde os pratos eram determinados pelos proprietários. Hoje, permanecem oferecendo junto a outros pratos típicos, os pratos da comida italiana. Foram surgindo, novos proprietários: "O italiano veio para o bairro como pequenos negociantes. O italiano é egoísta, les queriam crescer. Eles vinham aumentavam os restaurantes etc. Hoje, porém, os portugueses compraram a maior parte das cantinas italianas. Investem na comida italiana e estāo levando para a frente as tradiçōes do nosso bairro, que é importante... A cultura está se. fortalecendo no nosso bairro. Artistas moram no nosso bairro. Os maiores teatros estão no nosso bairro. Os turistas chegam mas não encontram infra-estrutura. Não temos estacionamento. O Be xiga se nāo tomar cuidado vai para a falência. Corre-se o riscc de investir e não ter retorno. 0 bairro nāo vive da 
própria comunidade. Vive-se totajmente de fora. A sodepro tem prestado mujto serviço" (Vujter laverna).

Parece-nos que os interesses empresariais e as preocupaçōes com a preservaçāo das tradiçōes por parte desta liderança encontram-se estreitamente associadas: "Através da Sociedade eu fiz algumas idéias. Fazer no bairro um centro turistico italiano, com todas minhas forças, pela sociedade e pela comunidade. Pedi para o Reinaldo de Barros um projeto para a Treze de Maio - o calçadão e um amplo estacionamento subterrâneo. Viriam outros investi mentos... Temos a feira de trocas - ela traz retorno para - bairro... Esses coitados que não têm onde se divertir, a proveitam e trazem turistas, que ao fazer o lazer aproveitam também para saborear a'comida italiana no bairro... Pe dimos para o prefeito e fizemos o projeto paraum ano reurbanizar o Bexiga. Fizemos projetos pontuais. 0 nosso proje to, eu e mais engenheiros e O IAB (Instituto dos Arquite tos do Brasil)... Eu encaminhei para o prefeito Jânio, caso venha ocorrer o surgimento dos espigões, encaminhei um projeto para preservar nossas tradiçōes, as cantinas e os teatros. A parte de baixo dos espigões deveriam ser preser vadas aos restaurantes totalmente, cantinas e tratorias, pa ra manter viva a tradição italiana, bairro onde nós nasce mos" (Valter Taverna).

Assim, aqueles restaurantes e cantinas que "sobreviveram" passaram a ser contemplados com o privilé gio da "proteção", como os "legitimos herdeiros do tradi cionalismo do Bexiga". Pelo discurso do "próprio autor do projeto" e pelo que pudemos perceber, parece-nos que os elementos contemplados estão longe de serem considerados 
como herdejos daquedas tradicies. Mesme perque, nem sempre a comunidade, como um todo, assim vê aquelas cantinas: "Com as Cantinas acabou o sossego da gente. Tem muito dadrão, muita coisa. Moradorcs saem do bairro porque não aguentam mais o movimento, o barulho, não tem sossego.Quem vem morar aqui, vem porque não acha casa... A rua 13 de Maio tinha mais italianos, tinha o bonde, as casas eram baixas. Só tinha um prédio. Não tinha o movimento que tem de carros, que ficam em cima das calçadas. As pessoas têm que passar na rua. A rua era uma só" (Sofia Donangelo Di Servi. Organizadora da Festa de São José do Bexiga, 13/10/ 83. DPH-PMSP).

Assim, parece que a tradição passou a ser um bom negócio para uns e maldiçāo para outros. Tornou-se aquela atraente "mercadoria". Se antigamente a clientela procurava estas cantinas pela especialidade da comida italiana, hoje são procuradas mais pela atração do lugar. Naquela época não se fazia necessārio defender as tradiçōes das cantinas e tão pouco a italianidade das mesmas e do bairro. Não havia a necessidade de se "travestir" o bairro com as bandeirolas e cores da Itália para definir sua italianidade. Esta existia nas casas e nas ruas. Presença viva da mesma. Hoje, simplesmente representaçōes.

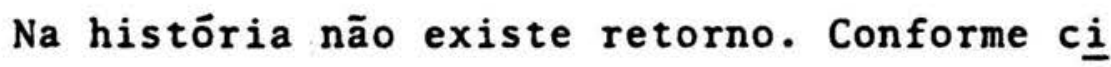
tação de Toni Bettanini, apresentada na introdução desta pesquisa, que aqui retomamos:

"Um novo espaço é construído, um velho espą ço assume uma nova dimensão de significado. Para que isto ocorra é necessäria uma dimen são coletiva. Uma dimensão coletiva ligada a uma exigência de fundamentação, refunda mentaçāo de valores". 
latecenos que nem ovelho exjste mais e tampouco o novo efetivamente se consoljdou no pexiga. podemos mais uma vez dizer: "() Bexiga é um bajrro em transe". Qual é aquele coletivo e quais são os valores? Tudo parece uma desintegração.

A Igreja e suas festas, as de Nossa Senhora da Achiropita e de São José, constituem outro marco a ter que passar pelo crivo do confronto histórico. A história da igreja remonta à própria hịstória do bairro. Localizada na rua 13 de Maio, que já foi rua e praça ao mesmo tempo, faz parte hoje daquela massa disforme de prédios e casarios. Pou co se destaca na rua, perdida no interior de uma massa de cimento. Antigamente, sua cúpula podia ser vista a longas distâncias. Hoje está escondida entre espigões que invadiram - bairro. Juntamente com as antigas cantinas, foi um autênti co simbolo daquela italianidade. A quermesse e a festa à San ta Padroeira, comemorada em 15 de agosto, foram as maiores festas do Bexiga, comemoradas com brilho por muitos anos. De pois entrou em declínio para ressurgir novamente nos últimos anos.

Durante muitos anos, a festa e sua procissão peio bairro foi reverenciada com rituais de adornos das portas e janelas pela comunidade italiana, quando da passagem da mesma, onde cada fiel fazia sua doação em dinheiro, pendu rando o mesmo com alginetes, ao longo de grandes fitas pendu radas na Santa. Neste momento, a população gostava de disputar em prestígio, demonstrando as maiores doaçōes. Assim faziam também, com as decorações das fachadas das casas. Até hoje esta procissão é realizada. Nestes momentos alguns vethos moradores dirigem-se ao bairro para fazer sua devoção. 
Porém, jä sâo outras as pessoas que peregrinam pela mesma, unjdas majs pela religiosjade do que peja identidade cus. tural. loucas são as pessoas que ainda, dos grupos tradi cionais, participam do evento. As janclas vazias, a não ser a prescença de algum curioso que espia por detrás do vidro; ou então, roupas penduradas para secar, aparecem co mo "símbolo do forasteiro" que vê tudo aquilo com uma certa estranheza.

Quanto à quermesse, esta ficou desaparecida do bairro por longos anos, confinada ao interior do pátio da igreja. Após aquele "Ano Zero" com o advento da entrada do bairro naquele circuito da "indústria do lazer" a quermesse voltou às ruas: "A Sodepro tem feito muito para a igreja. Ela trouxe a festa para a rua. Resolvi junto ao padre ao lado do terreno. da igreja uma cantina. A partir dai todos os anos fizemos a quermesse que faz crescer a fé a Nossa Senhora da Achiropita" (Entrevista, Valter Taverna). Para Orlando Laurenti, diretor da União do Bexiga, a histōria assemelha-se à anterior: "A Uniāo do Bexiga che gou pro vigário uma ocasião e falou que nós teríamos como trazer a festa prä rua novamente como era feito antigamente... De fato o padre aceitou a idéia, a Uniāo do Bexiga juntou aos poderes públicos, conseguiu barracas, previu a divulgação. Então a festa foi um sucesso muito grande em 1978, no primiero ano que nós fizemos, realmente valeu a pena e está sendo continuada, a festa está sendo feita na rua, com isso a Paróquia estā arrecadando bastante dinheiro, pra ampliar a creche" (Entrevista Orlando Laurenti, 13/10/83 - DPH).

Esta quermesse acabou se transformando no grande evento nos dias de hoje para propagar o tradiciona- 
Jismo do Rexiga. Istimulada pela midja-tedevisão, jornajs, rúdio etc. passou a "ressuscjtar a italianidade do bexiga". licnte de toda parte aparece na época do cuento: "Existem dois tipos de pessoas que participam por ocasião da festa da Achiropita. Tem aquele pessoal que são dos movimentos pastorais... colocam à disposição de trabalhar nos fins de semana dedicando este trabalho como devoçāo de fé à Nossa Senhora. Depois tem um grupo que aparece só na época da festa pode-se dizer que é um grupo de apoio, são grupos de voluntários, que já saíram do bairro... e também para rever os amigos" (Irmão Afonso Faustino da Igreja N. S.Achiropita, 13/10/83, DPH-PMSP). A Paulistur vem, nos ūl timos anos, colaborando na organização da festa que já se transformou num evento de São Paulo.

Hoje, sua organização e dimensōes atraem pạ ra aquelas ruas um tipo de público diferente daquele que costumava frequentá-la nos primeiros tempos. Antes era uma festa do bairro, na verdade, dos italianos de São Paulo, pre ferencialmente os calabreses. Hoje ela é um "campo de bataIha". Filas infernais para se comer uma "fogazza", prato típico italiano. Gritos de "pega ladrão", apertos por todos os lados. Entre as poucas coisas que evidenciam a presença de uma ligação com o passado, além da presença física da igreja, são alguns cumprimentos, apertos de mão de antigos moradores que nesta época visitam o bairro para re lembrar a festa. "Velhos Bexiguentos" - verdadeiros estran geiros no meio daquela multidão que invade o bairro "para curtir" a festa. Apresentada como exemplo de uma italianidade, com suas "bandeirolas com as cores da Itālia", que se não tremulassem sobre as cabeças de alguns poucos "bex $\underline{i}$ 
guentos" que alj se encontram presentes, diriamos que serja um espetátculo "trúgico-comjco": "Ant juamente cu gostava da quermessc. Hoje ela é djferente - chegava até aqui em baixo. Nela tinha pessoas do bairro. Hoje eles vêm vis tar, quarido falamos daqueles tempos. Hoje o nümero de pessoas é maior. Na quermesse aumentou o número de estranhos". (Tereza Sabino Bezerra, moradora do R. 13 de Maio, fevere ro de 1987). Para a realização da quermesse o trânsito tem que ser interrompido no trecho da rua, o que cria um verda deiro transtorno para a circulação dentro da área, sendo obrigada a constante permanência da polícia, inclusive para conter os "batedores de carteiras". Outro elemento a ser observado é que, os espetáculos onde se apresentam as mús í cas italianas são realizados em ambientes fechados, nem sempre com preços acessíveis às camadas de baixa renda.

Outra festa, que jä teve maior brilho, é a de São José do Bexiga, o primeiro padroeiro do bairro. $\AA$ medida que a colônia calabresa aumentou no lugar, com a construção da igreja, na qual foi introduzida a imagem e veneração da Santa, somente o nome do antigo padroeiro do bairro permaneceu. Sua festa era comemorada naquela vila já mencionada, que foi derrubada recentemente para a construção de prédios comerciais. Para que a lembrança do santo não fosse esquecida foi colocada uma imagem de São José perto das escadarias da rua Fortaleza, em frente àquele anfiteatro" improvisado. O desencontro da imagem com 0 lugar fez a "emenda parecer pior do que o soneto". A tentativa de ressuscitar o passado, demonstra na maioria das vezes a condiçāo trägica da mesma: "As lembranças das festas de S. José, mais espontâneas do que hoje. As sociedades ami gos do bairro organizam a festa que antes era feita pelos 
próprios moradores" (.José . 1ambo lisho, presidente da liseola de Samba Vaj-Vaj, Lntrevista $13 / 30 / 83)$.

Passando-se pelo elevado, que corta hoje a P̧̧a. Quatòrze Bis, antigamente Santos Dumont, pode-se ver - nome da escola de Sambá Vai-Vai. Nome dado em homenagem à mesma ai localizada. Esta é trida como uma das tradiçōes queridas do bairro. Confinada numa minúscula quadra, luta para aí sobreviver: "O Vai-Vai nuaca teve uma sedẹ própria. E uma entidade que só existia na época do carnaval... Come çou a ter sede à partir de 1968 e a partir de 1975 monta ram a sede própria... Foi sempre a população carente que frequentou o samba. 0 samba ainda é marginalizado... 0 Vai-Vai agora mudou: é constituído de pessoas carentes e não tão carentes... Quem frequentava o Vai-Vai eram pessóas do bairro. 0 Vai-Vai sempre contou com pessoas do bairro desde a fundação. Passou a contar com pessoas de ou tros bairros depois da urbanizaçāo dentro do bairro, porque a maior parte dos moradores foi morar na periferia.708 dos frequentadores de fora, da periferia e 308 do bairro" (José Jambo Filho, Presidente da Escola de Samba Vai-Vai, $13 / 10 / 83$ DPH-PMSP). E bom lembrar que as transformaçōes ocorridas com a escola tem seu período circunscrito ao "Bexiga Ano-Zero".

A escola de samba, assim como as outras tra dições transformaram-se em "produtos de exportação". Ela saiu das ruas do bairro para as apoteóticas passarelas. Ob viamente que a mesma não perdeu ainda suas raízes com o bairro. Porém, deixou de ter sualexistência em razāo do mesmo. Era em suas ruas e com o próprio pessoal do bairro que realizava seus espetáculos. Podemos dizer que, se os brancos italianos tinham sua procissão como expressão da 
sua cultura, os negros também t juham sua "procissão" real zada todos os anos pelas ruas do bairro na época do carnaval. Em lugar do andor da 'santa calabresa', o standarte da sua escola de samba: "perguntando-se àqueles líderes da ré ferida escola sobre a participação da colônia italiana ne $\underline{s}$ te evento, tivemos a seguinte respostá: "Como a Vai-Vai é uma entidade cultural aberta ao povo, muitas pessoas partí cipam, mas poucas contribuem para o carnaval, os gastos são enormes. A participação da colônia é coletiva, assiste a ensaios, mas não entra com o dinheiro para um carnaval decente como o bairro merece... Para conseguirmos uma área de $4.000 \mathrm{~m}^{2}$, temos que sair do bairro e aí está nossa luta, é para mantermos nossa sede no bairro, porque se não fosse essa luta já teriam nos expulsado daqui". (José Jambo Fi1ho, DPH-Entrevista).

Ameaçada na sua identidade com o bairro,vive ainda aquela luta. Se o samba entrou pelas casas de diversōes noturnas - as casas de shows, o samba da escola, a bandonou, ou melhor, foi expulsa das suas "antigas passare las". Para o bairro, na verdade, passou a ser "mercadoria de segunda mão". 0 ganho nas apoteōticas avenidas, signifi cou a perda do seu espaço dentro do bairro: "Nós estamos impossibilitadoside fazer nossas programações como elas deveriam ser feitas, porque se funcionarmos numa quarta-feira, 5ạ feira ou sexta, chega aqui e vai ver o que? Vai ver boate, vai ver a $R$. Sto. Antonio cheia de gente. Pratica mente o que é cultura popular ele não pode ver porque só aos domingos que plílemos fazer a prática da cultura popu lar para se ver, e nesse dia não interessa ao turista...Se for para a Bela Vista virar um ponto turístico é para viver oficialmente... Eles precisam deste tombamento para 
manter a rajz dentro do bairro, senio futuramente a Vai-Vaj nào pertencera majs ao bajrro" (jdem).

Neste momento, após todos estes relatos e ob servaçōes sobre a realidade empirica do Bexiga, sobre as diferentes formas de representaçōes que são elaboradas na memória da sua população tradicional, reforçada pela mídia sobre aquelas tradiçōes, cabe-nos aqui um aprofundamento teórico sobre a natureza do tradicionalismo como uma das instâncias do processo histórico na criação do imaginário , pois, como pudemos observar, principalmente nos discursos das lideranças e na literatura acerca do bairro, os limites entre o real e o imaginário são difíceis de se perceber.

0 tradicionalismo deve ser entendido como um componente do processo evolutivo da histōria, concebido como um "estado carregado do passado, fazendo da tradição uma expressão de continuidade". Portanto, o tradicionalismo pressupōe a existência, no presente, de fatos que se susten tam pelo passado. Sobrevivências que resistem em desapare cer na dialética das transformaçōes históricas. A existên cia do arcaico na negação do novo. Nesta dialética, a tenta tiva de se "congelar" o passado, oú seja: a criação de ụma ideologia do arcaico. A preservaçāo de relaçōes que ñāo mais encontrando correspondência no presente, sustentem-śe na alienação do mesmo. E a necessidade de manter o passado de forma estátice no presente. Procura-se através dele manter uma continuidade histórica que na verdade nāo mais exis te, sustentando-se na maior parte das vezes pelo autorita rismo:

"La verdade esta, en suma depositada en una institución, $y$ por eso la historia misma 
constituy la prucha de que taj institucjón la posoa. Ina de las pruchas de ja verdad es, asi, la persitencia. De ahi que el tra dicionalismo ofrezca una prueba histórica e inclusive hitoricista de la verdad. La historia se convierte, em certo modo en el depositun de la verdad" (José Ferrates, p.822).

A tradição, enquanto uma ideologia, representa uma forma de dominação daqueles que sustentam o poder, seja ele polítić, religioso e econômico. A histó ria mostra-nos que a tradição tem sido uma bandeira de lú ta das classes dominantes. Para as demais, sempre foi sig nificado de - quando assumida, um instrumento de sua própria submissão. Através dela a classe dominante exerce a sua hegemonia. Se as instâncias econômicas representam as determinaçōes do movimento histórico, a "vontade humana " nāo é menos importante por isso. 0 homem imprime neste movimento "uma vontade de ser". A sua consciência não pode ser vista como simples mecanismo de estímulos e respos tas na dialética do espírito e da matéria. A consciência humana alça-se a um nivel de autonomia muito grande na produção do real, no processo de produção das condiçōes de existência humana. Para Hegel a consciência de si pelo desejo, torna-se essencialmente ativa. 0 desejo impele o homem a uma açãó, não para contemplä-la mas para transfor mä-1a: "um eu que transforma e cria" (Roger Gaaudy , p. 57). A consciência enquanto desejo pode șer compreendi da como a instância abstrata. E a dimensão sensível do real. Sobre a natureza do papel da consciência e da vonta de na vida social, Hegel, assim se coloca:

"La consciencia es al princípio conscien cia inmediata $y$, por consequencia, su rela cion com el objeto es la certidumbre sim- 
ple y abstrata que tienc de este ujtimo... Tal es la consciencia sensible... La verda dera libertad en cuanto moral social, esta fundada sobre la consideración de quela vo luntad no es una voluntad subjetiva, una voluntad que tenga por $f$ in interesses egoistas, sino un contenido general. Tal contenido no existe más que en el pensamiento y para el pensamiento; pero la de exluir el pensamiento de la vida social, de la re ligion, del derecho, eto es una tentativa superficial como absurda" (Hegel, p. 307. 402 e 403).

Estas afirmações de Hegel permitem-nos repensar as determinaçōes do processo histórico, as relaçōes do processo histórico, as relações entre o econômico e outras instâncias destas determinações. Negligenciar o papel da "vontade humana" como uma instância autonôma - a "consciência prática" no dizer de Hegel - é simplificar a história. Muitos querem imputar ao marxismo este simplismo, quando na verdade o, mesmo, sempre procurou negar, qual quer forma de absolutização do conhecimento humano. Não nos parece que Marx tenha praticado esta absolutização através de um reducionismo economicista na explicação da Hịstória. No seu conceito de ideologia procurou resgatar a importância das formas do pensamento na produção do real. O fato de nāo ter avançado nesta direçāo não deve ser entendido como exclusão das mesmas e seus mecanismos no conjunto das determinações do processo histórico. Isto é importante para nós compreendermos o papel desempenhado pela tradição no processo de desenvolvimento histórico do Bexiga. 
portamento socjal é pedra angular de uma formação culturas - a manutenção dos traços csscnciais de uma cultura, é an tes de majs nada uma "vontade de permanência", de continuí dadc histórica. Como tal, devemos entendê-la como uma dimensão importante na compreensāo deste real. Sustenta-se a tradição no dia-a-dia, no universo do cotidiano. Vive-se a tradição no seio da familia, da rua, igreja, inclusive em muitas instituiçōes que representam a luta de classes - os sindicatos e partidos. A sua cotidianidade torna-a uma força de resistência tão grande às mudanças. As pessoas, mesmo pertencendo a segmentos de classes diferentes, antagônicos na essência, identificam-se entre si neste cotidia no. Podemos mesmo dizer que a tradição "obscurece as cons ciências'. Coloca pessoas de classes diferentes, lado a 1ado. Neste sentido deve ser entendida como uma força reacio nária. Uma negação da ação para as mudanças. Quanto mais as forças produtivas e novas rełaçōes sociais de produção definem-se e ameaçam a estabilidade do sistema, mais este tradicionalismo é invocado pelas classes que detém o poder. Criam-se as bandeiras de lutas pela preservação da tradição. Força conservadora invocada para sustentar ou tentar reaver um poder ameaçado. De uma certa forma é uma guerra sem armas. Procura-se ganhä-la nem sempre destruindo materialmente o inimigo, porém, cooptando-o. Torna-se importante passar para o adversário a idéia que a causa pela qual lutam também é a dele. Que ambos estão ameaçados pelas mudanças. A luta contra o novo" tem que ser defendida como a forma de sobrevivência. Assim, a.classe dominante chama pa ra a luta nāo somente seus "aliados naturais", mas também seus dominados. Apelar para a emoção, para o sensível, para o imediato que os une no tempo e no espaço: impedir que 
a consciencia daquedes perceba a transparencia da verdade.

A convivencia do cotidiano da rua da praça, da igreja, esco 1a, bares, tem que ser trabalhada, como se, apesar de freqllentarem lugares que nem sempre são os mesmos, apareçam co mo tal. E aqueles que não mais existem, mas têm um significado neste processo de cooptação, terão que ser ressuscitados. Aquelas coisas que estão nos lugares comuns das lembran ças, nos sentimentos - "os vôos suspensos" de Bachelard.

Esta falta de transparência não deve ser entendida sempre como produto de manipulaçōes racionalmente $\underline{e}$ laboradas. Aquelas sobrevivências, representaçōes simbóli cas que permanecem nas lembranças nem sempre significam prọ dutos de mistificaçōes estrategicamente elaboradas para a sustentação de grupos no poder:

"E preciso portanto distinguir entre ideologias historícamente orgânicas, que são neces sárias a uma certa estrutura, e ideologias arbitrárias, racionalistas, "queridas". Enquanto historicamentenecessärias têm uma validade que é "psicológica", "organizam" as massas humanas, fornecem o terreno em que os homens se movem, adquirem consciência de sua posição, lutam etc. Enquanto "arbitrárias" não criam outra coisa senão "movimentos" individuais, polêmicas etc (não são completa mente inúteis nem mesmo estas, porque são co mo o erro que as contrpōe à verdade e a afír ma). Recordar a frequente afirmação que faz Marx da "solidez das crenças populares" como elemento necessārio de uma determinada situa ção... Outra afirmação de Marx é que uma per suasāo popular tem muitas vezes a mesma ener gia que uma força material ou algo semelhante e que é muito significativa. A análise destas afirmaçōes creio que leva a reforçar a concepçāo de "bloco histórico", em que pre 
cisamente as forcas materiajs sino o contcúdo c as idcologijas a forma, distinção de forma e conteúdo meramente didática, porque as forças materiais não seriam concchidas historicamente sem forma e as idcologias sc riam caprichos individuais sem as forças ma teriais" (Antonio Gramsci, p. 65-6).

Poucos bairros de São Paulo foram tão contemplados pela mídia como o Bexiga. Invocado pelo seu tradicionalismo, pela herança da italianidade, a mídia foi "cúmplice" na difusão desta "ideologia geogrāfica". O Bexí ga é hoje um espaço que se vende através daqueles veículos - televisão, jornal, rádio e pessoas que o frequentam, embalados pela sua "magia". E difícil encontrarmos alguém em São Paulo que não tenha ouvido falar deste tradicionalismo e italianidade, ou das opçōes de diversōes que o mesmo of rece.

A imagem que se propaga é do Bexiga do lazer e da cultura. A segregação social e a precariedade das condiçōes habitacionais, quando aparecem vêm revestidas co mo manifestaçōes "folclörica". Enfatiza-se a italianidade, quando jā vimos que ela não é mais dominante. Esconde-se as precariedades da vida daqueles cortiços como se isto fí zesse parte de "forças naturais" - a ordem natural das coisas, tão caras aos filósofos do século XVIII que influencí avam o pensamento burguēs da época. "Bexiga - Amore Mio" é - título de uma das principais obras escritas sobre o Bexí ga, pelo menos a mais difundida, no seu conteúdo percebe mos estas contradições. A pobreza aparece na mesma como "forças naturais". A italianidade parece ainda residir no bairro e possivel de ser resgatada. Dentre os artigos publicados pela imprensa jornalística, gostaríamos aqui de 
destacar um: "lim relação ao pexiga, a lisasurit informa que. até o final do més, poderá fechar um acordo com os propric tários dos imóveis localizados nas imediaçōes da igreja da Achiropita, pedindo a concessão do espaço de suas fachadas em troca de uma repintura. O projeto obedece a um levantamento histórico feito pela empresa lconográfica e as cores predominantes no sul da Itália - região de origem da maioria dos imigrantes que ocupou o Bexiga - do tom pastel, como palha, pérola, areia. Para Armando Puglisi, diretor do Museu do Bixiga - "As autoridades locais não foram procuradas pela Glasurit, mas qualquer projeto de conservação do Bixiga será recebido com alegria. Puglisi sugere que a empresa encampe um movimento iniciado pelo museu, que pretende restaurar 10 casas, datadas do início do século loca lizadas na rua Jandia, acima dos Arcos do Bixiga" (Shopping News, 17/7/88).

Um espaço mercadoria: No dizer de Gramsci,a criação de ideologias historicamente orgânicas. Ao mesmo tempo, Sodepro, Museu do Bixiga, União do Bixiga, ao defen derem um tradicionalismo agonizante, que não mais se sustenta efetivamente no presente, acabam fortalecendo aque las ideologias comprometidas muito mais em criar uma merca doria vendável que propriamente resgatar a dignidade das condições sociais da maioria da população do bairro. Movimentos no dizer de Gramsci que caracterizam aquelas "ideologias arbitrárias".

Hoje nem Bela Vista, nem Bexiga, mas sim "Bixiga". Simples jogo de palavras? Não. Apenas uma necessidade de ressuscitar aquele italianismo que agonizá com a guns poucos moradores - expressão sonora para expressar a 
forma de falar pexiga pelos itadianos. Desde que o bajro. no inicio do século mudou sua nomenclatura para Bela Vista em lugar de Bexiga, esta expressão foj caindo no esqueci mento. Nos mapas da Época escrevia-se Bexiga.

Observando-se os mapas mais antigos de São Paulo, mesmo após a mudança do nome do bairro para Bela Vista - a parte das imediaçōes do antigo Piques continuava sendo assinalada com nome de Bexiga (em letra minúscula) . No o Indicador Prático - Planta da Prefeitura Municipal de São Paulo - 1922, constavam do mapa as duas designaçōes:Be la Vista e Bexiga. Na planta de 1954 jā não mais aparecia a designição Bexiga, somente Bela Vista para toda a ārea, desde a Praça da Bandeira atē a Sāo Carlos do Pinhal.

Mais recentemente, quando se iniciou todo 0 processo de mudança e revitalização do bairro, quando apareceram as organizaçōes de defesa das tradiçōes, é que começou um movimento para se retomar a usar a expressão "Bixiga" na sua forma gräfica e sonora. Tenta-se, assim, com um "decreto linguístico" ressuscitar aquele italianismo co mo se fosse marca da mercadoria, e consolidar uma "ideologia geogrāfica". Dizendo de outra forma - as forças históricas do modo de produção capitalista, impulsionando as transfor mações do bairro, criando as novas estruturas que se conso lidaram, uma indústria e uma ideologia do lazer; ao mesmo tempo as lideranças locais e mais as bases remanescentes da comunidade perceberam a possibilidade de salvar do "nau frāgio histórico", alguns restolhos para a construção de uma nova embarcaçāo que pudesse dar continuidade à "viagem histórica". Assim, com o discurso do tradicionalismo, chamaram do "limbo da saudade", aquela populaçāo para o empré 
endimento de luta para a salvaçäo da suas tradjcöes. Unjram-sc, independemente da condição socjal. Para as lideran ças, cstava claro o roteiro da viagem - a consolidação das atividades que pudesse garantir a construção do "Novo Bixi ga", com as sobras do "Velho Bexiga". Para estes uma embar cação com porto certo: "todo aquele mercado na parte inferior dos espigōes", para aqueles que ajudaram na construção: o "barco da ilusão".

Uma ilusão cujo ritual se repete nas procis sōes da Achiropita, nas festas de São José, nas quermesses com suas bandeirolas, fachadas pintadas com as cores da Itália; ruas e esquinas, invocadas nos discursos como sobre vivências do passado, revelam-se como um mundo onde o real e o imaginärio se confundem. Invoquemos, mais uma vez Lefebvre :

\footnotetext{
"Imaginário social, levado pela linguagem em geral, suportado por imagens e símbolos determinados, comporta engodo, ilusão, mistificaçāo. A partir de um certo limite, o imaginário se separa do real e exatamente então é considerado como algo real: o consi derado como sendo o real" (Lefebvre, p. 22).
} 
II PARTE 


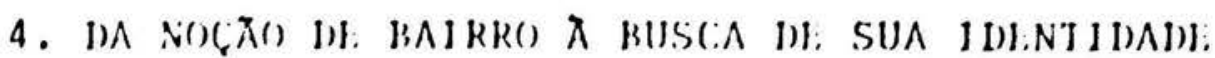

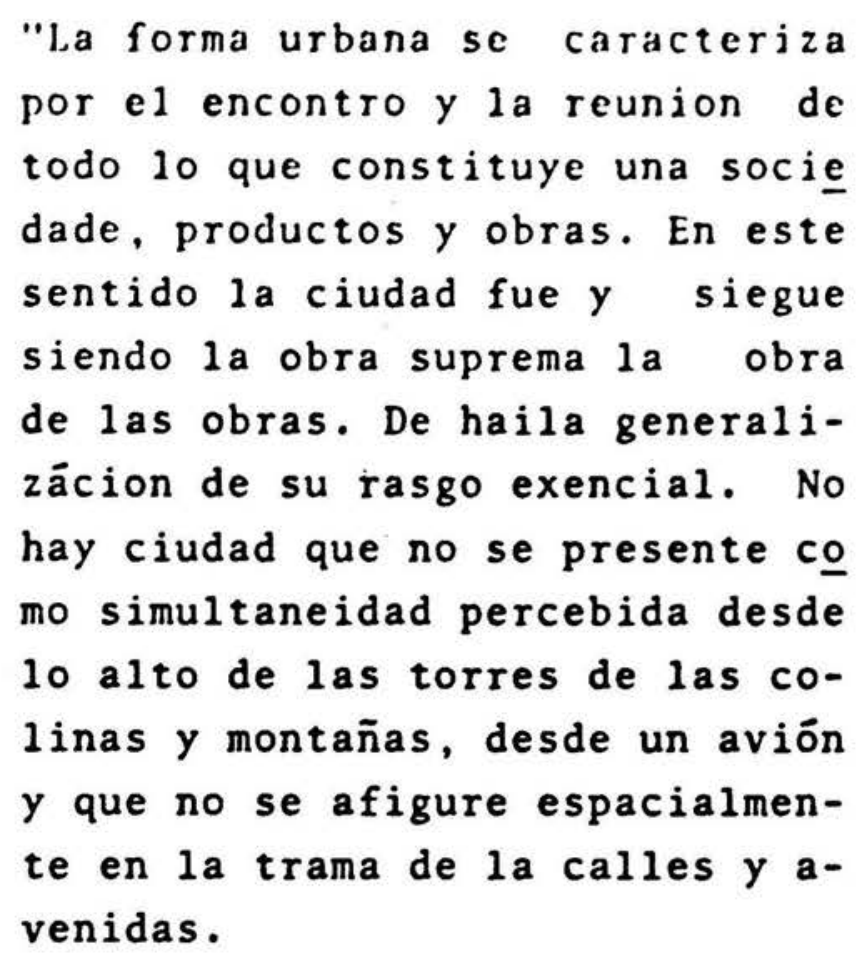

Esta determinación formal permite comprender $y$ por que las obras parecem a la vez abier tas y cerradas..."

(Henri Lefebvre, p. 237)

Um bairro tende a ser muito mais do que um têritório com limites administrativos. Ele é o resultado de um conjunto de relaçōes sociais que passam pela consciência histōrica de pertencerem a uma localidade, cujos limites podem ser definidos pelo grau de relações entre as pessoas ao viverem um mesmo cotidiano, problemas da rua ou do quarteirão, cria um clima de "cumplicidade" para viver ou encontrar saida para os mesmos. 0 bairro pode ser encarado portanto, como o lugar onde as relaçōes de vizinhança se encontram mais bem configuradas. Estes "micro-cosmos" que são as ruas e os quarteirōes tornam-se um "macro-cosmo" quando a população destes diferentes pontos é atraída pelas festas, religiosas ou sociais, aos locais 
histórjeos, que pode ser uma praça, uma rua ou a igreja.

Desta forma, criam-se representaçōes que se objetivam através de simbolos. Estes podem ser as praças. as ruas, as casas, espaços vivenciados naquele cotidiano. sempre como lugar comum:

"A formação de um polo ideal de referência, a forma espacial do aldeamento entendida co mo "revestimento ideal do mundo vivido", ob jetivação produzida pela praxis social, con duz a canalizar sobre si a variedade das experiências, a privilegiar percursos unívo cos de leitura do espaço" (Bettanini, p. 93).

Assim, o bairro torna-se uma unidade espaci al de profunda significância para compreendermos as transformações de uma cidade ou da sociedade como um todo. Unidade menor onde se reproduz grande parte da vida do cotidi ano da população urbana, é ainda o lugar onde se manifes tam importantes movimentos sociais urbanoz. As SABS (Socie dades Amigos de Bairros) mais ou menos atuantes ou existen tes em cada bairro, são uma das manifestações que ainda nos permitem, nos dias de hoje, identificar a existência do mesmo no interior dos grandes espaços metropolitanos, mesmo quando aquelas relaçōes de vizinhança jā se encon tram ameaçadas pelo novo ritmo de vida de seus habitantes.

Muitas vezes o bairro é confundido com unidades politica-administrativas. 0 crescimento da burocra cia do Estado e de uma forma geral, do poder público . criou um grande nümero de formas de intervenção sobre o es paço urbano; seja para planejar, exercer todas as formas de arrecadação de impostos e tributos, os cidadāos foram. assim, se transformando em meros contribuintes cadastrados. 
Cacla vez majs este cjadáo foj se juentificando com os $1 \mathrm{i}$ mites convencionais determinados pelo poder público, na me dida que as relaçōes sociais de vizinhança foram se esva ziando. Hoje, portanto, pensar o bairro torna-se uma tarefa dificil. Estes limites, meras convençōes, que raramente coincidem com os limites historicamente determinados pelas relaçōes sociais entre os cidadãos, deixam de guardar um fator de identidade para os mesmos. Muitos dos atuais bair ros de São Paulo, surgiram de antigos núcleos que foram se expandidndo ou se fragmentando, no dizer de Renato Silveira Mendes, levados por um "impulso coletivo", um "sentimento de localidade" muito forte. Sobre a natureza dos bairros,o referido autor, assim se coloca:

"Todavia na maioria dos casos, o que a lei reconhece como subdistrito não corresponde ao que a população reconhece como bairro,em bora o nome possa ser exatamente o mesmo. E que o bairro possui determinadas caracterís ticas muito próprias que, com o passar do tempo, se reforçam e acabam por individuali $z a \overline{-10}$ de maneira inconfundível, tanto para os que nele habitam como no conceito da população citadina... Da mesma forma Tricart acentua a importância desse conceito popu lar do que seja um bairro, considerando-o muito mais rico e mais concreto do que o resultante da divisão política-administrati va, pois fundamenta-se num sentido coletivo, idêntico ao que possui o camponês em rela ção à região em que vive.

Releva notar que, entre nós, a própria dimensão dos bairros tem uma origem legitimamente popular, resulta da voz anônima dos que primeiramente se fixaram na correspon dente ärea ou habitavam em suas imediaçōes. não dependendo dos poderes públicos - con- 
forme, aliás, já fora obscrvado por Afonso dc Freitas... Dai a extravagância de certos nomes ou, pelo menos seu caráter nitidamente popular, como os da Água Rasa, Água Funda, de Chora Menino, do Bexiga, do Brás, do Limão, das Perdizes, da Casa Verde, do Oratório, do Bibi, etc "(Silveira Mendes, p. 185).

Maria Isaura Pereira de Queiróz, em sua obra - Bairros Rurais Paulistas, define o bairro, neste ca so, o rural, como o produto de um sentimento de comunidade e apego à localidade. Para a autora os componentes que caracterizam um bairro rural são os seguintes:

"Configuração intermediāria entre a familia, de um lado, e de outro lado o arraial, ou a vila, ou a cidadezinha, o bairro apresentava as formas mais elementares de sociabilidade da vida rústica, que se alargavam em diferentes graus a partir dele, na seguinte escala: a) relaçōes familiares; b) rela çōes de vizinhanças; c) relaçōes dos bair ros entre si; d) relaçōes com a região; e) relações com o exterior (isto é com tudo que ultrapasse a região" (Pereira Queirōz, p. 4).

Apesar da grande contribuição deixada pelos dois trabalhos aqui relacionados, eles não nos permitem compreender o fenômeno na sua etapa contemporânea nas regiōes metropolitanas. Aquela identificaçāo do indivíduo com o lugar torna-se hoje difícil. Este fato, jā apontado em análise anterior, deve aqui ser novamente lembrado. A mobilidade espacial criada pelos mecanismos da economia em paises economicamente dependentes, impossibilita a fixação dos individuos em seus locais de origem. Cada vez mais fica difícil para as camadas de baixa renda a fixaçāo em qualquer localidade. A mobilidade criada com o processo de 
modernização capitalista nestas cconomias descniajzou tanto as populaçōes rurajs como as urbanas. Os desjocancntos intra-metropolitanos impossibilitam aos trabalhadores não proprictários de casas a fixação em um lugar. A possibilidade daquela identificação com o lugar era possível em épo cas passadas, mais ou menos remotas, anteriores ao grande processo da industrialização, principalmente nas economias subdesenvolvidas industrializadas. Para tanto, Mumford abre-nos uma grande perspectiva de anảlise:

"Isto nos recorda que la ciudad medieval se forma sobre el princípio de los barrios, a la voz que la igreja servia como centro de la comunidad y la plaza del moroado... todo ello a la comoda distancia de um paso corto para qualquer de suas habitantes... Si lhevamos tal comparacion a sus detalles, hal laremos que nuestros equipes resultan aun mas desamparados y fraudulentos: las panade rias vacinales de Pompeya staban (cuando ocorrio el cataclisma) haciendo de autentico pan com harina ellaborada alli mismo, en los predios cercanos a la panaderia... A todos los lugares de Pompeya se lhegaba pas so, como si sus habitantes se complacieren en visitar-se y en gozar cada uno com la compañia de los demás... Y los milles de personas que se reunian a contemplar los juegos deportivos, o ver y oir el teatro po dian abandonar sus asientos tranquilamente a casa e pio en menor tiempo..." (Mumford, p. 31).

Muitos foram os bairros que em São Paulo nasceram de núcleos rurais, ou mesmo de "bairros rurais" nos tempos das chácaras existentes ao redor da cidade de São Paulo, hoje seus pontos centrais. 0 bairro do Bexiga foi um daqueles surgidos nestas condiçōes. Pelo que jā foi 
visto, o mesmo guardou por mujto tempo suas caracterjstjcas como bajtro no sentido dado por kenato silvejta Mendes e Maria Isaura Percita de Queiroz e muito próximo do "jdeal pompeiano" descrito por Mumford. Aquilo quc ambos chama ram "impulso coletivo" e "sentimento de localidade", era encontrado no bairro do Bexiga antes das grandes transformaçōes. Para melhor entendermos a transformaçāo ocorrida no bairro como um fenômeno urbano, teremos que analisar com mais cuidado o que acabou acontecendo nas relaçōes dos individuos com os lugares de residência e trabalho.

Se aquela relação casa e rua permitiu-nos um critério para a identificaçāo das pessoas com os luga res, seu grau de integração, para compreendermos as transformações espaço-temporais, a relação residência e lugar de trabalho abre-nos uma outra perspectiva para complementar aquela.

0 lugar de residência enquanto coisa em si ou como um conjunto de representações na condição humana,é ponto de partida e de chegada no cotidiano das pessoas. A condição de classe, que dá acesso aos indivíduos a esta mercadoria chamada "casa", define a "aderência" dos indiví duos aos lugares. A condição de proprietārio ou não proprí etário acabará definindo o processo de organização do seu cotidiano. Para aquele que se torna proprietārio, é possível fazer projetos permanentes de vida no lugar - escolha de escola, clube, locais de lazer, compras e uso dos demais tipos de serviços que a vida urbana impõe. Para os outros, aqueles que vivem de aluguel, a condição quase sem pre é a transitoriedade. Este fato, obviamente estará rela cionado ao nível de renda desta população que vive de aluguel. Esta transitoriedade é maior para as populaçōes de 
renda c qualificação bajxas.

Assim, aqueda "aderéncia" ao lugar, ou scja, a possibilidade de permanéncia e constituição daquelas representações que permitem a identificação com os lugares estará numa relação direta com as condiçōes sócio-econômicas das pessoas. Quanto maior for o tempo de permanéncia, - nivel de interação tenderá a ser mais amplo e, com ele a intensificação dos papéis sociais e sua complexidade tenderá a ampliar-se. Criam-se comportamentos esteriotí pados. Para Agnes Heller o fato se coloca da seguinte forma :

"A imitação manifesta-se sobretudo como imí tação dos usos. Em todos os estágios do desenvolvimento social o homem nasce num mundo jā "feito", numa estrutura consustudinária já "feita"... o homem jamais se enfrenta com usos isolados, ele os "aprende" numa totalidade relativa, como sistema como estrutura... Estes sistemas constituem o fundamento do sistema de "reflexos condicionados", sistema que permite aos membros de uma sociedade mecanizar a maior parte de suas açōes, praticá-las de um modo instintí vo (mas instinto por aquisiçāo, não como re síduo de uma estrutura biológica), ou seja, concentra o pensamento, a força moral, etc., nos pontos concretos exigidos pela realização de novas tarefas" (Heller, p. 88).

Podemos transpor aqui o pensamento da autora para a compreensāo do cotidiano na formação da noçāo de bairro. Aquela idéia de totalidade relativa pode ser entendida por nós como o bairro, como uma parcela de espaço hís toricamente determinado - aquela teia de papéis que desempenhamos no nosso cotidiano que nasce com a interação com - espaço. E desta forma que produzimos aquelas representa- 
söes e o nives de "aderencia" ans lugares. Onanto mais se vive o lugar e mais fortes forem as relaçōes cmotivas com - mesmo, mais registrado estará na nossa memória e consciência. Nossa rejação com o mesmo passa a ser feita de forma "instintiva". O fato de se ter nascido e vivido num me mo lugar, vivenciado a infância, adolescência, casado, fre quentado os mesmos lugares, cria vínculos muito fortes com o mesmo. Criam-se códigos que permitem logo identificar o "forasteiro". Este nível de "aderência" fará com que, para alguns, aqueles papéis, "interiorizados" ou não, se tornam algo contingente; para outros a própria extensão da existência.

Se o lugar de residência pode ser considera do como componente importante no nivel de "aderência" ao espaço, não menos importante é a relação que este desempenha com o lugar do trabalho. E dentro desta relação "totali zante" que deveremos encaminhar nossa anālise. Aqui, mais uma vez a condiçāo sōcio-econômica, a condição de classe , acaba constituindo-se em fator determinante na explicação do processo. O nível de qualificação e renda do trabalha dor coloca-o em condições diferenciadas. Um alto executivo acaba criando um tipo de papel social e "reflexos condicio nados" diferentes de um trabalhador metalúrgico. As formas de interação e comportamento social diferenciam-se não somente quanto ao maior ou menor "requinte" na realização de suas tarefas, mas também na própria maneira de usarem os espaços no trabalho. Os "colarinhos brancos" e aqueles que usam os "macacōes" acabam definindo espaços diferenciados. Se a condição sócio-econômica acaba criando comportamentos condicionados em função da condiçāo técnica-profissional e de renda dos indivíduos, o processo de estratificação, que 
nasce destas diferencas sociajs, constrói também cspacos es tratificados no interjor dos locajs de trabalho c, consequentemente como reflexos destes, nos de residencias também. Sc o lugar de trabalho aproxima por necessidade técnica e económica as pessoas, os "colarinhos brancos" das que usam "macacōes", em contrapartida estas diferenças sociais os colocam em condiçōes de habitaçōes bem diferenciadas. Pa ra os primeiros, os bairros de alto padrão; para os segun dos os bairros periféricos - aqueles da auto-construção ou dos cortiços e favelas. Para os primeiros a distância entre lugar de trabalho e residencia são resolvidas com o uso das vias expressas, para eles construídas; para os segundos os longos e "sinuosos" percursos pelo interior das ruas de infindáveis bairros, apertados no interior dos coletivos ou na melhor das hipóteses, em ônibus fretados pelas empresas.

Desta forma, os papéis e os esteriótipos que criamos no interior das totalidades que nascem do nosso con vívio social e do nosso cotidiano são significativos como instâncias ideológicas que emergem das nossas experiências interativas com os diferentes espaços. Na medida em que os locais de residência e trabalho são aqueles com os quais permanecemos em contato mais tempo, eles acabam desempenhan do um papel muito grande na formação daquele cotidiano. Se para o homem de Pompéia o lugar da residência e de trabalho confundiam-se pela sua proximidade, assim como para o paulistano que habitava na cidade no século passado e mesmo no início do atual, então era aqui possível viver-se muito,pró ximo do "estilo pompeiano".

O processo de metropolização - adensamento central e horizontalizaçāo pelo crescimento "periférico" . com suas grandes avenidas, auto-estradas criou um novo cotí 
diano que passou a ser determinado por dois grandes parâme tros: velocjade c distância. Criou-sc uma nova relação do indjviduo com scus lugares de residencia e trabalho. A metrópole contemporânca gerou uma verdadeira cirurgia plástí ca no espaço. As antigas cidades, pelo seu tamanho reduzido e menor complexidade na divisão social do trabalho, ao lado de um menor número de pessoas, permitiam uma maior proximidade entre residência e lugar de trabalho. Geralmen te os bairros representavam, em São Paulo, muito mais lugar de residência e o "centro" o lugar de trabalho. Alguns bairros em função de sua evolução histōrica e mesmo em fun ção de uma certa distância em relação a este centro, podiam ter uma maior "autonomia" em relação ao centro. Porém, - "centro" da cidade era o referencial básico de organização do cotidiano das pessoas, fosse enquanto "representação" ou como forma efetiva de organização para o trabalho. Para muitos o acesso a este centro podia ser feito a pé. A metropolização, com seus grandes eixos radiais-concêntricos, e as vias perimetrais colocando residências e locais de trabalho em extremos cada vez mais distantes um do outro, fragmentou o homem, colocando-o sob um processo contínuo de "pressões", tanto o "colarinho branco" como o trabalhador de baixa renda. Obviamente que para este ültimo a situação tornou-se mais dramātica. Grande parte da energia do homem que vive nestes grandes espaços urbanizados è gas ta percorrendo espaços que thes são "alheios", mas que passam a constituir seu cotidiano. Espaços que vê mas não vivencia. As distâncias criaram uma forma de alienação do "novo homem" com o "novo espaço".

A partir destas colocaçōes podemos nos perguntar o que é o bairro enquanto uma dimensão de espaço. $A$ 
medida que as especializaçöes do trabalho definem-se no in terior de novas relaçōes de produção. induzindo uma nova escala de "velocidade" não somente para os transportes,mas também, para a realização das novas tarefas impostas pela nova divisão do trabalho, aqueles tipos de papéis e esteriótipos multiplicam-se, o homem tem que vivê-los numa sucessão cada vez mais rápida e em lugares cada vez mais diferentes. Os fluxos de serviços e pessoas seguem por caminhos sobre os quais o homem comum perde o controle. Aquela mão invisivel do que Adam Smith falou sobre o capitalismo liberal, que conduzia o homem por caminhos com "mão dupla", hoje o conduz por "caminhos com mão única". As posiçōes em que os indivíduos estão colocados escapam às possibilida des de opção. Cada vez mais a escolha quer do lugar de morar, quer de trabalhar está fora do alcance de muitas opções. Os trabalhadores, sempre encolhidos, dificilmente es colhem no sistema. O mercado de trabalho e o mercado imobiliário é que definem os limites das "opções". Estes meca nismos de poder dos mercados estão cada vez mais centralizados em formas monopolizadas de poder. Segundo Memford:

"Si los lugares en que vivemos y trabajamos fuesen en realidad aptos para habitacion hu mana permanente, por que habriamos de gastar tanto de nuestro tiempo em marcharmos lejos de ellos?... Es que hemos aceptado uma existencia como las lineas de montaje, en la que todas las funciones humanas se realizam de un medio ambiental cada vez más esterilizado $y$ uniforme apartado de todas las realizados excepto de las que están al serviço de las maquinas" (Mumford, p. 35).

Ao que Mumford chamou de aceitaçāo nós chamamos de determinação histórica - a imposição daquele "ca- 
minho de mão única". Nesta medida, a relação que os indiví duos definem com os espaços será sempre consjderada trans ja tória. Esta maior ou menor transitoriedade será, como já afirmamos, uma consequência da sua condição sócio-econômica. Para o trabalhador de baixa renda, a realização do "sọ nho da casa própria" como segurança dentro de um sistema em que a regra é a insegurança no trabalho, significou uma distância cada vez maior entre este e a casa. Esta "raiz" conseguida com o solo, significou o sacrificio de longas horas no interior do transporte coletivo. Vale aqui pensar mos na difusão da auto-construção na periferia da cidade.

Aquela dimensão de vida comunitāria da "cidą de pompeiana", acabou se restringindo cada vez mais a um processo de "atomização" do lugar de pernoite e trabalhar, variando em grau e natureza com a condiçāo sócio econômica dos individuos. Esta "atomização" das pessoas e funçōes de fine hoje a essência do fenōmeno metropolitano - fragmenta ção de espaços e pessoas. "Existências quebradas" - pessoas que têm que se dividir entre trabalho e residência num ritual torturante do transporte e da distância. Os transportes e as grandes avenidas unem os territórios, porém isolam as pessoas dos lugares. 0 conjunto dos bairros que caracterizam a totalidade dos espaços metropolitanos encontra-se unidos pelos trilhos e rodovias, porém cada vez mais a cidade se esvanece como uma totalidade vivencia da.

Quanto maisøo capital integra seu espaço $1 \underline{i}$ gando os pontos mais distantes, jogando os homens no interior daqueles "pêndulos" alucinantes do fluxo viärio metro politano, cada vez mais isto nos faz pensar o urbanismo ca 
pitajista. Segundo Castedls: "A indústria agrupa fases tec nicamente homogéneas c separa unjdades que pertencem à mes ma entidade juridica". Ou seja centraliza as funçōes técni cas c os estabelecimentos em lugares diferentes dos scus centros de decisōes. Nesta dialética centralização-descentralização, encerram-se grande parte das contradiçōes daquele tipo de urbanismo - trabalho, transporte e residên cia. Este parece-nos um fato irreversível. Este presidio "tripartido" coloca-se como o desafio para o urbanismo. Qualquer proposta de planejamento urbano que queira inserir soluçōes para o espaço de lazer e trabalho, tem que ser pensado no interior daquela 'trilogia'. Para Mumford a metrópole de hoje é o grande desafio:

\begin{abstract}
"Asi estaban las cosas a comienzos del siglo XX en lo referiente a los barrios; y el concepto de estos habia desaparecido tan por completo que en el primer intento que por entonces se presento de desafiar una ciudad completa y contuviera en si todo 10 necessario - tal el caso de Letchworth dos notables planeadores de ciudades, Raymond Unwin y Barry Park no hicieron esfuerzo alguno para delimitar ningun bairro y siquiera 10 sugeriron" (Mumford, p. 100).
\end{abstract}

Recolocando a posição de Tricart sobre a noçāo de bairro: "um sentimento coletivo idêntico ao que possui o camponês em relação à região em que vive", pode mos perceber que sua simples transposição para a compreensão de fenômeno do bairro no conjunto do espaço metropolitano, não somentë se torna insuficiente como tambëm inadequado. Não cabe aqui aprofundar as diferenças teōricas com - autor. Mas sim tentar perceber a evolução do fenômeno e tentar caracteriza-10 nos dias atuais, no mesmo tempo a- 
hrindo a possibjujdade de uma nova concejtuação.

Como jä apontamos em oturo momento do traba 1ho, O Bexiga pela sua origem naquele conjunto de chácaras que circundavam a cidade de São paulo no século Xlx e pelo grau de interação que teve com a cidade até as primeiras décadas do século $x x$, guardou bastante daquelas caracterís ticas apontadas por Renato da Silveira Mendes e Jean Tricart.

Toda nossa análise nos capítulos anteriores leva-nos neste momento, a tentar caracterizar a atual situação deste bairro no processo de metropolização pelo qual passou São Paulo. As novas relaçōes sociais nascidas de uma nova divisão social do trabalho redefiniu a posição do bairro no conjunto daquele espaço. Não seria possível continuar admitindo a continuidade das mesmas relações e configuração de uma mesma condição de identidade das pessoas com o lugar, após todas aquelas transformações jă ana lisadas anterioremente. Cabe-nos agora verificar o tipo de enquadramento do bairro ao novo espaço metropolitano. Sobre a questão das relaçōes de classes, do processo de estra tificação social com o lugar, Lewis with faz a seguinte anālise :

"Os grandes números são responsāveis pela variabilidade individual, pela relativa ausência de conhecimento pessoal intimo, pela segmentação das relaçōes humanas as quais são em grande parte anônimas e superficiais e transitórias e por características correlatas a densidade envolve diversificaçōes e especializações, a coindicência de contato físico estreito e relaçōes sociais distan tes, constrastes berrantes, um padrão complexo de segregação, a predominância do con 
trole socias formas, catrito acentuado entre fenómenos. A heteropenejdade tende a quebrar cstruturas sociais rigidas c a produzir maiores mobilidades, instabilidades e insegurança e a filiasão deindividuos a uma variedade de grupos sociais opostos e tan genciais com um alto grau de renovação dos seus componentes. 0 nexo pecuniário tende a a deslocar as relaçōes pessoais, e as insti tuições tendem a atender às necessidades das massas em vez dos individuos. 0 individuo, portanto, somente se torna eficaz agin do através de grupos organizados..." (With, p. 22).

No conjunto de teorizaçōes sobre o novo fenômeno urbano feito pelo autor, podemos pinçar vários elementos que nos permitirão compreender o papel dos bairros no interior das metrópoles.

Este surge como um fenômeno de exterioridade no conjunto das relações entre os individuos. A proximi dade física não passa mais a significar relaçōes estreitas de vizinhanças, contraditoriamente ela pode significar dis tanciamento social. Como já haviamos colocado a "nova cida de" e o "novo bairro" passaram a significar transitoriedade e segregação. 0 pecuniário não somente segrega um bairro em relação a outro, mas pessoas do mesmo bairro.

Enfim, cada vez mais o bairro vem se tornan do aquela instância política-administrativa já aventada no inicio do capitulo. A proximidade dos individuos coloca-se naquele nível de "atomização". As pessoas, quando se unem, - fazem por condições contingênciais que representariam aqui aquela aventada pelo autor acima mencionado, existem muito mais como algo transitório do que como um elo efeti- 
vo para consolidar estrejtas rejaçōes de vizinhança. Instân cias organizacionais que se encontram cm continuo processo de renovaçāo, resultantes da própria mobilidade imposta pelas condiçóes de trabalho, residencia e transporte. Sobre a natureza do bairro, Jorge Wilheim nos faz a seguinte colo cação:

"Hoje, São Paulo conta com cerca de 1360 bairros, vilas e jardins, tendo a maioria de les surgido após 1950 como resultado da imigração interna e de atividades de loteadores ... Inegavelmente, o bairro constitui hoje a unidade urbana, a representação mais legítima da espacialidade de sua população e não é por acaso que São Paulo conta com 900 "Sociedades de moradores", também conhecidas co mo "sociedade amigos do bairro", cuja territorialidade é facilmente reconhecida... 0 bairro corresponde à dimensão de território ideal para a reivindicação coletiva. Em território maior, na região administrativa, sur gem conflitos de prioridade entre um bairro e outro, em escala menor, na rua domiciliar, as reivindicaçōes esgotam-se rapidamente". (Wilheim, p. 64).

Mais uma vez percebemos, pois, que a noção de bairro estā restrita à dimensāo "atomizada" de instância de "mobilização" de massa.

4.1. Unidade e Diversidade

0 que é hoje o Bexiga? Um espaço dividido Bexiga, Bela Vista, Bixiga. Desde que, em 1912 o bairro pas sou a chamar-se Bela Vista, jā guardava diferenciação no seu interior. Na verdade a expressão Bela Vista representa- 
va a parte alta do hajro - topográfica cocialmente. Era - ajto da grota c suas imediaçócs no espigão da Av. Paulís ta. Diferenciava-se profundamente do piques e suas imediaçōes. Era neste que na verdade localizava-se propriamente - Bexiga. Enquanto identidade, já vimos-que sua população automaticamente excluia-se da parte "nobre", vendo como ou tra ārea, chegando mesmo a ser considerada por muitos como um outro bairro. O Bexiga estendia-se até as elevaçōes entre a rua 13 de Maio e rua dos Ingleses, cujo acesso, dava-se pela escadaria da rua Fortaleza. O Bexiga ocupou toda a baixada do antigo Ribeirão Bexiga, até a esplanada on de estão colocadas as cantinas da Rua Rui Barbosa e Treze de Maio, caindo depois para os fundos do "ribeirão Saracura".

A inserçāo do Bexiga na toponímia Bela Vista, não significou a integraçāo destas duas áreas distin tas na história e formas de uso. Isto nos leva a crer muito mais numa imposição política-administrativa do que uma preocupação de integração da vida comunitária das mesmas. O Bexiga nasceu como um "espaço pompeiano" e mantevese como tal por muito tempo. 0 outro foi o símbolo das novas relações formais que se consolidavam no interior da me trópole emergente.

Assim, o Bela Vista, enquanto bairro, parece-nos muito mais produto da intervenção administrativa do que a expressão histórica de uma criação de vida comunitária. Esta expressāo jā demonstrava uma divisão espacial dentro daqueles limites administrativos. 0 desuso da expressão Bexiga foi sendo lenta e gradual. Se de um lado a parte nobre, isolada do conjunto simbolizava a diferencia- 
ção de classes c a divisão do hajro, do outro lado, a assjmilação gradativa do "baixo" piques pelo "centro histórjco", divorciava esta parte tradicional do Bexiga do restan te do bairro. Podemos perceber que a sua evolução, enquanto uma unidade espacial caracterizada em todos os níveis pelo velho conceito de bairro, acabou marcando um processo de incorporação de novas áreas e retaliação de outras mais antigas. Isto deve ser considerado quando quisermos respon der à pergunta do que é o Bexiga hoje. Obviamente que ele não mais corresponde àquele espaço urbano existente na virada do século, tampouco pode ser considerado o mesmo da década de cinquenta, quando o Piques se foi desmembrando para se integrar ao "centro". Naquele conjunto de ele mentos simbōlicos que reforçam a noçāo de bairro, foi ocorrendo um processo contínuo de esvaziamento. Na verdade o Bela Vista, como expressão de um novo momento histórico, foi tomando o lugar do Bexiga.

O bairro da Bela Vista é hoje, no conjunto dos bairros metropolitanos, a esperança da superação daque la "trágica trilogia" para o trabalhador. Um bairro, que, na verdade, poderia ser chamado de - o bairro dus "novos andarilhos". Novos no sentido de que não devem ser confundidos com aqueles do passado, do espaço "pompeiano" do "ve 1ho Bexiga", onde rua, casa e trabalho significa um todo integrado, onde o homem podia sentir-se "inteiro". Para os novos moradores do Bela Vista estas ruas são tão estranhas como a paisagem daqueles usuários dos coletivos que passam mas não vêem o espaço percorrido, ou quando o vêem, não o vivenciam.

A fixação no bairro permitiu de uma certa forma resolver problemas de distância física, porém isto 
näo significou a "aderência" dos habjtantes ao espaço. Em lugar da policza da auto construção dos bairros periféri cos, a incerteza e miséria dos cortiços. O Bela Vista foi - lugar das habitações "comunitárias", hoje é o lugar das habitaçōes coletivas de baixa qualificação. E um bairro on de a transitoriedade da população tenderá a aumentar pela própria tendência revelada nas suas formas de uso do solo. Perdeu-se o "sentimento de localidade". Gradativamente vai sendo "assimilado" pelo CBD (Central Business District) e pela "Nova Paulista", de onde entram aquelas funções "modernizadoras".

Outra parte do bairro "revitaliza-se" naque le conjunto de atividades "turísticas". 0 restante comportando-se como um verdadeiro "quarto de despejo". Para alguns a possibilidade de acesso à "nova onda", aqueles "flats" que entram no pedaço; para outros a expectativa da expulsão. Aquele "sentimento de unidade quebrada" não se: limitou a uma quebra na escala humana dada pela verticalização. A "implosão", o sentimento de desmembramento daquela "antiga unidade" em "pedaços", segue um processo "irreversível" de mudanças de uso no seu espaço, buscando, cada vez mais, a construção de uma "nova unidade" no conjunto da metrópole. No interior deste "novo espaço" que se produz, aquelas funções de lazer e diversōes é que vão se integrando à metropole. E um "pedaço" do antigo bairro que estabelece a "nova relação", o restante é a plena transi toriedade. Estas funções nascidas da "revitalização de algumas tradiçōes; paradoxalmente, passaram a significar a prōpria negação de bairro como instância comunitária.

0 "novo bairro", que se formou no interior da metrópole, revelou-se cheio de contradiçōes enquanto 
satro que simboliza um centro funclonas de lazet e diveriócs, cada vez majs vê scus moradorcs, novos c antigos, dis tantes de poderem desfrutar destas funçōes. Um bairro que atrai pesşoas de outros lugares e não permite nem ao menos que sua população local tenha acesso a logradouros públi zos pois eles são aí inexistentes. O Bela Vista é hoje a expressão da fragmentação do homem urbano.

\subsubsection{Estrutura e morfologia urbana}

Partindo-se da noção que a cidade é a expressão de uma "escrita criada pela História sobre o terri tório", cabe-nos neste momento tentar ler e compreendê-la. Neste contexto procuraremos nos deter em nossa área de pesquisa, ou seja, o bairro da Bela Vista. Para tanto deli mitaremos aquilo que foi a base do nosso levantamento empí rico e argumento de todas as teorizaçōes feitas até agora.

Compreendido entre a Av. Brigadeiro Luiz A tonio, Av. Nove de Julho, Pça. da Bandeira e rua São Carlos do Pinhal, o bairro da Bela Vista guarda hoje, depois de todas aquelas transformaçōes, áreas com características de uso e relaçōes sociais que thes permitem uma sugestiva identidade no conjunto do bairro. Assim, conseguimos par tir para a segmentação das mesmas, nāo como mero exercício de "leitura deste espaço", mas para tentarmos encontrar a identidade deste bairro como um todo. Os segmentos identificados constituíram-se da seguinte forma: Os segmentos re presentados pelos corredores, que designamos como área A e os segumentos dos quarteirōes designados como ärea B. Tan to os primeiros como os segundos comportaram sub-divisões, (Fig. 10, 10A e 10B). 
USO DO SOLO NO BAIRRO DA BELA

VISTA POR SUB-UNIDADES

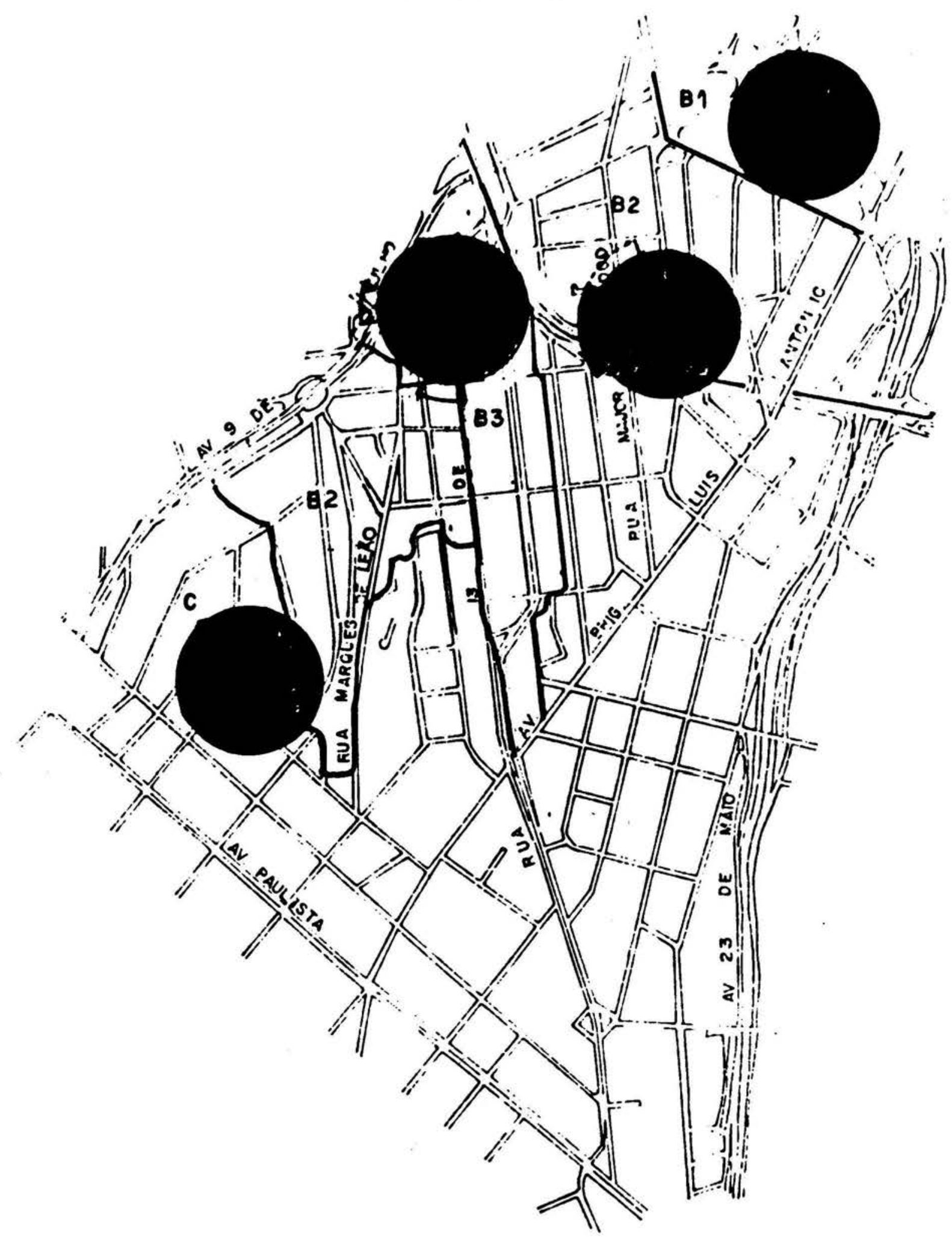

SUB-UNIDADE 81

Funçб̄o Rosidenciol

Sorviços

Comoreivo

SUB-UNIDADE BS

Fungto Rasidencial

Services

Comircio

Industrito

Sorviges Turiemo

Contines

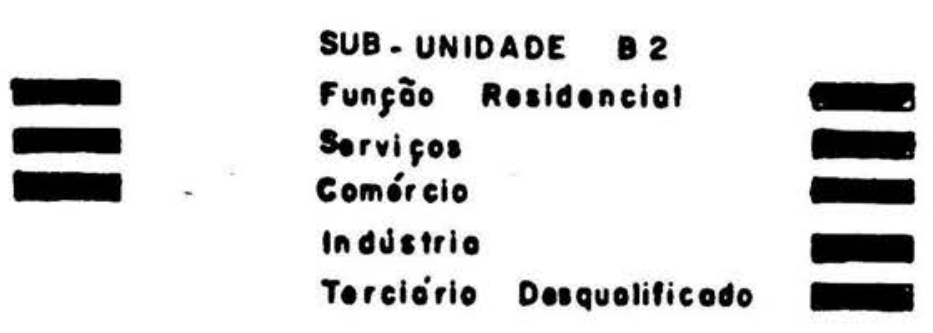

SUB-UniDADE C

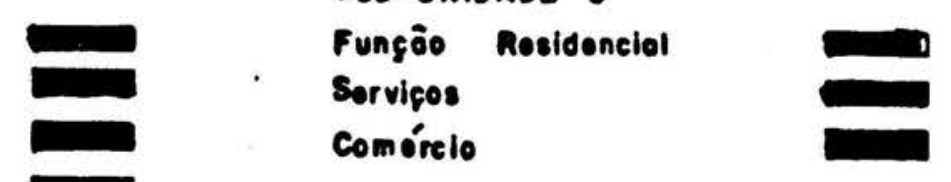




\section{USO DO SOLO NO BAIRRO DA}

\section{BELA VISTA}

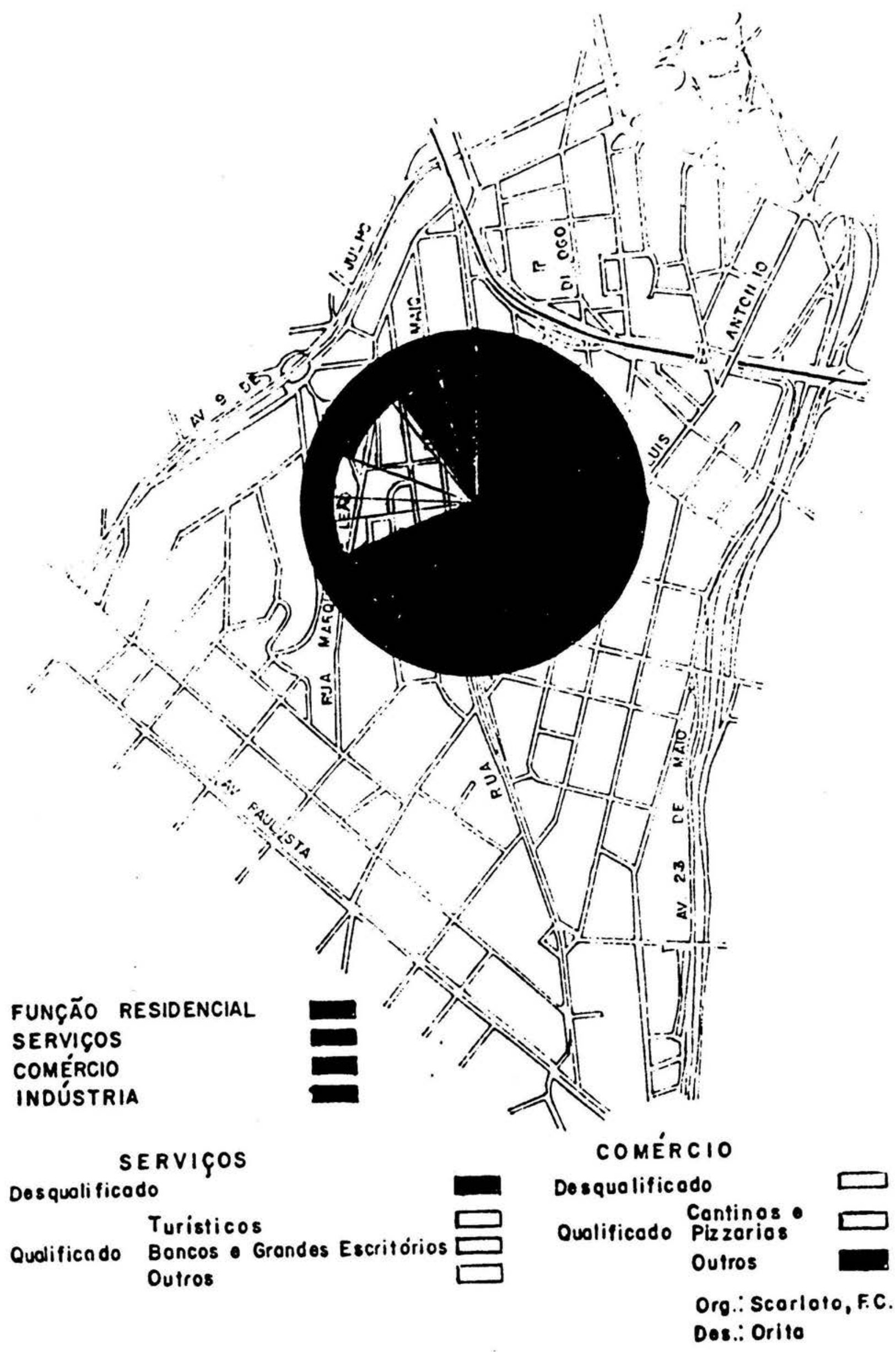


() corredor $A-1$, E representado pelo Anel de lstacionamento do lentro 1, também chamado de clevado Alcantara Machado, ou "minhocão". F. o grande simbolo da mutilação do bairro - o grande "muro de Berlim" do bairro. Dividiu e não conseguiu fixar atividades ao longo do seu percurso. Este fato está ligado à forma como este corta o espaço no lugar. Apresenta-se como uma massa compacta de concreto, em grande parte suspensa. Apesar de permitir a gumas ligaçōes com o interior da Bela Vista, o grosso do seu fluxo de transporte - na maioria de automóveis, não tem o bairro como destino. Como falamos, ele é o monumento do "Bexiga Ano Zero". E uma daquelas grandes vias expressas construídas para o automóvel. Podemos configurá10 como uma "via externa". 0 "externo" não deve ser enten dido somente no plano físico-territorial, mas no simbolís mo para o bairro e pelo fato de não "criar raízes" com o interior do mesmo.

0 corredor $\mathrm{A}-2$ é representado pela Av.Nove de Julho. Tendo nascida como uma via de ligação do "cen tro" da cidade com os novos bairros jardins na zona sul, apesar disto sempre foi assumida como uma via do Bexiga, fosse nas representaçōes simbólicas que a população do bairro guardou na memória do velho bairro, como pela presença de muitos moradores que mantinham, até bem pouco tempo, relaçōes estreitas com o mesmo. Hoje, na verdade. ela é mais um daqueles corredores que passam pelo bairro. Gradativamente foi perdendo sua identidade com o mesmo. $\underline{0}$ cupado intensamente por construçōes verticais, na sua maior parte por apartamentos residenciais de trabalhado res que poderiam ser classificados como pertencente à cha mada "classe média baixa". 
Na sua porção mals próxima da p̧̧a. da kandeira, além da presença dos apartamentos residenciais nota-sc uma concentração de prédios destinados a escritórios e instituiçōes públjcas. Segundo os números estatísticos por nós registrados para este corredor, conseguimos apontar 61,98 do total das ocorrências para o uso residen cial, sendo que somente 10,28 destas residencias eram representadas por antigas casas. Nas proximidades daquela pça. onde existiam alguns terrenos vazios, estão sendo construidos grandes prédios com apartamentos de pequenas unidades, tipo flat. O reduzido comércio aí localizado é representado na sua maior parte por pequenos bares e lanchonetes. Somente prōximo à pça. Quatorze Bis é que apare ce um pequeno conjunto de pequenas lojas e um pequeno supermercado.

A Av. Nove de Julho surgiu na década de quarenta quando o prefeito Prestes Maia elaborou o "Plano $Y^{\prime \prime}$. O pouco comércio e a inexistência de serviços que pos sam atrair a populaçāo do bairro para o mesmo faz deste espaço um elemento quase "externo" ao Bela Vista. A pça. Quatorze Bis é ainda um dos poucos lugares que nos permite perceber seus vínculos com o bairro. Nela existe um grande equipamento urbano servindo de parada de ônibus com o nome Vai-Vai; fica localizado em frente à quadra de ensaios da referida escola. Em entrevistas feitas com moradores dos prédios aí localizados, constatamos que a sua grande maioria não trabalha no bairro e usa muito pouco dos serviços do mesmo.

Outro corredor é $\circ A-3$, representado pela rua Maria Paulor Este, apesar de ter representado uma 1i- 
gaçäo mais cestreita com o hajro sendo um Jugat onde se po de perceber pelas imediaçóes a presença de antigos casarōes, também transformou-se num ponto de passagem dentro do bairro. Faz parte da via Perimetral criada por prestes Maia no conjunto daquele grande projeto de expansão viária de São paulo nos anos quarenta. Hoje representa uma área bem caracterizada como "assimilada pelo CBD". Presencia a implantação de projetos de construção de grandes edifícios para escritórios.

Tanto a Av. Nove de Julho como a rua Maria Paula foram por nós classificadas como "corredores interme diārios", visto a natureza de transição que representam no processo histórico de ocupçāo do bairro, e o distanciamento contínuo que representam para o uso da população do bairro como um todo.

Enquanto os corredores $\underline{A-1}, \underline{A-2}, \underline{A-3}$ foram designados como corredores "externos" e "Intermediārios" a av. Brigadeiro Luiz Antonio - trecho compreendido entre a São Carlos do Pinhal e rua Maria Paula e a rua Rui Barbosa foram como A-4, ou corredores "internos". Esta designação deve-se ao fato dos mesmos representarem formas de uso for temente ligadas com o bairro, e representarem no conjunto das lembranças dos antigos moradores, ligaçōes com o passado.

A "Nova Rui Barbcsa", herdeira de uma tradi cional rua do Bexiga, mesmo depois de ter se transformado no grande símbolo de "mutilação urbanística", acabou se reintegrando ao "Novo Bexiga". E ao longo desta via que se estabeleceram uma parte significativa das atividades que caracterizam o bairro - teatros, casas de shows, cant $\underline{i}$ nas, casas de música-bar. Mesmo tendo sido construída como 


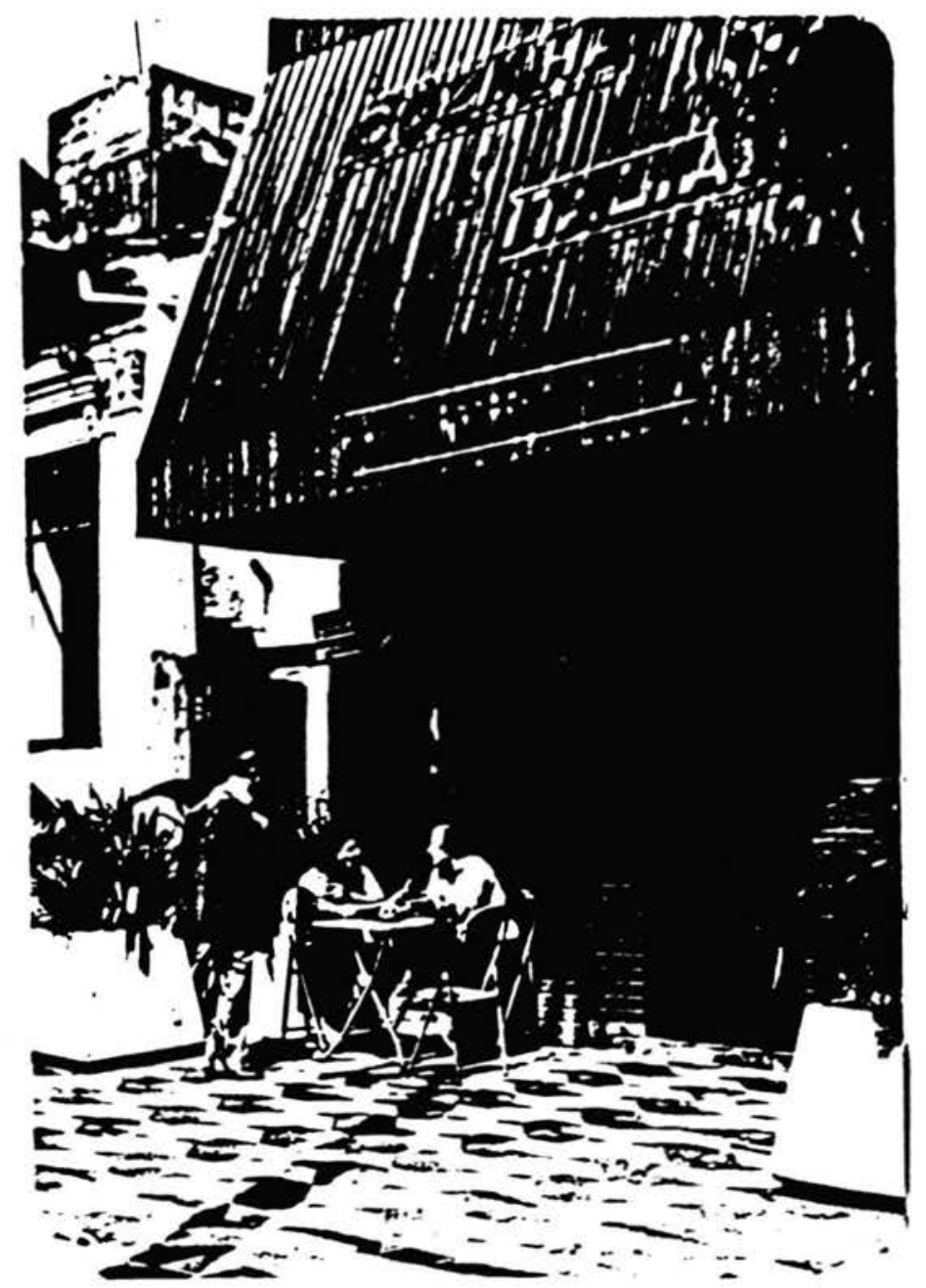

Foto 14: Cantina localizada na "nova rua Rui Barbosa". Apös o período de reurbanização esta via foi ocupada pelas atividades "revi talizadoras". Esta è uma entre outras da "nova" rua.

(Ano: 1988) 
uma via de ligação entre aquele "Anes de listacjonamento Cen tro 1 " c as vias de ligação da zona sul, cortando o bairro acabou servindo como elemento de fixação daquelas ativida des ao longo do seu eixo, tornando, assim, um lugar repre sentativo das ativìdades do mesmo.

Muitos dos eventos realizados com a finalida de de reativar a lembrança das suas tradições do bairro, encontram-se neste trecho; varais com roupas penduradas", mais uma vez colocados como representação simbölica do "italia nismo" do bairro, tentando fazê-1o a "Nápoles Paulistana" ; a festa de aniversắrio de São Paulo realizada no dia 25/ 01/88, com o "grande bolo de confraternização" procurou-se mostrar o "espirito de comunidade do bairro. Este bolo foi feito pelas organizações representativas das lideranças do Bexiga. A festa acabou terminando em pandemônio, numa grande algazarra, depredação do mesmo e uma bagunça generalizada. Mais do que um fato isolado - um "vire-se quem puder"re velou-nos uma situação "trágico-cômica" da fragilidade das tentativas de se querer ressuscitar relações comunitárias que dificilmente cabem hoje no bairro, pelo menos nos moldes do passado. "As mesas e cadeiras" não têm mais lugar no "Bixiga".

A av. Brigadeiro Luiz Antonio, teve sua evolução muito ligada à história do bairro. O que sobrou dos antigos casarões que dão continuidade às ruas Conselheiro Ramalho, trecho da rua Rui Barbosa, na sua parte não mutila da, formando um tecido contínuo, permite-nos perceber uma integração com as áreas adjacentes do bairro. As atividades que caracterizam o mesmo, aí também sāo encontradas: pizzarias, teatros, casas de trocas de objetos antigos, etc. Re- 
presenta o lugar onde cstá concentrado o tercjäjo que aten de a população, como bancos, Caixa liconómica, lojas de roupas, Casas de Optica e revelação de filmes, lojas de eletrodomésticos, casas de peças e acessórios para carros, consór cios etc.

A Av. Brigadeiro, apesar de apresentar uma importante concentraçāo do terciário, continua abrigando uma importante função residencial: 30,98 das ocorrências re gistradas no uso dos lotes está representada por esta função. Pouco mais da metade da população que aí habita $(53,18)$ mora nos casarōes já referidos. O terciārio que ocu pa ai 68,68 dos lotes está assim representado: as ativida des de comérciótacima referido ocupam 27,58 dos lotes, os escritōrios, bancos e caixas econômicas ocupam 17,48. 0 restante refere-se a atividades de comércio e serviços mais dispersos.

Estas atividades têm fortes ligaçōes com uma significativa população cativa do bairro. Desde o tempo do bonde "Bexiga", depois Bela Vista, que a percorreu fazendo a ligação desta via com seu interior, continua como lembran ça do antigo bairro.

Se os corredores se impōem morfologicamente na estrutura urbana pela sua "linearidade" como um elemento "polarizador" e diferenciado, fora deles a possibilidade de se encontrar um lugar com identidade estará ligada à concen traçāo de atividades entre-si no interior daqueles quarteirōes. Será na continuidade dos usos - no nível da dispersão e concentração existente no conjunto dos mesmos, que podere mos perceber aquela identidade. Os quarteirōes delimitados por suas respectivas ruas serviram de elementos identificadores 
de ârcas, onde cada uma se caracterizou come uma unjade da ferenciada da outra, com jecntjade pópria.

Intre as mesmas consegujmos jdentificat as seguintes: Área $\underline{B}$, constituindo-se naquilo que chamaremos de "Unịdade do Núcleo Histórico". A outra é a Área $\underline{C}$, que chamaremos de "Unidade Nova", corresponde àquela área que fica além da encosta da rúa 13 de Maio ou, mais precisamente, ao Morro dos Ingleses (alto da grota) e àdjacências do espigão da Av. Paulista. A Unidade correspondente à Área B apresenta algumas sub-unidades que passaremos a descrever à partir de agora.

A área Bl, de antiga ocupação, foi assimilada pelo CBD. Esta área pelo grau de concentração e tipo de terciário que nela acabou prevalecendo, desmembrou-se das caracteristicas originais do bairro, sobrando muito pouco do que fora. Era a parte do antigo Piques. Nela encontramos uma "relíquia histórica" da antiga ocupação, a Vila Noschese com suas casas "operárias" e o que sobrou da antiga indústria ai localizada. Isto dentro de uma área que correspon de hoje àquele CBD. Patrimônio histórico, podemos afirmar, ser único testemunho de uma antiga forma de ocupação do bairro, num lugar tão próximo ao centro. Esta sub-unidade da Área B, está hoje ocupada na sua maior parte pelo setor terciário. Nela estão localizadas importantes instituições públicas como a Assembléia Legislativa Municipal e a Emurb (Empresa Municipal de Urbanização). As ocorrências registra das nas formas de uso dos lotes indicaram ai, em relação ao total da ārea de pesquisa os índices mais baixos para a fun çāo residencial: 31,08. O terciārio é nitidamente dominante: - setor de serviços é encontrado em 49,38 dos lotes e o comércio em 20,18. Esta sub-unidade vem revelando a tendência 


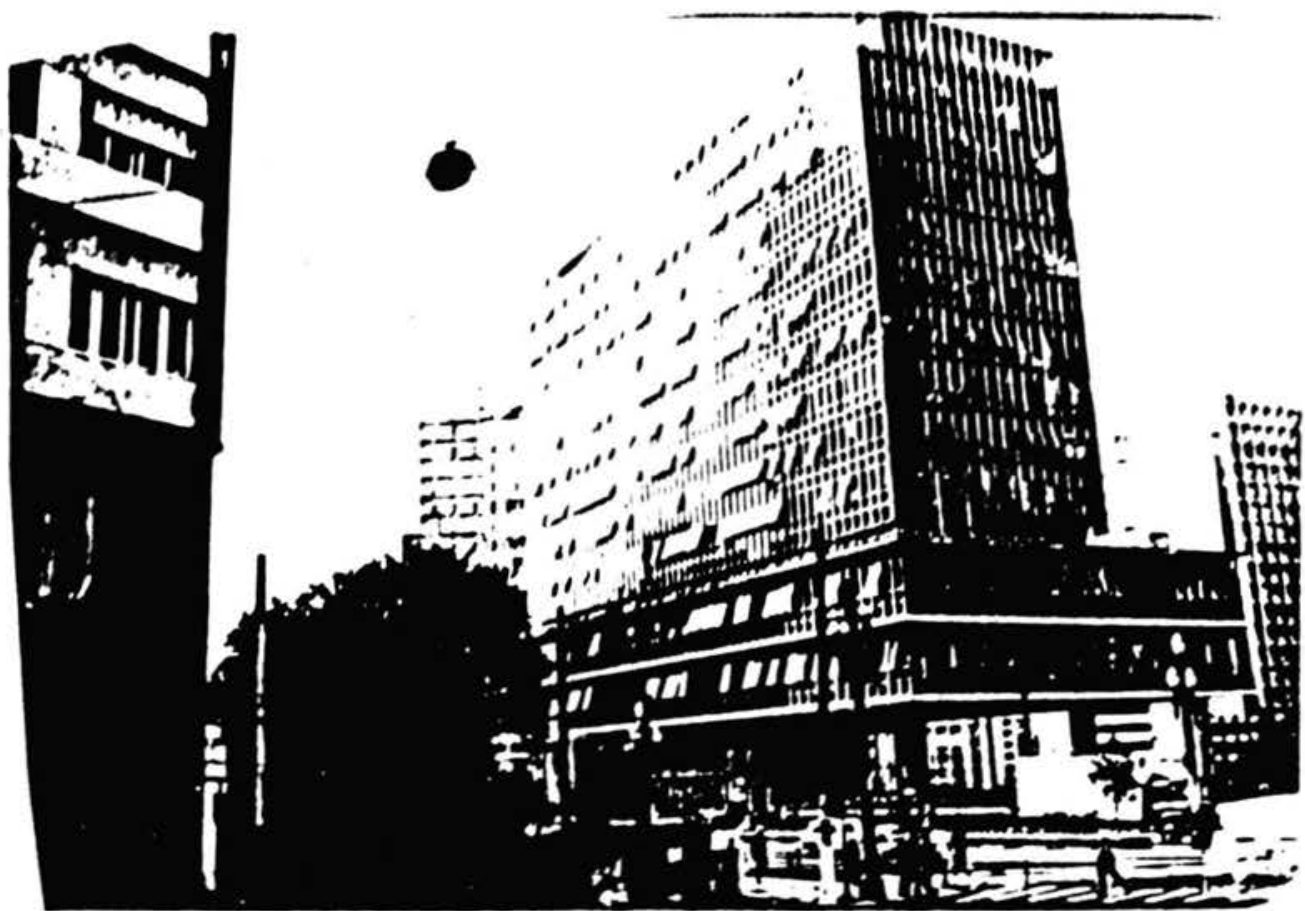

Foto 15: Rua Santo Amaro. Ao fundo a rua Jacareí e a Câmara Municipal de São Paulo. (Ano: 1988)

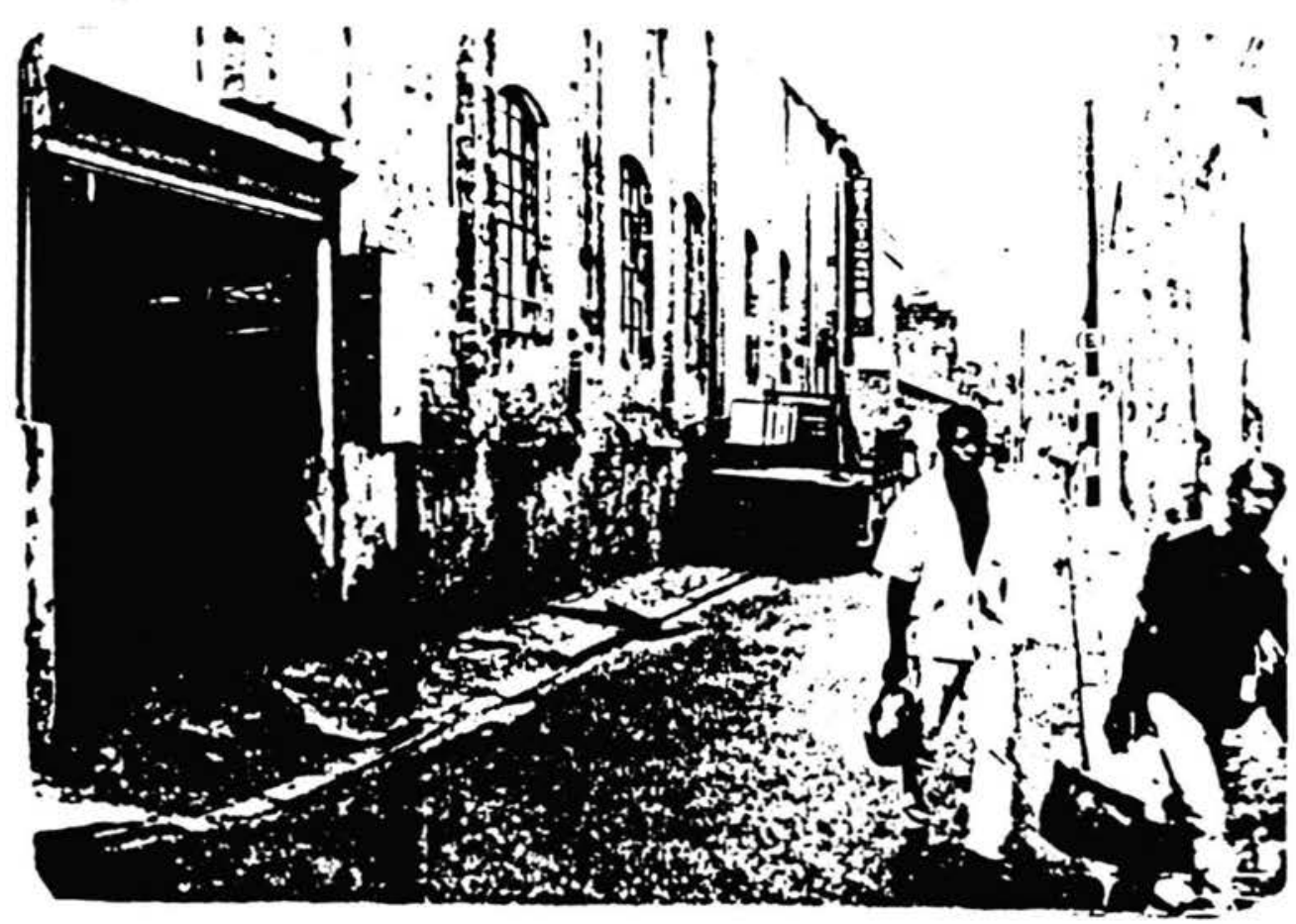

Foto 16: Galpāo de uma antiga indüstria localizada na travessa Nosche se (travessa da rua Santo Amaro). Testemunho de uma forma de ocupação do antigo Piques no início do século. (Ano: 1988) 


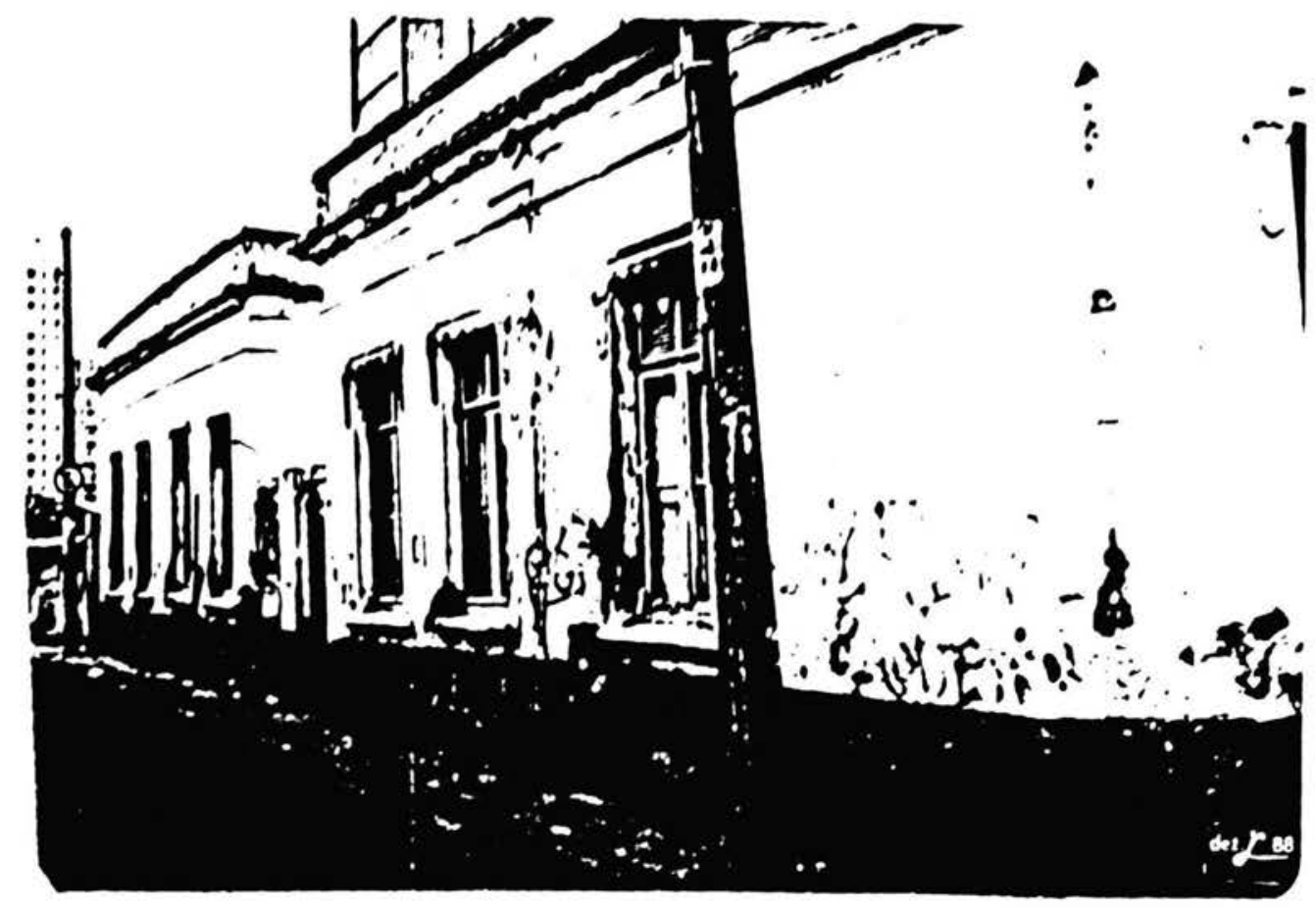

Foto 17: Casario localizado na travessa Noschese, pröximo ao prédio da antiga indūstria. (Ano: 1988)

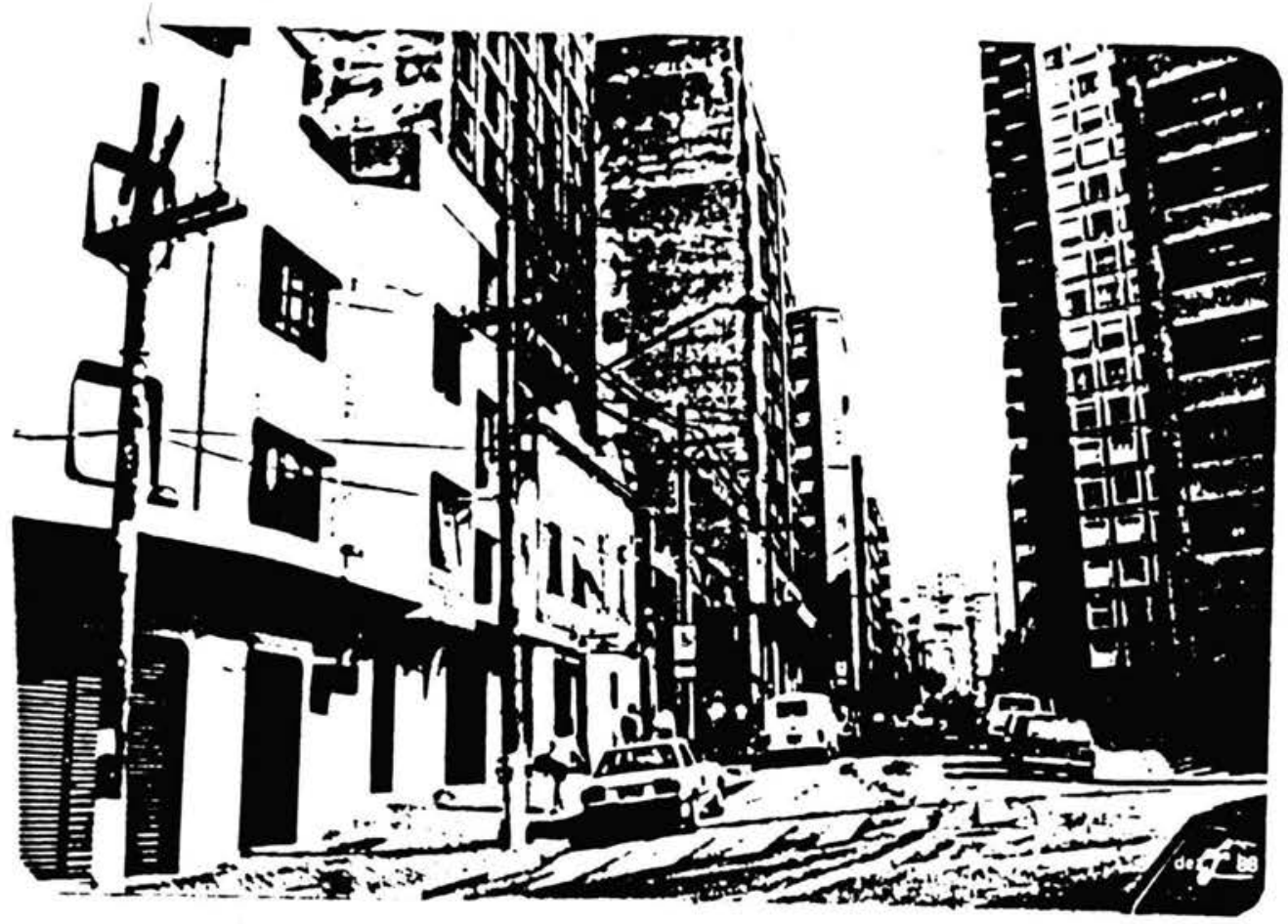

Foto 18: Rua Genebra esquina com a Rua Maria Paula. Testemunho de três períodos de ocupação. 0 casario do início do século, o prédio de apartamentos (de luxo) da década de 50 e o novo prédio pa ra escritörios (plano de fundo da foto). (Ano: 1988) 
de implantação de grandes projetos para prédios de escritó rjos, inclusjve providos com muitas vagas para automóve is no scu interjor. Este fato é significativo quando lembra mos que um dos obstáculos apresentados pelo "velho centro" para continuat abrigando a expansão do terciário, era a inadequação daqueles prédios ao automóvel. Enfim, a presen ça da vila Noschese e de alguns casarōes nas adjacências são as únicas lembranças do "antigo Piques".

$A \underline{B 2}$, também contida no interior do "velho Bexiga", caracteriza-se pela predominância da função residencial e pela forma difusa no uso do solo pelas ativida des terciārias e secundárias. Em termo de extensão é aquela que apresenta a maior área ocupada. Estende-se pelos quarteirões a leste da rua Rui Barboza até a av. Brigadeiro Luiz Antonio e rua Maria Paula e a oeste até a av. Nove de Julho, confinando no fundo da região da grota. 64,48dos lotes é ocupado por residências com grande concentração de cortiços e edifícios com baixas condiçōes de conservação .

E uma ärea com grandes contrastes de escala entre as formas de construçōes - velhos casarões perdidos no interior de edifícios que revelam aquela tendência ao adensamento que ocorre no interior do bairro. Podemos observar que a verticalização ocorre nas imedịaçōes dos gran des corredores, principalmente no ângulo formado pela av. Brigadeiro e rua Maria Paula. Os casarōes estāo mais concentrados em direção à porção oeste, isto é, em direção ao fundo da grota. E uma ärea que nos revela uma forma difusa e caótica no uso do solo, onde a "deterioração" física das construçōes e as formas de habitação precárias são muito sentidas. Os serviços e o comércio ocupam aí, respectiva mente: 16,88 e 13,88 dos lotes. E uma área de maior presen 


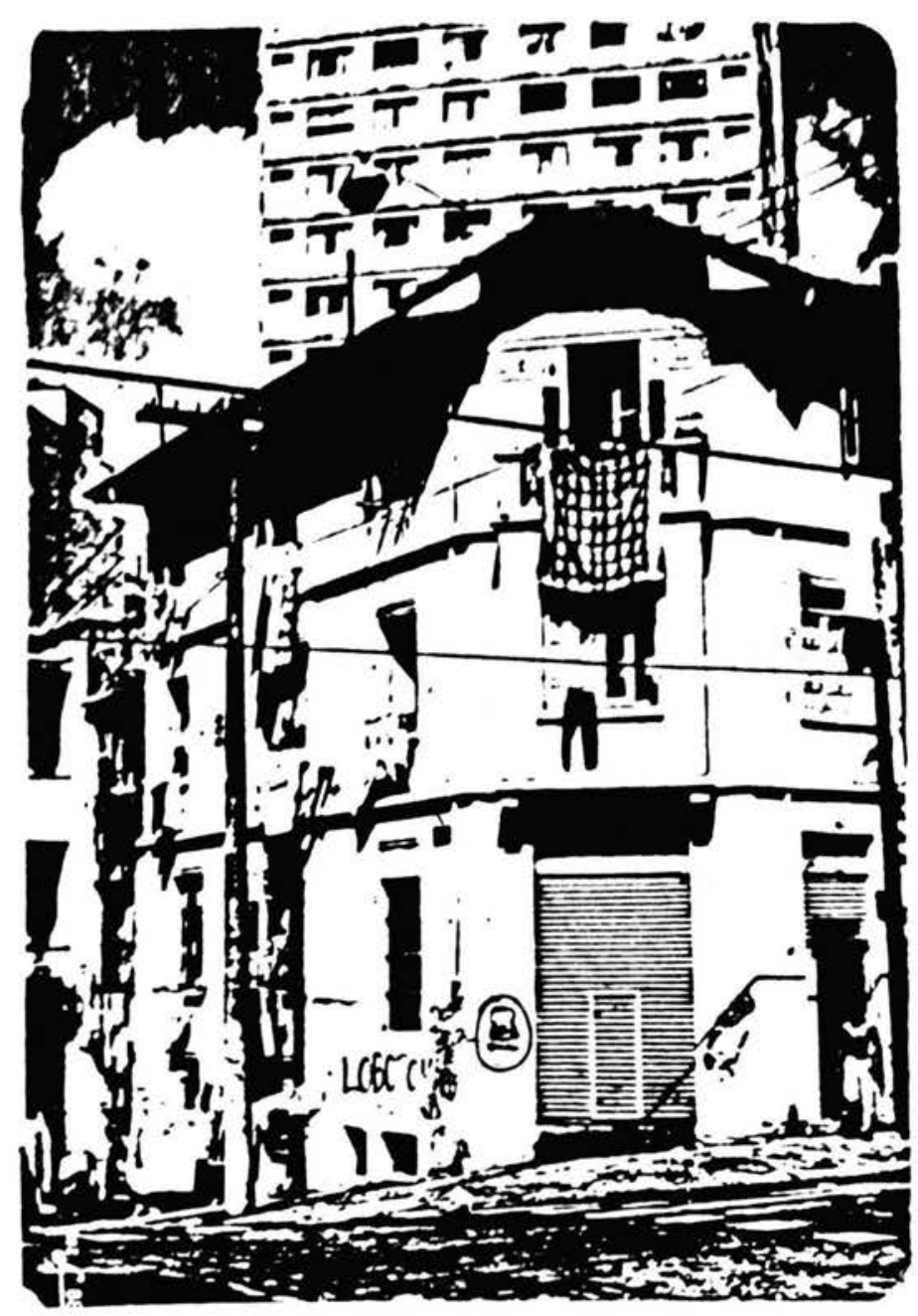

Foto 19: Cortlço localizado em um antigo casarão na esquina da rua fotale za e Conselheiro Ramá Iho, data aproximada, década de 20 .

(Ano: 1988)

Foto 20: Cortiço localizado na rua Almirante Marques Leão - parte baixa da Grota. (Ano: 1988) 
ça do setor secundário no conjunto do bajrro: 4,28 dos 10 tes da sub-unidade $\underline{22}$ é ocupado por indústrias. por sua vez, mais da metade do seu terciário (que ocupa nela 30,68 dos lotes) pade ser considerada como um terciário informal "desqualificado".

Se a caracteristica básica desta área é a não presença de um terciário que apresente alguma forma de concentração, e a quast inexistência das atividades "revitalizadoras", deve-se destacar uma "mancha histórica" no interior desta sub-unidade: a área do TBC (Teatro Brasile ro de Comédia) e adjacências, onde aparecem de forma muito tênue algumas daquelas atividdes "revitalizadoras".

Como jā apontamos, é uma sub-unidade marcada pela função residencial. Mais do que uma expressão numé rica, podemos afirmar que esta ārea guarda algumas "relí quias urbanas" - o conjunto de casas geminadas em antigas ruas estreitas, preservadas dos grandes fluxos de automó veis. Constituem-se em verdadeiros "refúgios", como lembranças de um tipo de vida comunitária. A Vila Cacilda em frente ao $T B C$, pequena rua sem saida, revelou-se, na pesquisa com, seus moradores, um reduto desta vida comunitária. Outro é a Vila Antunes, ponto de ligação entre a rua Forta lexa e a rua Rui Barboza. Rua estreita, também isolada do trāfego, guarda forte lembrança do "velho Bexiga". Podería mos mesmo afirmar ser um dos seus mais legitimos redutos do passado.

Além destas, foi-nos possível identificar a existência de "ruas comunitárias" naquele conjunto de casas geminadas, mais marcantes enquanto unidades arquitetônicas, porém com menores vestígios daquele tipo de vida co 


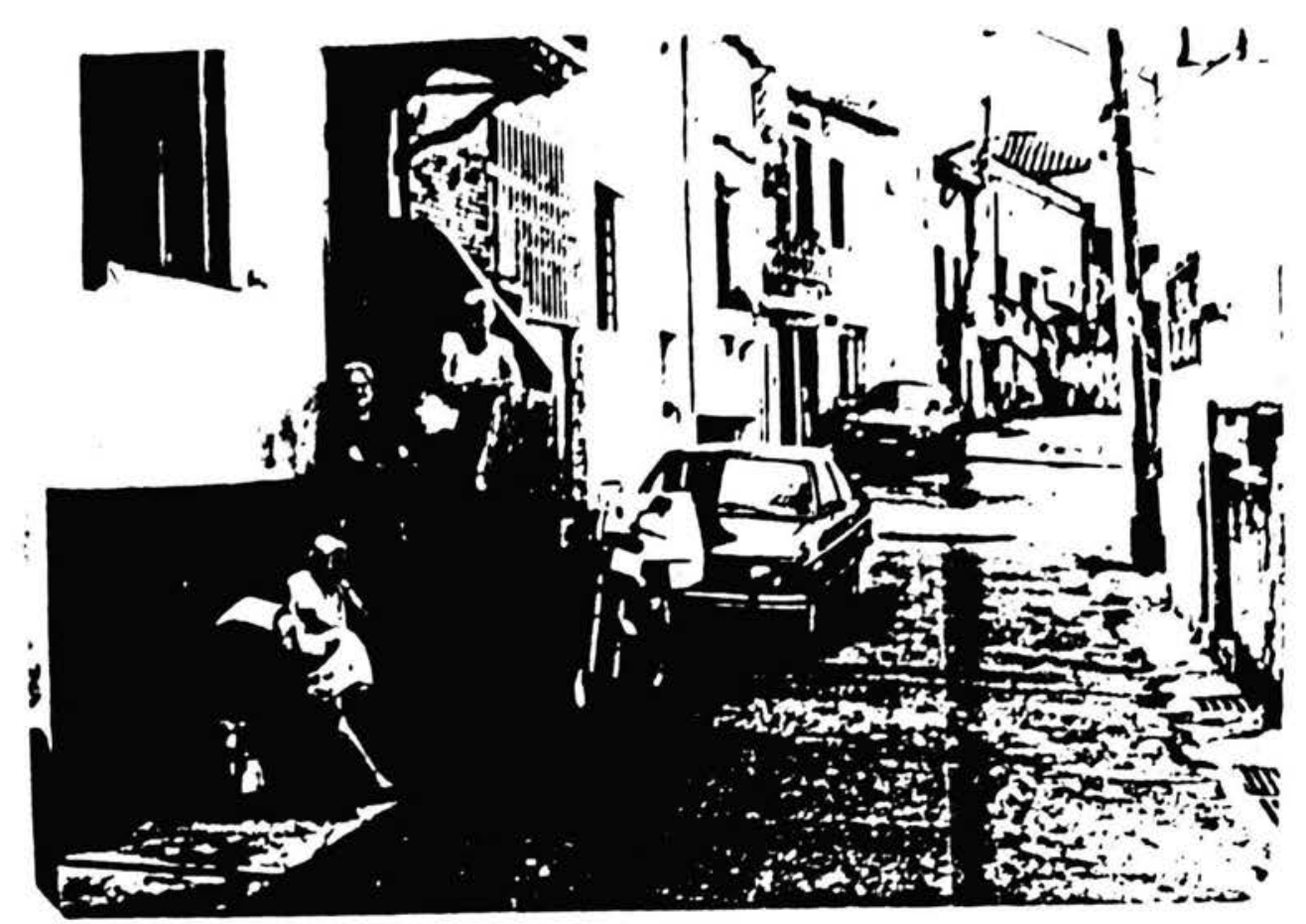

Foto 21: Vila Antunes. A sobrevivência de uma rua comunitäria. (Ano: 1988)

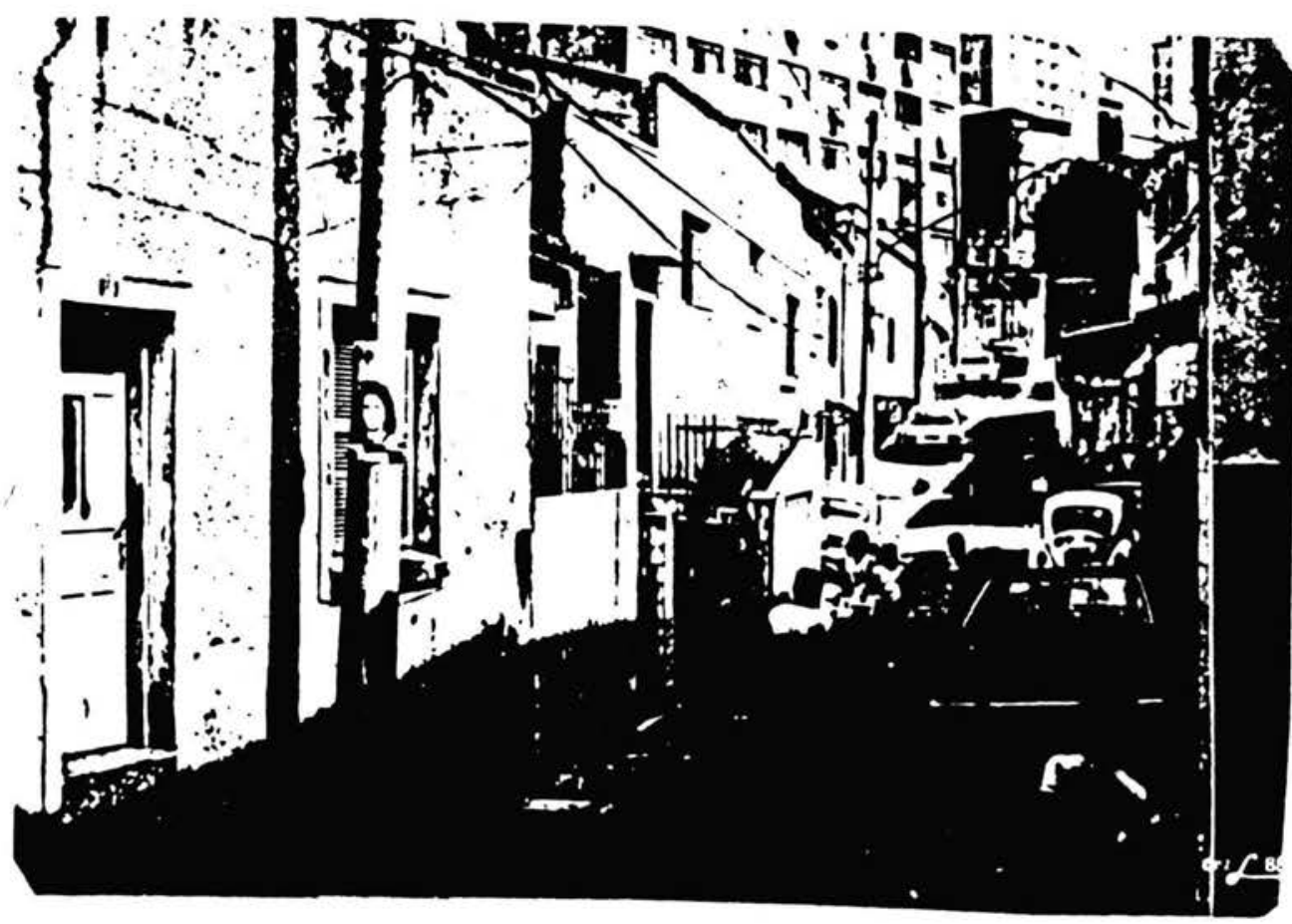

Foto 22: Vila Anturies. (Ano: 1988) 
munitaria, a exemplo: o Jardim Francisco Matcos (travessa da rua da Abolição), rua Nestor lsteve vatividade, entre a rua Abolição e rua Japurá e a Travessa do Bixiga. Lstas duas ültimas localizadas nas encostas do antigo "Ribeirão Bexiga". Para o lado da grota, temos a rua Velozo Guerra que adaptada às enconstas ingrimes da grota, tanto pelo relevo como pela natureza estreita da rua, permaneceu iso lada dos fluxos de automóveis. E bom lembrar, mais uma vez, a existência da antiga Vila São José, na rua Rui Bar boza, hoje demolida. Assim, como esta, este parece ser - destino das demais. A entrada dos novos edifícios de pe quenos apartamentos - os flats, nesta sub-unidade é uma das características mais notadas como tendência. Do total de lotes vazios registrados na pesquisa, 708 foram 10 calizados na região da grota.

Olhando-se no seu conjunto, a $\underline{B 2}$, poderia ser sub-dividiva, ainda, da seguinte forma: a parte leste da rua Rui Barbosa e 13 de Maio, com uma densidade ocupacional maior e mais verticalizada e maior número de cortí ços e a outra, a oeste daqueles dois eixos, com uma menor densidade e circulação.

No seu conjunto a $\underline{B 2}$, revela-nos na sua porção à leste dos eixos da rua Rui Barbosa e 13 de Maio uma maior densidade de ocupação e circulação em relação àquela localizada a oeste dos dois eixos em direção à parte mais acidentada do bairro, a regiāo da grota. Este fato acaba permitindo-nos perceber uma certa superpo sição entre a B2 e $\underline{B 3}$. Esta última, enquanto uma sub-unidade do "velho Bexiga" que caracterizamos como uma área "revitalizada" dentro do mesmo, acabou se definindo na verdade, como uma "parcela de espaço" com profundas inte- 


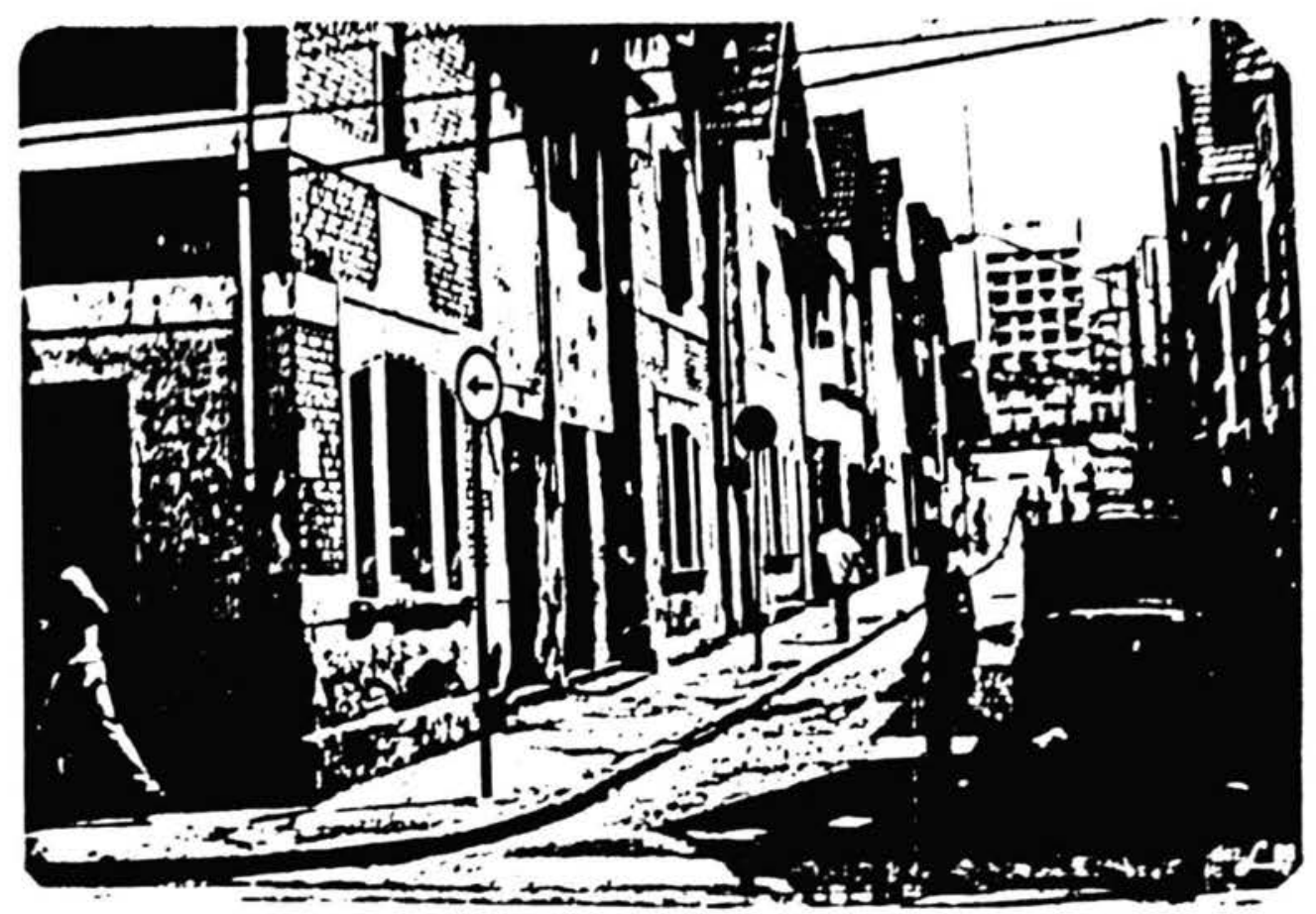

Foto 23: Conjunto de casas geminadas - Jardim Heloísa. Observe-se no plano de fundo o elevado do anel de estacionamento do Centro 1. (Ano: 1988)

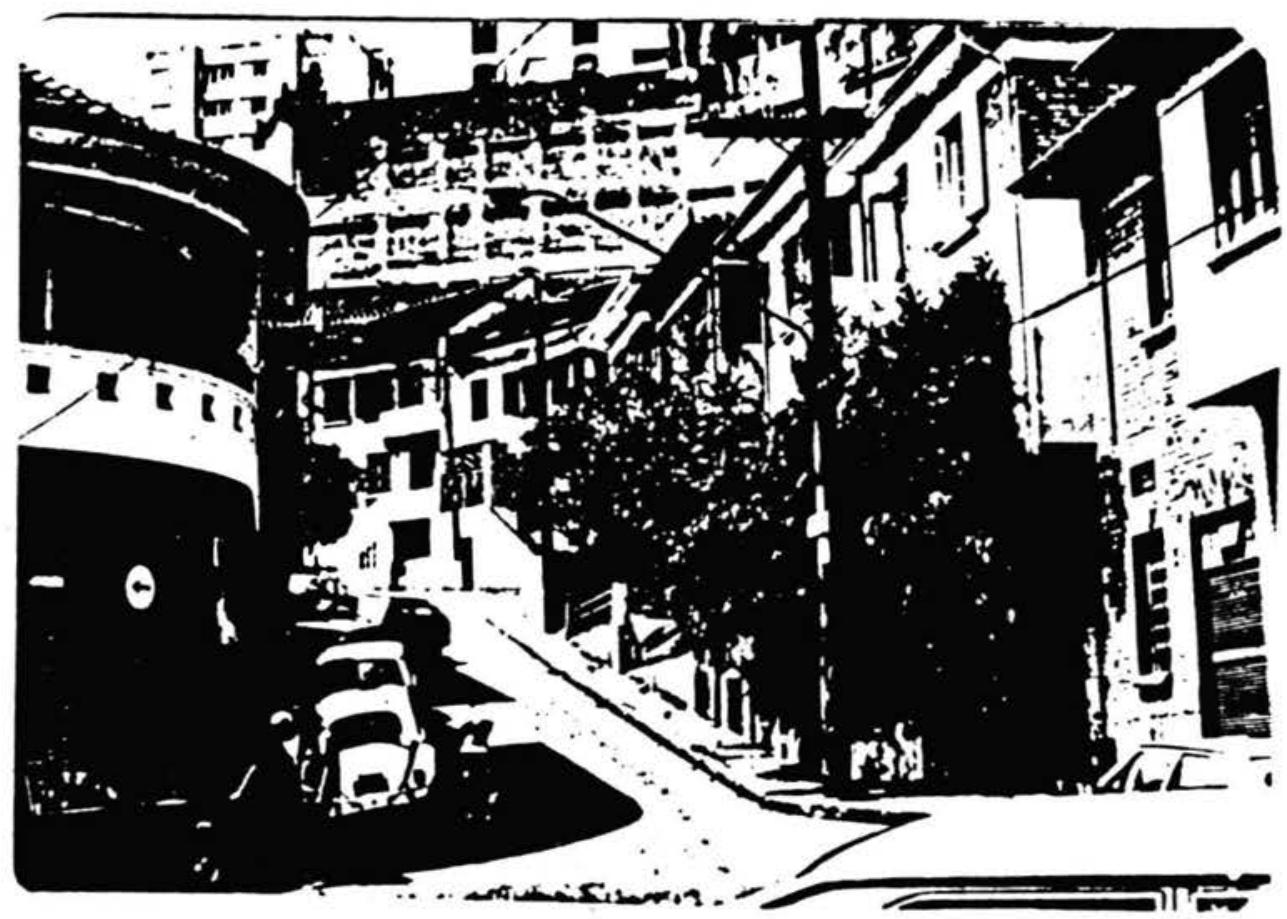

Foto 24: Rua Veloso Guerra localizada nas encostas ingremes do Morro dos Ingleses. Rua onde a vida comunitäria ainda ë preservada. (Ano: 1988) 
raçōes com a $\underline{\text { Z2 }}$, porém, diferenciando-se pela maneira c in tensjdade come abjogu as novas at jvidades.

A $\underline{B 3}$, área por nós denominada de "revitalizada", é aquela que passou a ser o "símbolo" do "Novo Bexí ga". Seus limites estão compreendidos nos dois eixos - 13 de Maio e Rui Barbosa e nas adjacências com a rua Sto. Antonio, onde-esta encontra-se com a 13 de Maio. Podemos afirmar que as atividades caracterizadoras da "revitaliza ção" estão alinhadas ao longo destas vias, raramente extra vasando para suas transversais. Estes dois eixos, polariza dores do "novo espaço", têm seus limites na Av. Brigadeiro Luiz Antonio, bifurcação da rua Sto. Antonio e rua 13 de Maio. Esta área sempre representou um papel destacado ao culto do tradicionalismo do bairro. E onde está localizada a Igreja, onde esteve localizado o antigo cine-teatro Espé ria, e lugar de realizaçāo, desde seu início, da festa da quermesse. E uma das áreas que ficou mais preservada da verticalizaçāo.

0 casario permanece de forma mais compacta no interior da B3. Somente 13,78 das suas consttruçōes foram registradas como sendo do tipo vertical, assim mesmo, com edifícios de poucos andares, raramente ultrapassam a oito. Aquela unidade de escala conseguiu manter-se, mais próxima daquilo que fora o bairro. Este fato, associado às novas atividades que se estabeleceram nestas antigas construçōes, serviu para fortalecer este pedaço do espaço como - "novo símbolo" do "Bexiga".

Tanto na B1, como na B2, seja na paisagem como nas formas de uso, a tradiçāo parece jā ter abandonado o lugar. E o caso mais explícito da B1. Quanto a B2, 
quando esta aparece, representa-nos mujto majs uma tradicão cm "desintegraçào" do que algo possível de ser mantido.A 8, apresenta-se como um segmento onde conseguimos sentir uma tentativa de "ressurgimento" daquilo que fora no passa do. Pelo que representou historicamente, é hoje, um lugar onde este "ressurgimento" invoca-nos a uma reflexão mais profunda entre o real e o imaginário no interior do "transe" pelo qual o bairro passa.

E na $B 3$ que sentimos mais de perte a superposição do Bela Vista do Bexiga e do Bixiga como produto do imaginário e da mídia. Do ponto de vista de um obser vador que vê o bairro como mercadoria de consumo, este aca ba resumindo-se a este núcleo "revitalizado" pelas cantinas e casas de diversões.

0 nível de concentração destas atividades no interior desta sub-unidade garante-1he a imagem que é passada pela mídia e seus consumidores. Do total de cantinas e pizzarias, fora outros tipos de restaurantes que foram identificados, 96,08 encontram-se dentro desta área. Quanto às casas de diversōes - casas de show, música e bar, cine-clube, teatros - ela representa 88,08, E bom lembrar que, enquanto estas casas de diversões estão mais disper sas no interior da $B 3$, as cantinas encontram-se mais con centradas, principalmente na parte próxima da Igreja entre a rua Conselheiro Carrão e a parte superior da de Maio.

Para compreendermos a consolidaçāo destas $\underline{\text { a }}$ tividades da B3 no interior do bairro e mesmo no conjunto da regiāo metropolitana, devemos invocar algumas transformações ocorridas com esta ūltima. No passado estas ati- 
219

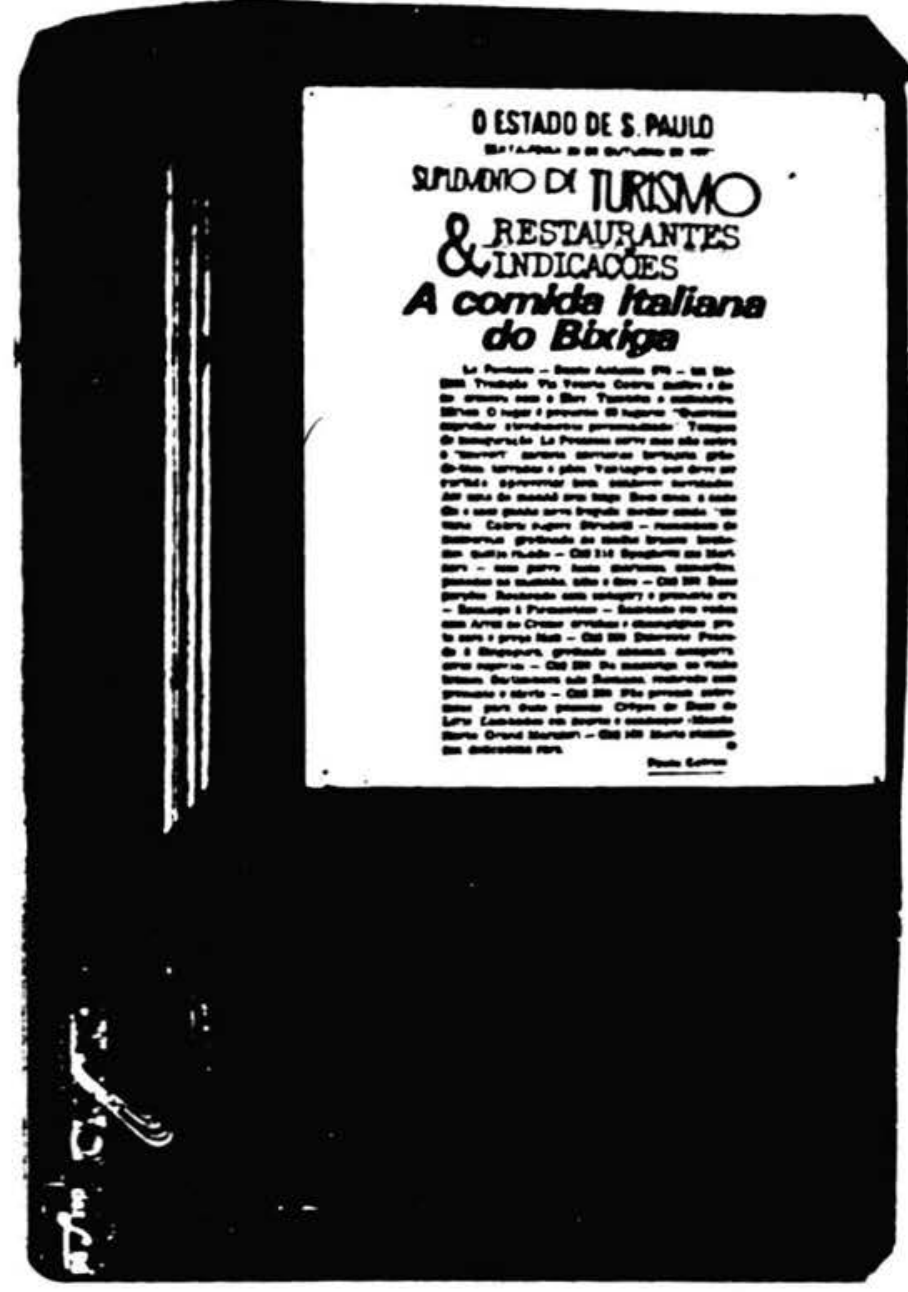

Foto 25: A mídia e o "Bixiga". Porta de um restaurante localizado na ärea B3. (Ano: 1988) 


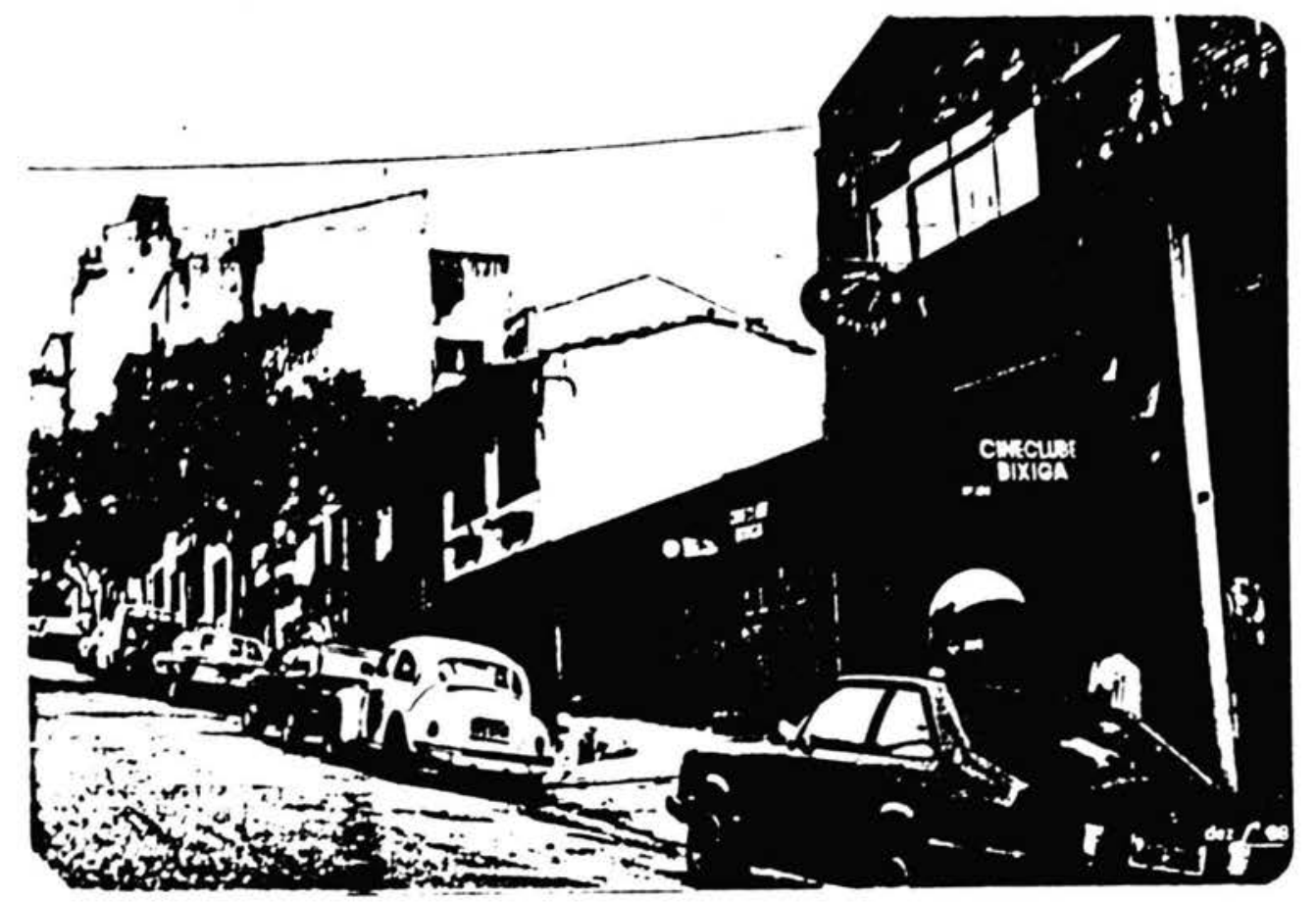

Foto 26: Rua Treze de Maio. Trecho localizado entre a rua Santo Antonio e a rua Manuel Dutra. Area da B3 de grande concentração daquelas casas de diversão noturna. As fachadas destas casas foram descaracterizadas. (Ano: 1988)

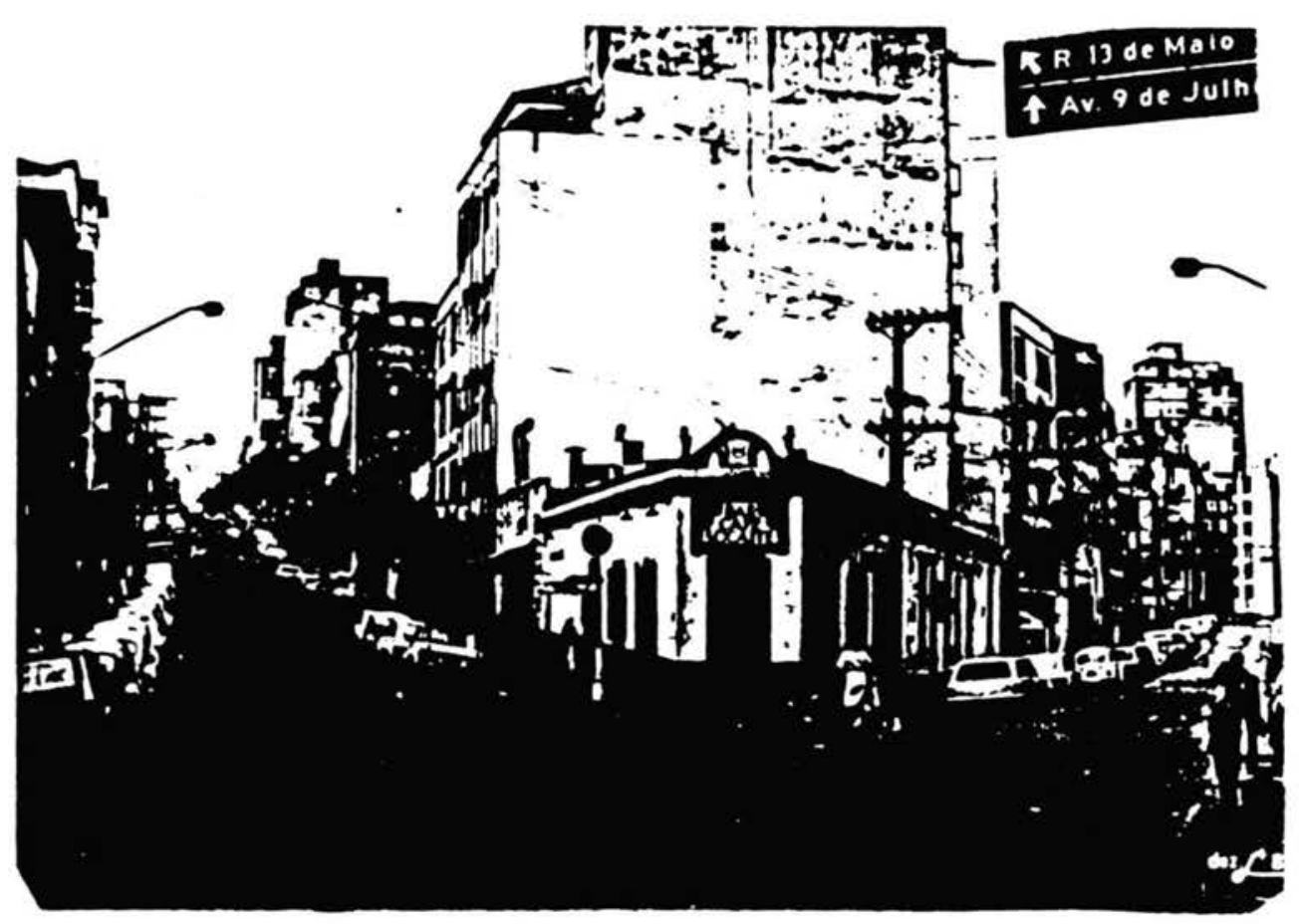

Foto 27: Rua Treze de Maio esquina com rua Santo Antonio. A casa no primeiro plano da foto, hoje ocupada por uma casa de diversão no turna, jä foi em outros tempos ocupada por um tradicional açougue do bairro. Observe-se tambēm a variação de escala arquitetō nica. (Ano: 1988) 


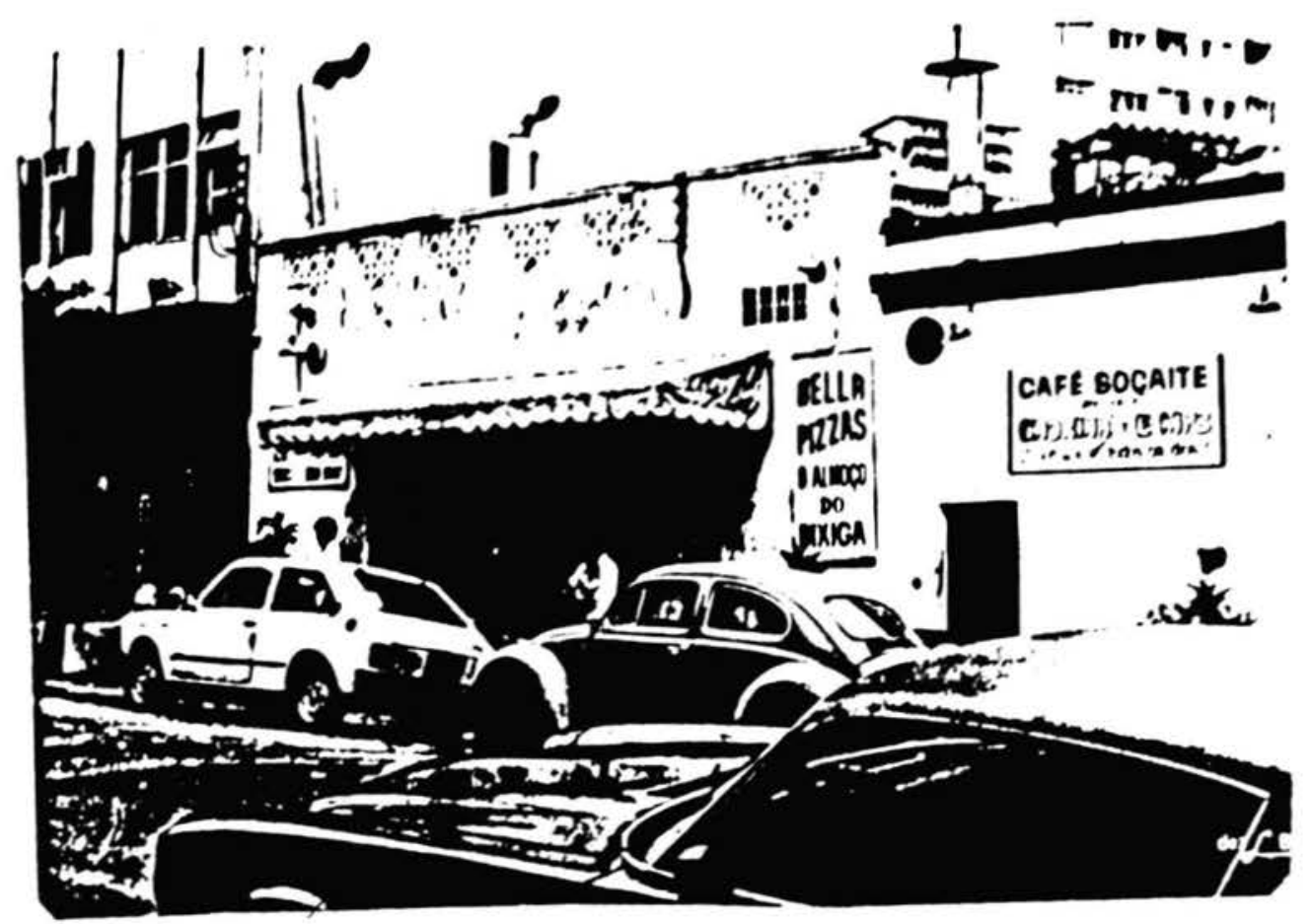

Foto 28: Casa localizada na rua Treze de Maio - nücleo de concentração das diversōes. Observe-se a "coexistência" do "antigo" e do "novo". (Ano: 1988)

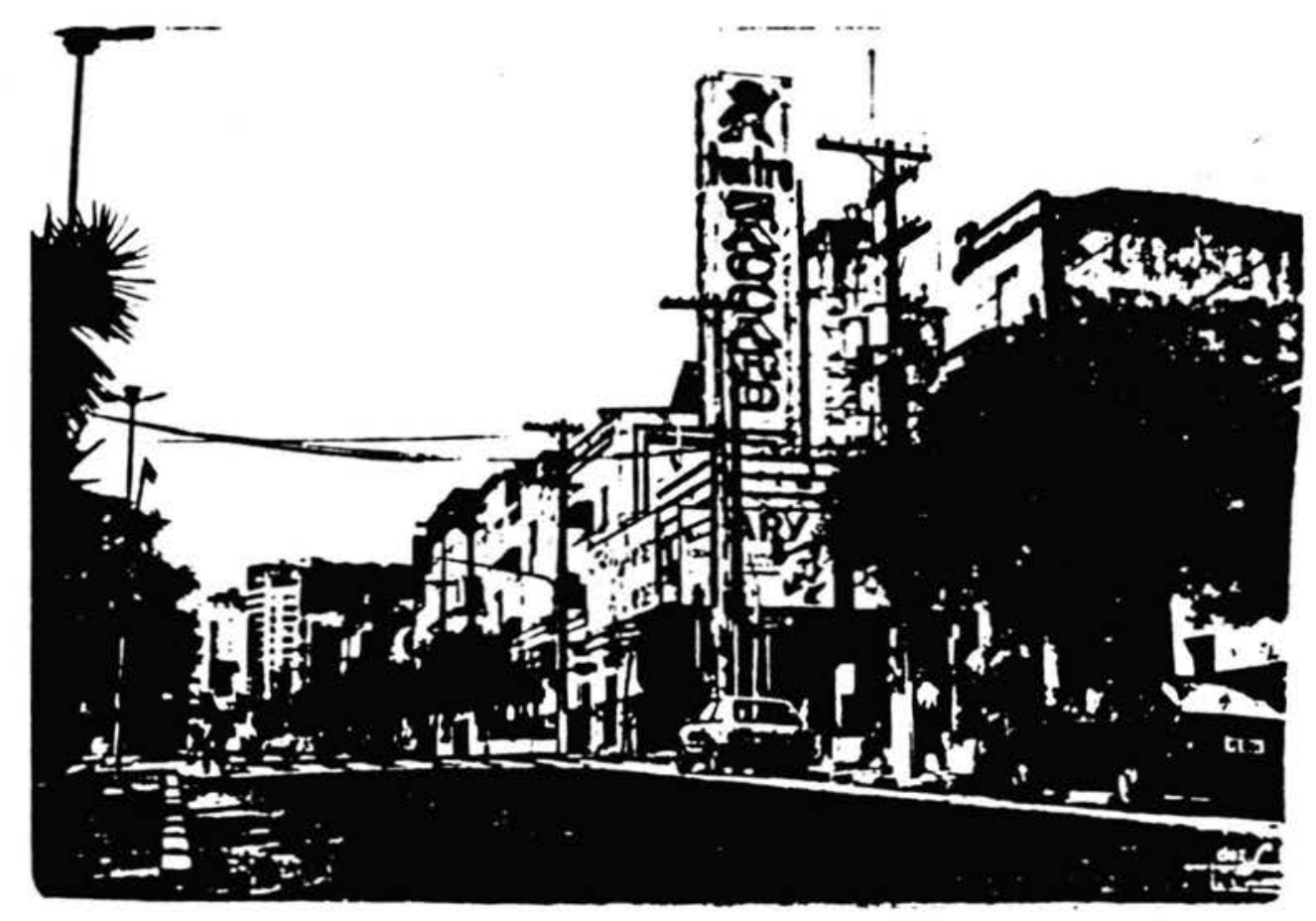

Foto 29: A "nova Rua Rui Barbosa". Nücleo de concentração de teatros, cantinas e casa de müsica e bar. (Ano: 1988) 
vidudes costavam concentradas no "velho centro": cincmas. teatros, restaurantes. Casa de chop a exemplo de algumas famosas como a Brahma e a franciscano, lugares de 'velha bocmia" paulistana ou então em casas como a Vienensc e outras casas de chá na rua Barão de Itapetininga e jmediaçōes.

Com o processo de expansāo do centro e com todas as transformaçōes ocorridas com o mesmo, estas ativi dades também foram se deslocando para outros pontos da cidade. 0 aparecimento deste nível de concentração de atividades ligadas â "indústria do lazer" no Bela Vista é uma consequência daquela tendência descentralizadora de muitas das atividades deslocadas do centro.

Hoje, novos centros estão surgindo em outros bairros a exemplo da B3. Podemos identificar aquele localizado na Henrique Schaumam e imediações de Pinheiros, com uma forte concentração de casas de diversōes noturnas, desde música e bar até casas de espetáculos, etc. Assim, tambēm, em Moema.

$$
\text { Porém, o "Novo Bexiga" ou "Bixiga", traz }
$$
consigo mais "fama e magia", podemos mesmo dizer - uma "mística". E um lugar onde o sagrado e o profano se acolhem mu tuamente. Sobre esta dimensão ideológica que envolve a pro dução do espaço podemos lembrar a seguinte colocação: "No final do século XVIII, a Terra tornou-se definitiva e exclusivamente a meta do homem, livre e totalmente voltado para a descoberta do mundo terrestre e exploração de suas riquezas, livre de símbolos, de todos os traços metafísicos. A razão substitui a fé. 0 mundo seculariza-se. No entanto, no interior deste mundo secularizado, o sagrado 


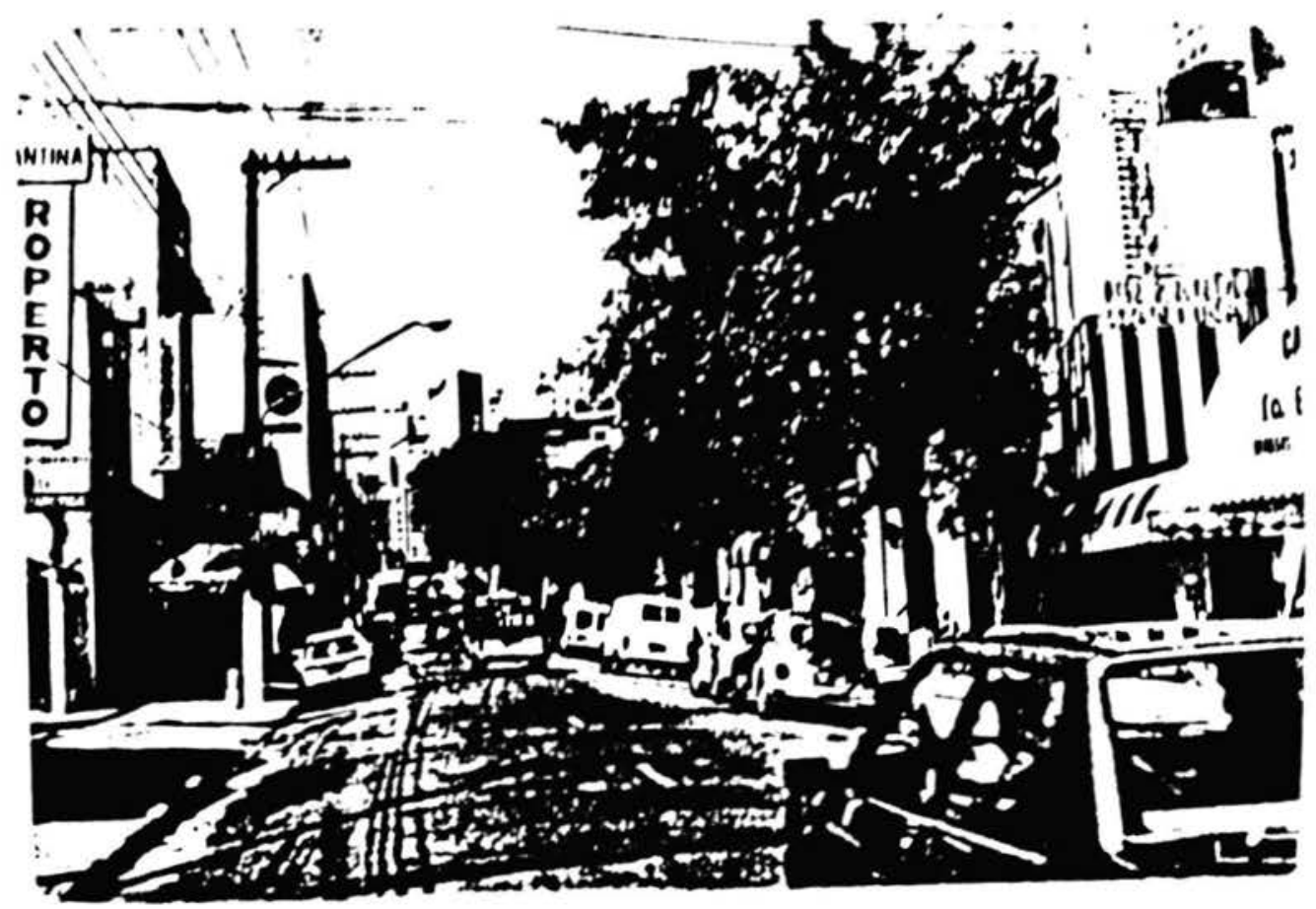

Foto 30: Rua Treze de Maio - trecho localizado entre a rua Conselheiro Carrão e rua Fortaleza. Maior nūcleo de concentração de canti nas. Area pröxima da igreja de Nossa Senhora da Achiropita. (Ano: 1988)

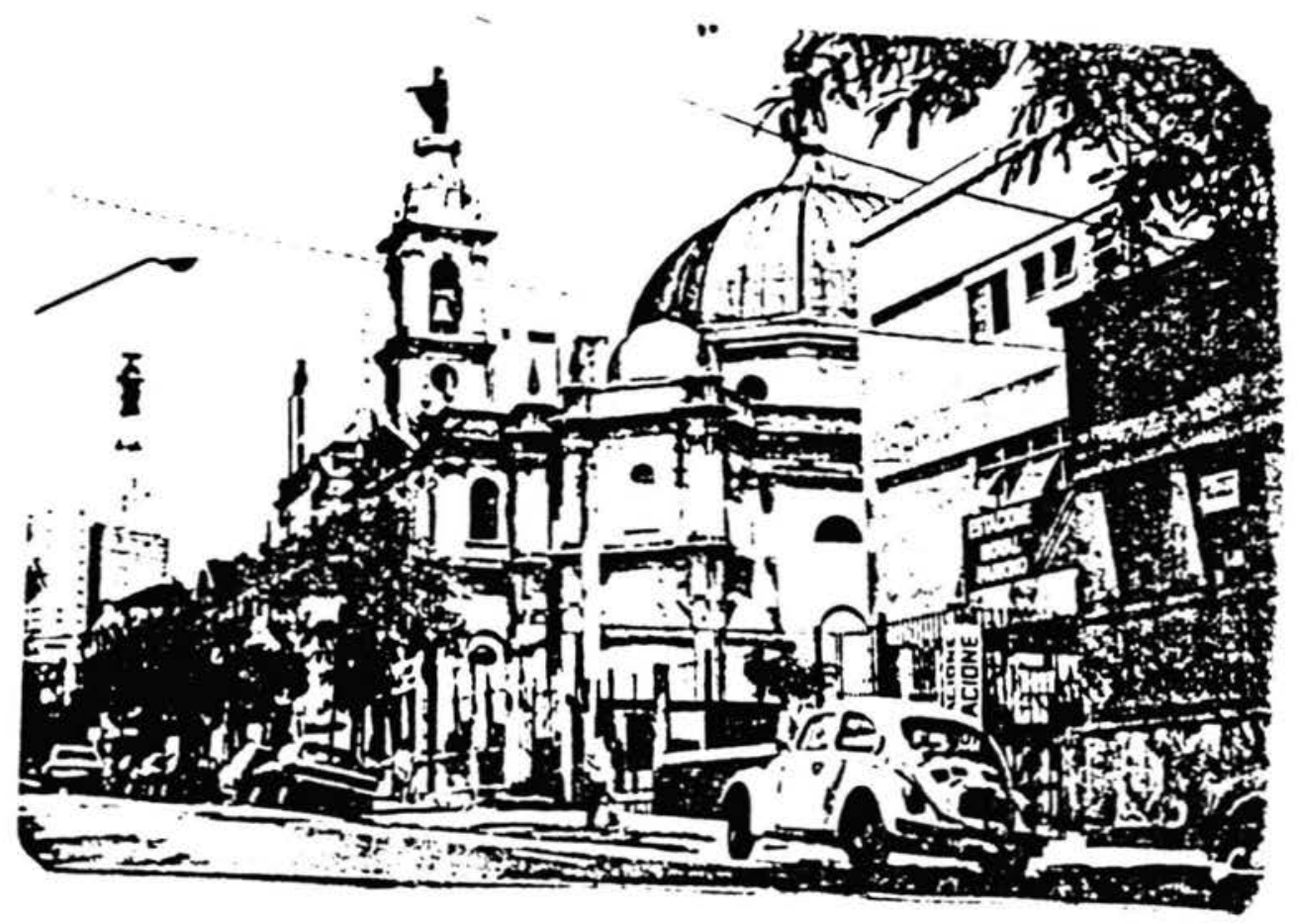

Foto 31: Igreja Nossa Senhora da Achiropita. Nesta ärea se realiza a quermesse. (Ano: 1988) 
reaparece soh outras formas, segundo o que Bettaninj denomina esfaço de representasiono (l,as:anii).

Se o século XVIJj foi para o "homem moder no" a transição da existência de um espaço "sagrado" para - "profano", para o Bexiga, foi aquele "Ano Zero"; da "sacralização pela italianitá que se viveu no passado, à profanação imposta pela "nova racionalidade" das relações capitalista que se consolidaram. Esta área do "Novo Bexiga", é onde todas aquelas representações se "misturam". Religião e "prazeres mundanos" se confundem em suas festas. Em poucos lugares o "sagrado" foi tão "profano". A "Babel" a que nos referimos anteriormente esta simbolizada neste pedaço da B3. Aqui, naqueles "sábados alucinantes", quando as ruas "fervilham" de forasteiros, aquele espaço "sagrado" das "tradicionais famílias" é roubado e "profanado". Ta vez isto explique aquele "certo encanto e magia" do lugar. Em nenhum momento isto torna-se possível de ser pensado tão intensamente como na época das festas religiosas - "a" famosa quermesse".

No mesmo momento que se vivencia no interior da área a festa religiosa, organizada pela "pequena comunidade" remanescente do tradicionalismo que mora no bair ro ou que o procura nesta época, também se vivencia nas ruas e imediações "os embalos do sábado à noite" no interior das casas de diversões noturnas.

Muitos são os que associam estas duas formas de diversões. E quando o templo da "Madonna Achiropita" é invadido pelo olhar curioso daqueles que procuram a festa como diversão. 0 que encontram são altares e santos, não mais as "velhas senhoras calabresas" vestidas de preto "re zando suas ladainhas". Para estes, festa e igreja são sim 
ples aptresados físicos naquede espaço.

Na K, vive-se de forma mais acentuado o conflito, táo apontado naqueles depoimentos: de un lado a tradição da familia e do outro as "novas diversōes". Nela permite-se a ilusão de estar se vivenciando e "curtindo"to da uma tradição "sacralizada pelo italianismo", ao mesmo tempo que se consome este espaço num ritualismo "exótico" em que se"misturam" aquelas duas formas de existência. 0 "Bixiga" transforma-se numa mercadoria "exótica", consumida, "devorada" nas cantinas e casas de diversōes, assim co mo nas quermesses, sem se perceber que se está "devorando" uma representação estimulada pela midia e pelos propagadores da "fama do bairro".

Is to nos lembra muito a citação de Marx sobre a natureza da mercadoria:

"A primeira vista, a mercadoria parece coisa trivial, imediatamente compreensível. Analisando-a, vê-se que ela é algo muito estranho, cheia de sutilezas metafísicas e ar gúcias teológicas" (Marx, p. 79).

Assim, quando se consome o "Bixiga" como produto daquela "indústria do lazer" dificilmente se perce be na mesma esta natureza. Num primeiro momento ela se apresenta como algo natural, como a realização de um ato de liberdade, como a satisfaçāo de um desejo. Porém, obser vada de forma crítica é que perceberemos toda aquela sutileza que envolve a "embalagem" deste "Tradicionalismo". Da mesma forma como se "mumificou" a B3, o "bloco histórico", pretende fazer o mesmo com o bairro na medida que generalizam pa ra todo este espaço as características da B3. Estendem, no discurso sobre a unidade politica administrativa da Bela 
Vista, uma natureza especifica daquela sub-unjade. A p.3. e "estranha" para o bajrro como um todo, cla existe para a cidade. Mesmo com a grande concentração daquelas ativida des continua sendo uma área de grande concentração da função residencial com 49,58 das ocorrências. Apesar de menor em relação à $\mathrm{B2}$, ainda é significativa a presença nela de cor tiços. Podemos dizer que a B3 é o grande símbolo dos "encontros e desencontros" entre o passado e o presente do "Bexiga".

Por ültimo, temos a Sub-unidade da Área C, núcleo de expansão não tradicional. Seus limites ficam cír cunscritos ao espigão da av. Paulista e Alto da Grota,mais precisamente, entre a rua dos Ingleses, Franceses, Ribei rão Preto, São Carlos do Pinhal, e parte da Eugênio de Lima.

Em 1930, pela Lei 3.460 foram feitas uma série de modificaçōes no traçado das ruas desta sub-unidade que envolviam o Morro dos Ingleses. Foi quando criaram a atual rua dos Franceses e dos Ingleses, dando na atual configuraçāo viāria desta parte do bairro. Quando confrontados os atuais mapas com aqueles anteriores a esta data, verificaremos que os traçados das ruas não coincidem.

Toda a transformação urbanística no traçado das quadras foi para abrigar os grandes palacetes. Compa rando-se o tamanho dos lotes desta ärea com o restante do bairro, constatamos grandes discrepancias. Na parte tradicional, como jä apoptamos, os lotes são bem menores. A ocu pação desta sub-unidade C deu-se como um prolongamento das camadas sociais que ocupavam os bairros jardins, aquela no va aristocracia paulista, pós período cafeeiro. 


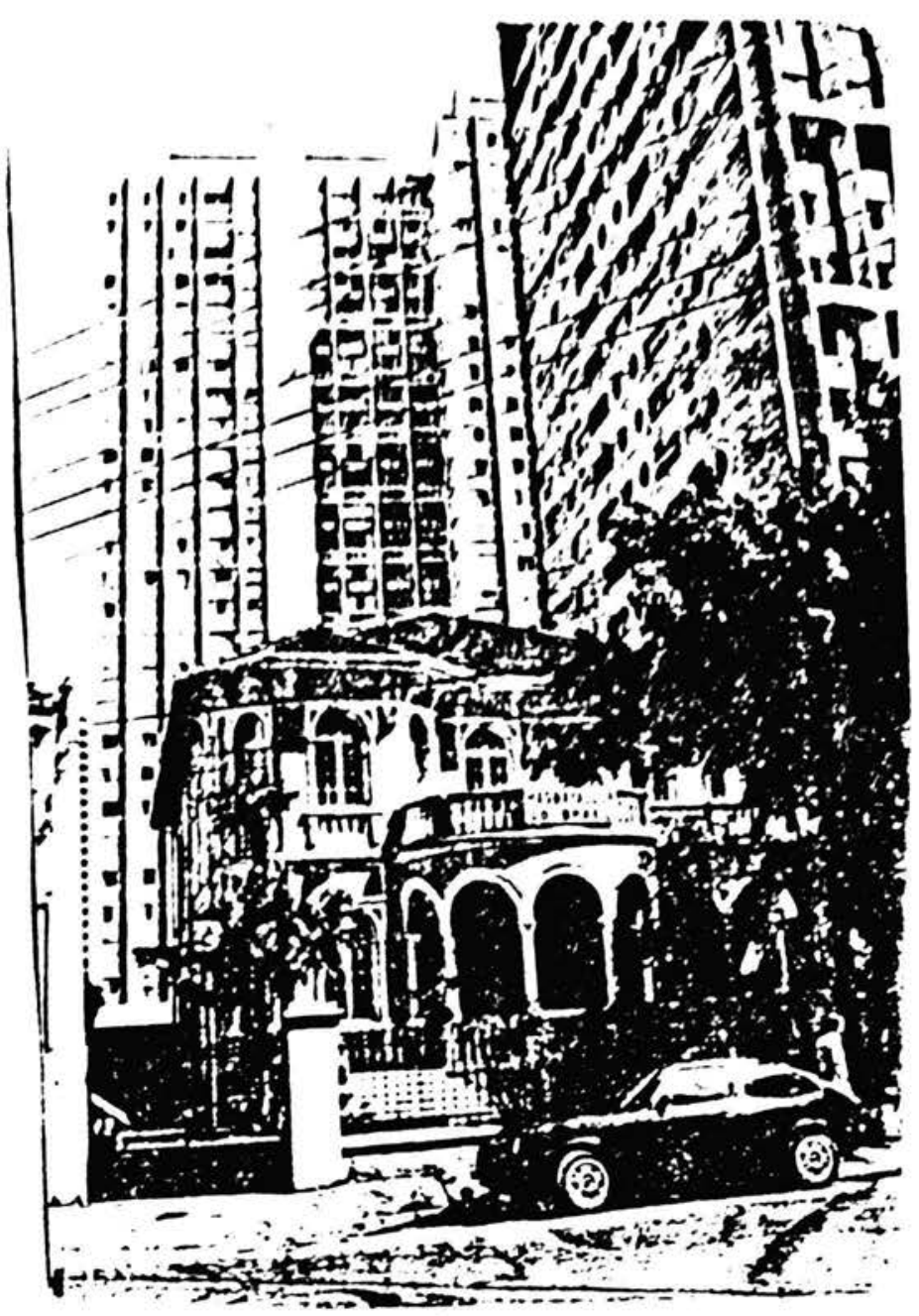

Foto 32: Rua dos france-

ses - Morro dos

Ingleses. 0 con traste entre 0

"antigo" e 0

"novo".

(Ano: 1988)

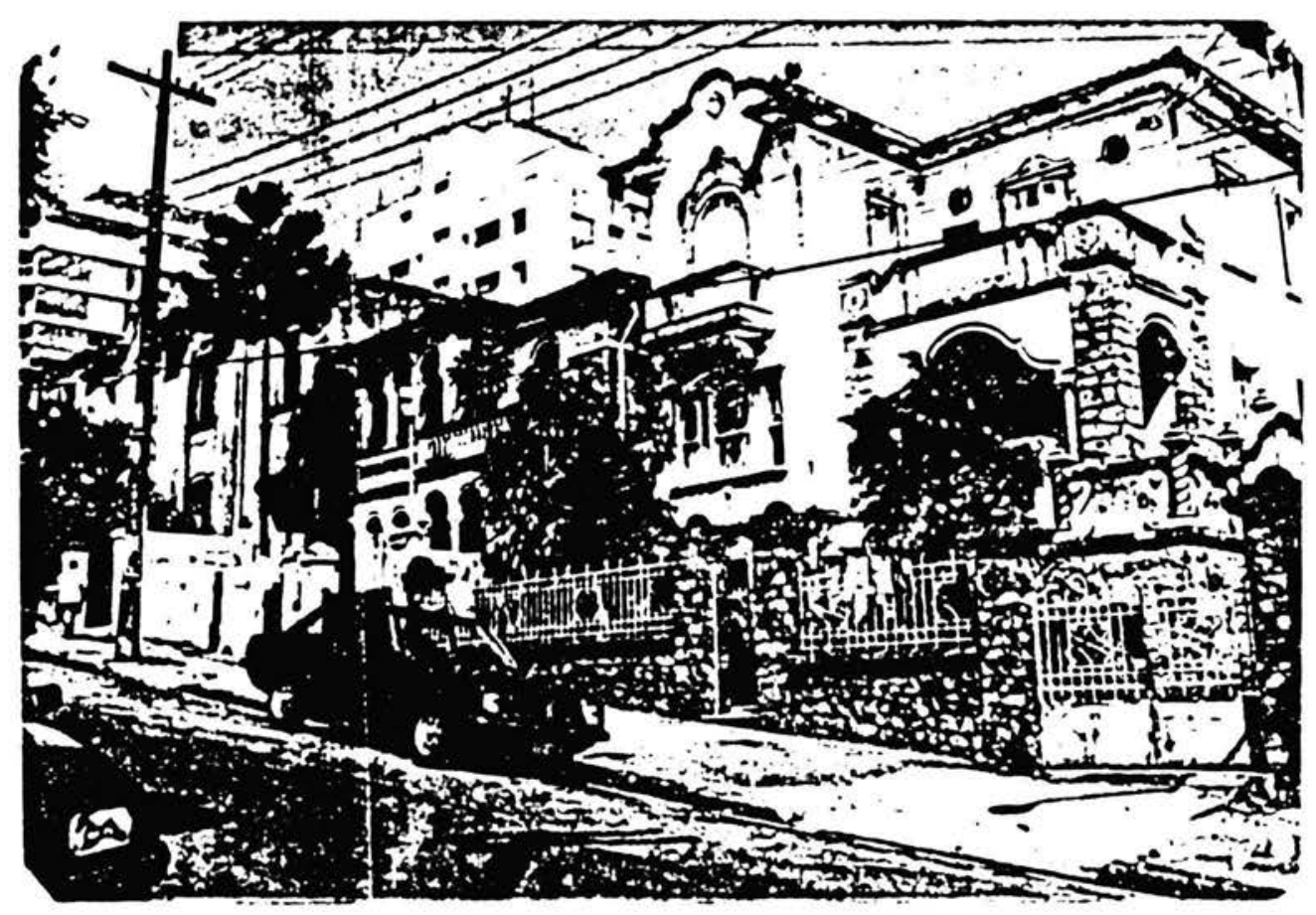

Foto 33: Casarōes localizados na rua dos Ingleses - Morro dos Ingleses. Forma de ocupação das primeiras décadas do atual século. Hoje estes casaröes estão sendo ocupados cada vez mais pelo terciärio. (Ano: 1988) 
lomo ficou colocado anterjotemente, esta phy te do hajrro, além da forma de ocupaça por uma camada social de major "poder", destaca-se também por sua topografia mais "alta", jsolando-a do conjunto da "Bcla Vista", estendida logo "ahaixo", e ligadas pelo "sobe e desce" através das escadarias da rua Fortaleza. Poucos foram aqueles ve1hos moradores que conseguiram subir para o "alto do morro", apenas alguns donos de estabelecimentos do "velho pedaço" , foram morar nos atuais prédios de apartamentos recentemente construidos nos lugares dos antigos palacetes.

Com a verticalização que atingiu a cidade de São Paulo à partir da década de cinquenta e com ela o bairro, esta sub-unidade se viu invadida por uma intensa transformação no tipo de habitaçōes. Aqueles palacetes foram sen do substituidos pelos modernos apartamentos. A reurbaniza ção que atingiu a área não significou mudanças no padrão sọ cio-econômico dos seus habitántes. Continuou sendo ocupada por uma classe social de maior renda. A função residencial continuou dominante. Do total de lotes pesquisaḑos nesta sub-unidade 71,88 destinavam-se às ocupaçōes residenciais, com 44,88 já ocupados por prédios de apartamentos de alto padrão.

0 aumento no número de prédios de apartamentos verificou-se nos últimos anos, favorecidos pelo caráter nobre que o lugar sempre desfrutou e pela natureza de seus lotes atrativos para as Companhias construtoras, semelhante ao que aconteceu com a av. Paulista. Não se verificou nesta área a presença de nenhuma indústria, raríssimas foram as vezes em que se encontrou uso misto para os lotes. Quando isto aconteceu, foi em algumas das casas geminadas que tam- 


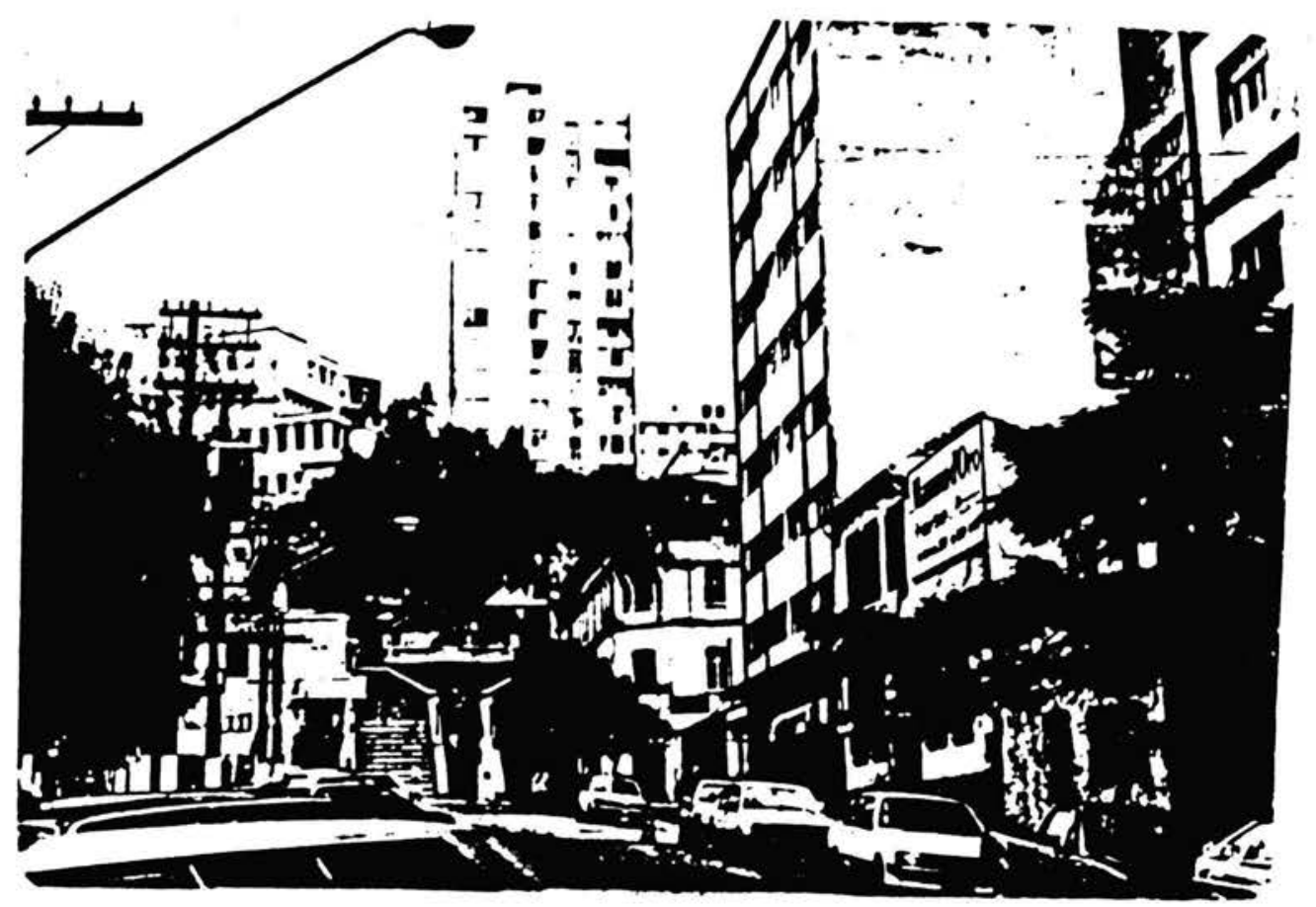

Foto 34: Escadaria da rua Fortaleza que dá acesso ao Morro dos Ingleses. Na parte inferior da foto está localizada a nova rua Rui Barbosa. Obstrução deste trecho com a outra parte da rua Fortaleza colocada alēm do "Muro de Berlim". (Ano: 1988) 
bém aj se encontram. Pequeno comércjo e pequenos serviços sũo quase inexistentes. Foj encontrado um teatro (Ruth ts cobar) c duas cantinas: a cantina do Muscu do Bixiga, na rua dos Ingleses, próxima à rua Conselheiro carrão, bem na transição com B3, assim, como outra na Al. Ribcirão Preto, também próxima do corredor da Av. Brigadeiro Luiz Antonio.

Paralelamente à entrada dos apartamentos de alto padrão, esta sub-unidade também presencia a entra da de grandes edifícios ocupados por empresas de grande porte, como a Embratel, Telesp, Petrobás, Sharp. Outras. não muito menores, ocupam os palacetes que eram da antiga aristocracia local. Esta área do bairro cada vez mais está se tornando a "porta de entrada" daquele "terciārio superior", como prolongamento das funçōes da "Nova Paulista". Este fato explica a presença de um dos hotéis "cinco estrelas" mais famosos de São Paulo - o Maksoud Plaza, onde funciona o não menos badalado "café Bela Vista". Próximo ao mesmo, foi construido um apartament-hotel, também de al to padrão.

A sub-unidade C, expressa, assim, cada vez mais o poder do grande capital dentro dos limites do bair ro. Podemos dizer que quase nada lembra a presença do antigo bairro, ou seja, o "Bixiga". E muito mais uma parte da Paulista do que do bairro no qual esta circunscrita ad ministrativamente. Em relação ao mesmo parece-nos mais um "ponto de observação" que do 'alto do morro' olha para aque le "mundo em transe", o Bela Vista que se descortina deste mirante, que um dia vislumbrou aquelas suaves colinas que se estendiam em direçāo ao Ribeirão Bexiga e Vale do A- 
nhangabaú, ou então ao fundo da grota (1ig. 11).

Parece-nos, portanto, que qualquer generalj zação que se faça entre aqueles três termos - Bela Vista. Bexiga " "Bixiga", tanto sobre sua evoluçāo histórica quan to suas caracteristicas de estrutura morfologia urbana, redundarà em perda de transparência do que seja realmente esta "unidade" do espaço paulistano.

Somente através desta abordagem histoórica do espaço, procurando não somente na instância infraestrutural mas tambēm nas ideologias produzidas, poderemos encontrar a transparência daquela "tridimensionalidade" espaço-temporal, que para nós são instâncias de um processo que se "totaliza" e que para outros é um todo indiferencią vel. 
ASPECTOS FISIOGRÁFICOS DO BAIRRO DO BEXIGA

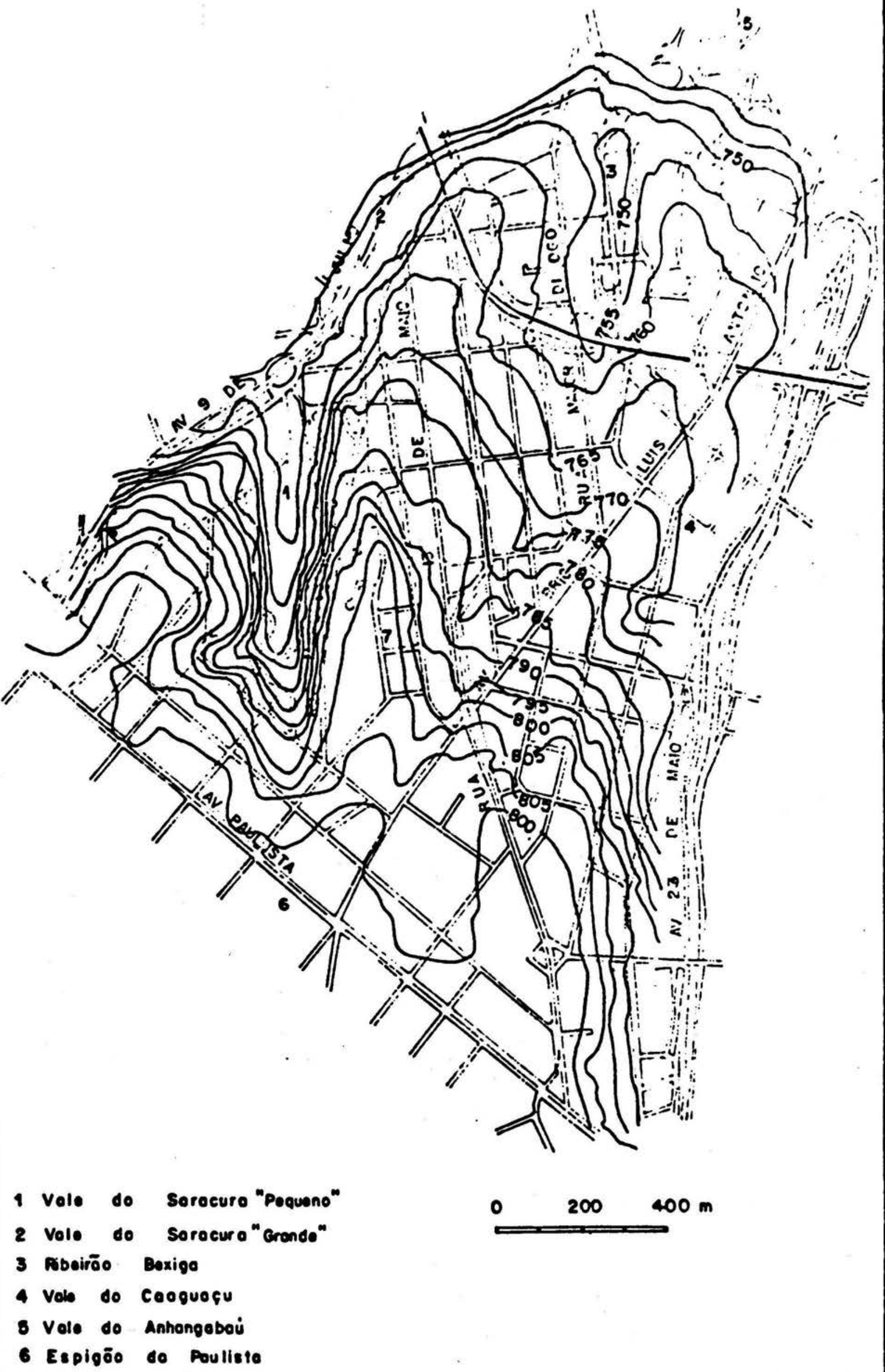

7 Morro dos Ingleses

Fonto: Corto- Cera Cosor - EMPLASA-1981. Des. :Orito. 
5. AS PROHOSIAS III. KLNOVACXO IIRBANA PARA O BIIA VISTA BLXJGA

"Rio (Sucursa1) Vegctação abun dante, ruas e praças arborizadas e ampliação de atividades recreativas e culturais serão algumas das novas característi cas do bairro do Bexiga a serem realizadas pelo Projeto Grota que desde ontem entrou em exposição num estande da Prefeitura de São Paulo no II Encontro Nacional da Constru ção que se realiza no Hotel $\mathrm{Na}$ cional do Rio.

O Projeto já em poder da Empre sa Municipal de Urbanização foi apresentado ao prefeito $\mathrm{Mi}$ guel Colasuono na semana passa da está sendo mostrado no Rio como exemplo da interven ção do poder püblico no proces so de reurbanização da cidade. A execução do projeto denomina do Parque da Grota seguirā o processo de intervenção Geral do Plano Diretor da Bela Vista ... 0 projeto estabelece que se mantenha junto ao centro da 


\begin{abstract}
cjoade uma area habitacjonas que tefroduza uma forma entj quecedorá de convivio e de tra balho. Esta determinação inclui incentivo e ampliação de atividades de recreaçāo e culturais destinadas a toda a cidade e também ao turismo". (Fo Tha de São Paulo, 10/12/74)
\end{abstract}

Quando analisado o conjunto dos bairros de São Paulo quanto à sua identificação o da Bela Vista apresenta-se como um de grande destaque, "novamente" chamado àe Bexiga ou "Bixiga". E, também, um daqueles que mais vem recebendo atenção dos poderes públicos quanto às propostas de renovação; ao mesmo tempo vem permitindo o levantamento de sérias polêmicas sobre a natureza destas propostas. Entendendo-se como proposta de renovação toda a estratégia que envolve o planejamento urbano enquanto "uma politica para o espaço urbano" que se desdobra em: política de preservação, ordenação e reurbanização.

Teremos oportunidade de encarar a nossa crí tica sobre o que foi proposto como renovaçāo urbana para o bairro e compreender a polêmica criada sobre o mesmo. Obviamente que não poderemos tratar isoladamente cada uma da quelas instâncias, do que seja a proposta de renovaçāo. Pro curaremos abordá-la globalmente. Como aquele artigo de um importante jornal de São Paulo apontado na introdução deste capítulo nos diz: a renovação do bairro apresenta-se re vestida da envergadura de um "verdadeiro" Plano Diretor,co locando o Bela Vista de forma destacada no conjunto das 
preocupasiós do poder públjco sobre o processo de renovaSão urhana de São paulo.

Para melhor comprecndermos a polêmica criada sobre o bairro, contemplado em 1974 com o projeto da Grota, devemos explicar o processo que envolve atualmente os debates no interior da Câmara Municipal de São Paulo so bre o destino do atual Plano Diretor da Cidade.

O PDDI - Plano Diretor de Desenvolvimento Integrado, criado pela Lei 7.688 de $30 / 12 / 71$ como um dos objetivos básicos para agir como instrumento de interven ção no processo de renovação urbana de SãoPaulo, esteve sendo aplicado sem grandes alteraçōes no seu conjunto de leis e procedimentos de funcionamento, até que em 1985, pe la Lei $n^{\bullet} 9841$ de $4 / 1 / 85$, criou-se a Lei de Comissão de zo neamento que alterava a composição e competência da comissão de Zoneamento da Secretaria Municipal de Planejamento. A Lei Géral de Zoneamento foi criada logo após a criação do PDDI em 1/11/72. Assim, a criação da Lei 9.841 acirrou, os ânimos dos parlamentares e interessados em preservar a referida lei dentro do espírito de sua criação.

0 argumento e justificativa para àquela alteração, feita pela atual gestão do poder püblico munici pal, era de "tornä-la mais representativa dos interesses gerais da sociedade paulistana". Para tanto foram incluí dos no interior da mesma, representantes de vários setores da sociedade. Segundo os críticos que se posicionaram contra as referidas alteraçōes, estas vieram esvaziar o poder Legislativo no interior das decisōes da antiga comissão.

Dentro deste mesmo espirito crítico, alegavam que a inclusāo de outros membros da sociedade civil pọ 
deria abrir espaço para manobras que contrariassem os inte resses públicos: para tanto, defendem a preservação do poder Legislativo no interior desta comissão.

Em março de 1988 e prefeito de São Paulo en viou à Câmara Municipal de São Paulo outra proposta de alteração da composição da comissão, onde se excluiam os vereadores e aumentava a participação de entidades, acrescen tando à comissão a FIESP - Federaçāo das Indústrias do Estado de São Paulo, a CUT - Central Onica dos Trabalhadores, - SINDUSCON - SP - Sindicato da Indústria da Construção, o SECOVI - Sindicato das Empresas de Compra e Venda, Locação e Administração de Imóveis de S. Paulo e a Federação do Co mércio do Estado de São Paulo, além do Conselho Coordena dor das Associaçōes de Moradores, considerados mais representativos da sociedade. 0 referido projeto de alteração foi aprovado em abril de 1988 por decurso de prazo. Foi aumentado também o número de representantes do poder execu tivo do município na comissão.

Para o vereador Arnaldo Madeira, a grande questāo é tornar esta comissão efetivamente representativa da cidade como um todo e não transformar a Comissão de Zoneamento em uma comissão da cidade e não apenas da Sempla" (Shopping News $13 / 3 / 88$ ). Assim, parece-nos que a questão sobre as alterações na comissão estã sendo mais sobre a efetivaçāo da "legitimidade" de seu funcionamento do que simplesmente pela ampliação da sua esfera de poder. Seus críticos temem que os grupos que formam a mesma, através de aconchavos, coloquem em risco os interesses da sociedade como um todo.

Paralelamente a estas alteraçōes, o poder 
cxccutivo cncaminhou à Câmara do Municipio de São laujo um novo projeto de Pbll, que está sendo alvo de muitas críticas, tanto pela sociedade civil, como pela "classc politica" do município. o referido projeto, até o momento da rea lização do presente trabalho, ainda não havia sido votado, mas, ao que tudo indica, deverá ser aprovado por decurso de prazo.

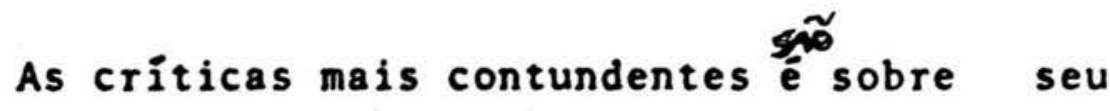
caráter "vago", principalmente pelo fato de "estimular" a especulação imobiliāria. Assim foi colocada a questão por um órgāo de imprensa que de há muito vem acompanhando de perto a polêmica sobre as questōes das transformaçōes urba nas de São Paulo: "O projeto do Novo Plano Diretor da cida de ainda nem foi enviado para a Câmara Municipal, mas já conta com adversários dispostos a lutar para que ele não seja aprovado. 0 movimento "Defenda São Paulo" - que con grega 50 sociedades Amigos de Bairros da capital - é um deles. Os coordenadores do movimento reuniram-se na ültima quarta feira para decidir como encaminhar a luta contra o Plano Diretor cuja proposta de adensamento urbano, seu carro chefe, é por eles considerada um convite à especulação imobiliāria... resume o arquiteto Roberto Saruê, diretor da sociedade dos amigos dos Jardins Europa e Paulistano: "O Plano praticamente entrega a gestão da cidade à indústria imobiliāria... De qualquer forma, o movimento continuarā a efetuar gestōes junto aos bancos internacionais, para que eles não liberem empréstimos para a Prefeitura to car as obras. Segundo a coordenação do "Defenda São Paulo", - Banco Mundial jā teria sustado os seus" (Shopping News, 19/6/88). As pressões sỏbre os empréstimos estão relacione 
das a obras que consideram questionáveis no interior da reurbanização de São Paulo, entre elas, as do túncl e da avénida que vaj passar sob o rio Pinheiros.

Criada a polêmica sobre o "novo" PDDI e o destino da lei de Zoneamento, a questão do Bela Vista veio à tona. Assim, como os demais bairros, o processo de crescimento espacial do bairro esteve sob o controle da refer $\underline{i}$ da Lei de Zoneamento, que, a "trancos e barrancos", veio de uma certa forma "controlando" aquele adensamento, o que não significou, como já tivemos oportunidade de demonstrar que o mesmo não tivesse ocorrido. A verticalização, lenta e gradual vem ocorrendo até os dias de hoje. 0 que os críticos da mudança querem é evitar que a coisa descambe defí nitivamente. Ainda o bairro está enquadrado pela léi das "zonas de uso especiais" a $\underline{28}$.

Pela Lei 8.328 de $2 / 12 / 75$ que controla estas zonas, assim, fica definido o espirito da mesma: "Es tas unidades territoriais relacionadas caracterizam-se, de um modo geral, por abrigarem usos institucionais especiais (por ex. aeroportos) ou por se encontrarem total ou parcialmente ocupada ou, ainda, por estarem submetidas a intenso processo de transformação, sob impacto de vultuosos investimentos públicos e da dinâmica da estruturação urbana. Constituem, portanto, um "estoque" de āreas do município a merecer um tratamento especial, sob uma visão de conjunto do processo de desenvolvimento urbano, que estima-se a ordenar e controlar" (Coletânea das Leis e Decretos de Parla mento, uso e ocupação do solo-PMSP, p. 247).

Pelas suas características, o Bela Vista foi contemplado juntamente con o bairro da Luz com um capí 
tulo especifico no interior daquela lej, assim expresso:

"Capitulo VJ - Das disposiçōes kspeciais.lis tes dois bairros foram considerados pelas suas caracteristicas, como relevantes no processo de renovação urbana que se pretendia para São Paulo, destacando-se, assim . no conjunto das áreas especiais - "Com a presente propositura, altera-se fundamental mente o papel das zonas especiais 28 . De áreas consideradas "indefinidas" ou "congeladas", passam a ser zonas estudadas de modo muito mais profundo e minucioso, sendo objeto de um zoneamento baseado em microäreas" (Coletâneas das Leis e Decretos de Parcelamento, Uso e Ocupaçāo do Solo, PMSP. p. 241).

Desta forma, a Lei 8.328 veio precisar obje tivos mais "bem definidos" sobre a situação das "zonas de uso especiais", em relaçāo à Lei Geral do Zoneamento de 1972. E importante lembrar, também, que aquela lei que diz ter vindo "descongelar" e "definir" os usos especiais para. - Bela Vista, foi elaborada logo após as grandes obras de reurbanização sofridas pelo bairro, e que muitas obras de verticalização ocorreram após aquele período.

Desta forma, hoje, após todos estes anos, quando veio à tona a polêmica sobre o destino da cidade,de vemos retomar aqueles projetos que haviam sido feitos para o bairro, que, questionāveis ou não, davam "certas dire trizes" para seu crescimento. As ameaças trazidas com a proposta do "Novo PDDI" e as investidas feitas paulatina mente no interior do bairro pela indústria da construçāo civil leva-nos a questionar neste momento todos aqueles "Planos Diretores", contidos no interior dos Estudos Básicos, PR-016, Bela Vista-28-010 feitos pela COGEP-PMSP em 
1974, dos quais resujtou o projeto da Cirota coutros majs

- Projeto 13 de Majo, além daquele sobre a Vila jororó, por muitos considerudu como "prolongamento" do "Velho kex ga" (porém, fora dos nossos estudos).

Estes Planos Diretores foram realizados num momento em que o Bexiga vivia aquele "Ano Zero". Foi naque le contexto histórico que se elaborou o Projeto PR-073, Projeto Grota e o Dossie 038, Projeto 13 de Maio em 1975. Estes dois projetos, principalmente o da Grota, passaram a simbolizar para o processo de renovação urbana dos bairros de São Paulo, algo de inovador. $\AA$ partir de então, o nome do bairro passou a ser ventilado periodicamente nos jornais da cidade e, como vimos, fora da cidade de São Paulo. Assim se expressou um jornal de São Paulo na época: "Enquanto o velho Bexiga lamenta, começa a surgir a nova Bela Vista" (Folha de Sāo Paulo, 15/4/74).

Este clima de conflitos, sugerido no período já guardava em $s i$ todas as contradiçōes contidas entre as formas de intervenção do poder püblico através daqueles Planos Diretores as propostas de renovação urbana para - bairro, com os interesses daqueles que anteriormente cha mamos de componentes do "bloco histórico". As contradiçōes foram se revelando à medida que as propostas de renovação foram se tornando inviáveis, tanto em relação aos seus objetivos como em relaçāo às "brechas" que estes Plano Dire tores criaram para a "invasāo incontrolada da vertical $\underline{i}$ 2 açāo.

A medida que os projetos foram feitos a que - bairro foi colocado sob a "guarda" da Lei de Uso Especial, os posicionamentos da população representativa do 
tradicionalismo - o "bloco histórico", foram revelundo os conflitos c contradições existentes no seu interior. Alguns viam no projeto uma ameaça às tradiçóes enquanto outros viam com esperança a regeneração" do baírro. Como veremos mais adiante, projetos jả nasceram comprometidos com os interesses das companhias construtoras privadas. Isto explica em grande parte a frustração na concretizaçāo dos mesmos. A elaboração destes projetos criou diferentes expectativas e comportamentos junto à "comunidade" do bairro. Em parte, pela natureza dos mesmos, mas também pela expectativa criada e concretizada que aos poucos foi dando lugar às duvidas e incertezas com todas aquelas mudanças nas Leis de Zoneamento e propostas de novos planos diretores.

No interior da "comunidade" alguns os encararam com certo pessimismo devido à imagem da "mutilação" deixą das por aqueles projetos viårios de reurbanização; as desapropria çōes que, além de expulsarem os antigos moradores, não foram pagas à contento dos mesmos. Outros proprietários desde a criação da Lei Geral de Zoneamento e no seu desdobramento com a Lei $9.725 / 84$ a 28-200, acharam que estas leis acabaram criando alguns obstáculos para que as negociaçōes com as grandes construtoras no mercado imobiliário se realizassem "livremente". Outros ficaram entre a perspectiva da "regeneração", a contenção do processo de "deterioração" e a ativação das atividades turísticas no bairro pela expansão das cantinas e diversōes, ligadas as tradiçōes do bairro.

Na época da divulgaçāo e elaboração dos projetos, colocou-se enfaticamente, que um dos objetivos dos mesmos era "recuperar as tradiçōes do bairro". 0 que 
não perceberam, foram as "sutilezas" dos mesmos. Quandó o Plano Direzor felto para o bairro em 1974 para implantaçà̃o do projeto da Grota se reféria à politica de preservacão vinha acompanhado da seguinte frase - "sempre que possivel". Os interesses demonstrados pelas companhias construtoras revelaram ser impossivel conciliar os dois objet vos do Projeto: preservar e reurbanizar. A própria Lei 28-200 apresenta-se pouco fortalecida no conjunto das estruturas jurídicas para que possa dar sustenção à sua aplí cação. Segundo o texto da mesma: "Qualquer intervenção nes tes imóveis preservados depende de um parecer da Secreta ria Municipal de Planejamento", e parece que, em relação aos interesses do bairro, os pareceres foram desfavoráveis ou então revelaram a ineficácia da Lei. Lembremos a demolí ção da Vila São José. Esta Vila, não chegou a ser colocada sob a proteçāo da referida lei. Morosidade ou negligência na aplicação da:mesma? A verticalização indiscriminada que vem assaltando o bairro parece-nos a evidência maior da sua fragilidade.

Um dos grandes desafios para a $28-200$,e que representa no momento a grande ameaça para o bairro e os interesses daquelas lideranças frente às novas propostas de reformas na lei de zoneamento, é a rua 13 de Maio, colo cada sob a proteção da referida lei. Este fato explica, ainda, a presença de uma grande concentração de residências baixas ao longo desta rua e suas imediaçōes. E bom lembrar que a aplicação da lei estende-se a um raio determina do ao redor do imóvel colocado sob suaproteçāo, conforme podemos comprovar no conjunto de bens protegidos pela mesma: "Em seguida outras leis acrescentaram novos exemplares 


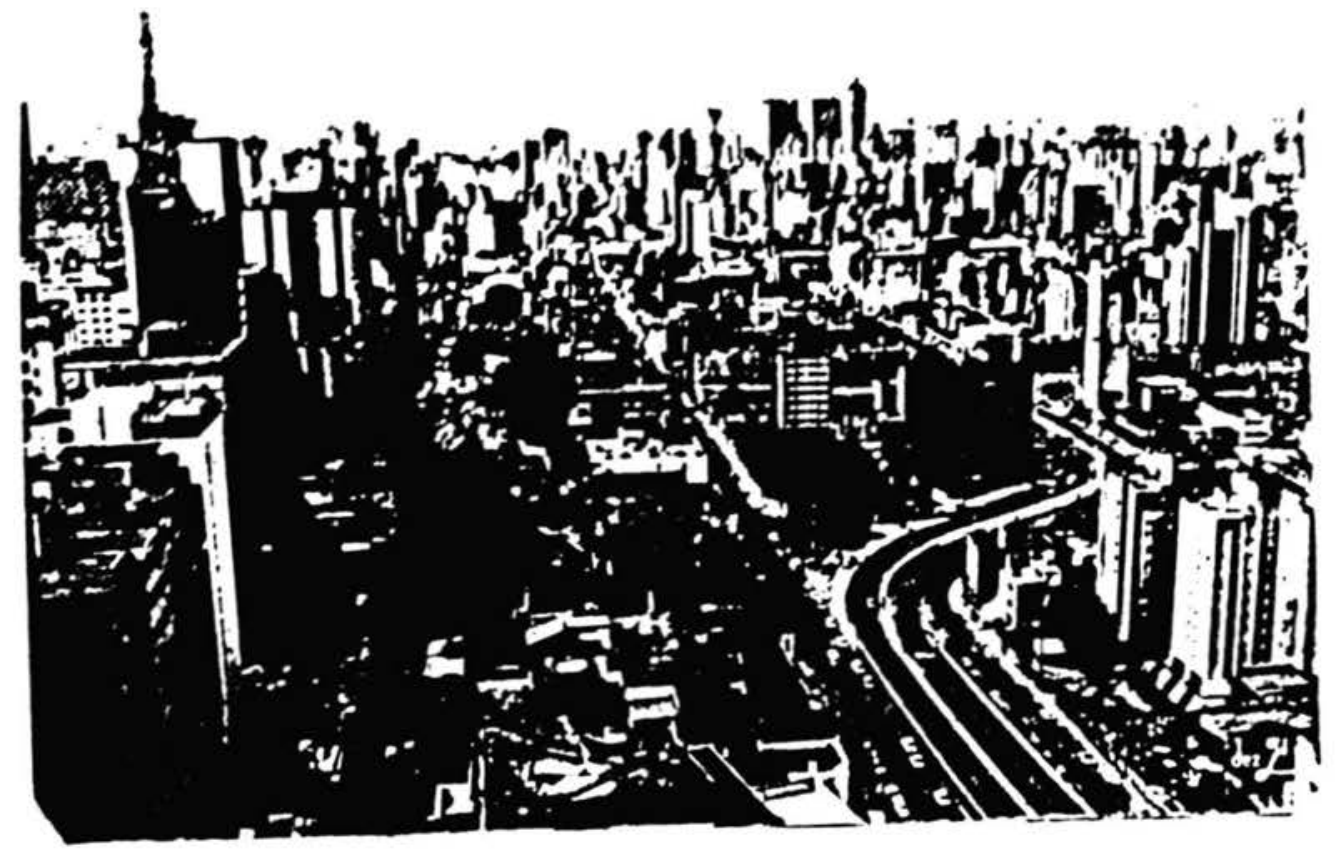

Foto 35: Visão panorâmica do Bexiga tirada do Morro dos Ingleses. No prí meiro plano da foto o eixo da rua Treze de Maio e nova rua Rui Barbosa. Observar a grande concentração do casario. E uma das äreas onde a concentraçāo das casas de diversōes e cantinas se apresenta mais concentrada. Nücleo da $B 3$ que melhor representa a "revitalização" do bairro. No plano de fundo o "velho centro"r de São Paulo. (Ano: 1988) 
significativos à listagem dos bens preservados, tais como ... a Vila jzorotó c os imóveis da rua 13 de Maio, impor. tantes marcos arquitetónicos do bairro da Bela Vista, antí go "Bexiga" (Bens Culturais ARquitetónicos no Município e na Região Metropolitana de São Paulo - Sempla - Emplasa SP, p. 12). Ao mesmo tempo que a lei favoreceu a manuten ção dos casarios, favoreceu também, a consolidação daque las atividades caracterizadoras do bairro.

Na medida em que aqueles projetos foram de grande importância para a história do bairro, mais pelo pa pel de destaque que permitiu a este, do que pela sua efeti va concretização, os mesmos merecem um estudo mais detalha do aqui.

A elaboração dos projetos foi acompanhado de um conjunto de Estudos Básicos, denominados por PR-016, Bela Vista, 28-010, formado ao todo por sete volumes. Nestes estudos a COGEP-PMSP define o que seja um programa de renovação urbana: "Constitui um processo de intervenção que integra a ação do poder público e a iniciativa privada em operações combinadas de preservação, ordenação e reurba nização visando incrementar a qualidade de vida urbana... Reurbanização - medidas de redefinição de funções, renovação de edifícios existentes por deterioração grave, estabe lecimento de novo traçado para a área, com destruição de āreas e edifícios para novo uso" (PR-016, p. 1-2).

0 conceito de renovação, passa, assim, a ser mais abrangente do que o de reurbanização. Inclui no seu interior a política de ordenação, ou seja a estratégia de crescimento do espaço urbano e a política de preserva ção - definição do que deve ou nāo ser definido como "im- 
portante para a memória da cidade". Aquejes Estudos bási. cos não se limitaram somente a fazer o levantamento das ca racteristicas e tendencias sócio-cconômicas para o bairro, entre o período de 1973 e 1974, mas também fizeram um exaustivo estudo sob a expectativa das companhias ligadas à indústria da construção civil que, como vimos, foram chama das para o interior dos objetivos dos projetos. Através dos confrontos destes objetivos com as expectativas daquelas empresas, percebemos várias contradiçōes que envolvem estas duas esferas de interesses - a do setor público e a do privado. Observando mais de perto os preâmbulos dos pro jetos, Grota e 13 de Maio, poderemos identificar melhor es tas contradiçōes. Vejamos como ficaram definidos os objetí vos gerais do Plano Diretor da 28-010 - Bela Vista:

"I - Promover melhoramentos urbanos dentro de uma operação combinada de renovação urba na e integraçāo social.

II - Contribuir para incrementar a qualidade da vida urbana

- preservando áreas que denotem a evolução histórica da cidade e valorizando a pai sagem urbana;

- preservando sua personalidade sóciocultural;

- atraindo atividades altamente especializadas atendendo às exigências do centro principal do qual faz parte:

- provendo equipametnos não só de nível local mas também de nível compatível à função do centro principal;

- provendo facilidades de circulação;

- provendo novas unidades habitacionais;

- minimizando a relocação de moradores e de atividades econômicas" (PR-016. p. 1-2). 
Im outro preâmbulo sobre a definição dos ob letivos gerais, o plano assim se refere:

"Nesses antecedentes talvez a vocação da área:

a) ver sua antiga paisagem reconstituida na medida do possivel

b) voltar a ser local de uso público, sem

as limitaçōes dos mini-loteamentos:

c) receber moradias de caráter popular;

d) acolher restaurantes típicos da região

e) abrigar centros de música popular

f) restabelecer a vida comunitária que come ça nos lugares de recreaçāo" (PR-073 - Grotá da Bela Vista, p. 7).

Para a concretização do Projeto da Grota (Fig. 12), elaborado segundo aqueles objetivos gerais, ficaram estabelecidas no projeto as seguintes realizaçōes a serem implantadas:

1. Habitação - construção de 984 unidades para cinco moradores em média, distribuidas em apartamentos de 2 ou três dormitórios e áreas de 50 a setenta metros quadrados;

2. Educação - construção de 1 escola de $1^{\circ}$ e $2^{\circ}$ grau e um centro infantil integrado que deverá ser construído junto às habitaçōes com capacidade para 1.600 alunos, incluindo uma creche, um parque infantil e um posto de saúde;

3. Saúde - a proximidade com áreas bem providas dispensou a necessidade destas implantações, o posto de saúde integrado ao centro infantil resolvia o problema;

4. Hotel - pela pesquisa junto à classe empresarial, havia se confirmado a construção de um hotel com 300 leitos;

5. Espetáculos e Diversōes - espaços para a evoluçāo da es cola de samba, escola de aprendizagem musical e aproveitamento da paisagem para apresentaçōes musicais em geral. A 
PROJETO BROTA PR- C.73

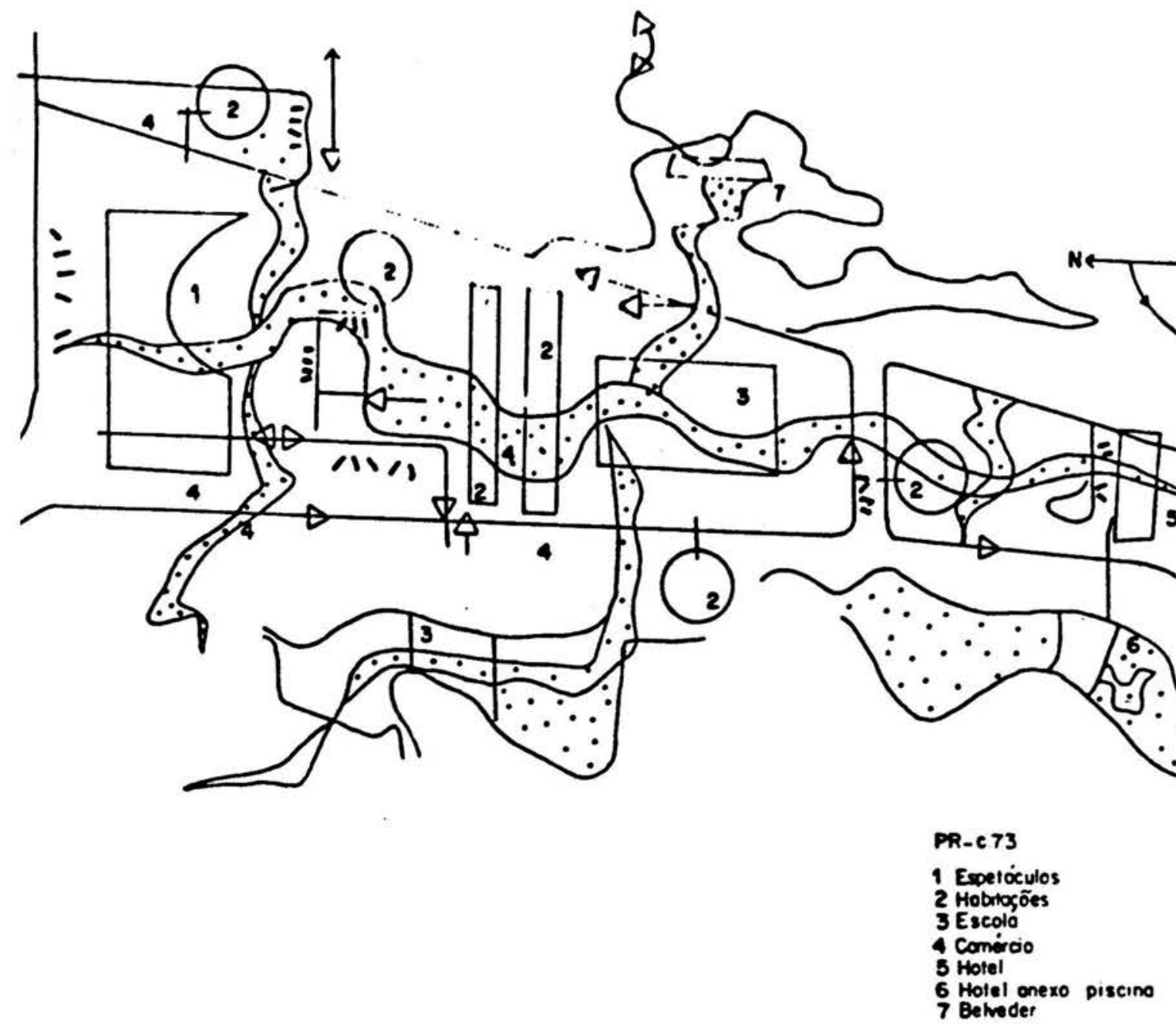


escola de música deveria atender à comunjdade com cursos $1 \underline{\text { i }}$ vres. No mesmo parque, junto ao conjunto da escola de samba e scu espaço de evolução, a criação de um outro conjunto:c nema, teatro e casa de baile. Os restaurantes ficariam para a iniciatíva prívada nos espaços destínados ao comércio.

6. Sistema Viário - construção de garagens, cobertas, de propriedade da municipalidade em dois niveis, com capacidade para 1.500 veículo.

7. Zoneamento e Paisagismo - os edifícios deveriam ser cons truidos sobre pilotis, evitando assim as ruas com "paredes" ao mesmo tempo que deveriam ser construidos no conjunto,"be los jardins" com densa vegetação (idem, p. 7-20).

Quanto ao Projeto 13 de Maio, o mesmo estabe lecia as seguintes obras de reurbanização: - Transformação do trecho entre a av. Brigadeiro Luiz Antonio e a rua Manuel Dutra em área de "calçadōes", onde, juntamente com as ruas transversais seriam construidas pequenas praças inte riores - criação de uma praça para o teatro, teatro ao ar livre. Uma grande praça para um cinema ao ar livre, sob. a qual se construiria um grande estacionamento, isto na rua Manuel Dutra, entre a rua 13 de Maio e rua Rui Barbosa. Todas estas atividades do Projeto 13 de Maio estavam ligados ao processo de "revitalização" pela qual passava esta subunidade $\underline{B 3}$.

Fazendo-se um balanço de tudo que foi proposto nos referidos projetos com aquilo que efetivamente foi feito e comprovado pela atual pesquisa, chegamos à conclusāo que quase nada foi feito. 0 pouco que foi realizado, o foi de modo muito precário. Para o Projeto Grota, a única coisa constatada foi um "palanque improvisado" bem na entrada da 


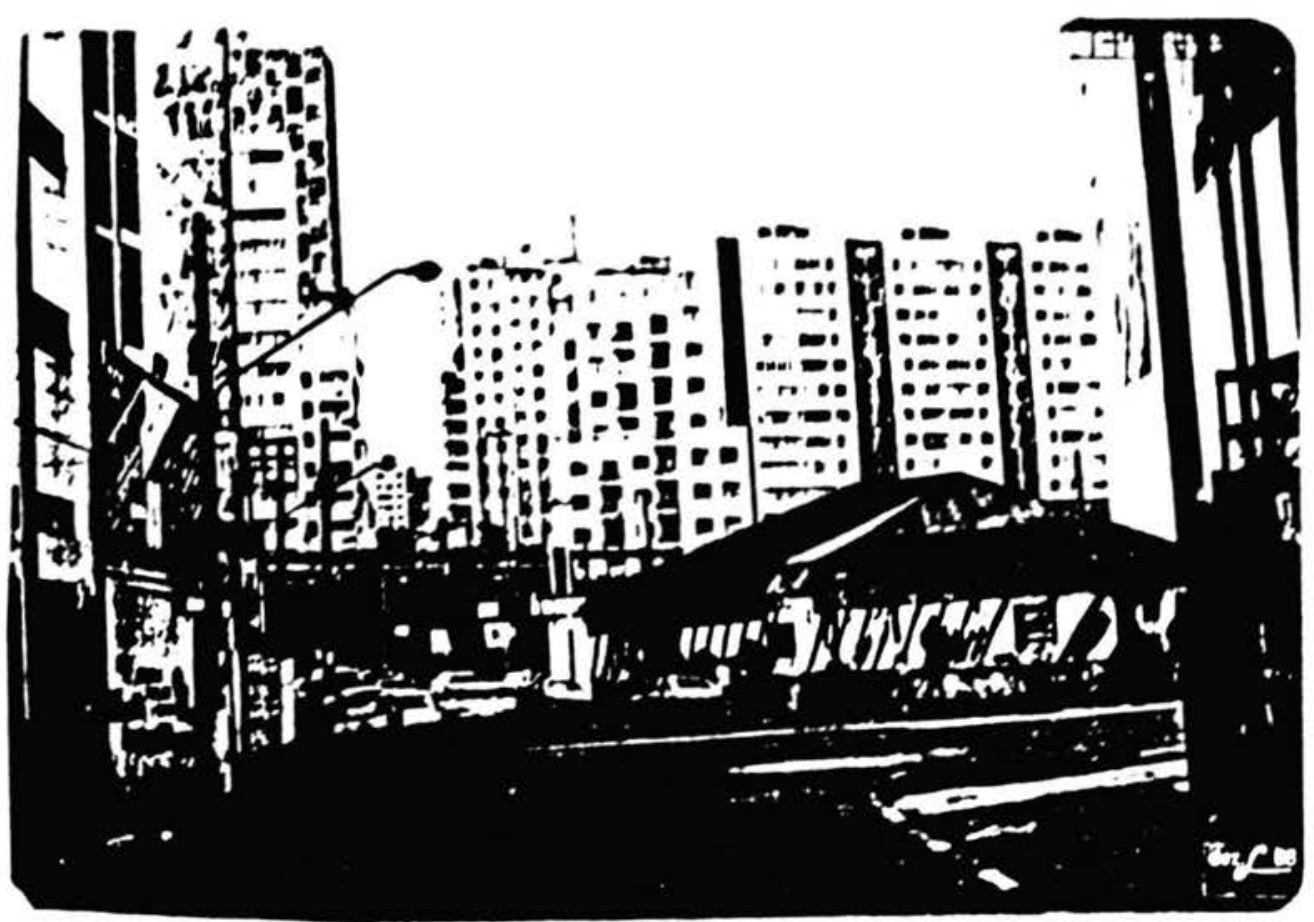

Foto 36: Quadra da Escola de Samba Vai-Vai. Foto que retrata o que foi realizado do projeto. No plano de fundo o elevado da Praça 14 Bis onde localiza-se o ponto de ônibus com o nome da referida escola.

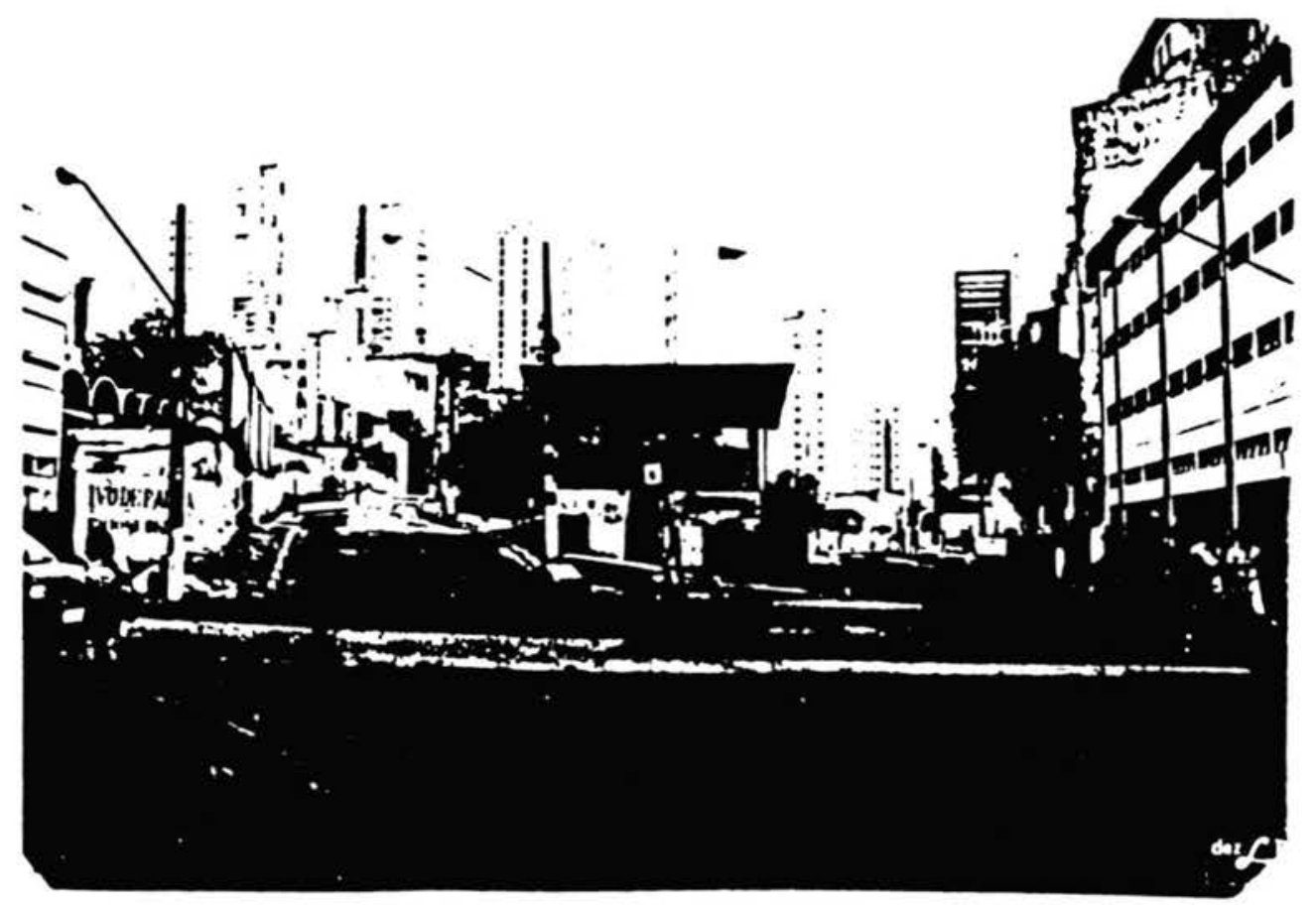

Foto 37: Parte baixa da regiāo da Grota para a qual foi elaborado aquele grande projeto. No plano de fundo da foto o Morro dos Ingleses. (Ano: 1988) 
região da parte baixa da grota, próximo ì praça quatorze Bis nas proximidades de um "gajpão" onde foi instalada a "Escola de Samba Vaj-Vaj", em espaço mujto pequeno e de construção bem precária. Ao redor destes dois equipamen tos, um largo, que com muito esforço pode nos lembrar a presença de uma praça, porém, mesmo assim, abandonada. Mais para o interior da grota, uma pracinha com alguns poucos brinquedos, "lembrando" um parque infantil. No res tantes, nada mais, a não ser, a penetração de alguns prédios novos, porém sem pilotis, voltados a uma população de "classe média". Quanto ao hotel, registramos na . rua Rocha a presença de um prédio do tipo apartament-hotel,po rém não muito grande. Comparando-se o que existe hoje na região baixa da grota com as pretensões daquele projeto, a coisa parece-nos uma "caricatura grotesca" do proposto.

Quanto ao Projeto 13 de Maio, nada foi fei to, a não ser algumas obras, que pelo jeito, foram feitas para substituir alguns elementos pretendidos no projeto,a exemplo da pça. Dom Orione e aquele anfiteatro, "improvisado" como "prótese" junto às escadarias da rua Fortaleza que, ao invés de integrar a paisagem urbana, acabou "mut $\underline{i}$ lando" ainda mais a mesma.

Se a proposta daquele Plano Diretor para o Bela Vista, do qual saíram os dois projetos foi "bem intencionado", seus resultados foram frustradores como propostas de renovação urbana, não somente para o bairro, co mo também para um tipo de experiência tão propagada pelo poder público associado à iniciativa privada. Daqueles ob jetivos todos, os únicos que mais ou menos se concretizaram foram os referentes à consolidação dos restaurantes e construção de novas unidades habitacionais, porém, como 
uma ameaca às camados populares de baixa renda. A propadada "valorizção da paisagem urhana", parecenos, devemos enten der como um processo de "valorização dos terrenos". A pre tendida integração da vida comunitária do bairro, ficou no sonho. No capítulo sobre a Unidade Quebrada tentamos demons trar a desestruturação pelo qual vem passando o bairro e que o Projeto nāo conseguiu resolver; pelo contrário, em certos casos, acentuou mais ainda. Aquelas "obras caricaturescas na paisagem" acentuaram aquelas rupturas.

Neste momento queremos levantar, alguns fatores para reflexão sobre estes desencontros na implantação dos projetos. Como fora colocado pela COGEP-PMSP eles absor veram grandes atençōes do poder público e pelas dimensōes dos Estudos Básicos e dos Projetos - mesmos não concretizados - prováveis fábulas de dinheiro. Não nos foi possível $\underline{i}$ dentificar quanto.

Arrolando-se aqueles objetivos nos preâmbu los do "programa de renovação urbana" do Bela Vista - 28010 e os Projetos Grota e Treze de Maio, podemos sintetizálos em dois grandes eixos de interesses: expandir a indús tria da construçāo civil e reconstituir o bairro como parte integrante da nova metrópole. Colocar o bairro à serviço da cidade como um todo, procurando preservar-1he o caráter cul tural - "na medida do possível". Temos, de um lado, os inte resses do grande capital imobiliário e, do outro, os interesses públicos.

Quando analisados os objetivos das • $\mathrm{grandes}$ construtores e seus interesses sobre os projetos, elas assim se colocaram nos depoimentos para a COGEP-PMSP:

"Os empresários consideram a sub-ārea do Espigão e a parte mais alta da Grota como zo- 
nas que acompanharão normalmente o desenvolvimento das áreas circunvizinhas, principalmente a Av. Paulista, sem a necessidade da adoçāo de medidas modificadoras... no restan te da área, acreditam que nenhum empresário teria coragem de realizar, nas condiçōes atuais, um lançamento isolado em virtude do baixo nivel da vizinhança local, existência de grande número de construçōes deterioradas ... que aliadas às dificuldades, de compra de terrenos de dimensões adequadas... em sua grande maioria de terrenos de pequenas dimensōes (Fig. 13 e 14), desestimularam qualquer incorporador que prefere atuar em outras áreas da cidade que oferecem melhores condi çōes para o sucesso do empreendimento imobiliário... Todos os empresários foram unâni mes em defender a necessidade de reurbanização da regiāo... Alguns mais radicais suger $\underline{i}$ ram a demolição total de tudo até então exis tente, com excessão da sub-ãrea do Espigāo e da Grota" (PR-016, p. 7-3 e 7-4).

Assim, confrontando-se os objetivos do setor empresarial privado - onde fica explicito os interesses de jogarem com o mínimo risco no mercado imobiliārio, buscando a maximização do lucro, com aqueles objetivos definidos pelos projetos de renovação urbana, ou seja: "integração do poder público e a iniciativa privada", revelam-se duas ordens de interesses cuja convergência estará sempre determinada pela "auto-regulação" do mercado imobiliário. Aqui, pá rece-nos claro que aquela expressão - "na medida do possí vel" assume sua verdadeira dimensão: Impossível:

Aquela atitude de "alguns mais radicais", le va-nos a crer que, na base de tal radicalismo, existisse um "consenso" entre os representantes da classe empresarial co 
, i,

(6)

l.

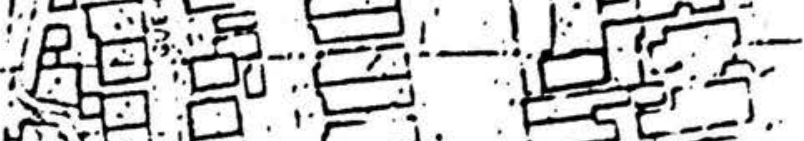

讨 Es

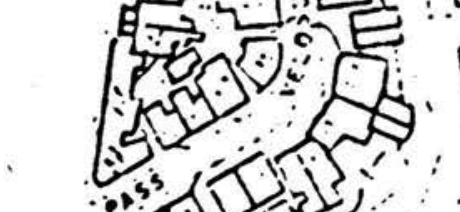

(1)

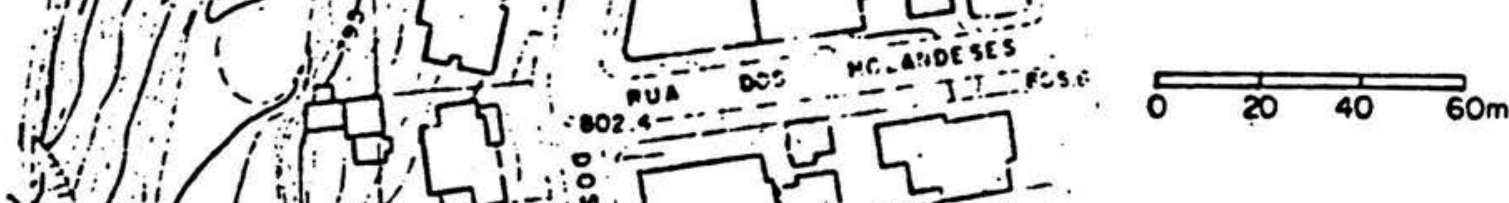

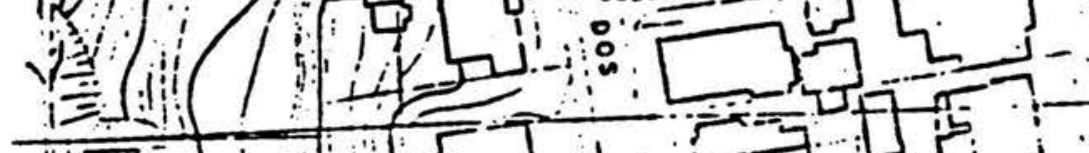

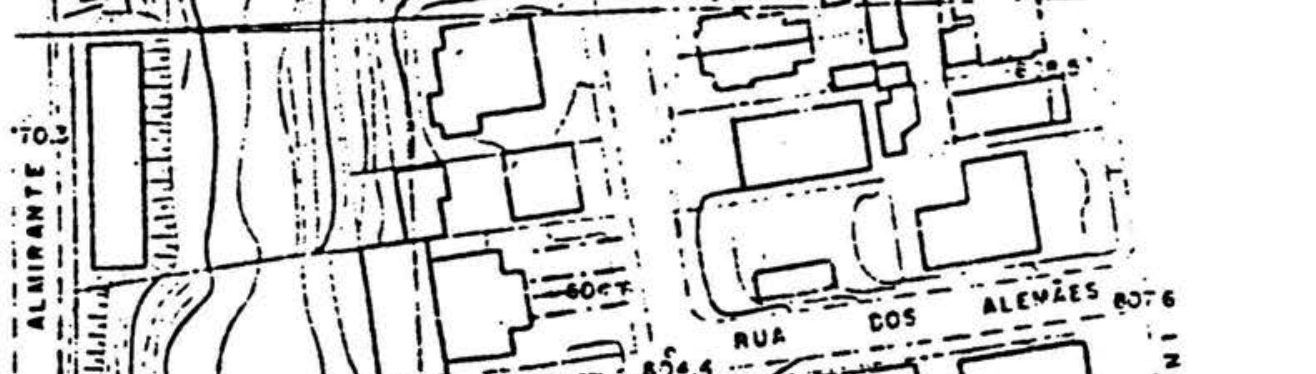

101 ( )

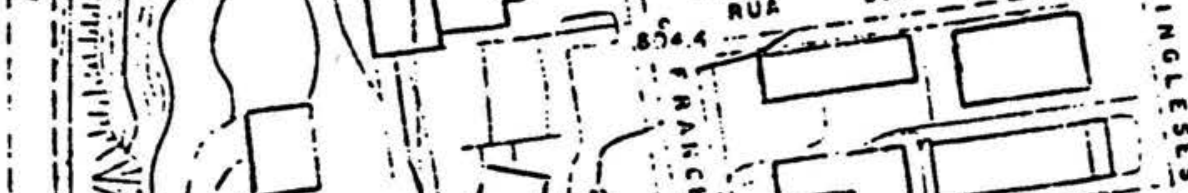

$11 \mid$

(1)

(3)

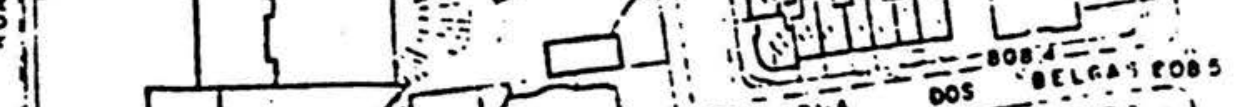

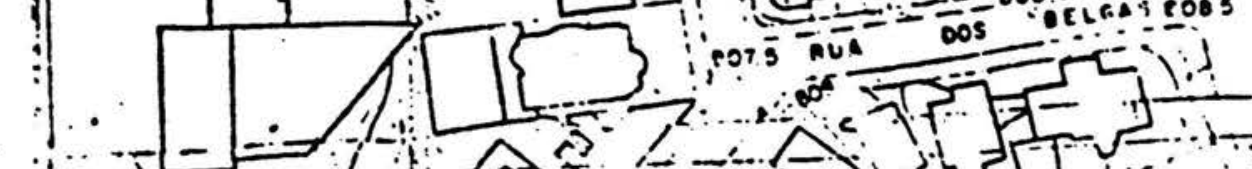

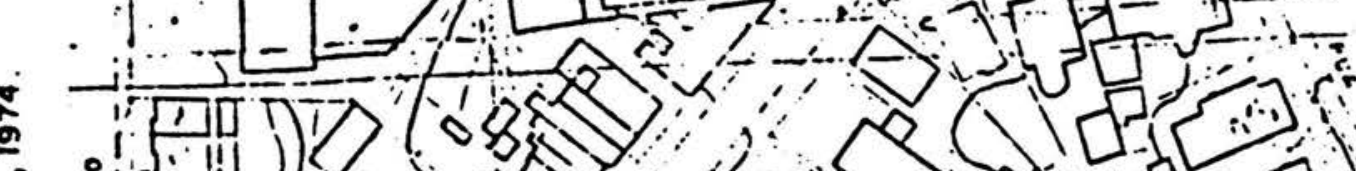

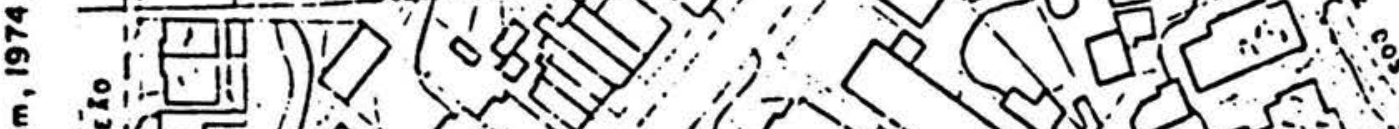

告

吾 


\section{LOTES - 13 DE MAIO - ÁREA B3}
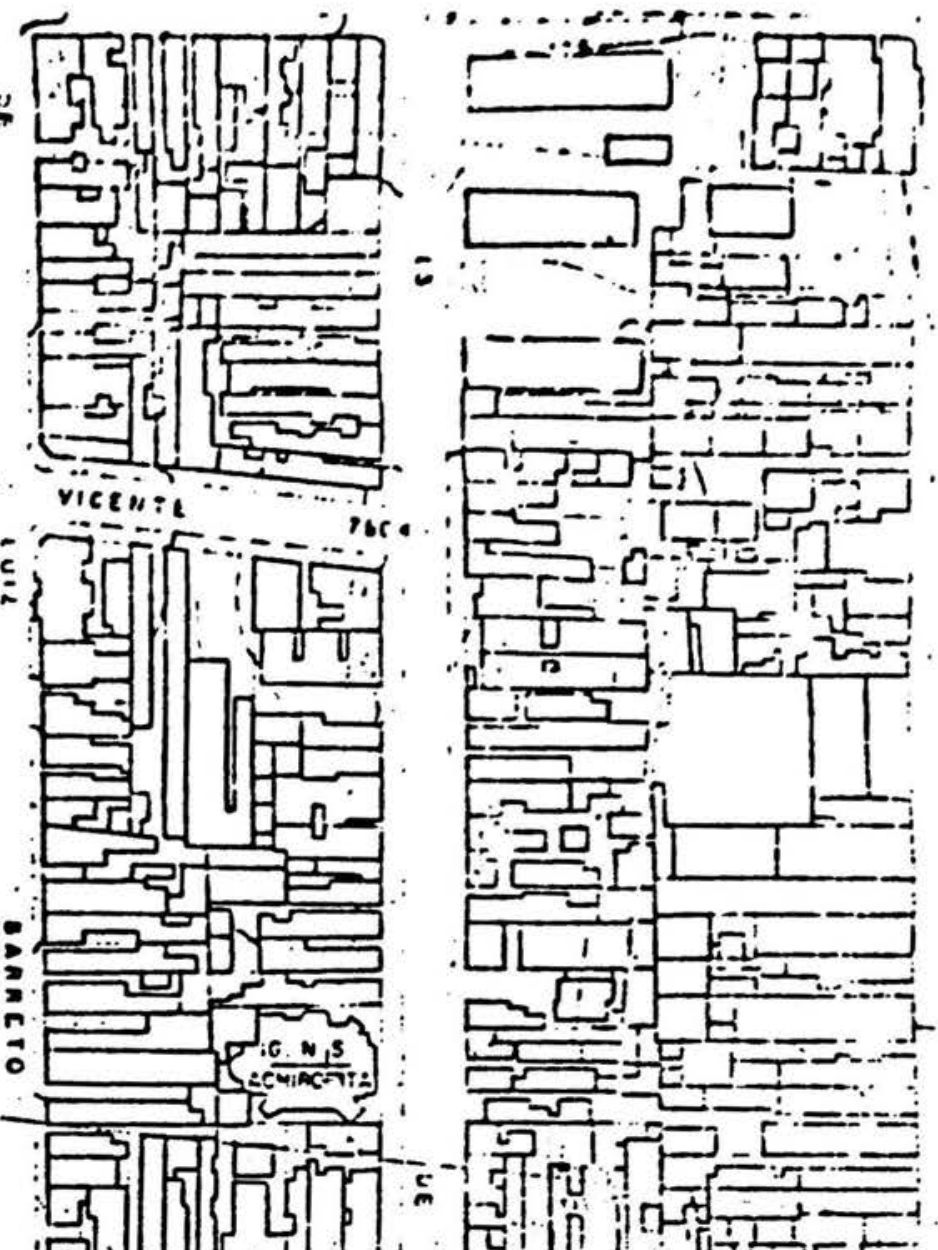

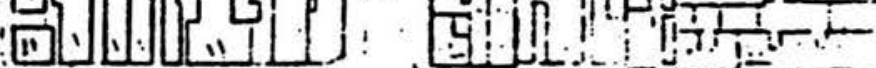

CONSELTETIẼ

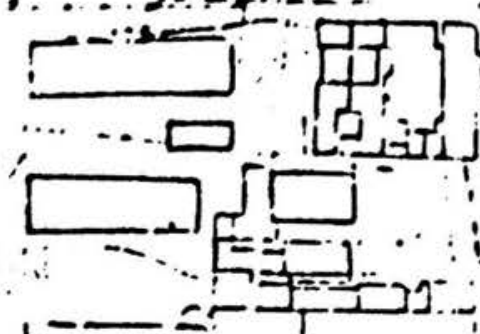

$1=2$

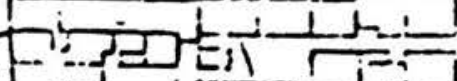
:- : (1)
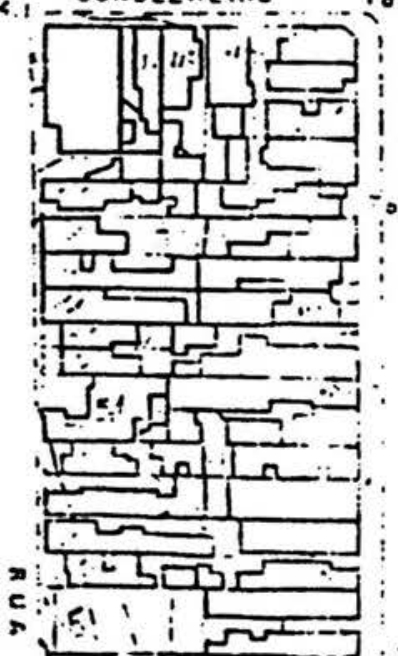

$2 \quad 20 \quad 40 \quad 60 \mathrm{~m}$

$\therefore$ C.

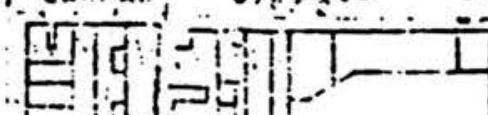

En :
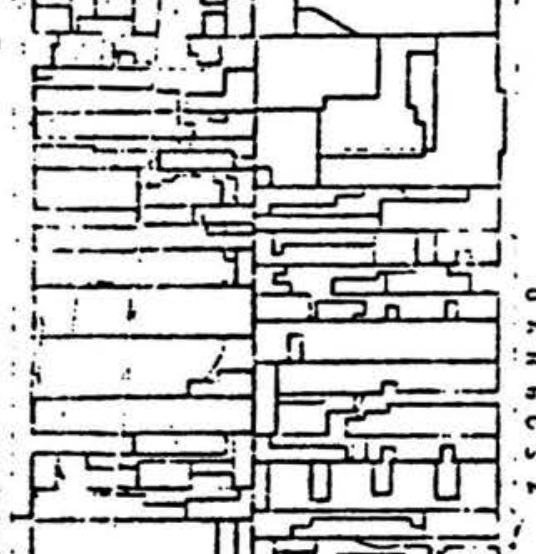
S :U1 12-2 गीL

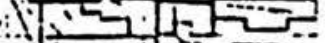

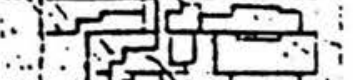
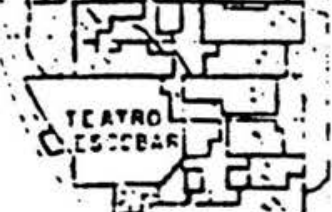

$110 \mathrm{U}$

:

L..

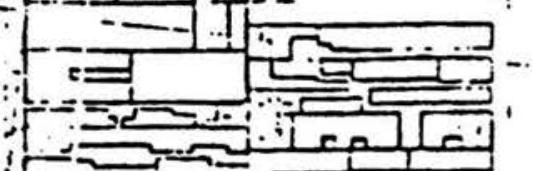

if

7 .

Fonte Georom, 1974

$\ldots a$ con:

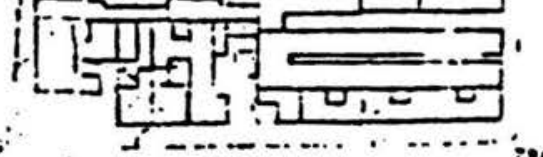

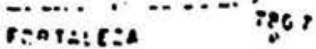


mo um todo. Aquela proposta de demolişão para toda a parte do "antigo Bexiga", pressupunha, obviamente; deixar intacta toda a infra-cstrutura básica dos serviços e equipamentos urbanos, pressupunha "limpar" somente os terrenos. Estes fatos nos permitem compreender a verdadeira essência do urbanismo capitalista, pelo menos em países como o nosso. A frustrada proposta daqueles projetos para o bairro deve ser entendida como um exemplo das propostas de renovação urbana e seu "destino", quando não são capazes de "despertar" os interesses dos "gordos lucros". A colocação de que "nenhum empresário teria coragem de um lançamento $\underline{i}$ solado" leva-nos a crer que por detrás disto estava e está a tendência da área em ser alvo dos interesses das grandes corporaçōes imobiliárias. Onde as mesmas querem "carta branca" para especular com os terrenos. Fica assin mais claro porque os projetos não se concretizaram. Como sempre, as iniciativas públicas que estabeleçam algum objetivo de cunho social que não estejam nos limites da "lucratividade máxima" do capital, estão fadadas à frustração.

Hoje, quando trava-se toda aquela polêmica sobre as modificaçōes do PDDI e daquela Comissão de 20neamento, onde se aponta a pressão das grandes construto ras como elemento ativo no destino da renovação urbana de São Paulo, a coisa torna-se mais transparente. Para estas é impor tante "libertá-las da camisa de força" de qualquer forma de direcionamento sobre sua ação no mercado imobiliārio. A "fluidez" da proposta do novo PDDI, parece "agradar" as mesmas. Contra este novo PDDI, como vimos, colocaram-se muitos segmentos da sociedade civil e política. Caso o mes mo venha a ser aprovado, São Paulo se transformará num ver dadeiro "canteiro de obras". Não somente o Bela Vista esta 
rá fadado a transformar-se neste "canteiro" como os demals bairros centrais da cidade. Sobre o assunto, assim se cxpressou outro periódico da cidade como resposta a atual tendência de adensamento dos bairros centrais: "Ou Pinheiros reage ou vira "paliteiro". (Gazeta de Pinheiros, 8/7) 88).

Terminado o "ciclo" dos Projetos da Grota e da Rua Treze de Maio - engavetados pelo poder público da municipalidade de São Paulo, abriu-se outro. Em 8/12/87, ○ Secretārio da Habitação e Desenvolvimento Urbano encaminhou ao Prefeito de São Paulo a solicitação da criação de uma comissão para a "viabilização do concurso público nacional para a renovação urbana e preservação do bairro do Bexiga" (Publicado no D.O.M. em 10/12/87). Assim, ficaram definidos os "novos" objetivos para o "Novo Plano de Renovação Urbana": "0 Plano para a Renovação Urbana e Preserva ção do Bairro do Bexiga, terá como objetivo, o pleno desenvolvimento da potencialidade e das características da área, adequando a utilização e ocupação do solo à valoriza ção e preservação do seu Patrimônio Ambiental Urbano, compatível com o possível adensamento da região, tendo em vis ta a sua excepcional condição de localização. Especial atençāo deverá ser dada aos interesses dos moradores e das atividades instaladas no bairro" (D.0.M. 10/12/87). Desta vez, o comprometimento com a política de adensamento fica claro, mesmo após todos aqueles movimentos travados sobre os inconvenientes do adensamento para os bairros centrais. A demagogia mais uma vez está presente. Mais uma vez em nome das "tradiçōes e defesa" dos interesses populares escondem-se os interesses do grande capital. Para o tal concurso, foram conclamados setores representativos dos inte 
resses privados da socjedade.

Os dols projetos da década de setenta foram engavetados. 0 bairro em transe, revelando um profundo processo de desmembramento, pouco terá para ser efetivamente integrado como "Bexiga" pelo projeto vencedor no concurso (nesta altura da tese não nos foi possível ter acesso ao resultado do mesmo). Até que ponto aquelas lideranças conse guirão garantir a sobrevivência das suas atividades é uma questão em aberto. Pela generalização e demagogia dos novos objetivos, tudo nos lembra aqueles projetos do "antigo ciclo". Nada mais oportuno no momento do que invocar aquela introdução feita por Marx na sua obra - 018 Brumārio de Luiz Bonaparte:

"Hegel observa em uma de suas obras que todos os fatos e personagens de grande impor tância na história do mundo ocorrem, por assim dizer duas vezes. E esqueceu-se de acres centar: a primeira vez como tragédia, a segunda como farsa" (Marx, p. 3).

Quando concluíamos a redação deste capítulo tivemos acesso a uma manchete de jornal que nos chamou a atenção. Ela remetia-nos a uma reflexão sobre aquela nota da Folha de S. Paulo do dia 15/4/74 (anteriormente citada nes te capitulo). A manchete era a seguinte: "Edifícios cada vez mais altos poderão, dentro de pouco tempo, começar a surgir em diversas äreas da cidade, especialmente nas mais valorizadas e de uso estritamente residencial, prejudicando a qualidade de vida dos seus moradores. Isto porque deverá ser aprovado nesta semana, por decurso de prazo, O Plano Di retor, que amplia as chamadas "operaçōes urbanas" (Shopping News, $30 / 10 / 88$ ). No mesmo dia, a manchete colocava em forma de advertência: "Bixiga: no alvo do "adensamento". A nota 
da Folha de São paulo remete-nos à lembrança de projetos frustrados e ameaças que entāo se delinearam. A do shop ping News não mais à perspectiva de "conflitos", mas ao ing cio, talvez, de um novo "Bexiga - Ano zero". 
6. CONCLUSAOO

o Bexiga de hoje está longe de ser aquela totalidade espaço temporal que fora no passado. Seu italia nismo, como pudemos registrar, tanto pelo movimento de saida, pelas mortes e pela redução radical na entrada de novos contingentes de italianos, praticamente desapareceu enquanto um componente sócio-cultural do mesmo.

Os ítalo-paulistas são também cada vez menos numerosos. A influência deixada tanto pelos italianos como pelos oniundi nos hābitos e na paisagem arquitetônica jā foi praticamente descaracterizada. A verticalizaçāo e a invasāo do bairro por todas aquelas novas atividades contribuiu para esta descaracterização. 0 pouco que sobrevi veu de forma mais bem caracterizada encontra-se no interior da área por nós chamada de $\underline{B} 3$, mesmo assim, tendo per dido a maior parte de sua autenticidade. Aquilo que pode ria lembrar de forma mais autêntica as origens italianas do Bexiga foi transformado em "sucata" para dar origem a um "produto" - aquela "feira de diversões".

0 bairro vive hoje a coexistência de duas atividades ligadas ao grande mercado da metrópole paulista na: uma representada pelo setor de cantinas e congêneres que guarda nas origens relaçōes com a tradição do bairro; a outra, representada pelas casas de diversōes, desdobrando-se em fortes relaçōes com os teatros e outras mais. $\mathrm{Na}$ verdade estas duas atividades colocam-se de uma certa 
forma, como antagônicas para a major parte da população tra dicional do Bexiga. As primeiras, mistificadas ou não, guar dam raizes com a história do bairro. Representam lugares on de a frequência, segundo depoimentos dos moradores tradicio nais, é de "familias" e de "gente de respeito", mais próximo do que fora antigamente. Elas lembram melhor o "antigo" Bexiga. As segundas, ao contrário, representam o "novo", a imagem do "forasteiro", principalmente as casas de música e bar. Os pequenos bares de encontro são "estigmatizados" pela população tradicionalista como o símbolo de "marginalida de". Eslas atividades representam os "intrusos", verdadei ros "usurpadores" daquele tradicionalismo. As mesmas surgiram após aquele período das grandes transformações urbanísticas. Com elas introduziu-se uma "nova forma de vida" para - bairro, aquelas diversões transformadas em mercadorias e vendidas para a cidade.

O TBC - Teatro Brasileiro de Comédias, iniciou a partir da sua inauguração um impulso para que o Bex $\underline{i}$ ga se transformasse na "Broadway" paulistana. Aquelas casas e teatros que entraram posteriormente, consolidaram a "novo ciclo para o bairro", apagando o outro, o do "italianismo e das ruas comunitárias".

A nova vida "boêmia" trouxe consigo, tambēm, naqueles "embalos de finais de semana" a possibilidade de se transformar o pedaço noutro "pesadelo" para os antigos moradores, ou seja: lugar de passagem de drogas, trazendo com muita frequência a presença da polícia, criando, assim, um clima de "violência" para um lugar que outrora primava pela tranquilidade. Este fato foi exaustivamente denun ciado naqueles depoimentos. Segundo eles, a "intranquilida- 
de" aumentou com a entrada das casas de diversōes e os bares de encontro.

A "indústria do lazer" e a "indústría da construção" tanto de apartamentos como daquelas obras de reurbanização, estimuladas pela expansão capitalista, destruíram as condições de sobrevivência da função residencial compatível com uma boa qualidade de vida urbana. 0 aden samento, o aumento do fluxo de automóveis, a perda da escala arquitetônica pelo "esmagamento" das antigas casas en tre os "espigões", foram as grandes responsáveis pela desqualificação do lugar para moradia.

Hoje, a especulação imobiliāria, umpulsionada pelo "progresso" metropolitano, fez com que aqueles proprietärios dos antigos casarões entrassem no jogo da es peculação, tanto dos aluguéis, como no jogo da valorização dos terrenos, pouco se importando com a conservaçāo dos imóveis, os quais, enquanto ocorre a valorização dos terre nos, cada vez mais se transformam em cortiçōes. A casa como bem de uso, que outrora representou um fator de afirmação social a qual se "adornava" com belos frontispícios,es tatuetas e portões de ferro artisticamente trabalhados,de $\underline{i}$ xou de existir como "obra do artesão". 0 que ficou foram ruinas.

As investidas das relações capitalistas de produção expressas tanto pelos avanços da indústria da construção civil como pela entrada de todas aquelas novas funçōes terciārias, informais ou não, destruiram aquelas relações muito próximas do "ideal pompeiano" já descrito anteriormente. 0 italianismo e o tradicionalismo foi "emba 
1ado" e vendido como "cartão postal". A área B3 onde isto aconteccu mais fortemente, serve de exemplo. Não nos é possivel perceber o bairro como uma unidade integrada. Cada area passou a ter uma dinâmica diferente da outra. A área do alto da grota por origem histórica sempre esteve desvincula da do restante do bairro. Porém, aquilo que chamamos de núcleo histórico desmembrou-se todo. O núcleo do Piques, como vimos, integrou-se ao CBD; a $B 3$ passou a ter vida própria como área onde ocorreu aquela "revitalização" e sobre a qual as lideranças empenham-se em "preservar".

O Bexiga acabou adquirindo um novo perfil, uma nova identidade. Casa e rua passaram a compor uma nova dialética. Inverteram-se os papéis. Seus moradores mais antigos sentem-se estranhos dentro do bairro. Revelam um sentimento de perda, pelo que parece, irreversivel. Sentem que - bairro perdeu sua identidade. Para os novos moradores, a maioria revela um sentimento de indiferença com o destino do bairro frente ao que o mesmo jā fora. Um comportamento prōprio de quem nunca tivera "relação afetiva" e nunca terá com lugar nenhum - são os despossuídos da vida. No caso do Bexiga, a grande maioria de nordestinos.

Se é difícil dizermos quantos cortiços tem hoje o Bexiga, não o é dizer que os mesmos dão uma tônica marcante à sua paisagem urbana, revelando claramente con trastes com aquilo que fora no passado do bairro. Os mesmos, apesar de se encontrarem por toda a área do "núcleo histórí co", estão mais concentrados na ārea $\underline{B 2}$ e ausentes da área do alto da Grota.

Na medida que sua população tradicional re- 
Colrat rasbes de deterioração do estado físico da grande parto das residencias do bairro, preferindo achar um "bode explat8r10" para o fato, neste caso o nordestino, juntament com uma liderança apoiada em instituiçōes de defesa das tradiçōes mal estruturadas, caracterizando-se por um grande "amadorismo", as formas de luta contra as forças do sistema que gradativamente foram destruindo as raizes culturais do bairro, mostraram-se ineficientes. Além do amadorismo, de vemos destacar a maneira nem sempre democrática da maioria daquelas lideranças em conduzir as lutas frente a comunidade, fato que pudemos contatar pelos depoimentos.

Cada vez mais torna-se impossivel pensarmos em resgatar aquelas antigas relações sociais no bairro e re cuperar as condições físicas da maioria daqueles casarões que se transformaram em cortiços - fruto do descaso dos seus proprietários e do poder público mais interessado em aliar-se aos grandes investimentos da indústria da construção civil construíndo novas unidades de moradia, mais caras e estimulando o apetite do mercado imobiliário. 0 poder público mostra-se pouco inclinado a intervir neste espaço e recuperá-10, sem partir para aquela "limpeza dos terrenos", conforme sugeriram as companhias construtoras. Quando o mes mo interviu no Bexiga foi para mutilá-lo com todas aquelas obras de reurbanização, ou então com aquelas Leis de Zoneamento que se mostraram incapazes de conter o contínuo adensamento que vem se verificando no interior do mesmo.

As condições sócio-econômicas que marcaram a evolução da economia brasileira com todas sequelas para o empobrecimento da maioria da sociedade brasileira, jogou no 
ostracismo e no "nomadismo" uma grande parte de sua população, fato a qual está associada a chegada dos contingentes de nordestinos para os cortiços do Bexiga, quando, contradí toriamente, este bairro recebia enormes quantias em dinheiro para sua adaptação ao moderno sistema viário metropolita no; modernização necessária para o grande capital. Assim,vi mos que a intervenção do poder do Estado veio aumentar as contradiçōes e piorar as condiçōes de vida da maioria da po pulação que morava no bairro. "Impotência" ou "descaso", es te tipo de planejamento revelou-nos a verdadeira natureza desta forma de urbanismo.

Assim, podemos aqui, mais uma vez refletir sobre os Planos Diretores feitos para o bairro. Como os mes mos revelaram-se inoperantes e perdulários. 0 Projeto da Grota e $\circ$ Projeto Rua 13 de Maio, não se concretizaram sendo engavetados. Tudo isto faz da experiência do planejamento e reurbanização do Bexiga até hoje um exemplo da "inconsequência" da política do planejamento urbano no país. Nossos estudos feitos sobre estes projetos de reurbanização pa ra o bairro do Bexiga e a maneira como foram conduzịdos,per mite-nos concluir que os mesmos foram orientados da forma mais autoritária possivel. Este autoritarismo revelou-se tanto por parte do poder público como do lado daquelas 1ideranças, que outra coisa não viam além da possibilidade de lucros preservados na recuperação do bairro. A comunidade como um todo ficou do lado de fora, ou então foi chamada pa ra legitimar fatos $j a ̄$ consumados.

Podemos afirmar que existe pouca transparên cia nos discursos destas lideranças como nos preâmbulos daqueles projetos. 0 que deve ser preservado ou não, não fica 
cjaro. Os discursos oficiuis quando se referem às tradiçós do bairro o fazem sempre de forma evasiva. Quanto aos dis cursos daquelas lideranças, a coisa não muda muito.

Tudo is to nos permite levantar a seguinte pergunta: - Até que ponto ós elementos por nós apontados que sobreviveram do tradicionalismo do Bexiga, "mistifica dos" ou não, conseguirão sobreviver aos avanços da indús tria da construçāo civil inserida no interior do processo de adensamento e crescimento horizontal da metrópole? Ao mesmo tempo nos perguntamos até quando as cantinas e as casas de diversões, que no conjunto do terciário do Bexiga ré presentam as atividades de maior concentração, também conse guirão aỉ se manter? Mesmo representando um terciārio por nós considerado como "superior" estas atividades não nos parecem garantidas em sua sobrevivência frente aquelas investidas da indústria da construção civil e do processo de "modernização" que ocorre com o terciário no interior do bairro. Lembremos o que vem acontecendo com a área B1 e me mo com as demais.

Se o Bexiga é hoje a expressão de um bairro em "transe" onde a $\underline{B 3}$ parece representar o lugar pelo qual a luta pela sobrevivência é mais forte, onde o "imaginário" e a "mistificação" representam na atual etapa da histōria do bairro, depois dos anos de "catástrofe", uma possibilida de de luta por este tipo de sobrevivência, cabe aqui, uma outra pergunta: - A quem interessa essa luta? A resposta não nos parece difícil: aos grupos que exploram a "indús tria do lazer". Porém, como vimos, nesta luta outros também estão envolvidos, são os membros da comunidade representati va do tradicionalismo que muitas vezes, de forma ambígua, se 
colocam no interior desta luta. Estes, ao mesmo tempo que se colocam na luta pela preservação das tradicões e de sua moradia como um bem de uso, aquele "refúgio" que sobrou do "naufrágio" não negam a perspectiva de uma venda desta moradia por um "bom preço". Ao mesmo tempo que se colocam do lado dos donos de "casas de diversōes" e cantinas, "blasfemam" contra a entrada de forasteiros, trazidos pelo cres cimento daquelas atividades. Assim, não é difícil, admitir que estes membros da comunidade não resistirão muito a pas sarem para o "outro lado", ou seja: "fazerem um bom negó cio" junto àquelas companhias imobiliárias.

Aquele ideal "pompeiano" de bairro não está perdido somente para o Bexiga. Hoje, as relações sociais, que determinam a vida nas äreas metropolitanas e mesmo fora delas, impedem que o mesmo sobreviva. Se em outros tempos, apesar das diferenças de classes, os indivi duos conseguiam definir relaçōes societárias capazes de fortalecer a vida comunitāria, como foi o caso do Bexiga , hoje no interior da metrópole, onde as diferenças de classes são cada vez mais acentuadas e o processo de estratif $\underline{\underline{i}}$ cação no interior destas últimas é cada vez mais complexo, definindo comportamentos e ideologias tão diferenciadas, a vida comunitāria acaba cada vez mais se restringindo, como já havíamos afirmado, a processos de interações "atomiza dos" e "momentâneos".

Assim, o bairro guarda, alēm das diferen ças de classes uma diferenciação cada vez mais acentuda no nivel da estratificação. Ideologias que se aproximam e dis tanciam independentemente da condiçāo de classe. As "Socie dades Amigos de Bairros" apresentam-nos bons exemplos: pa- 
trões e empregados apresentam-se como "aliados" em certos niveis de reivindicações e, em outros, em polos antagônicos, como quando militam, por exemplo, em partidos com propostas de reurbanização diferentes para o bairro.

Na medida em que o Bexiga é hoje um bairro onde o processo de metropolização gerou não somente uma redefinição acentuada nas suas formas de uso do solo mas, tam bém, na sua composição e processos sócio-culturais, qualquer movimento de luta pela defesa das tradições do bairro deverá estar sendo determinada por este complexo sistema de estratificação social.

Aquela ideologia do "Bixiga" não deve ser estendida à toda comunidade tradicionalista do bairro, tampouco à população do bairro como um todo. Como vimos, alguns dos depoimentos de membros daquela comunidade coloca ram a questāo do italianismo e qualquer tentativa de fażê10 ressurgir como algo condenado ao fracasso.

E uma ideologia que "serve" para todos os fins. Para reforçar os anseios daquele "bloco histórico";pa ra designar o bairro "boêmio" e para muitos o bairro das "drogas".

Lembrando Agnes Heller no que nos diz sobre o processo dinâmico da história, sobre as mudanças. das estruturas sociais, poderemos compreender melhor o que acon teceu com o Bexiga. Certas estruturas, que em determinados momentos da história foram significantes, "submergiram nas profundezas, para aí continuarem uma vida inessencial do ponto de vista social global". 
AUZELLE, Roberto

BOSI, Ecléa

BRUNO, Ernani Sil-

va

BACHELARD, Gaston

BETTANINI, Tonino

BENJAMIN, Walter

CORDEIRO, Helena Kohn

Claval, Paul

CARElli, Mário
Chaves do Urbanismo. Ed. Civilização Brasileita, 1972, Rio de Jane ro.

Memória e Sociedade - Lembrança de Veltho. EDUSP, 1987.

História e Tradições da Cidade de São Paulo, Livraria José olímpio, 1953, Rio de Janeiro.

A Poética do Espaço in Os Pensadores, Abril Cultural, 1978, São Pau 10.

Espaço e Ciências Humanas, Ed. Paz

e Terra, 1982, Rio de Janeiro.

Paris, Capital do Século XIX. A Paris do Segundo Império em Baudelaire in Walter Benjamin, Sociologia. Coleçāo Grandes Cientistas So ciais. Editora Ãtica, 1985. São Paulo.

O Centro da Metrópole Paulistana Expansão recente. Instituto de Geo grafia, USP, 1980.

Evolución de Geografia Humana. Oilos-Tau, S/A., 1974, Barcelona.

Carcamanos e Comendadores. Ed. At $\underline{\underline{i}}$ Ca, 1985. São Paulo. 
ERVH:LIATIJ, Luigi e

CANNAVINI, ROBETto

ERMAN, MARSHALL

:UVILLIER, ARMAND

JERRUAU, Max

ミCO, Umberto

I dem

ECKARDT, Wolf Von

ENGELS, Friedrich

FRAGATA, S.J. Julio

FRIEDMANN, George
Bolonha: Pot que o Centro Histótjco? In Marxismo c Urbanismo Capjta - lista.livraria Ed. Ciências Huma nas, 1979, São Paulo.

Tudo Que é Sólido Desmancha no Ar. Aventura da Modernidade. Editora Schwarcz Ltda., 1987, S.P.

Sociologia da Cultura. Editora Glo bo. 1975. Porto Alegre.

Tratado de Geografia Humana. Edito rial Vicens-Vives. 1964. Barcelona.

Viagem na Irrealidade Cotidiana. E ditora Nova Fronteira, 1984, Rio de Janeiro.

Como se faz uma Tese. Editora Pers pectiva, 1983, São Paulo.

A Crise das Cidades - Um lugar para Viver. Zahar Editores. 1975,Rio de Janeiro.

A situação da Classe Trabalhadora na Inglaterra. Ediçōes Afrontamento. 1975. Porto.

A Fenomenologia de Husserl como Fundamento da Filosofia. Livraria Cruz, 1959. Braga.

Sete Estudos sobre o Homem e a Téc 
nica. Difel. 1968. São Paulo.

FilHo, Nestor Goulart Quadro da Arquitetura no Brasil. Reis Ed. Perspectiva, 1970, São Paulo.

GARAUDY, Roger

GRUNSPUN, Ha im

GRAMSCI, Antonio

GIUDUCCI, Roberto

GEORGE, Pierre

HARVEY, David

HEGEL, Guillermo

Federico

HILAIRE, Saint

HOMEM, Maria Cecilia Naclério

HELLER, Agnes
O Pensamento de Hegel. Moraes Edi tores. Lisboa, 1971.

Anatomia de um Bairro. Livraria $\underline{E}$ ditora Cultura, 1979. São Paulo.

Obras escolhidas. Ed. Martins Fon tes Editora Ltda. 1978, São Paulo.

A Cidade dos Cidadãos, Ed. Brasiliense. 1980, São Paulo.

Compêndio de Geografia Urbana, Ediciones Ariel, 1964, Barcelona.

A Justiça Social e a Cidade. Huci tec, 1980. São Paulo.

Filosofia del Espiritu, 1968, Bue nos Aires.

Viagens à Província de São Paulo. Livraria Martins Editora.

Higienópolis - Grandeza e Decadên cia Bairro Paulistano. DPH-PMSP 1985.

O Cotidiano e a História. Paz e Terra, 1985. Rio de Janeiro. 
JUN(;, Carl

JUNIOR, Caio Prado

LUCENA, Célia Toledo

Idem

LANGENBUCH, Jurgen

Richard

LIMA, Sérgio de Souza

LOJKINE, Jean

LUKACS, George

LENINE, V. I.

LEFEBVRE, Henri
O Homem c scus Simbojos. liditora Nova frontcira, 1964. Kio de Janeiro.

A Cidade de São Paulo. Brasiliense. 1983. São Paulo.

Bixiga, Amore Mio. Editora Pannartz, 1981. São Paulo.

Bairro do Bexiga - A Sobrevivên cia Cultural. Ed. Brasiliense. 1984. São Paulo.

A Estruturação da Grande São Pau10. IBGE, 1971 .

Processo de Urbanização e Política, in CEDEC. Paz e Terra, 1978 , Rio de Janeiro.

A Anālise Marxista do Estado, in Espaço e Debates. Cortex Editores. Ano $1, n^{\circ} 1$.

Prolegomenos a una Estetica Marxista. Editorial Grijalbo S/A. 1965. Mexico.

Materialismo e Empirocriticismo . Editorial Estampa. 1975. Lisboa.

O Direito à Cidade. Ed. Documen tos. 1969. São Paulo. 
1.1:HIBVRI:, Henti

Idem

MARTINS, José de Souza

MENDES, Renato da

Silveira

MARZOLA, Nadia

MORA, José Ferrater

MENDES, Maria

Celestina Teixeira

MUMFORD, Lewis

MIR, Mercedes Tatjer posição contra os Tecnoctatas. Ed. documentos litda. 1969. São Paulo.

La Presença y la Ausencia - Contr $\underline{1}$ buición a la Teoria de las Repre sentaciones. Fondo de Cultura.1983, Mexico.

Conde Matarazzo - 0 Empresārio e a Empresa. Hucitec. 1976. São Paulo.

Bairros da Zona Sul e os Bairros $\underline{0}$ cidentais, in a Cidade de São Pau10, Estudos de Geografia Urbana. Companhia Editora Nacional. 1958 , São Paulo.

Bela Vista. DPH-PMSP. 1985. São Paulo.

Diccionario de Filosofia. Editorial Sudamericana. 1965. Buenos Aires.

Brās. DPH-PMSP. 1985. São Paulo.

Perspectivas Urbanas. Ed. Emecé. 1969. Buenos Aires.

La Barceloneta del Siglo XVIII al Plan de la Ribera. Ediciones Sa turno. 1985. Barcelona. 
MARX, Kar 1

Idem

I dem

I dem

MACHADO, Alcantara.

MARICATO, Ermínia

COELHO NETTO, J.

Teixeira

OLIVEIRA, Francisco

Idem
O Capltal. Volume I. Livro I. Editora Civilização Brasileira, 1974. Rio de Janeíro.

La Ideologia Alemana. Ediciones Grijalbo S/A. 1970. Barcelona.

0 18 Brumário e Cartas a Kugelman. Paz e Terra. 1969. Rio de Janeiro. Teses Contra Fuerbach, in Os Pensa dores Editora Abril Cultural. 1978, São Paulo.

Brās, Bexiga e Barra Funda - Notícias de São Paulo. Imprensa Oficial do Estado. 1983. São Paulo.

Autoconstruçāo, a Arquitetura Possivel, in A Produção Capitalista da Casa e da Cidade no Brasil Industrial. Ed. Alfa-Omega. 1979.Sāo Paulo.

A Construção do Sentido na Arquite tura. Ed. Perspectiva. 1984. São Paulo.

A Economia da Dependência Imperfei ta. Ed. Graal. 1977. Rio de Janeiro.

Acumulação Monopolista, Estado e Urbanizaçāo: A Nova Qualidade do Conflito de Classes, in CEDEC, Paz 
e Terta, 1978. Rjo de Janefro.

VIEIRA PINTO, AlvaTO

QUEIROZ, Maria Isaura

Pereira

ROSENTAL, M. e IUDIN, P. F.

RODRIGUES, Jorge

Martins

SANTOS, Carlos Nelson

D. dos. (Coordenador)

SANTOS, MILTON

SCARLATO, Francisco

Capuano

SEABRA, Manuel e

RODRIGUES, A.M.
Ciência existêncía. Ld. Paz c Terra. 1969. Rio de Janeiro.

Bairros Rurais Paulista. Livraria Duas Cidades. 1973. São Paulo.

Dicionário Filosófico. Editorial Estampa, 1972. Lisboa.

São Paulo de Ontem e de Hoje. Departamento da Cultura da Prefeitu ra de São Paulo. Imprensa Oficial do Estado. 1940. São Paulo.

Quando a Rua Vira Casa. Projeto Editores Asociados Ltda. 1985.Sāo Paulo.

Pobreza Urbana. Ed. Hucitec, 1978. São Paulo.

Metropolização de São Paulo e TeI ceiro Mundo. Ed. Iglu. 1987. São Paulo.

Habitação e Espaço Social na Cidą de de São Paulo, in Boletim Paulista de Geografia. AGB, n. 64 . 1987. São Paulo.

SINGER, Paul
Movimentos de Bairro, in Sāo Pau10: O Povo em Movimento. Ed. Vozes. 1982. Petrópolis. 
SARTRE, Jean Paud

TRICART, J.

TUAN, Yi-Fu

VAZQUEZ, Adolfo

Sanches

VELHO, Gilberto

ZEVI, Bruno

WILHEIM, Jorge

Idem

WITH, Lewis
A Imaginação. Difel. 1964. Sĩo paulo.

Cours de Géographie Humanine. L' Habitat Urbain. Centre de Documen tation Universitaire.

Topofilia - Um Estudo da Percep ção, Atitudes e Valores do Meio Ambiente. Difel. 1980. São Paulo.

Filosofia da Praxis. Ed. Paz e Terra. 1977. Rio de Janeiro.

-A Utopia Urbana - Um Estudo de An tropologia Social. Zahar Editores. 1978. Rio de Janeiro.

Saber Ver a Arquitetura. Ed. Mar tins Fontes. 1978. São Paulo.

São Paulo, Metrópole 65. Difel. 1965. Sāo Paulo.

Projeto Sāo Paulo - Proposta para Melhoria de Vida Urbana. Paz e Terra. 1982. Rio de Janeiro.

0 Urbanismo como Modo de Vida, in o Fenômeno Urbano. Zahar Editores. 1967. Rio de Janeiro. 
Publicações Edjadas por Orgẽos Púbjicos

CEPAM - Fundação Faria Avaliação do Programa Cura. 1986. Lima

CIBPU - Comissão Inte- Desenvolvimento de São Paulo, Imirestadual da Bacia Pa- gração Estrangeira e Nacional.1964. ranả-Uruguai

COGEP-PMSP - CoordenaPlanejamento Urbano em São Paulo. doria Geral de Planeja Série Políticas Globais n. 1. 1979. mento da Prefeitura Mu São Paulo.

nicipal de São Paulo

Idem

Estudos Básicos - PR 016 - Bela Vista - 28-010. 1974 .

Idem Projeto Grota da Bela Vista. 1974.

COGEP-PMSP - Coordena- Dossie - 038/12. Projeto 13 de doria Geral de Planeja Maio. 1975.

mento da Prefeitura do Município de São Paulo

CET - Companhia de Enge Boletim Técnicon. 1. nharia de Tráfego

EMPLASA - Empresa Metrọ Bens Culturais Arquitetônicos no politana do Planejamen- Município e Região Metropolitana to da Grande São Paulo de São Paulo. 1984. S/A e SEMPLA - Secreta ria Municipal de Plane jamento do Município de São Paulo 
JGEPAC - Inventátio Geros Bela Vista. Obra Inédita.

do Patrimonio Ambientas.

PMSP

Idem

Liberdade. Cardernos n. 2. 1986.

I dem

Aspectos Metodológicos. Cadernos n. 1. 1987 .

SEMPLA - Secretaria Muni- Dossie - 054/03. 1981.

cipal de Planejamento -

PMSP

Idem

Conheça sua Regiāo. Série Infor mações. 1985.

I dem

Coletânea das Leis e Decretos de Parcelamentos, Uso e Ocupa ção do Solo.

Idem

Plano Diretor de São Paulo. Governo Mario Covas. 1983.

Idem

Caderno de Mapas. Série Documen tos. 1985 .

Secretaria Municipal da

São Paulo Onde está sua Histó-

Cultura - DPH-PMSP ria? Masp. 1981.

Idem

Obras de Arte em Logradouro Públicos de São Paulo. Regional Sé. 1987.

Prefeitura Municipal de Plano Urbanístico Básico - PUB Sāo Paulo 1969. 
Monografias c Teses

ABL, Tomyuki André

ALESSANDRI CARLOS,

Ana Fani

LAGANA, Liliana

MERLINO, Maria Cláudia

Moreira

$\cos T A S \AA$, Cristina da

e outros
Metropolização e Planejamento Metropolitano. TGI - FAU - USP. 1975.

A (Re)produção do Espaço Urbano

o Caso de Cotia, Tese de Doutorado. FFLCH-USP, 1987.

O Sagrado e o Profano. Mimeogra fado. 1986.

A Experiência das ruas Jandaia e Assembléia como motivo para uma reflexão sobre a questão do Patrimônio Cultural e Ambiental Urbano. TGI-FAU-USP. 1987.

Bexiga. Monografia do curso de Pós Graduação. FAU-USP. Disci plina $\mathrm{AU}-708,1980$. 
Jornais

- Estado de São Paulo

I dem

Shopping-News-City

Idem

I dem

Idem

Folha de São Paulo

I dem

Gazeta de Pinheiros

DOM (Diārio Oficial do

Município-PMSP)
$14 / 07 / 87$

$31 / 08 / 87$

$30 / 08 / 87$

$19 / 06 / 87$

$17 / 07 / 88$

$30 / 10 / 88$

$15 / 04 / 74$

$10 / 12 / 74$

$08 / 07 / 88$

$10 / 12 / 87$ 
A digitalização deste documento foi possível graças ao investimento do Programa de Pós-graduação em Geografia Humana (PPGH-FFLCH-USP) e realizada com recursos da Coordenação de Aperfeiçoamento de Pessoal de Nível Superior - Brasil (CAPES) - Código de Financiamento 001. Essa ação integra as atividades de comemoração dos 50 anos do PPGH no ano de 2021. Para mais informações sobre o PPGH e sua história, visite a página do programa: http://ppgh.fflch.usp.br/.

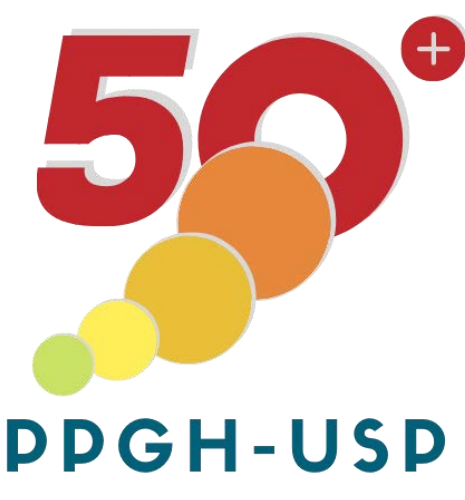

$1971-2021$ 